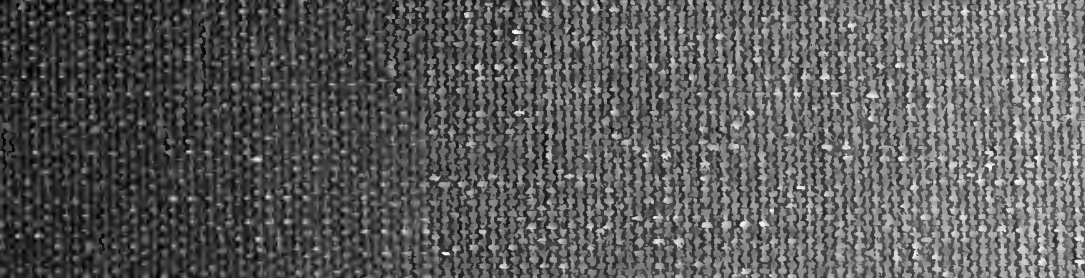

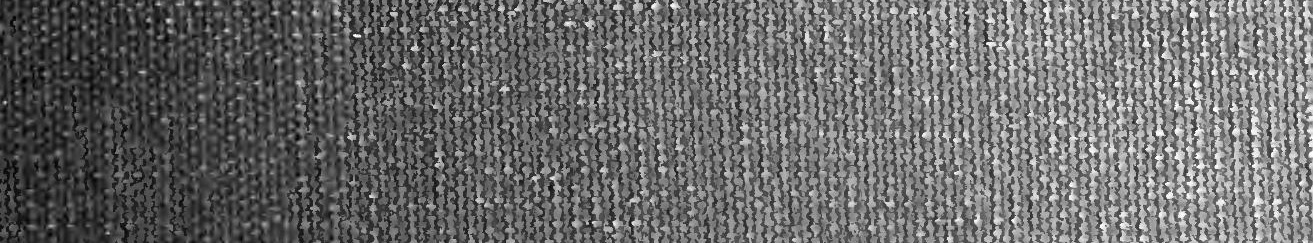
D)

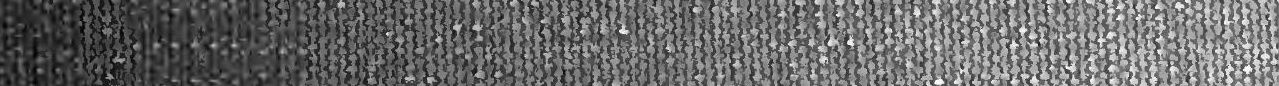
45.

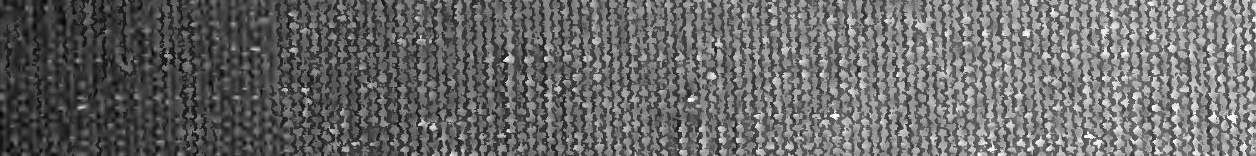
2850

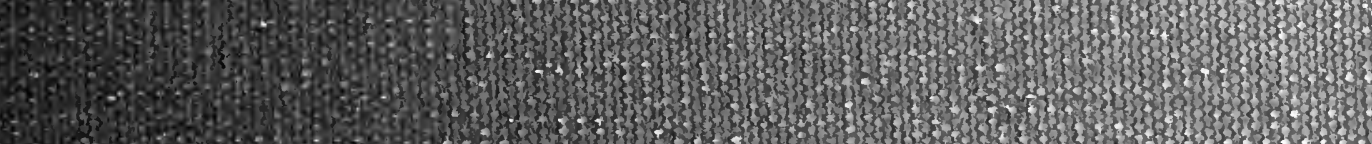

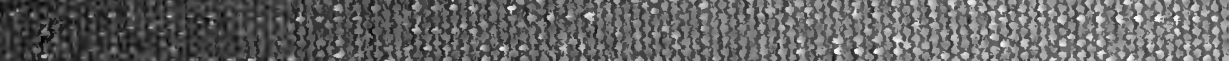
2.3.

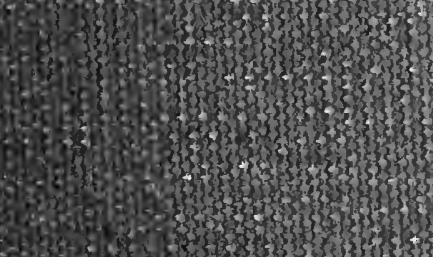
326

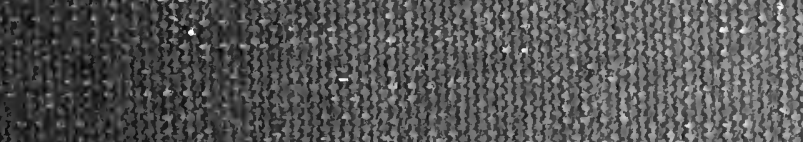
H. (3) 3. H. 13.

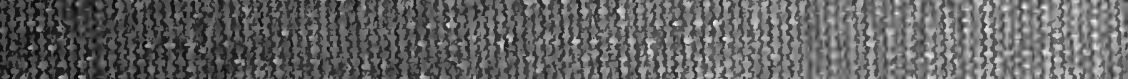
4.

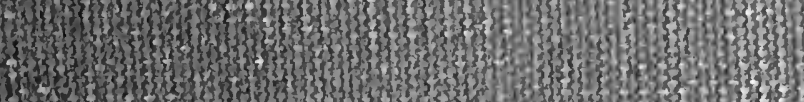
W. 3. Ty H. Ey

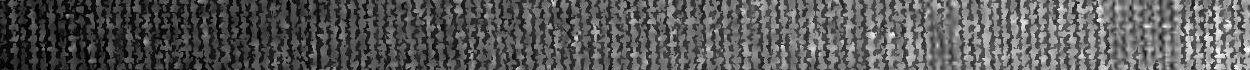
3 13. 


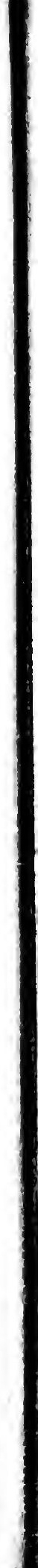








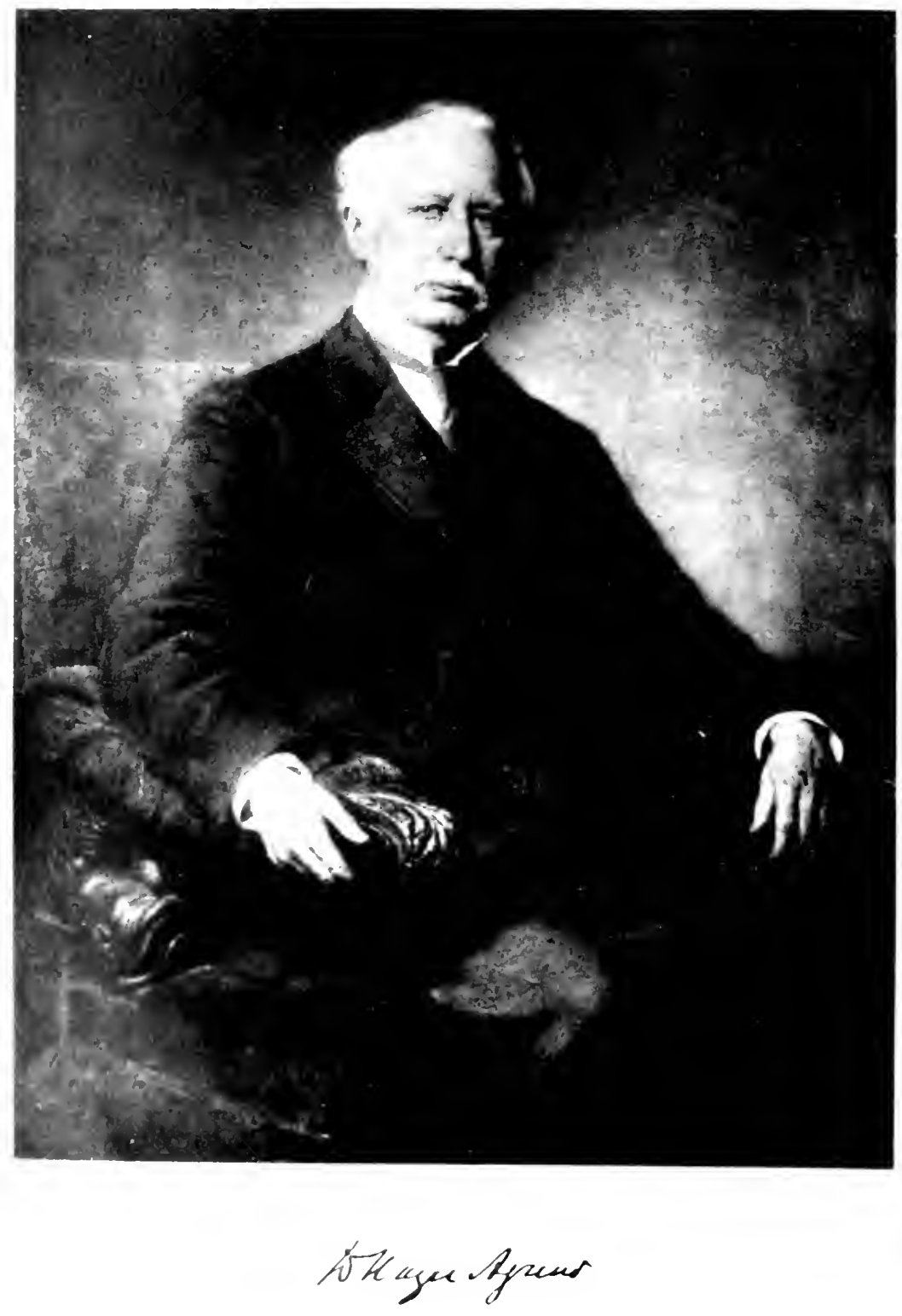




\section{HISTORY OF THE LIFE}

OF

D. HAYES AGNEW,

M.D., LL.D.

J. HOWE ADAMS, M.D.

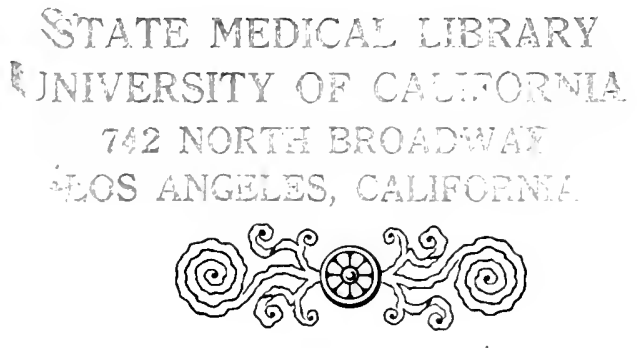

PHILADELPHIA AND LONDON:

THE F. A. DAVIS COMPANY, PUBLISHERS, I 892 . 
Copsright 1:92,

By J. HOWE AD.MS, MI.D.,

Philadelphia.

I phlatelitua, Pa, I C. A.

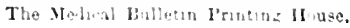
1:1ti Cherry street. 
characteristics which not only serve to consolidate the character and lead to success, but which, from their multiform points in which they come in contact with common lumanity, confer a personal interest in the life. The glory of the $A l p s$ does not consist merely in the mighty mountain-peaks which send their spires to heaven, clothed with sunshine and cloud; the foot-hills clustering at the mountain-base, the rippling streams, and pleasant meadows catch equally the eye of the pleasure-seeking tourist and increase the beauties above by contrast.

And so with Dr. Agnew: it was not alone those achievements which bore the stamp of originality, which heralded his name on the wings of the wind and made it a tower of strength which we have endearored to depict; but there were other charms of social and personal life which have made his memory fragrant in the minds of his friends. In endeavoring thus to show his life and its effect upon the American world, these lesser points have been included as far as possible.

If' any better conception, however shadowy and undecided, of the life, character, and accomplishments of this grandest figure in American medicine, can be gained from reading this biography, the writer will feel that the labor of love was not done in rain.

December $20,1892$. 


\section{CONTENTS.}

CHAP'TER I.

PAGE Lineage of THE AGNew Fanili, • • • • • • • •

CHAPTER II.

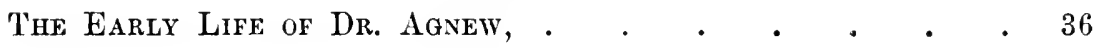

CHA PTER III.

The Story of Dr. Agnew's Business Venture, . . . . $\quad 60$

CHAP'TER IV.

Dr. Agnew's Connection with the Philadelphia School of

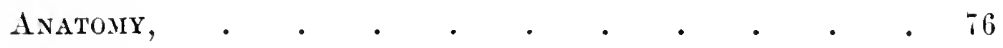

CHAPTER V.

Dr. Aanew's Early Life in Pinlladelpilia, • • • • • • 106

CHAPTER VI.

Dr. AGNew's Life from 1860 to 1870, . $\quad . \quad$ • . . . 128

CHA P'IER VII.

Dr. Agnew as Professor of Surgery, . • • • • • • 154

CHAP'TER VIII.

Dr. Agnew's Original Work in Surgery, • • • • • $\quad$ - 173

CHA P'TER IX.

Dr. Agnew as a Writer, . . . . . . . . . 193

CHAP'TER X.

I'he Garfield Case, . . . . . . • • • • . 220

CHAPTER XI.

Dr. Agnew's Hone-Life, • • • • • • • . 250 
vi

CONTENTS.

CHAPTER XII.

IR. AgNew's Later Life,

CIIAP'TER XIII.

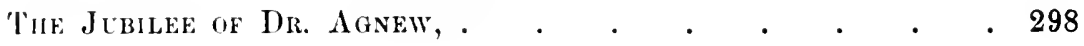

CHAPTER TIT.

1)r. Agnew's Retirement from the University of Pennsylvania, 318

CHAPTER XV.

I) Agnew's Final Sickness, Death, and Funeral, • • . 339

CHAPTER XVI.

Estimate of Dr. Agnew's Position in Surgery, . • . . 353

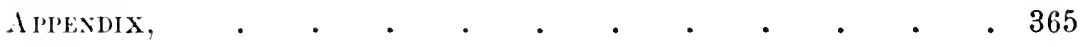




\section{LIST OF ILLUSTRATIONS.}

Uhle Portrait of Dr. Agnew, . . . . . Frontispiece

The Agnew Cont of Arms, . . . . . . . . Facing page 18

The Charcoal-House of the Pleasant Garden Iron-

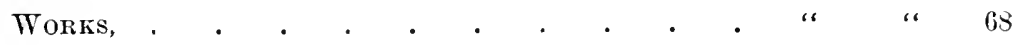

The Philadelphia School of Anatomy, . . . . “ “ “ 78

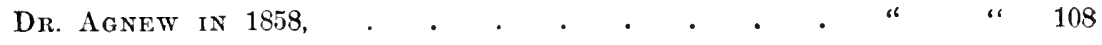

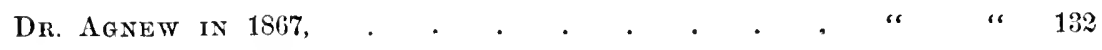

Fac-simle of Title-Page of Japanese Edition of

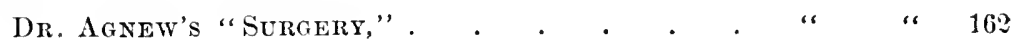

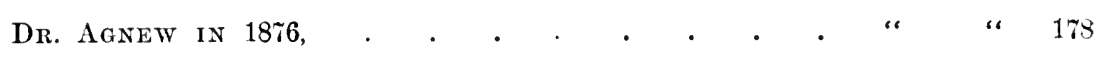

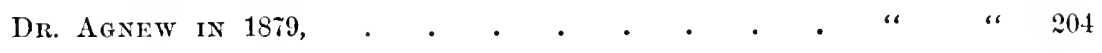

Dr. Agnew in 1882, • • • • • • • c c " c 280

Dr. AGNew in 1884 , • • • • • • • • “ "

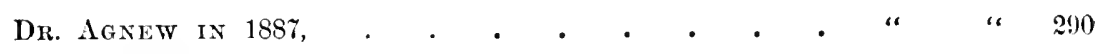

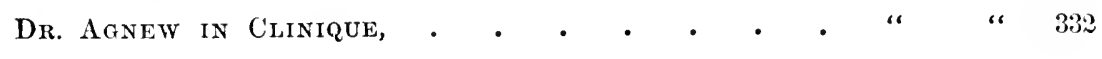

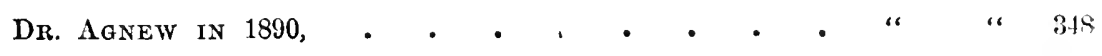




\section{CHAPTER I.}

\section{Lineage of the Agnew Fayily.}

THE earliest record of the Agnew family, which can be definitely and connectedly followed down to the present time, comes from Agneaux, a quaint little village in northern France, from which the family derives its name. This form of origin of surname is not unusual, for the most ancient and most honorable names found at present in Great Britain and Ireland are derived from the names of places in Normandy or in neighboring parts of France. In fact, there is no village in Normandy which has not given its name to some family in England. Genealogists have decided that this is the most common form of the derivation of English and Scottish surnames, exceeding those derived from occupations, mental characteristics, Christian names, and sobriquets.

It has further been conceded, that it was the universal custom for the place to give the name to the family, not the family to the place. This is the reverse of the process in America. In this country the family has invariably given the name to the place. The little town of Agnew in Lancaster County, Nebraska, named in honor of Dr. Agnew, is a typical example of this method. It shows the space of time which has elapsed, and the changes in living and cirilization, between the Agneaux of the old world and the Agnew of the newer continent.

The name Agneaux is Norman-French for "lamb," being derived, of course, originally, from the Latin term agnus, a word of the same signification. The variety of ways in which the name has been spelled is numerous, Agnean, Agneaux, Agneux, Aigneux, Aigneaux, Aignel; the Latinized forms are Agnelli, Agnella, Agnellus; the modernized forms are Agneu, Agnieu, and Agnew. The word "agneau" in French still bears its original signification of "lamb." 
The Normans. or Norsemen. as is well known, were not of French origin, but were bold. adventurons explorers from the north of Europe, who fell in great swarms upon the neighboring sca-board countries. seizing lands for their own use, and carrving death and destruction to the original inhabitants.

Agncanx, this little Norman town, which has been dead to the world for many centuries, holds, then, the honor of being the originating place of the ancient and honorable family of Agnew. Here was moulded into permanent form, this elamish family, which all the ricissitudes of rude and stormy times could not tear asunder. This place is still a village of less than 500 inlalitants. It stands solitary and unprogressive, far from the nearest raihroad station, although it seems unfair to compare such a quaint old place with such a modem creation as the railroad. It is not large or important enough to be found in the French gazotteers, and even a diligent search of maps in Paris fails to reveal its location. This quaint spot is large enough, howerer, to be goremed, according to French customs, by a maror. It is located in the Département de la Manche, near the city of Saint-Lo. The Department of Manche is on the northwestem coast of France, jutting into the English Channel; it derives its name from the French term for the English Channcl, "I a Manche." Its bold, mprotected position is just such an one open to the invasion of such hardy seamen as the Torsemen.

There still exi-ts in Agneaux an ancient chateau, belonging to the Marequic de ste. Marie d'Agneanx, which was quite capable of resiting a siege. Aromud the memory of this ancient castle many of the romantic lengends of Normandy have been woren. At the time when the Huguenots were driven from France. during the reigns of IJenri III and Henri IV, this cattle formed me of the headquarters for the Protestants. The scion of this anrient family espoused this religion, and threw all his resoures to the defome of its adherents.

The names of Agneanx and Aigneaux are not uncommon 
in this region, although there has been a general exodus from this country in the past eight hundred years.

The explanation of this exodus of the Agneaux from Normandy is seen in studying the history of the family. Family tradition reports that at the time of the Norman conquest of England by William the Conqueror, in the eleventh century, the chief body of the family came with him, settling in England and Scotland. This was an age of rough manners and brutal conquest, and it required the banding together of large bodies of well-built, courageous men to survive. Some of the family, filled with this restless spirit of conquest which was the feature of the age, did not linger in Great Britain, but followed "Strong Bow," Richard de Clare, Earl of Strigul, to Ireland, rendering efficient aid to him in the conquest of this island, in the twelfth century.

A further element which assisted in driving the Agneaux who remained in France after the Norman conquest from their native spot is explained in an exhaustive work entitled "Protestant Exiles from France in the Reign of Louis XIV, or the Huguenots and their Descendants in Great Britain and Ireland," by the Rev. David C. A. Agnew. This work, which includes a complete list of all the families which comprised this religious body joining in the exodus, shows that many of the Agneaux who were left behind at the time of the Norman conquest became Huguenots at the time of the Reformation.

The Agneaux were moderately numerons in France from the ninth to the sixteenth centuries. As early as the tenth century, knights of this name swelled the ranks of French chivalry and aequired landed estates in several French provinces; their heraldic achierements are to be found recorded in the rolls of the ancient nobility of Normandy, Burgundy, and Provençe. The first member of the family whose name is definitely known, Agneaux de l'Isle, lived in the neighborhood of Caen, in the arondissement of Bayeux. He was Lord of l'Isle and Auval, his heraldic bearing being Three Holy Lambs, on 
an azure shield. Ile was also entitled to carry "two bars vert on a golden shield surrounded by an orle of martlets" as Lord of Auval. This latter achievement, carried first as an addition, was soon afterward adopted, in place of the original bearing of the family, by his descendants, - these gentlemen probably considering the Holy Lamb as too peaceful an emblem for such restless adrenturers.

From Agneaux de l'Isle sprang various families, all of which prospered,-four of which held scignorial fiefs in Normandy, a fifth in Burgundy, and a sixth branch in Provençe.

Sir Philip d'Agneanx, the heir of line of the senior branch, was created a banneret, for military services, in 1228; his father and uncle were already knights. Sir John d'Agneaux was one of the companions of de Harcourt, Admiral of France, in a voyage which he undertook in 1295; while in the Book of Achievements, drawn up by command of Charles $\mathrm{V}$ of France, in 1368, a Sir Fulke and a Sir William d'Agneaux are both honorably mentioned. An offshoot of the same stem, Agneaux, Lord of Alencourt, adopted as his arms "three crescent gules, upon a shield of gold." Both these crescents and the martlets are special indications of good scrvice done against the infidels, or of long royages of discovery and adrenture.

The line of the Alencourts ended in an heiress; she gave her name, however, to her descendants, and this branch of the family is styled Ste. Marie d'Agneaux. These Agneaux are traced for many generations in the "Armorial de France." Jean Jarpues Renè de Ste. Marie d'Agneaux, of this branch of the family, was famons during the reign of Louis $\mathrm{XV}$.

IIistory reports that a number of the members of the family who remained in Normandy after the Norman conquest gained distinction in other ways. Robert and Antoine Agneaux, or, as the name was then written, Aigneaux, born in Normandy in the sixtcenth century, translated "Virgil" into French in 1582. This work became popular, and stands even to-day as one of the great landmarks among the translations of the Middle Ages. 
The chief interest centres, however, in that branch of the Agnew family which settled in Scotland. It was in County Wigtown, in southwest Scotland, which juts with bold outline into the North Channel and the Irish Sea, that the principal branch of this bold, adventurous family finally settled. Here, in the wild and unsettled times of the early part of the history of 'Scotland, they held their own, and became prominent in that country at a time when great physical development was as necessary for existence as shrewdness and intelligence. The records of the time show that as early as the year 1330 they became the holders of the office of Hereditary Sheriff of County Wigtown. "The Sheriff of Wigtown" was the title of their office; yet in royal proclamations and even in acts of Parliament, and always in familiar intercourse, this official was addressed as "Sheriff of Galloway," the name of Galloway being. applied to the comnties of Wigtown and Kirkcudbright.

This office formed the very backbone of the feudal system; it was held in the Agnew family, despite all the various changes through the Middle Ages, for more than four hundred years, until the abolishment of hereditary jurisdictions in Scotland, in 1747. The abolition of this office-the removal of the last trace of the government of the Middle Ages-was the final blow struck at the feudal system. As a compensation to the Agnew family for the loss of this hereditary office, they were paid by the English government the sum of $£ 4000$.

The duties of an hereditary sheriff in Scotland were far more important than are commonly associated in these later days with the office of sheriff. Next to the king, the sheriff of that day was the most powerful individual in the land. On the performance of his duties rested the foundations of society; he was law, lawyer, judge, jury, and executioner of penalties. He owned allegiance and submission only to the ling. This officer, unchecked by nearly all restraints, was not as oppressive and tyrannical as might be inferred from his powers. In medieval times those at the fomntain-head of authority were the least 
inclined to be unjust and arbitrary. It was the resident owners of the soil who were the source of greatest oppression to the people.

The essence of feudalism was, that superior and rassal were alike bound together by ties of reciprocal good-will. "Gentleman's law," even to this day, is regarded respectfully by the pealsints of Scotland. This absolute power of the sheriff can be estimated, when it is realized that even an earl in those days had not the power of shrievalty within his own earldom. In ancient times an appeal lay from the judgment of the earl, as proprictor, to the court of the sheriff.

It is at Lochuaw, Stramraer, Scotland, that the Agnew family holds its castle, the present incumbent of the title being. the twenty-first in descent from the first Agnew who settled there.

Although some of the Anneaux family came over to Fingland during the reign of William the Conqueror, nothing definite of their doings is known. 'The first Agneaux of whom any anthentic record exists in Great Britain is that Agneaux de l'isle who took part in the conquest of Ulster, in the reign of IIenry II of Eugland, in 1171. For lis services in this conquest, he was allotted the Lordship of Larne, a beautiful spot on the northeastern coast of Ireland, with a view which was teminated only by the distant Scottish coast. In commemoration of the expedition in which they had gained their new possesions, "the sinister hand of Ulster" was introduced into their shiell. 'Their name was also given to the highest momtain in the Antrim range, which still retains its appellation "Agnnw's IIill."

Ilere this fimily of bold adventurers remained for more than one humderel yoars, and the descendants of the Lord of Larne in the fifth enencration were in quict possession of the land he hat arequired. At the commencement of the fourteenth century the lord of lanne, in common with his neighbors, was impatient of the English yoke. The English monarchs were looked upon rather as feudal superiors than as lings; indeed, 
they hardly assumed the latter title at this period. The Ulster lords wished to assert their entire independence, and have a king of their own. Hearing of the doughty deeds of Edward Bruce, brother of King Robert Bruce, across the chamnel, they offered to acknowledge him as their sovereign if he would undertake to bring them armed assistance and put himself at their head.

The restless Edward was delighted with a proposal so congenial to his tastes; and, organizing what forces he could in Galloway, he landed, with six thousand men, at Olderfleet Castle, the property of the Agnews, - the ruins of which may still be seen, - on the Lough of Larne, in 1315. Here the Lord of Larne and his retainers received him with great joy, and all the lords of Ulster, hearing of his arrival, flocked to his standard. In 1316 Bruce was crowned King of Ireland.

At this time the good King Robert Bruce lived at Lochnaw, in the castle which had been erected a century before. This was his own garrison, and there was no other fortress as suitable in respect to position, for the old castle was considered impregnable, commanding fine views of the Firth of Clyde and the opposite Irish coast, Agnew's Hill being a prominent feature in the background. Robert followed his brother Edward to Ireland, and together they adranced as far as Dublin. 'Two years later Edward Bruce was killed in battle, the English again came into supremacy, and the remmant of the Scottish army retreated to Scotland.

The Lord of Lame had been so seriously compromised with the English authorities, by this connection with the Bruces, that we are not surprised to learn that his sou and heir appeared at the Scottish court after the death of Robert Bruce, when the Earl of Moray, his old commanding officer, was chosen liegent during the minority of King David II. As a reward for his past services, and to hold his allegiance in the future, the young Lord of Larne was installed in the kecping of the office of Constable of Lochnaw.

The young constable showing bravery and spirit,-qualities 
necessary for an officer holding the king's commission among the wild scots of Galloway,-was soon afterward appointed Sheriff of Wigtown. The sheriffship is described as an hereditary gift, but the successions were not preserved at this time; for the Earl 1)ouglas, in a later generation, forcibly denuded the Agnews of their office for some years. Hence the appointment of the first three sheriffs is regarded as personal; the office of Hereditary Sheriff of Wigtown being given again to the Agnews in a new charter, in 1452. It was only this latter commission which was recognized by the English government.

This is the historical story of the first settlement of the Agnews in Scotland; but the traditionary account, which is fully believed by the oldest inhabitants, points to a much bolder course, by which the Lord of Lame obtained a footing here.

According to this tradition among the peasantry of Wigtown, a member of the Agnew family once found himself in Galloway, and here he determined to stay; and, courting adrenture in the true Norman spirit, he cast his eyes about him for a well-housed foe. The king's Castle of Lochnaw, according to our informants, had been captured by one M'Clellan, a chief of the native race; and here, strongly posted in the fortress, he set the royal anthority at defiance. The castle was quite to young Agnew's taste, and he immediately besieged it, with the full alprobation of the king.

M'Clellan was well armed and provisioned, and Agnew, with a small hand of followers, could make no impression; hence, storming the castle was out of the question, and he was compelled to resort to strategy. It must be understood that the castle stood on an island. and, with the exception of a narrow rock at either coll, the ground was entirely covered with the buildiness of this fortress.

Annew withlrew the besieging party from sight, and it was settled that his right-hand man should be hanged on a tree, the rope being so arrangerl that the victim could himself prevent strangulition. The hanging seene was duly enacted, and 
the executioners retired. The plot succeeded to their hearts' content. M'Clellan had watched their strange doings, and no sooner saw them off than, manning a boat, he rowed to the shore to see what had been done. No sooner had he landed than out rushed the besiegers from an ambush. I'Clellan's retreat to the island was instantly cut off; but he and his band fought their way out of the inclosure. Agnew followed him, and, when they reached the site of the Brig O'Doon, he succeeded in dispatching the old chieftain. Now, in the moment of triumph, he remembered, for the first time, his poor, half-hung lieutenant. When he arrived again on the shores of the white Loch of Lochmaw, there the poor decoy hung, stiff and colr.

On the death of the Bruces a civil war broke out, and in $134 \tau$ David II was taken prisoner by the English, and the Sheriff of Wigtown would have been destroyed had not Sir William Douglas come to his relief. A story of ravage and confiscation follows this erent,-for a century the country was untilled, the woods were wasted, and the forester's art was utterly neglected.

The Douglases had always been friendly to the Agnews, but in 1390, Black IDouglas, a natural son of the famous Earl Douglas, rose into power. He determined to reduce all the Scottish barons to a state of rassalage. The Constable of Lochnaw could offer no serious resistance to the forces of the earl, who besieged the Castle of Lochnaw. Erentually the Agnews were driven from Scotland, and sorrowfully the Laird of Lochnaw, the great-grandson of the first proprictor, sailed, with his family and retainers, across the channel to the Bay of Larne. In the words of Sir George Mackenzie, a chronicler of the period, "the Castell of Lochnaw was blowen up." This act of Black Douglas was extremely bold, for the castle was still the property of the king.

The ex-Constable of Lochnaw found Ireland little to his liking, and repaired shortly to the Scottish court at Perth, where he received from the aged monarch, Robert III, much commis- 
eration. but no assistance. He became a member of the royal honschold, and stood in high faror. While at court the young Annew had the good fortune to attract the farorable notice of l'rincess Margaret, who was married to Archibald, son of Black Douglas. Although not inclined to love the name of Jonglas, yet he soon had cause to be grateful for her good offices. On the death of her husband, she received from her brother, King James I, the lordship of Galloway, and she took up her residence with fendal pomp at the old Castle of Threave. Here she was accompanied by her young motégé, Andrew Agnew.

'Through her efforts Andrew Agnew was restored to the possessions of his fathers, in 1426 , on his marriage to Princess Mary. the niece of his liege lady.

'The old castle had been destroyed by Black Douglas, and the constable set bravely to work to build a better home for himself and his gentle bride. On the south shore of the Loch of Lochnaw he built a castle, a greater part of which stands to the present day, which, as has been said, is still owned by the. Annews, his lineal descendants.

In a "Iistory of the I Iereditary Sheriffs of Galloway," by Sir Indrew Ignew, Bart., M.P., there is a fine picture of Scotti-h life from the year 1170 to $174 \%$. Sir Andrew Agnew has compiled this book from the archives of the Agnew family, including sasines, infeftments, summonses, discharges, letters of horning, inhibitions, informations, bonds, precepts of clareconstal, marriage contracts, reliefs, wills, tacks, commissions, rentals, alcts of Parliament, processes and all sorts of papers connerted with the procedings of the Sheriff Courts; memo-

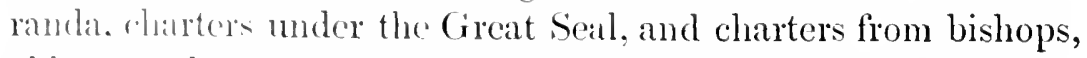
abbot.. and commendators. In this way the actual picture of sicottish life throughout this period has been depicted; the customs. the dreses. the value of money, the price of the necessaries of life. the food caten, table manners, the rentals paid and received, and all the minutie of Scottish life have been drawn, 
making the book an invaluable treasure-house for the antiquarian or the novelist, especially as the greater part of this matter has never been published in any other form.

Patrick Agnew, the fourth hereditary sheriff. may be taken as a fair type of a Scottish hereditary official in 1500 . As to law, he troubled himself little with studying the statutes. C'ustom was law to him, and he was not serupulous in enforcing his supposed rights, in definnce of any acts of Parliament to the contrary. If an injury was to be redressed or a friend to be assisted, he sprang into his saddle and dealt out justice with his own good sword, caring little for the technicalities; if attacked, he was ready to defend himself; if his cattle were carried off, he was quite capable of returning the compliment with interest. Such assertions of the dignity of his office he, doubtless, considered necessary to sustain the traditionary status of a Galloway sheriff.

Through Margaret Kennedy, the wife of Sir Patrick Agnew, the eighth hereditary sheriff, the Innews have a double royal descent,-on one side from King Jimes II of Scotland, and on the other from King Henry VII of England.

Sir Andrew Agnew, the twelfth and last hereditary sheriff, was a famous soldier, but not a practical agriculturist. On the death of his father. when the paternal estates fell into his possession, he determined to acquaint himself with the routine of farming opcrations. One of his attempts at such superintendence is the subject of a farorite Galloway story, which is still extant:-

"Sir Andrew, though a grand soldier. was nae farmer ava'; he kent naething aboot it. I' the castle form-wark in his days, an' lang before and after, was done by baillic wark. There was baillie plenching, baillie harrowing. baillie shearing, baillie cornleading,-aye, an' peat-leading. too! 'The tenants were a' warned in their turn to do as they were bun' in their tacks.

"Sir Andrew was new come hime; they had been a' warned in, and were slearing ower in the Beef-Park, an', as 
was alye the case when a wheen o' farmers met, they had great strivings wha wad be first oot at the lan's end. Horrid bad wark they made it, and whiles left as muckle as they took.

- Just as the sheriff came oot to sce, they were kemping ${ }^{1}$ a' they could, and the grieve, afeared the sheriff wad be angry, began and trod doon the lang stubbles wi' his feet, and made a show o' gathering as muckle o' the left corn as he could.

“ What's that ye're doing there?' says Sir Andrew, sharply.

“'Oh, please your honour,' answers the grieve, terribly frightened; 'oh, I'm just tramping doon a lot o' the o'erplus. There's plenty to tak' and plenty to leave here, please your honour. It's just to keep the grun' warm, your honour, for I expect a right guid awal crap here next year'; and so he ran on, searce linowing what he said."

Greatly astonished was the grieve to find that his ridiculous invention was taken in good faith; but if he felt little compunction at thus shamefully imposing upon his master, his deceit drew upon him a retribution as sharp as it was unexpected ; for the sheriff, greatly pleased with the theory of keeping the ground warm, "kecpit him there a' the morning, aye treading doon the stubble, and whiles he wad begin and tread doon the com himsel"." So the unjust steward cut a very sorry figure in the eyes of his own men. "Ye see," as is a usual remark after some similar stories, "although Sir Andrew wats a bra' warrior, he didna ken the lea-side o' a rick!"

'This Sir Andrew Agnew, on account of his daring military expleits and quaint humor, has become a famous figure in Scotch hi-tory. In his defense of Blair Castle from the attack of the rebels. in the spring of $17+5$. Sir Andrew was the hero of a number of characteristic incidents, which have been described by rir Walter scott in his "IIistory of Scotland." The

${ }^{1}$ Komping is an cxpresion commonly applied to reapers trying to see who will cut most quiclily their share of com in the harvest-field. While the term strictly signifies rivalry, it implies undue haste, and that the work is hurriedly and badly done. 
fame of Sir Andrew was already considerable, and the treatment which the rebels experienced at his hands went far to increase this reputation.

The rebels besieged this castle for a fortnight, during which time the sheriff showed himself too good a soldier to abandon his post, - although his men were in a state of semistarvation,-and he was too old an one to be provoked into a sally. He knew that each day he could detain so large a force of rebels before Blair Castle would be of the greatest advantage to the king; and here he determined to stay as long as a single mouthful of biscuit remained in store.

Time, however, hung very heavily the while on the hands of the younger officers, who, in default of all other sources of diversion, at last bethought themselves of a joke at the expense of their commander. As a part of the plot, they purloined a portion of the great man's wardrobe,-taking a full suit of the brigadier's uniform,--with which, with the assistance of some straw, they soon produced an excellent imitation of his figure. Then they placed the stuffed sheriff at a window of the tower, with a spy-glass in his hand, in the attitude of reconnoitering the rebels.

"This apparition," says Sir Walter Scott, " did not escape the hawks' eyes of the Highlanders, who commenced to pour their fire upon the turret-window, without producing any ade quate result. The best deer-stalkers of Athole and Badenoch persevered, nevertheless, and wasted their ammunition in rain upon this impassible commander. At length, Sir Andrew himself became anxious to know what could possibly induce so constant a fire upon that particular point; and ascending the turret himself, there he saw his other identity standing under fire,-as stiff, as fearless, as imperturbable as limself. The sheriff was scandalized at the imeverent deception, and, discorering the author of the plot, he delivered sentence upon the culprit to this effect:-

" 'Let the loon that set it up just go up himsel' and tak' it 
doon arain.' I wheat effect had been produced, however, upon the rebels, and the chansmen. already predisposed to regard the sheriff with smperstitious awe, had fomd their surmises as to his invulnerability so thoroughly confirmed that henceforth they becante hopeless of success."

I few days later, the sheriff was relieved from his unenviable position by the appearance of the king's Black Horse.

A camp-story, in which Sir Andrew did not come out victor, has heen preserved of these days, to understand which it is necessary to bear in mind that, in the Lowlands of Scotlind, a "Lammermuir lion" is a proverbial expression for a sheep.

After the affirir at Ostend, in which Sir Andrew Agnew distinguished himself. when the English were at war with the French, the officers of the garrison were talking over the incidents of the siege at the dinner-table, and, becoming very noisy as they fought their battles over again, some of the younger ones became very cloquent on their own prowess, until the Commandant, sir Andrew Annew, becoming tired, thought it time to give them a hint. Behind his chair stood a faithful serrant, a Lammermoor mam, almost as great a character as his master, who had followed Sir Andrew closely in many a field. "Jolun," said the sheriff, slyly," I think I looked as bold a man yesterday as any in the brigade; what do you say, my man?" "Are, sir Andrew," answered the batman, with a twinkle in his "ye, "you looked for all the world just like a lion!" An uproarious burst of merriment grected this response, in which the sheriff heartily joined. supposing it was due to his own wit at the experine of his officers. 'The tables, however, were soon turned; forl, ats he good-humoredly continned, "And wherever dicl !fon see a lion. ! w scoundrel?" a jolly young subaltern interpeard, " Oh, sir! there's plenty of lions in John's country ; surely you lnow John's liain many a Lammermuir lion!"

The General James Annew who was killed at the Battle of Germantown, Philadelphia, was a nephew of this sheriff. 
In 1775 he was made Aide-de-camp to the king, with the rank of Colonel, being made Brigadier-General the following year. The description given of his death in IIolmes' "Ammals of America " and in the "Pictorial History of England" is incorrect. The correct account is given on another page of this biography.

This sheriff's sayings and doings lave been the subject of innumerable traditions; "to give one of Sir Andreu Agnew's broad hints" has been a proverbial expression in Scotland for the last hundred years, the force of which is exemplified by a story from a book of Scotch humor, published toward the close of the last century :-

"Sir Andrew Agnew, of Lochmaw, a well-known Scotch baronet, was famous for giving what he called 'broad hints.' Having been long pestered by an impertinent intruder, it was one day remarked to the baronet that he was fortunate in having freed himself of the bore, and he was asked how he had contrived it. 'Alı!' he replied, 'I was obliged to give the loon a broad hint.' 'A broad hint!' said the friend; 'why, I thought he was one of those who would never take any hint!' 'By my faith,' rejoined Sir Andrew, 'but he was forced to take it; for, as the chiel wouldna gang oot at the door, I just threw him oot at the window.'"

He had been bred in the true old British prejudice against the French, and, although he had served often upon French soil, he hated the language, and disclained to learn a word of it. Once, when on a visit to his daughter, Lady Bruce, being at church, the minister, in his discourse, objected to the anthorized translation of the text upon which he was preaching, and gave an amended version, in enforcing the superiority of which he proceeded to say: "The words in the original Hebrew are these: Comment vous portez cous." The sheriff's wrath was raised to boiling-pitch; not only had an insult been offered to his understanding, but his peculiar antipathy had been aroused. He started from his seat, and it was with difficulty that he was persuaded by lis daughter to sit still. No sooner, however, 
was the service over, than his righteous indignation was brought out before all the congregation. "The scoundrel!" he said; "and yot, I could have forgiven him had he not used the only French I ever knew."

Following the rebellion in Scotland in 1746, the British government, alarmed by its extent, were naturally anxious to increase the influence of the Crown in Scotland; the great barrier to the accomplishment of this purpose was the hereditable jurisdictions held by the barons and chieftains.

As these hereditary rights had been expressly reserved at the time of the mion of England and Scotland, it was feared that their abolition would breed fresh dissatisfaction; but after a fierce battle over the subject in Parliament, a bill was passed abolishing hereditable jurisdictions and making arrangements for compensation to their owners.

It was found that in only sixteen cases the claims of hereditary sheriffs could be proved, viz, those of the shires of Argyle, Bute, Caithess, Clackmannan, Cromarty, Dumfries, Dumbarton, Elgin, Fife, Kinross, Kirkcudbright, Nairn, Orkney and Zetland, Peebles, Selkirk, and Wigtown.

In only four families had the sheriffships of their respective counties been continuous since $156 \%$. These were:-

The Earls and Dukes of Argyle, .

The Farls of Rothes,

Tarbert and Argyle.

The Murrays of Philiphagh, .

The Annews of Lochnaw, Fife.

Selkirk.

Wigtown.

Of these, the Duke of Argyle's commission was dated February 26, 1+7.3; the Farl of Rothes', June 1, 1529; the Murray"s is mknown; while the Ignew's was dated 1452 , making it the oldest in Sicotland, although, as has been shown, the Agnews held the office for over a century before that date. 'The sheriff of Wigtown rlaimed less proportionally than any of the other office-holders, and received $£ 4771$ 6s., being nearly six times as murh as all of the rest collectively, showing that his office was considered of the greatest importance. 
Thus ended the days of hereditable jurisdictions in Scotland. No rational person can now doubt that the change was a wise one, although this conviction grew only gradually upon the people.

This Scottish branch, which had long held the title of Knight, were given a baronetage on July 28, 1629, by Charles I. The circumstances under which the Agnew family received its baronetage forms an interesting page in English history. This title was not regarded by the Agnew family at the time as conferring any special dignity to their position, and they preferred the title of "Sheriff" to that of "Sir." Different members of the family had been knighted many times by different sovereigns, but they had not used their titles. It was not until later years that this title grew into greater prominence.

The title of baronet is of comparatively recent origin, having been revived by King James I, who constituted it an hereditary dignity. The term "baronet" was originally given to a class of bannarets, who were hereditary barons of Parliament. The existing baronetage of England dates from 1611, in which year James I established it by letters patent under the Great Seal ; in 1619 he further extended the order to Ireland, and in 1624 adopted steps to create a Scottish branch, which intention was carried out, in 1625 , by his son Charles I.

Every person who sought the dignity of a baronet was compelled to give proof that he was a gentleman of blood,-i.e., descended on his father's side from a grandfather who bore arms, possessed of a good reputation, and had an ammual revenue of not less than $£ 1000$.

These baronets, in turn for the honor granted them by their government, were expected to help in return in maintaining armies in different localities. Thus, the baronets of Ulster assisted the government in its management of afficirs in Ireland; the baronets of Nova Scotia, among whom were the Agnews, rendered great aid in colonizing that recently-explored region. These latter baronets were granted special honors by Charles I, 
being permitted to wear around the neck "an orange taunie silk ribbon, whereon shall be pendent in a scutcheon argent, a saltier azure, thereon an inescutcheon of the armes of Scotland, with an imperial crown above the scutcheon, and encircled with this motto :-

\section{"Fax mentis honesta gloria."}

The Hereditary Sheriffs of Galloway from 1452 to 1629 were as follow: Andrew, Andrew, Quentin, Patrick, Andrew, Patrick (who was the first of his race to be buried as a Protestant, in 1590), Andrew, and Patrick Agnew.

It was this last Sir Patrick Agnew, Knt., who was created a Baronet of Nora Scotia on July 28, 1629, by Charles I. He married Margaret, daughter of Sir Thomas Kennedy, and died in 1661. His son, Sir Andrew Agnew, MI.P. for Wigtownshire, was appointed, on the suppression of hereditable jurisdictions, by Cromwell, in 1656, Sheriff of all Galloway, and a member of the Commission for governing the Kingdom of Scotland. At the restoration of Charles II, he was re-instated in his hereditary sheriffilty, in 1661. Sir Andrew married Lady Anne Stewart, daughter of Alexander, Earl of Galloway, and dicd in 16r1. His son and heir, also named Sir Andrew Agnew, on refusing the test oath of 1682 , was ejected, by the Privy Council of Scotlind, from his office, but was re-instated at the restoration, in 1689, by the Convention of Estates, of which he was a member. IIe married Jane, daughter of Sir Thomas Hay, lianonet of Park, and died in 1701. His son, the fourth baronet, Sir James Agnew, married Lady Mary Montgomerie, daughter of Alexander, Earl of Eglinton. He is particularly famous in history for being the father of twenty-one children.

The fifth baronet, Sir Andrew Agnew, was the distingruished militury officer of whom we have already read, being a Lientenant-General in the English army. During his lifetime, hereditary jurisdictions were abolished finally in Scotland. He had married his consin, Eleanor, the only daughter of Thomas Agnew, Esq., and was also remarkable in being 


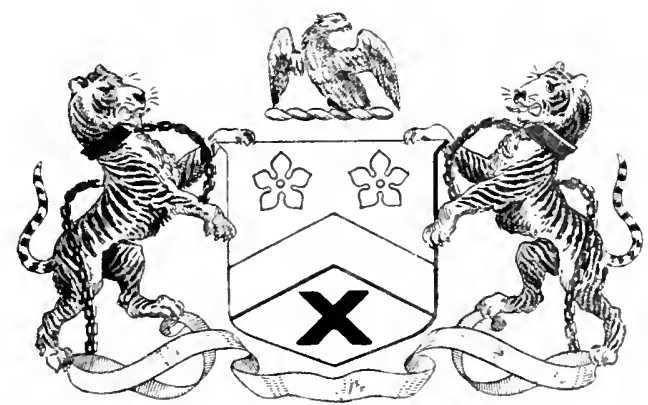

THe Agnew COAT of Arms. 
the father of eighteen children. He died in 1771, at the advanced age of $8+$ years, being succeeded by his fifth but eldest surviving son. Sir Stair Agnew, his son, sixth baronet, married Mary, daughter of Thomas Baillie, Esq. On account of the death of his eldest son, Andrew, who had married Martha De Courcy, eldest daughter of John, twenty-sixth Lord of Kinsale, he was succeeded by his grandson, Andrew, a posthumous ehild. The seventh baronet, Sir Andrew Agnew, married Madeline, daughter of the late Sir David Carnegie, and died in 1849. He was succeeded by Sir Andrew Agnew, who married Lady Louisa Noel, daughter of Charles, Earl of Gainsborough. The life of this baronet forms a remarkable coincidence with the head of the American branch of the Agnew family, for he was born in 1818, the same year as Dr. D. Hayes Agnew, and died March 25, 1892, three days after Dr. Agnew's death.

The present incumbent of the title, Sir Andrew Noel Agnew, was bom in 1850. He married Gertrude, daughter of the Hon. Gowran Charles Vernon.

The coat of arms of the Agnew family is as follows:Arms, argent, a chevron between two einquefoils in chief, gules, and a saltier couped in base, azare.

Crest, an eagle issuant and regardant, proper.

Supporters, two heraldic tigers, proper, collared and chained, or. Motto, "Consilio, non impetu,"-by persuasion, rather than by force.

Seat, Lochnaw Castle, Stranraer, Wigtownshire.

Anciently the coat of arms was azure, three lambs passant, argent, with the motto "Agnus Miles."

Of those members of the Agnew family who migrated to America from the North of Ireland the greater number came originally from Scotland, becoming members of that brave, hardy, persevering, and Godly race, the Scotch-Irish. The earls of Tyrone and Tyrconnel, in the Prorince of Ulster, having conspired against the government, in the reign of James I, fled from the kingdom to escape punishment. Some of their accomplices were arrested, condemned, and executed, but the 
two carls were attainted by the process of outlawry, upon which their vast estates, containing about five hundred thousand aeres of land, were escheated to the crown. King James resolved, if possible, to improve a country which was covered by forests, desolated by war, infested by robbers, or inhabited by ignorant natives. For this purpose he divided the escheated linds into small tracts, and these he gave to colonists, who were to settle them within four years with a certain number of subtenants.

According to his command, in 1610, the preference was given, in distributing the lands, to the inhabitants of the west of Scotland, as they were Protestants from his own country and were industrious people. The passage by water being very short, they conld with greater ease settle the land according to their contracts. The establishment of prelacy in Scotland in the year 1637 and afterward in the year 1661, among people who had adopted the simpler form of Presbyterian worship, became additional cause of the numerous emigrations from that kingdom to the North of Ireland.

The superior knowledge, industry, and temperance of the Scotch in a short time cnabled them to supplant the natives among whom they lived, and six of the northern counties, by the end of the seventeenth century, were inhabited chiefly by the descendants of Scottish families or the remuants of Cromwell's army. Their faithful services and uniform attachment to grovernment had placed them in the ranks of good and faithful subjects, and their unshaken loyalty had entitled them to confidence and public favor; but they were treated like aliens and strangers by Charles II and James II, with marks of distrust for their civil capacity, and depressed in their religious observances by the spirit of intolerance. because they were not of the establiched Church of Ireland. Men who were thus degraded and rexed by burdens and slights emigrated in thousands to Pennsyliania, where they knew the principles of civil and religious liberty had their full operation. 
Among this rare people stood prominently the Agnews. This class of people, who had reclaimed the desolated lands of Ulster, who had built towns and established manufactories, were Presbyterians; and neither the tyranny of Charles II nor James II, the dragoons of Claverhouse nor the intimidations of the Papacy, could compel them to surrender their independence or give up their religion. These were the people who had made famous the glens and moors of Scotland and Ireland, and who, rather than yield their convictions of faith and duty, suffered the sharpest persecutions, coming eventually to this side of the Atlantic Ocean to find homes more congenial to their taste. Men of strong intellect, independent thinkers, intolerant of oppression, gentle in peace, but terrible in war, they have left their impress upon all the institutions of the country of their adoption.

The bold position of County Wigtown, and the fact that the family were engaged in the colonization of one of the largest and most important of the American colonies, also naturally attracted the attention of the members of the family to America. In consequence, in the early part of the history of this country the Agnews became prominent. In the early part of the eighteenth century, three brothers of this firmily came to the then British colonies. One brother settled in New Jersey, another in Pennsylvania, and the third in South Carolina. The name of the brother who settled in South Carolina was Samuel. His descendants are still in existence in the South, a number of the family living in Mississippi, forming the branch of the "Southern Agnews." During the Revolution, the members of this branch of the family were Tories, and suffered, in consequence, many losses and privations. All traces have been lost of the brother who settled in New Jersey, even to his name; probably this branch of the family has become extinct.

It is with the third brother, who settled in Pennsylvania,James Agnew, - that interest centres for the readers of this biography, for he was the great-grandfather of David Hayes Agnew. 
Settlements were made on Octorara Creek by the Scotch and Irish colonists about $171 \%$, and later throughout other portions of lincaster and Bucks Counties. About 1737, many of the Annew fitmily settled in the northwestern part of Tork (now Arlams) County, on 'Tom's and Marsh Crecks.

In the quaint, old, deserted burying-ground at Gettysburg, which is now completely overshadowed by that greater gravevard which marks the high-water mark of rebellion, lie a number of the earlier members of the Agnew family in this country. In this quaint old burying-ground on Black's turnpike, a mile and a half out of the rillage of Gettysburg, there are a number of grave-stones sacred to the memory of many of the Annew family. On one stone there is a rude carving of weights and measures, with the further inscription: "The Weights and Measures of Scotland." On another is the coat of arms of the Annews of Lochnaw.

1)r. Agnew took a pathetic interest in this deserted little spot, where so many of his family were laid to rest, and always, when he went to Ciettraburg. spent a portion of his time in the place, taking tracings of the rarious stones.

There are few families which exhibit, to such a marked degree, the same physical, moral, and mental characteristics. 'The members of the Agnew family have always been remarkible for their great height and splendid physical development. It is, undoubtedly, this great physical activity which has held them so together as a family through all the tumultuous and disturbing periods which succeeded the Norman Conquest in Fingland, and the same rude separating influences of the similar period of European invasion in America. No finer cxample exists of this trait of height and physique than in the fither and uncles of Dr. Agnew. Mis father, Dr. Robert Agnew, was the shortest of seven brothers, his height being six feet two inches. His tallest brother towered to the height of six feet seven inches. Another marked characteristic of the Agnew family was their extraordinary mental actirity, and 
their keen perception of the duties and requirements of their life-work. No family exists which shows, on a whole, a higher degree of these traits. In whatever branch of life-work they are found, they stand pre-eminent.

Undoubtedly, however, the most remarkable characteristic possessed by the family has been their great prominence in religious matters. They have been always active in all the observances of religion, both in church-work and in their daily life. The three original heads of the Agnew family in this country were all elders of the same church,-the Seceder, or Associate Presbyterian.

It is a curious problem for students of genealogy to note that the Agneaux who remained in Normandy, wholly separated from their brethren, became Protestants, as well as did the Scoteh Agnews. In fact, their Protestantism was more remarkable because of the adverse tendency of their surroundings.

Probably there exists no fuller or more comprehensive biographical record of any American family than that of the Agnew lineage. Imbued with a clamnish love of race, they have kept religionsly the history of their family. The various American branches, like the English, have been prolific of offspring; and yet, in the various phases and separations to which American families are subjected, which render any lineage of an American family so difficult to complete, no traces of the different ramifications have been lost. In regard to the American Agnew family, much of the credit for preserving these records and placing them together is due to the late Smith Agnew, of Pittsburgh, who devoted forty years of his life in traveling and collecting, in a permanent shape, the biographical outline of his family. These records he arranged in chronological order; in this shape they are invaluable to the American Agnew family.

James Agnew, the founder of this branch of the family, was born in Oetober, 1711. He was married twice; by his first wife he had two children. It is, however, with his second 
wife, Rebecca Scott, that we are interested, for from her Dr. Annew was descended. They were married in the year 1737, and, following out the traditions of the Agnew family, had nine children, - Samuel, Martha, James, David, Margaret, Rebecca, Sarıh, Abraham, and Anne. Of these children, many became rery well known in the early settlement of Pennsylvania. It is, however, the fourth child by his second wife that is of importance to this biography.

The name of this son was Darid Agnew, and he was born July 17. 1743. On attaining his maturity he was married, in Franklin County, Pennsylvania, April 2, 1772, to Mary Erwin. This comple are of historic interest, for they were the grandparents of 1)r. Agnew. 'They had twelve children, which was a moderate-sized family for an Agnew. The record of the births of these children is so interesting that we venture to copy this portion of the family record in its entirety. It will be noticed that a child was born nearly every two years:-

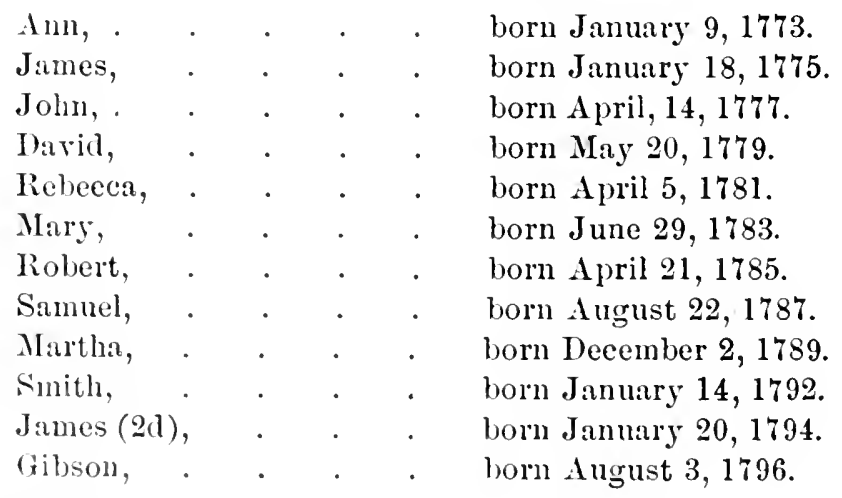

Darid Agnew did not live to be an old man, dying soon after the birth of his last child, on the 17th of January, 1797, at the age of 5:3 years. After four years of widowhood, Mary Agnew, his relict, married the Rev. Alexander Dobbin, who was then a widower with seren children. This made a combined family of cighteen children. They lived happily together until her death, in $18: 4$. 
Robert Agnew, the seventh child of Darid and Mary Agnew, who was born April 21, 1785, became later the father of Darid Hayes Agnew, the subject of this biography. He was married, August 1, 1815, at 30 years of age, by Rev. Ebenezer Dickey, to Agnes Henderson, who was, at that time, a handsome widow with two children. Their only child was born three years later, November, 24, 1818, and named David Hayes Agnew.

Mrs. Agnew's maiden name was Agnes Noble. Her first husband was the Rev. Ebenezer Henderson, a Presbyterian minister, by whom she had two children.-James $\mathrm{N}$, and Mary A. Henderson. The Rev. Ebenezer Henderson was one of the pioneer Presbyterian preachers of America. His father, the Rev. Matthew Ifenderson, had been sent to this country by the Associate Synod of Edinburgh, being the fourth minister of that church, in order of time, entering upon this work in America. The Rev. Ebenezer Henderson's first charge was in Pittsburgh, which was, at that time, in a very wild and uncivilized condition; it being necessary to make the trip over the Allegheny Mountains on horseback. Mrs. Henderson, on one of these trips, carried her infant son upon a pillow on the saddle before her.

Mrs. Agnew frequently described the church services of those early times, which, in the absence of a church building, were often held in the open air, even in mid-winter with the ground covered with snow. A call was given to Mr. Henderson to succeed Mr. Marshall as the pastor of the First Associate, now the First United Presbyterian Church in Philadelphia. The Presbytery placed it in his hands with the stipulation that before entering on his pastoral work he should visit the scattered flocks of their adherents in the South. This duty he fulfilled, but on his return he was attacked by a violent fever brought on by exposure to the elements, swimming rivers, etc. $\mathrm{He}$ died at Staunton, Va., before he reached home. Intelligence did not then fly with the speed of lightning, and, while 
the congregation eagerly awaited the arrival of their pastor-elect, they received the news of his death.

Robert Agnew, the father of the subject of this biography, was born in Adams County, Pennsylvania. He received his general education at Dickinson College, and studied medicine under that great teacher who elevated obstetries into the dignity of a distinct branch of medical study,-Dr. Thomas Chalkey James, of Philadelphia. After the completion of his course in medicine, he became a surgeon in the U. S. Nary. On his first trip, which was to Canton, China, the vessel in which he sailed, left the port of Philadelphia, intending to round Cape Hom and cross the Pacific Ocean. This plan, fortunately for posterity, was frustrated by an accident. The ressel was wrecked, off the coast of North Carolina, in a storm, and Dr. Agnew, narrowly escaping death by drowning, reached shore in an exhausted condition. The ressel being totally destroyed, there was nothing left to do but to return to Philadelphia. Upon his return Dr. Agnew decided to give up his original intention, of becoming a naval surgeon, and remain on shore. Thus, providentially prevented from leaving his native land, he settled in Lancaster Comnty, Penusylvania, at Nobleville, a town which is now called Christiana. Here he became extensively known and respected, both as a physician and a man. He acquired a large practice after a comparatively short residence in this section of the country, and many of the older generation still remember him as haring been their family physician. Scores of children in Lancaster and Chester Counties were named in his honor.

so influential did his opinions become that he was elected, agrainst his wishes, to represent Iancaster County in the State Legislature for two successive terms. Dr. Agnew met and married his wife while living at Nobleville, and his only son was born in the quaint Noble homestead, near Nobleville. After twenty-five years of active practice as a country physician, Dr. Robert Agnew determined to be relieved of his laborious duties, on account of ill-health; but he was so popular and his services 
were so in demand that he found the only way to accomplish this was to leave his old home. Consequently, he removed to Battimore County, Maryland, in 18t0, where he purchased a handsome country-seat, "Blenheim." Even this change of residence did not prevent his being sought out by his former patients, or by those who had heard of his reputation as a practising physician. In consequence, with the compliance which was so noticeable in his son, he visited the sick and gave counsel for many years afterward, until shortly before his death; so that it can be truly said that he was engaged in the performance of the trying duties of a country physician for nearly half a century.

The description which exists of Dr. Robert Agnew's personal appearance shows whence his son derived much of his physical and mental composition. He was a very handsome man; his countenance expressed the mildness and modesty of his character, while his height gave him great dignity and impressiveness. Yet, while modest, retiring, and gentle in his disposition, he possessed great determination of character; and when he felt he was in the right, he was firm and inflexible. He was a close observer of men and things, and was a keen stndent on many questions. He read and studied much, not only in the department of medicine, but also in the domain of general science and literature. He was very methodical in all that he did, and showed great thoroughmess and accuracy. In fact, it is stated, by all who knew him, that he showed, in his characteristics, the qualities which so distinguished at a later period his more celebrated son.

Dr. Robert Agnew was also prominent in the Presbyterian Church, carrying out the traditions of his family. In 1828 he was ordained a ruling elder of the congregation of the Presbyterian Church at Octorara, and until his removal to Maryland his relation with Session was șmpathetic and cordial. He died of pneumonia, at his residence, "Blenheim," Baltimore County, Maryland, October 10, 1858, at the age of 73 years.

Mrs. Agnes Agnew, the mother of Dr. I). Hayes Agnew, 
was born in Lancaster County, Pennsylvania, January 30, 1781, this making her four years older than her second husband. On her side of the house the associations with the Presbyterian Church had been as intimate and cordial as on the Agnew side. Her father, James Noble, had been an elder in the Associate Church at Octorara, while her grandfather, Willian Noble, had been one of the founders of this famous old church, which, with the neighboring congresation of ()xford, formed the original seat of Assuciate Presbyterianism in America. As has been said, Mrs. Agnew was wife tirst of a minister and then of a physician. She was well fitted to occupy these two prominent positions in American society, for she was a woman of the most extraordinary force of character. possessing a powerful mind and an indomitable energy. From her descent and her associations she was deeply religious in natire, which tendency increased as she grew older. As a young woman, possessing a magnificent physique and tireless energy, she had lived a life of greatest hardship as the wite of a frontier minister. The hardships of such a life, which would always fall harder on the wife and mother of the family, did not affect her health and spirits in the least, although her husband, the Rev. Ebenezer Henderson, succumbed to them early in his career.

As the wife of the active country practitioner, Mrs. Agnew brought into use the energies and faculties which, by long training, were suited pre-eminently for such work. Always serene, contented, and cheerful, perfectly guileless, and ingenuous in character, she reached her old age with a mind unusually clear and full of the knowledge of IDivine truth. Undoubtedly, to her traning and influence her distinguished son owed many of his chatacteristic traits. She walked daily with God, and ripened for $r$ lory until she reached her ninety-first year, dying, February 25, 1 571 , of a paralytic stroke. Although she was 37 years of are when her famous son was born, she lived to see him reach a foremost position in his professional work.

To the last she was employed in the reading of her favorite 
books. Her study of the Bible occupied the principal portion of her time, but she was also deroted to the standard religious treatises of her youth: "Boston's Fourfold State," "Owen on Forgiveness and on the Spirit," "Edwards' History of Redemption," "Baxter's Saints' Rest," and "Henry's Commentaries." To her son, when he was summoned to her dying bed, she said, "You have come to see the broken fiame of your old mother, but in my feebleness I have still great cause for thankfulness,-God has kept my mind untouched." And, as if to assure him of the fact, she commenced to repeat her farorite chapter, beginning "Let not your heart be troubled."

Her eldest son, James N. Henderson, born in 1803, was, consequently, fifteen years older than his half-brother. He was not married until late in life, dying in 1887, at the family seat near Baltimore, aged $8+$ years. Mary A. Henderson, her only daughter, was born in 1805. She married Davies Wallace and raised a large family. She is still living, her home being in Lancaster County. Between this sister and Dr. Agnew there always existed the greatest love and sympathy.

A number of Dr. Agnew's relatives became so prominent in the history of Pennsylvania that they demand brief biographies in any history of the Agnew family. Darid Agnew, Dr. Agnew's grandfather, was quite as ready to resist oppression as his ancestors had been, and, when hostilities commenced in the colonies against the British rule, he espoused the colonial cause. Dr. Agnew's great-uncle, James Agnew, was a colonel in the Continental army, and was wounded in one of the battles in New Jersey. In that struggle many members of the family bore honorable and patriotic parts, although they knew that in the English army were many relatives and friends. Among these was General James Agnew, who fell at the Battle of Germantown, a commanding officer in the English army. The following account of his death at the Battle of Germantown, Philadelphia, while a member of the staff of General Howe, is found in Watson's "Anmals of Pliladelphia" :- 
" It the time of the battle, General Howe came as far as the marliet-square and staid there, giving his commands. General Agnew rode on at the head of his men, and when he got as far as the wall of the Memonite Church he was shot by Hans P. Boyer, who lay in ambush and took deliberate aim at the star on his breast. He fell from his horse, and was carried to Mr. Wistar's house, where he died in the front parlor. General Annew was a very ciril and gentlemanly man. The man who killed him was not an enlisted soldier. . . . General Agnew and C'olonel Bird, of the British army, are both buried in the lower burying-ground, side by side. General Agnew showed great lindness to those with whom he came in contact."

The house in which General Agnew died was one of the celebrated places of the city fifty years ago. It was photographed on account of this incident, and many of the older collections of the famous houses of Philadelphia contain. a copy of this quaint, old, typical Germantown home, which still stands. on Germantown Road.

1)r. Agnew's uncle, Samuel Agnew, was killed. during the War of 1812, at the Battle of Chippewa. A cousin, Dr. Samuel Agnew, was a surgeon in the army during that period.

Among the best-known members of the family was Colonel James Agnew, a cousin of Dr. Agnew, who was born in Adams County, Pa., July 21, 1769. His parents were of the Reformed Presbyterian (Covenanter) branch of the Clumeh; but at the time of the union of that body with the Associate (Siccelers) ('hurch, forming the Associate Reform Church of North America, they joined in the Union. The following incident, related of his mother, Mary Ramsey, shows the unsettled condition of the country: She was attending school, living for the purpose at the house of a brother, Colonel Ramsey, in Franklin County. One day she felt a special aversion to groing to school, which became so strong that she yielded to it and remained at lome. That day a band of hostile Indians came upon the school-house, murdering and scalping the teacher 
and all the small children, and carrying the larger boys and girls into captivity. Had she gone to school that day, she would either have been killed or taken captive.

At an early age young James Agnew went to live with his maternal uncle, Colonel Ramsey, who owned an estate on West Conococheague, near Mercersburg. At the time of his advent, emigration to Western Pennsylvania had been inaugurated, and a considerable trade was carried on between the settlers west of the Alleghenies and the older settlements of Cumberland Valley. This trade was carried on by means of pack-horses, and the route corresponded nearly with the present turnpike. By the assistance of his uncle, young Agnew established a tradingpost in the "Great Cove"; the nearest store to the east was kept by a Mr. Buchanan, whose son, James Buchanan, afterward became President of the United States. At this station, where McConnelsburg now stands, James Agnew built up a very prosperous business, so that he subsequently became one of the wealthiest men in Pennsylvania. He was for many years a ruling elder in the church, and his home was lnown as "the ministers' hotel." This arose from the cordial hospitality with which clergymen of all denominations were receired and entertained; this hospitality being practised for weeks and months at a time. He was killed by falling down stairs, in 1855 , in the eighty-seventh year of his age.

An incident which illustrates his character for brave and firm adherence to principle and law is as follows: In those days, before canals and railroads, the Conestogal wagon was the only means of conveying freight from Philadelphia to Pittsburgh. These sometimes formed a long caravin on the road that passed through McComnelsburg.

Very few teamsters gave themselves and their horses the benefit of the Sabbath's rest; the noise of the wagons and horses, and the boisterous roices and oaths of the drivers, became a nuisance to the people along the route. It was known that Colonel Agnew was one of the persons opposed to 
this, and it aroused opposition among a portion of the community ; they conspired to annoy him by nominating him for the office of constable. He was elected, and accepted at once his duties. He now determined to enforce the law, which he did with the greatest zeal and firmmess, as it was illegal for the teamsters to do this transportation on Sunday. One Monday morning, attempting to arrest a large and powerful teamster, who had violated the law the day before, he was resisted. Colonel Agnew was a large, finely-built man, over six feet in height, and rery strong; the teamster was also stalwart and riolent, and withstood so fiercely that the colonel was not equal to the task. Dr. George Junkin, who was his guest at the time, rushed to the help of the officer; by his aid the giant. wagoner was overpowered and carried before the magistrate.

Colonel Agnew was an early and consistent firiend of the temperance reformation. He determined to banish all liquors from his own store; his partner, to whom one-third of the profits was given, objected, as it was a very profitable portion of the business. Colonel Agnew, however, directed his partner to make a calculation of the usual amount of income from this source. 'This was done, and one-third of the amount was ordered to be added to the partner's receipts, and all wines and liquors were banished from the place.

Dr. Samuel Agnew, brother of James, was a physician, being born, August 10,1777, near Gettysburg. After his graduation at 1)ickinson Collegre, in 1798, he studied medicine. During the War of 1812 he served as Surgeon in the Army, but settled afterward in Harrisburg, Pennsylvania. He became so well known that the late Professor Samuel Jackson, of the Lniversity of Pennsylvania, remarked, on one occasion, that "if he had an only son dangerously sick, there was no physician between Philadelphia and New Orleans whose services he would rather have than those of Dr. Samuel Agnew." His eldest son was the Rer. John Holmes Agnew; his second son, Judge James C. Agnew. He was a ruling elder in the first Presby- 
terian Church in Harrisburg for fifteen years, and a corporate member of the American Board of Commissioners for Foreign Missions for a long time.

Rev. John Holmes Agnew, son of Dr. Samnel Agnew, and cousin of Dr. D. Hayes Agnew, was born in Gettysburg in 1804. He became a minister, but soon relinquished pastoral work and was elected Professor of Languages in Washington College in 1831. He subsequently became professor in a similar position in Newark College, Delaware, from which he withclrew because the funds for the institution were raised by lottery. Ite was also editor of The Kniclerboclier, The Eclectic Muguzine, and the Biblicul Repertory, a quarterly in the interest of the then new-school branch of the Presbyterian Church. He was also author of a valuable work on the Sabbath, and he assisted in the translation of Winer's "Grammar of the New Testament." He died in 1865.

Samuel Agnew was born, November 18, 1814, in McConnelsburg, Fulton County, Pennsylvania. IIe was the youngest of eight children of C'clonel James Agnew. Ile was a student for some time at Washington College; subsequently he remored to Philadelphia, where he entered into business. After remaining several years in business, he retired from mercantile pursuits and engaged in the book-publishing business at sixth and Chestmut, bringing out the series of Goodrich's (Peter Parley's) School Histories. He withdrew from this business about 185j and devoted his leisure time to the formation of a library for the Presbyterian Historical Society, which he originated in 185:2, and of which he was, until the time of his death, Troasurer and Librarian. In addition, Mr. Agnew made special collections of books on this subject; for example. his collection of works on the subject of Baptism numbered 7000 rolumes. IJe was married, December 10, 1840, to Susan, daughter of Robert and Susan Coxe Erwin, and left one child, 1)r. krwin Agnew. IE died in Philadelphia, March 6, 1880.

His son, 1)r. Erwin Agnew. was born Fobruary 22, 1842, graduating in medicine, at the University of Pennsylrania, in 
1864. He gave up the practice of medicine carly in his career, and deroted himself to the ane of his cstate. Although a man of most rigorous constitution and methodical habits, and coming of a long-lived race. yet his life of great usefulness was cut short by his sudden death. september 4.1891.

The IIon. Ianiel Innew, ex-Chicf Justice of the Supreme Court of Ponnertrania, is also a member of the Agnew family, his ancestors coming from the County of Antrim, in the north of Ireland, in 1764 . Althongh no definite relationship can be traced between Dr. Agnew and him, yet the resemblance between lis father and uncles and Dr. Agnew's family was so striking that there would be no hesitation on the part of a stranger to proclaim then near relatives. He was born, January 5. 1809. in 'Trenton. New Jersey, and was brought west, in 1813, to Bearer. Pennsylvania, where he resides at present. Judge Agnew has always borne a prominent part in the history of Pemirtrania, and his clear exponndings of constitutional law and legal points have been receired with the greatest confidence and respect

I is father. James Agnew, A.M., M.D., gradnated at the University of Pennsylrania, in the Medical Department, in 1800 . Wis graduation thesis was on the subject of "Perspiration," and. als was the custom at that period, it was printed in pamplilet form, bound with others in a handsome volume, and prescuted to the different libraries of the time.

Inother member of the firmily, a cousin of Dr. Agnew, was 1)r. Comelius R. Agnew, of New York, who was born in that rity in 1 1830. and craduated at Columbia College in 1848, and afterward at the College of Physicians and Surgeons. He became a distinguished ocmulist, and died in the midst of his usofuluess, April 1s. 18ss.

lier. Benjamin I. Annew, son of Smith Agnew, and a consin of I)r. Ignew, born October 2. 1833, is a prominent minister in the Presbyterian Church, having at present a charge in Philatelphia. 
The history of the Agnew family is given in its barest outlines, in order to show from whence the family sprung. Dr. Agnew had an honest appreciation of fimily; he did not value a man more or less on account of his ancestry;-not for a single moment,- -but he was fond, from his earliest childhood, of hearing the chronicles of olden times, in which his family bore prominent parts, and of studying and comparing the lives of its different members. His mind was stored with the tales and aneclotes of years ago, and his love for his family was one of his most marked characteristics.

An honest regard for an honorable ancestry is allowable in the most democratic of countries. 


\section{CHAPTER II.}

\section{The Eirly life of Dr. Agnet.}

DR. AgNew receired his name of David in honor of his grandfither, David Agnew. The name of Darid has always been a farorite one in the Agnew family, and his parents, in giving him this appellation, simply followed out one of the customs of the family in haring a Darid among their children. He received the name of Hares for his uncle by marriage,Robert Ilayes, of Gettrsburg; this gentleman had married Rebecal Agnew, tifth child of David and Mary Agnew.

1)r. Annew was a "born doctor"; he never remembered a time when he did not desire to be a phrsician. IIs father's profension possessed for him, from his earliest clildhood, the kecnest and most irresistible fascination. From the time that lie was first able to play, he would ride a cane for a horse, and, clad in one of his father's rests, which reached nearly to his hecls. he would stuff his pockets with bottles and powders, and pretend to visit his patients. At these times, if any one called at the house requiring his father's services, he would tell them thist he had sent the young doctor out to see a patient, but that the old doctor-meaning himself-was at home.

'The stories which are told of' the early life of Dr. Agnew show that he posseswed a keen sense of humor and a remarkabe intelligenee, even as a very little child. When scarcely able to walk and talk he would take his Grandmother Noble by the hand ami wilk through the garden with her. When he grew wealy he would saly. "Now let us sit down and talk over old times." lle lored to hear her tell of Revolutionary days,the trials, anecdotes, and incidents of that great struggle for independence. He knew no enjorment equal to this, and his memory was early stored with many of the daring adrentures and thrilling stories of Revolutionary history. 
He was never very fond of going to school, possibly because he lived in what might be called the "Birchen Age" of American education. This was the time when a teacher was regarded as incompetent unless he made liberal use of the oldfashioned birch-rod. Unfortunately, young Agnew had a very cross teacher, who was most proficient in the use of this very necessary instrument of education, and he did not escape an occasional punishment at the hands of this pedagogue. At one time, after being corrected in this mamer, young David felt very sick. His half-brother, James Henderson, who was considerably older than himself, happened to be near the school, when he heard a sad, small voice cry, "Jimmy, I've got the ague." The little boy had slipped out of school, and, seeing his brother in the distance, had followed him. As soon as "Davy"-as he was then called-reached his mother, the ague quickly disappeared, and Darid was himself again. This little incident was repeated a number of times, until the conviction was forced upon the family that it was a childish expedient to get away from his terrible teacher.

When about four years of age his mother took him to a camp-meeting, which was considered, in those days, a necessary adjunct to religious training. Young David possessed a very vivid imagination, and, unfortunately, one of the preachers happened to be telling the congregation about the Devil-a filvorite subject at that time-just after the arrival of his young aliditor. Becoming very warm in his efforts, the minister pointed his finger and cried out, dramatically: "There he is! Don't you see him?" Young David at this moment chanced to espy a lizard, and called out in retum, at the top of his small voice, "Yes, I see him, and I'll catch him, too." He caught the lizard, and held it up in trinmplh. It is neerless to say that his mother took him into custody as quickly as possible, but the effect upon the congregation is still remembered by those now living who were present.

When he was three years of age he was being prepared for 
bed one night, when suddenly he disappeared and could not be found. After a time, his sister, Mary Henderson, who was thirtern gears older than he, was entertaining a gentleman in the parlor, when she chanced to hear a small voice. This small roice exclaimed " Here nuc is." and out stepped young David, proudly, from under the table in the corner, clad only in Nature's covering. to the great confision of the young people present.

'There are some children who, from their earliest childhood, secm to realize fully the duties and responsibilities of life. Such a child was young David Agnew; he gave his attention from the ontect to his religions duties, and his mother stated subsequently that she conkl never remember the time when she did not feel that her son was a Christian.

In those days Sibbatl-schools were few, and it was the universal custom for the minister to catechise children publicly before the church service. 'This was an ordeal that helped to make mulaply the existence of the younger members of the congrenation. In these trials, however, young David always knew his lesson perfectly, althongh frequently his study of his Jible and catechism would be put off until the very last thing Saturlay night; but his memory was, from the earliest period, most retentive, and it was never any trouble for him to learn quickly and thoronghly.

Iis determination and lindness of thought were exhibited from his arliest childhood. At one time he was sick,-so sick that his family thought lie conld not live; and, in consequence, his mother was so much distressed by the thought that she left the sirk-room for a moment. It once he missed his mother, and said that they should call her back and tell her not to feel worrind ahout him. for he did not intend to die.

I pretty story is told of his first meeting with his future wife. While he was still a small boy, a gentleman stopped to see his finther on business, bringing with him a pretty, darkhaired little girl. The boy fell in love with her at once, and made the childich remark at the time, at which every one 
laughed, that he had made up his mind that he would marry her when he grew up. Although he did not meet the lady who was to be his wife for many years afterward, to know her well, strangely enough, the little ideal of his boyhood days was the one love of his life-the woman to whom he owed so much of his success - the woman who became to him, in after years, a real helpmeet.

Young Agnew was growing up in the most farorable surroundings for his future career. He was born in a doctor's home; he faced that life from infuncy. It was his childish sport to play the doctor, and he grew naturally into the doctor. His father and mother were thoughtful and honorable folk, deroted members of the old Presbyterian Church, lovers of their Bibles, students of Confession and Catechism, who gave many proofs of the faith of their ancestors and the strong, uplifting convictions of their own derout souls. Their boy was well trained, and his life-record is their monument.

Through these carly years he was perfecting the elements of his vigorous constitution, which stood him in later years in such good stead. The boy's life in the comtry then was even more out-door and wild than it is now, for game was then more plentiful in the woods and the comntry itself less under the control of cirilization. In all the boyish sports and games young Agnew early took the lead by his rigor and intelligence. II habits and customs were being instilled into him by his parents and companions too firmly to be changed to the day of his death by the enervating influences of city life. Fortunate in his parents, he was no less fortunate in the location of his early home.

After his experience at the country school, yomg Darid was sent to begin his classical education at the Moscow Academy, which was a flourishing Chester C'omnty institution of that period, in charge of the Rev. Francis Latta.

The incidents by which this academy received its curious name are interesting. At the close of the War of 1812 with 
Girat Britain, there developed in l'ennsylvania a mania for laying ont towns. Among others engaged in this project was the owner of a tavern called " The General Wayne," on the Philadelphia and Lancaster 'Turnpike, who sold his property, with fifty acres, for the exorbitant sum of $\$ 16,000$ to speculators, who laid out thereon a town, to which they gave the name of Moscow, from the city of Moscow in Russia, which had just been consumed by fire started by Russian torches to prevent its occupation by Napoleon Bonaparte. These speculators disposed of the property by lottery, the public-house being the highest prize. The streets were called by Russian names, and the lots were disposed of in this way at high prices.

The town flomrished only on palper, and the project failed. "Cossack Street" became again the common Laneaster Pike, and the others, with their Russian names, returned to the bosom of the farm from which they had sprung. It was on this property that, in 1526 , the "Noscow Acartemy" was built by Mr. Latta.

Here he received the foundations of a good classical education, and from here he was sent to Jefferson College at Camonsburah. Pa. This institution was at that time the stronghold of Presbrterianism in the western part of the State, and at such, naturally, attracted the attention of Dr. Agnew's pirents, when it became necessary to complete the education of their son. 'This college was an outgrowth of the Camonsburgh Academy of the carly part of the present century. It had been nimed for Thomas Jeflerson, in the hope that it would receive aid from him similar to that given by Washington to the college maned in his honor. Dr. Agnew was a student here in the winter of 1833-34, during the régime of Rer. Matthew Brown, who had been elected Principal in 1822, holding the position for twenty-three years. A further circumstance which probably influenced his family in the selection of this institution for the education of their son was the fact that Rer. James Ramsey, a connection of the family, had been a trustee of the college from 1805 to $18: 24$. 
Dr. Agnew did not stay to gradnate at this institution, as he had intended, but left to enter Newark Collegre, which hald just then been established at Newark, Delaware, by the Legislature of that State. He was attracted to this institution because his cousin, Rev. John Holmes Agnew, had been olected Professor of Languages there. Newark College had been established by the Legislature of Delaware to afford higher educational ficilities for the residents of that State; on May 8, 1834, it was opened officially; the inauguration addresses being delivered by l'rofessor's Nathan Mumroe and John Holmes Agnew. 'The college opened with sixty-three students on the roll, but all were so young that only one was entered in the college course. In 1843 the name of this institution was changed to Delaware College. It was closed from 1859 to 1870 , on account of difficulties in its management, but was re-opened and is now in a flomishing condition.

Dr. Agnew was one of the earliest students at Newark College, entering in the session of $183 t-35$. II leaves a record of his experience here, then a boy of 16, as follows: "We were a lively set of boys, and guilty of many foolish pranks, but, on the whole, not worse than the young men in similar institutions at the present time. 'The refectory was infamous,-poor food, and badly served."

While he was at Newark College, I)r. Annew was active in college life; with eleven colloagnes he founded the Atheneum Literary Society, and was one of its most camest supporters. Professor Holmes Agnew left Newark Collexe because it was supported in part by the proceeds of a lottery,-a means of sustenance of which he could not approve; in conseruence, there was no further inducement for his student-consin to remain. Therefore, Dr. Agnew did not stay to gracuate in this institution.

He had been looking forward eagerly for years to the time when his father would feel that he wats old enough to study medicine. He now felt that he had reached an age when he could enter upon the study of that profession, the performance 
of whose duties had been the dream of his boyhood. Therefore, after sturlying for a time at home, muler his fither's directions, he entered the Medical l)epartment of the University of Pemsylrania in 1s:36. being one of the youngest members of the class.

His selection of the Lnirersity of Pennsylvania as his school for study was a matural one. It that time this oldest American modical school stood asily at the head of medical instruction in America. Philadelphia was then the undisputed centre of medical instruction. and students were attracted, as they are to-diy. firom all orer the Lnion, and, in many instances, from far beroud the seas.

Iis adrent at the University of Pemsylvania chanced to be at a very fortumate period, for between the rears 1834 and 1840 the Medical Jepartment rose with a bound, as it were, fiom a state of stagnation and torpor to one of rivid and productive artivity, in which the student who felt ambition stirring within lim was amply furnished with incentives to vigorous effort. with a better provision for future usefulness. With the reorganization of the Medical 1)epartment, in 1835, the chair of the Practice of Medicine had been separated from that of the Institutes of Modicine, and I)r. Sammel Jackson was raised to this chair; while 1)r. (hapman retained strictly the teaching of Practice. 1)r. George 13. Wood was elected to the racant chair of Materia Medica and Pharmacy. At the same time, ill health obliging the Professor of Obstetrics, I)r. Dewees, to dreign the chair he had so brilliantly illustrated, it was filled hy I)r. Ingh 1. Ilodge, whose thorough. systematic, and impresive lenture inspired and guided his pupils for twenty-eight yatrs.

'These clanges were most fortunate; they supplied fresh stimulus to the tearching force and strengthened the weak spots in the curriculum.

In consequence of these alterations, the Faculty at this time consisted of the following professors :- 
Faculty of Medicine at the Cniversity of Pennsyleania, 1838.

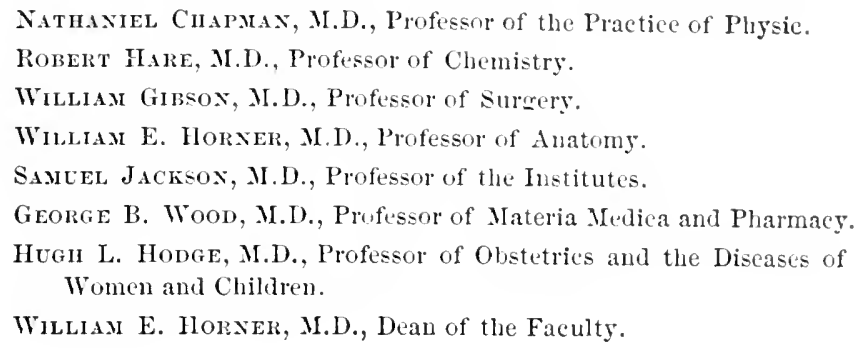

From 1835 until the year 1847 no change took place in the Faculty, when Dr. Hare resigned the Professorship of Chemistry, having been in possession of the chair twenty-seren years. As a lecturer, Dr. Hare had been remarkable for the skill of his experiments, which were miformly successful, impressing the minds of the students with their grandeur. His most remarkable discovery was the contrivance of the oxyhydrogen blow-pipe.

The elevation of Dr. Samuel Jackson to the Professorship of the Institutes of Medicine was a fortunate circumstance for the University. Beyond comparison the most brilliant and speculative lecturer in the Faculty of that period. he had the very rare power of swaying his audiences with his words and tones, using this power to take lofty riews of Medicine as a science and an art.

Dr. Nathanicl Chapman. as a lectmer. was self-possessed, deliberate, and emphatic. Whenerer warmed with his subject, his animation became oratorical. Often the theme of dry matter would be enlivened by some stroke of wit. happy pum, anecdote, or quotation. He was fresh with stores of facts and cases drawn from his own large experience and obseration. His bearing was dignified, his manners easy, and his gestures graceful. He had a thorough command over the attention of his class, with whom he always possessed unbounded popularity. His voice had a peculiar intonation. depending upon some defect in the conformation of the palate, which rendered the articulation of 
some worls an effort. When one became aceustomed, however, to the tone, his cnunciation was remarliable for its distinctness. ${ }^{1}$

Dr. William Gibson, as a teacher, was clear and emphatic; his roice wals distinct and melodious, his language was wellchosen, and his style of enunciation was attractive. His demonstrations of surgical anatomy were readily comprehended by the student; some of them conld not be surpassed in any respect. For the purposes of demonstration, Dr. Gibson had prepared himself, and procured by purchase, an ample collection of morbid structures of di-eased and fractured bones, models and casts, as well as pictures of large size, illustrative of diseases, or of the anatomical parts of the body inrolved in operations. To these were adled the approved mechanical appliances of that day. In teaching in this manner. he set the example that has been followed extensively by other surgeons ever since. As an operator he was undoubtedly dexterous.

Professor IHomer was not fluent or copious in language, nor had he any pretensions to clocution. His plan of teaching, to a certain extent, was novel. He composed a text-book which was a complete but concise treative on anatomy. It was written in strict reference to the course of study in the University of lemnsylunia. and was kept in as concise a style as possible, so that there shomld be no mmeresary loss of time in reading it. In the lecture-room he confined himself chicfly to the demonstrations of the text of his work by discussions, preparations, drawings and models. As to the ralue of this method there may be different opinions. but it made good anatomists. 'The students of the time frepuently declared that, plain, simple, and unadorned as were the lectures of $\mathrm{Dr}$. Horner, they learned

1 Dr. Chapman's realiness in martee may be illustrated by the following, in connection with the thection of a colleague. When Dr. Dorsey was ehosen to sueeced Dr. Wistar, he was muele gratifiel and elated at the prospect presented him of distinetion in the clair of Anatomy. Expresing limsilf enthusiastically with reference to his hope of acquiring reputation in that hranch. Dr. Clapman remarked that this had been already accomplished, as a muscle lial beeu named after him,-the latissimus dorsi. 
anatomy better from him than from ans other teacher. The Anatomical Muscum of the University, which had heen founded by Dr. Wistar, was greatly enlarged by the anatomical skill and untiring application of Dr. Horner.

Professor Trood's connection with the Lniversity forms one of its brightest glories. His election to the chalir of Materia Medica and Pharmacy had been productive of new interest in that branch in consequence of its being made more demonstrative.

This constituted the faculty which gave Dr. Annew his first medical instruction. He was always particularly fond of describing their traits and characteristies and the last specth he ever made, less than a month before his death, was deroted to this congenial theme. Dr. Agnew believed firmly what another student of the period has pleananty said: " It is my pleasure to imagine that they have not been excelled to the present day." This is the miversal, loval consensus of belief of all the students of the thirtics.

In order to see the extent of medical instruction of that day, with its advantages and limitations, a short résumé of the curriculum is necessary. 'The instruction in the medical schools at this period can be seen from the roster. which inchuded the fundamental branches of Medical Serence, Materia Medica and Pharmacy, Surgery, Practice of Medicine, Chemistry, Anatomy, Midwifery, and Institutes of Melicine. The very insignificant proportion of practical work formerly required of the student, and the preponderance of it at the present time. is the most noticeable change in medical instruction.

It is the spirit of the age to dericle the past and molerrate its advantages. 'There is no doubt but that there is too low an estimate placed on the extent and thoronghness of the medical teaching in the thirties. The mimutre points of medical science are forgotten by the plysician soon after his graduation, and only the practical knowledge which he needs remilns. This does not vary so much from the knowlerge of fifty years ago as would appear at first sight. 
Fifty years ago personal practical work was not required of the students; they derived nearly all they leamed from didactic lectures and "clinical conferences," so called. Only a few enjoyed the good fortune of receiving the personal bedside teaching of gentlemen who hat themselves been trained in the Paris horpitals. Through these younger men a wider knowledge of practical medicine and surgery became disseminated. A similar revolntion gradually took place in other cities, until, at the present day, the American graduate in medicine enters upon his professional life with a far completer panoply than was dreamed of by the reformers of half a century ago.

Still, the young men of the period were as studious as those of any other decade, and many of them were anxious to pursue a longer course than was demanded by the medical schools,attendance on two courses of lectures being all that was required. In the course of 1832-333 there were forty-seven students who were in attendance beyond the second course and twenty-six who held the degree of M.I). In 1833-34 there were fortythree of the former class and thirty-one of the latter class. In 1834-35 there were forty-seren on a longer course and twentysix doctors of medicine. After this time the catalogues did not report such students. It is known that many of those who were the most successful in their professional life attended three courses of lectures by their own choice.

It was not in didactic lectures only that improrement took place. From the commencement of medical teaching in Philadelphia bedside instruction had indeed been given at the Pennsylunia IIospital and at the Almshonse, but the credit of introducing medical patients before students in a lecture-room is ascribed to I)r. Benjamin II. Coates, ${ }^{1}$ physician to the Pennsylvania IIospital. in 1834, although these cliniqnes were but little less than informal didactic expositions of the diseases which the patients who were exhibited happened to present. It was not

\footnotetext{
1 Dr. Traill Green states that, wheu he was a student at the University, in 1834, cliniques at the Pennsylvania Inspital had been held for some time prior to this date.
} 
until the return of Drs. Gerhard and Pennock from Enrope, and the election of the former to the Pennsylvania IIospital ats attending physician, and of both gentlemen as attending physicians to the Philadelphia IIospital, that clinical medicine began to be taught in a systematic and fruitful manner.

With surgical cliniques the ease was somewhat different, since they conveyed, for the most part, instruction through the eye rather than through the unclerstanding, and, therefore, they have always attracted students by their spectacular qualities. During the period 1833 to 1840 , the two great hospitals were served by surgeons who were most eminent. At the Almshouse Hospital, the staff included Drs. William Gibson, Joseph Pancoast, William E. Horner, and Richard Inalan; at the Pennsylvania Hospital, Drs. Thomas T. Hewson, Joln Rhea Barton, Thomas Harris, Jacob Randolph, and George W. Norris.

It would be difficult to find, anywhere, a corps of surgeons more skillful, judicious, and successful than these. I Iorner was distinguished by his precision, Gibson by his clearness, l'ancoast by his vast experience, IIewson by his leaming, Inaris hy his prudence and knowledge of principles, Norris by lis wise conservatism and clinical investigations, and Barton by his ambidextrous skill, which he, as it were, bequeatled to one of his successors, - Agnew.

In these surgical operations, before the introduction of anesthesia, pain was not in all cases a depressing influence; for example, a boy was cut for stone, in the Penmsylvania IIospital, by lateral section; he promised that he would lie perlectly still if he were allowed to smoke a cigar during the operation. IJe bore the cutting with impassive tranquility.

The infusion of new life and vigor into the Medieal Faculty of the University of Pennsylvania was not followerl by an immediate and permanent increase in the size of the classes. Probably, in the present instance, the critics were too fir away and too ill-informed to learn of the improvement in the medical 
instruction here. The greater number of students were drawn from the Sonthern States; in 1833-34, out of a total number of four lundred and thirty-two, no less than two hundred and thirty came from States south aud west of Delaware. Yet, under the new régime begun in 1835, there was a steady increase in numbers until the Civil War, in 1861-62.

At about this date, $18: 36$, student life became more sedate, owing probably to the changes made in the Faculty, which tended to inspire the roung men with more serious ideas of the nature and purpose of their studies. 'This reformation occured almost simultaneously with a similar improvement, which took place in London, and which had been attributed in that instance to the genial but biting satire of the "Medical Student," in Punch.

I) rring the period 1830 to 1840 the medical department occupied what was then its new hall on Ninth Street above Chestunt. A larece proportion of the first-course students wore a decidedly bueolic aspect in manners and apparel. Very many of the classes of those days came from the Old Dominion; they brought with them, along with the wealth they lavishly dispensed, a fiectom, not to sily a license of bearing, which causol not only themselres, but the whole medical class they were supposed to typify, to be called "Ginuy Students" by the rulgar. They were specially looked at askance by the colored people, among whom a superstition prevailed that these gay young doctors "burked" negroes for the anatomical rooms.

In those days it was no uncommon occurrence for medical students to cngage in brawls in theatres and other public places, and to pass more or less of the night in the lock-up, unless liberated by the intervention of some professor. Indeed, going bail for disorderly students was regarded as an incident of the professorial functions. This custom was a natural result of the closel personal relations existing between the professors and students than have prevailed of later years. Almost every professor had a large class of private and office students, being so large in some instances as to become cumbrous. This fact 
led, on the one hand, to the establishment of the Medical Institute by Professor Chapman, in which he associated with himself several of his colleagues in the Faculty, together with one or two physicians who were not connected with the University, and, on the other hand, to the organization of several more or less private quiz classes. The first of these wils established by the late Dr. 'Thomas Dent Mütter, afterward P'rofessor of Surgery in the Jefferson Medical College, and by Dr. Paul Beck Goddard, so distinguished as an anatomist. The classes for private instruction were numerous.

A great feature of medical instruction at this time was the summer courses of lectures with private instruetion. In some instances, it was absolutely necessary for the students to talie some of these courses; for example, 1)r. Chapman's lectures on Practice at the University was not completed there, and his lectures in the Medical Institute filled out the course. IIs lectures on the discases of the nervous system he delivered during the summer months.

It was the practice of the students of this period to form quiz clubs, consisting of six or seven members, each member representing a professor. The cluty of the member was to listen diligently to the instruction of the lecturer or professor he represented and record notes. The chub met in the erening, and each member in turn quizzed the others. Every week or every two weeks, the members changed the subjects; for example, the man who had quizzed on chemistry exchanged with the man who had quizzed on materia mediea; so that each member of the club, in turn, quizzed on all the branches during the lecture course. These quiz chubs were possibly more effectnal than the modern method of emploring quiz masters. for cach member had a motive in taling notes on his sulject, in the hope that he might have the pleasure of " stumping" some of his colleagues at the club meetings. In this way a spirit of rivalry and competition was begotten, which spurred the students on to acquire fuller and more accurate medical linowledge. 
It was the custom of two of the professors to entertain the graduating clatss at their houses on Commencement ere, when the provision was less ancetic than is u-mal in these abstemious dars. The consequences were not always edifying from a decorous point of view; but the soberest among them may, perhaps, be pardoned for indulging a little in the greatest saturnalia of their lives. 'They had, but a short time before, passed through the ordeal of the ". Green Box." which was once a literal closet where the andidate for the degree was given over to his tormentors.

The " Green Box," or "Green Room," which is still eren employed as the term for an examination in medical subjects, arose from the practice of the professors at one period-1810 to $1821-e x a m i n i n g$ the candidates for the degree of medicine behind a sereen. This was a modification of the method which had been in operation before 1810 , when the professors examined first the student privately, and then publicly before the trustees to exlibit his fitness for the honor of the doctorate.

The number graluating with Dr. Agnew at the Medical Commencement. April 6. 18:39, was $14 t$; at the Commencement of the college department on July 12th 12 more were added to this list. making a total of 156 . In the "General Catalogue of the Nedical Itepartment of the University of Pemsylyania, with an Iin-torial slietch of the Medical Department, published by the birection of the Mcelical Ficulty of the University of Pem"lranial, thire elition. 184i)," the number of matriculates is given an 340 and the craduates as 15\%. This slight mistake in the number of erarduates is due to the duplication of the name of one of the students.

The (immenenement was held at Musical Fund Hall, on locust strect, between bighth and Ninth streets. It occurred during a period of a few years. in which the University term was prolonged to six montlis. boing afterward reduced again to a proriod of five months. Imong his class-mates and fellowgraduates were Joln Forsth Meigrs; Joseph K. Barnes, late 
Surgeon-General U. S. Army; Philip Lansdale, Surgeon U. S. Navy; James L. Tyson, now living at Penllyn, Montgomery County, Pennsylvania, formerly Professor of Materia Medica in the Philadelphia Medical College; Azariah B. Newcll, at one time Goremor of New Jersey; John D. Griscom, formerly a well-known practitioner in Philadelphia, who was sulsequently a neighbor of Dr. Agnew at Haverford; Henry E. Muhlenburg, of Reading; and Joseph Hopkinson, Jr., who was in charge of the Nower Hospital during the Civil War.

A search through the "National Directory of Physicians for the United States" discloses the fact that in 1890 there were at least twelve members of the class of 1838 still living. Subsequent inquiries, made during the summer of 1892 , revealed the fact that, out of this number, probably only four members remained, the other eight dying in the last two years. The living members (1892) as far as are known are Drs. James L. Tyson, Penllyn, Pennsylvania; S. G. Fauntleroy, Dragonsrille, Yirginia; James L. Motley, Sharp's Wharf, Virginia; and Philip Lansdale, retired Medical Director in the U. S. Nary, Philadelphia.

The following description of $\mathrm{Dr}$. Agnew at this period is given by a former class-mate :-

"I knew D. Hayes Agnew in 1838, when I graduated at the University of Pennsylvania, but my relations with him were not intimate. He was a quiet gentleman, as I remember him, but indefatigable in his close attendance in the lecture-room. It was the custom of some of the professors, in that day, to catechise the two first rows of students on the subjects of the preceding lectures,-particularly by Horner on Anatomy, Wood on Materia Medica, and Hodge on Obstetrics, as well as occasionally Gibson on Surgery, - so that the questions and answers could be heard throughout the rotundit. Being one of these, and familiar with most of the others who underwent this somewhat trying ordeal, I remember that Agnew's well-markicd presence was seldom absent at these times, especially if anatomy or surgery were the themes. More than half a century has 
elapsed since the time refered to; but I find that my memory, although occasionally a little treacherous, is more tenacious of distant events than of thoes of more recent origin.

"The subject of slavery in the South was at that period rife in the minds of all. and many collisions, engendered by discussions on the prolifie theme. gave rise to divers canings and fisticutfs among the malcontents; so much so that Professor Gibson one day made the remark that 'the very devil seemed to have broken ont among the students.' In none of these dissensions, however, did Mr. Aguew in any way participate, but quietly pursued his studies, undetered by the conflicting elements around him.

- Not far from the University, which was, at the time I refer to, on Ninth street, north of Chestnut, there was, in a back street, near by, a certain house whose rooms were appropriated for anatomical dissections by some specialists in that department, which I had desired to possess, with a view of pursning and perfecting $m y$ studies in that branch; but to $\mathrm{my}$ (hagrin, at the time, I learned they had already come into the po-mention of Mr. Agnew, and I have little doubt that here he laikl the first foundation of his great skill in surgical operations, which was destined to place his name high on the rolls of fame in surgery, unsurpassed as he was in this or any country in the worle."

As shown in this accomnt, there was a custom among the students at this period of engaging such rooms for anatomical work. They were not comnected in any way with the School of Anatomy, which was then in active operation, under the care of I)r. Joneph Pancoast. although on the same street.

Aenew's determination to study anatomy more fully even than was required by the curriculum throws an interesting light on his ambition. Ifis love for this laborious and too frequently necklected luanch of medicine was not acquired; it was instinctive. As he expressed it himself. in speaking of the dissectingroom of the School of Anatomy: .. 'Those dingy old rooms had 
more attractions for me than the frescoed and fretted walls of a palace, and those anatomical odors were sweeter fur than those of Araby the blest."

Dr. Agnew registered himself for graduation as Darid H. Agnew, the title of his graduating thesis being "Mrolical Science, and the Responsibility of Medical Character." Lp to this time, and until after his marriage, he signed himself in this manner, making the change to I). Hayes Agnew at the solicitation of his wife, who disliked greatly the name of David.

During the fire in the Medical Department at the University, May 30, 1888, the Stillé Library, a valualble collection of medical books, in the third story of the Medical Hall, was damaged by water to such an extent that, at the recent re-arrangement of the books in the University Library, those that had been rendered illegible were destroyed. Unfortunately. all the theses for the year 1838 were among this number to be destroyed; consequently, all trace is gone forever of Dr. Agnew's graduating essay. Curiously enough, the essays for the years prior to 1838 are in a good state of preserration, as are also those after the year 1839, the years missing being 1838 and 1839. Fate seems to have decreed that one of the few essalys which would be of interest at present should be lost.

It is to be doubted, however, whether the entire loss of these graduating theses would be a serious blow to medical literature. They were composed under unfortunate circumstances, at a time when the medical students were worn out and depressed by a hard winter's course; their composition was regarded as an irksome and unpleasant task; but little time could be given for original investigation, consequently they were copied largely from the text-books, and they were shirked as much as possible. In consequence, many of them are decidedly schoolboyish in composition and in the treatment of their subjects. On the other hand, the necessity for reading one humdred and fifty of these essays ammually was an equally mpleasant task for the Faculty. The removal of this requisite for graduation within 
the past fifteen years was a wise act on the part of the authorities of the Medical I) partment.

Although 1)r. Innew's graduating thesis has been destroyed. yet it is posible to see its drift from its title; he always held strict ideas upon the special responsibilities of a plysician, and. maloubtedly, in this first essiy, wrote on a subject which was an especial farorite with him during his whole life.

After graduating at the Lnirersity of Pennsylvania, in 1838, I)r. Agnew returned to Nobleville in order to assist his father in his very extensive practice. He remained with his father in this raparity for two years, until the latter's removal to Maryland. in 1sto. The elder Agnew was a terrible sufferer from asthma, and his removal was made not merely to get rid of the exactions of a laborious country practice, but also in the hope of finding a rlimate more suited to his constitution. After his removal to Maryland. he suffered but little from his asthmatic attaclis. The younger Agnew lived, at this time, in the old Noble homestead. where his parents had lived before him for many years.

His mother's fumily had long dwelt in this location. The village had been called for a long time Nobleville, in honor of the family. It was sonth of the Philadelphia and Columbia Railroad, subsequently the Pennsylrania Railroad, which had junt been built to comnect Philadelphia with the canals farther went. Its title was changed to Christiana, in 1847, in honor of Chritiana Noble, wife of William Noble, Dr. Agnew's uncle.

While living here he formed the acquaintance of the lady who was to play subsequently, an important part in his carrer: Margaret Creighton Irwin. daughter of Samuel Irwin, of Pleasint Garden lron-Works. Their parents had been friencls for a long time, I)r. Robert Agnew having been their family physician for many years. On his removal south, in 1S40. the younger 1)r. Annew was called in to attend some members of the Irwin family who had been injured in an accident. 'The relations between Dr. Agnew and the Irwin family 
continued to grow more intimate, until, finally, the strong attachment between Miss Irwin and himself culminated in their marriage at the old homestead, at Pleasant Garden, Chester County, Pennsylrania, the wedding ceremony being performed by Rer. Wm. Easton, on Norember 21, 1841, three clays before the doctor's twenty-third birthday.

Mrs. Agnew's fumily were so solicitous for the young couple to live at home with them that they spent the winter of $18+1-42$ at Pleasant Garden, Dr. Agnew continuing his practice at this point. In the spring, however, they determined to return to his original office, in the old homestead at Nobleville. They remained here until Dr. Agnew decided to give up practice, a year later.

Samuel Irwin, Mrs. Agnew's father, died March 17, 1842, leaving his large business to his children.

The selection of his future companion and helpmate was one of the most fortunate circumstances of his life. It is hard to say how much of Dr. Agnew's success was due to his wife, but certainly a large portion of it was the result of her energy, intelligence, and determination; for she supplied the tireless, everactive impetus which kept him from being satisficed with his first efforts. He learned at this time a young doctor's life of incessant and ill-paid toil in that finest of first fields for medical activity, -a diversified comntry practice,-where a man of medicine is saved for all time from cramping one-sidedness, and where, of necessity, he endures hardness and makes firm backbone. 'They were days of wearing toil, of sturdy effort, and strady struggle. He has told, in his own calm, crisp, chcery sentences, of those first years of professional life._- "hard riding, hard reading, hard working, and small fees." Here it was he gained first his own resistless eye of instantaneous insight from which nothing seemed to be hidden, that marrelous judgment for the subtle secrets of the human body, those nimble fingers apt for any delicate operation, and those murivaled hands of co-equal power. Dr. Agnew was, at that time, a fimous sportsman; he loved 
to talie his gun and go in search of game, which was then very plentiful in the woods of Lancaster and Chester Counties. In such expeditions he became a leader from his earliest youth, and his foume as a hunter still lingers as a legend in these regions. There were one or two incidents of this wild outdoor life thit he could never forget, especially as, in one of these oceurrences, he nearly lost his life. In Lancaster County, in those rears, fox-hunts were a great source of amusement and recreation. 1)r. Agnew took the foremost place in these hunts, riding a famous jumper ealled "Tom." This was not so much an individual as a gencric equine appellation, for the steed was of a breed called "Toms," found only in Baltimore County, Marvland. History says, no doubt with truth, that a British officer, during the Revolutionary war, left a magnificent stallion in Baltimore County, which was the sire of the "Tom" breed of horses, fomous for more than a century in Maryland. They are closely built, nuscular. great jumpers, with wonderful endurance, intelligence, and spirits. Most of them are of a bay color, with black manes and tails, and arched necks. All these peculiarities, in a remarkable degree, were possessed by Dr. Agnew's fox-hunter, -an animal that was long famous, even in Lancaster County, for its speed and abilities as a jumper.

It was a frosty morning in the fall when Dr. Agnew and several other gentlemen followed a pack of fox-hounds to the fields in a particularly beautiful portion of fair old "Lancaster" ; the dogs soon striking the trail of the fox, dashed off in full cry. After them rode the humters, with rapidly increasing speed, over con-ficlds and across ditches, jumping such fences as came in their way, filled with the delight of the ride in the crisp air and the excitement of the chase. The fox led toward a range of hills, and, while the others kept on directly after the hounds, Dr. Annew took a "short cut" across country, intending to head off reynard as he tmmed back on his tracks, as he was almost sure to do.

"Tom" bore his master gallantly across a decidedly rough 
country, leaping ditches as if the task were sport and sailing over low fences and hedges as birds sail over a line of trees. The cries of the hounds grew fainter in the distance as they liept straight on upon the trail of the fox, and the other hunters had long passed out of sight; but, knowing well "the lay of the land," Dr. Agnew pressed on until he saw an exceedingly high fence before him, and pulled on the bridle to check "Tom" until he could lower the rails for a passage. The horse's blood was up; he, too, felt all the excitement of the chase, and, taling the bit in his teeth, he rushed on. His rider, seeing how near the fence was, whipped the steed and let him go as he would. The horse, when a few feet from the fence, made a long jump, rising in the air like a lark from her nest; but his hoofs struck the top rail and down he fell on the opposite side, throwing his rider off with a stirrup entangled about one foot.

Dr. Agnew was thrown partially in front of the horse, and he knew that if the animal stirred he would be dragged. He knew, too, in a moment, that "Tom" might roll forwarlthe animal was on its knees-and crush him to death; but the blooded animal did not stir. Although the horse wals on his knees, with his hind legs half crushed under him, he lay like a block of stone, looking at his master. Slowly, painfully, the bruised physician disentangled the stirrup, and, rising to his feet, found that no bones were broken. Not until then did "Tom" rise. The phissician gratefully reflected, as he rode slowly homeward, pretty well shaken up, upon the intelligence displayed by the horse, which saved his master from injury, probably from death.

Some years later Dr. Agnew became fond of duck-shooting. For a number of years he went regularly to Chesapeake Bay to indulge in this fascinating sport. About cighteen miles below Havre-de-Grace there is an island fimons among duckshooters, where Dr. Agnew had many remarkable experiences, so far as exciting sport was concerned. On one oceasion the doctor's boatman told him, as the sun began to decline, that he 
would have a wonderful experience, if he did not mind standing in water up to his knees for aloout half an hour.

Twenty minutes later. just as the sum dipped beyond the western horizon, and it was " neither day nor night," Dr. Agnew and his boatman, standing in water ncar the edge of the bay, and concealed in the tussocks, held their guns in readiness. Pretty soon a clond appeared,- - a clond of black ducks coming to roost. As they prased overhead, the guns re-echoed and scores of the water-fowl fell dead. The sportsmen hardly had time to reload before another Hock came. Many more were bagred. Then the ducks were seen on all sides. They came in flocks of hundreds cach, to roost in the tussocks as the twilight deepened. and in the agoregate they numbered thousands. The hunters killed duckis by the score until it became dark, which was about twonty minutes after the arrival of the first bunch of water-fowl. There are not now many such duck-roosts in the workl.

Dr. Agnew was never a happier or more attractive companion than when off for a day with dog and gum. During his comection with the Scliool of Anatomy this formed his only recreation, and in after years he often spoke of these happy days with the graitest pleasure. At that time he was a superb shot and a strunger to fatigue. His steadiness of hand, quick, decisive judgment, and sharp eye were as useful to him at the successful sportsman as they were in the successful stllewertl.

Is I)r. Lgnew grew older, he gave up entirely all his expertitions as a sportsman, although he still retained a love and appreciation for the plasure of the chase; but his time was too fully occupicd for him to indulge in this farorite pastime of his arlier manlood.

Dr. Lenew was one of the best judges of horse-flesh that it is possible to become. All his life he had a fondness and admiration for that noble animal, and he could take in at a glance all its good qualities and defects. If he approved of the selection 
of an animal, its purchaser could rest satisfied that it was all that had been claimed for it.

Dr. Agnew had now been in practice for nearly five years, during which time he had been busily engaged in work. He was happily married, and had apparently settled down to his life-work as a country plysician ; but just at this time, through the instrumentality of his marriage, he gave up his profession for a time, and unconsciously mapped out for himself a totally different career, even, from the new work which he had undertaken. As he said himself, in his speech at his own jubilee banquet: "Any man who has lived long in this world, and has taken a thoughtful retrospect of his life, must be forced to confess that the influences and forces which have conspired to mold his character and to shape his destiny are most mysterious indeed. Plans constructed with infinite care have miscarried; fondlycherished hopes have suddenly been crushed with a shock; glowing anticipations just about to become realizations are dissipated in a moment into thin, viewless air, like earth-mists before the morning sull."

The details of this change in the life of Dr. Agnew, which gave him eventually a career undreamed of at this time, are given in the next chapter. 


\section{C'HAP'TER III.}

\section{The Store of 1)r. Agrew's Business Venture.}

TuE story has been told that Dr. Agnew, discouraged by his prospects in medicine and feeling himself unfitted for its practice, determined to give up his professional life and go into business. This incident has often been eited as an illustration to encourage the medical graduate of to-day who sees in the future no opening for himself; its application is obrions. This story is partly true, and partly false. Dr. Agnew did not give up the practice of medicine because he felt that he was intitted for it, or because he felt that there was no finture in it for him. but because he thought he saw a much greater opening in another direction. There came an opportunity to him of immediate advancement, in his early professional life. which he did not dare ignore, although it is true that his consent to it was most reluctantly given; for his love for medieal work. as he has said himself, was inborn, wronght into the rery fibre of his mental organization.

His father-in-law, Samuel Irwin, was a well-known and prosperons iron-founder of the early part of the century. He had furnaces on Bush River, near Baltimore; at Pleasant Garden and at Washington Forges, near Bellefonte, in this State. 'The firm in Baltimore was Irwin \& Patterson, - the Patterson being the brother-in-law of Jerome Bonaparte; the firm name. in Ploanut Garden was simply. Samnel Irwin; in Bellefonte it was Irwin \& IIonston. Ife had, in addition, a number of large stores. to supply the necessaries of life to his workmen at these different points. Is he grew older, the care of these industries devolved more and more upon his sons. until at his death they assumed control of his large business. Then it was that Dr. Agnew was invited to enter the firm, to represent the interests of his wife. 
His progress in practice in the country had been fairly successful. He had been cordially received by the people, on account of the pleasant memories which had been left by his father, who had been a practising physician in this locality for many years; but, of course, practice in the comntry, as well as elsewhere, is, at the outset, not particularly lucrative to a young man. It requires years to establish the confidence and to acquire that acquaintanceship which lays the foundation of a physician's success. His principal competitor was Dr. Nathaniel Sanmle, who at that time had reached an honorable old age, having earned a reputation which made him the leading practitioner of the region,-—skillful, capable, and honest.

Consequently, this admission into the partnership of a large manufacturing concem was a flattering opportunity to the young country practitioner; although, knowing his own nature so thoroughly, his consent was given reluctantly. Therefore, in $18+3 \mathrm{Dr}$. Agnew relinquished all idea of continuing his medical work, and joined his brothers-in-law in the management of the iron-works at Pleasant Garden, Chester Comnty, P'ennsylvania.

At this time that great revolution in business methodsthe logical sequence of the introduction of new agencies in the mercantile world-was just beginning. The electric telegraph, the railroad, the extended use of steam as a power, and the invention of improved machinery were all making new conditions in the industrial world. New competitors were springing up everywhere in every business; competition was becoming eloser and keener; those industries which were disadvantageonsly placed in any way, in the new order of things, were being pushed slowly but inevitably to the wall.

It was the mill-race against the steam-engine, the Conestoga wagon against the freightecar. No such revolution lad been known before in the business world; consequently, its forces and powers were not quickly grasped or utilized by all the business men of the period. Because their fithers or grandfathers had made money in the old way, many clung to their old loca- 
tions, old machinery, old methods of business, old means of transportation. It was this spirit which drove the great whaling firms of New Bedford. bringing their oil from far-distant, perilous, and uncertain sources, to attempt to compete with the great oil-wells of Pennsylyinia, spouting their thousands of gallons daily. 'The result was typical of the conflict everywhere. The great fortunes of the whalers ${ }^{1}$ melted away like mist before the summer sum, in the fierce but unequal competition with the penniless but clear-headed men who saw the real outlook of the finture. and who were straining every nerve to get money to buy oil-lands. This struggle went on in every business; the simple rules of political economy were being fought against in rain.

The wrecks of this terrific storm still strew the country, forming its only rums. How often, in a drive through the shaded roads, alongside many of the tumultuous streams of central Sew York or Pemsylvania, can be found the romanticallydeserted mill or moss-covered factory which once echoed to the ceaseless hum of industry! These romantic spots, now so suggestive of legend or story, were made by the practical demands of commonplare, commousense business. It is stern reality, curionsly enough, that makes the romance of this world.

Among other industries, there occurred no greater revolution than in the iron business. Formerly, the iron was found in small quantities in isolated spots and hauled by wagon many miles to the foundry or the rolling-mill, where it was smelted by spercially prepared charcoal or by coal brought from a distance. The manner in which the work was done, as compared with the tremendons modern methods. was mere child's play. Often great works were built which depended on the iron found in the peat of swamps along the coast-line. "The ruined village of Allaire," near spring Lake Beach, New Jersey, with its rows of empty houses opening on grass-grown streets, and its gaunt, huge fomdry bnildings, with their gaping windows, forming as

\footnotetext{
II justice, it must he stated that some of the whaling firms saw the temporary nature of their business long before its destruction.
} 
true a deserted village as ever was painted by Goldsmith, is a typical example of this lind.

In order to see the position of the Pleasant Garden IronWorks in the business world of the period, and the varions agencies which were at work, it is necessary to present a brief outline of the history of iron-making, and the various sudden revolutions which have occurred in its history. As far as can be determined, the first iron-works in Pennsylrania were established in 1718, by Thomas Rutter, near the present city of Pottstown.

Of course, the works of the eighteenth century were of the most prinitive character; such a works, in those days, being called a "bloomary," or Pool forge. The forge, at that time, occupied a far more prominent position than it does at present, being the great means by which pig-iron was converted into marketable articles. This work, which is now done by the rolling-mill, was hammered out by hand on the forge, the product being called "bloom," deriving its name from the fact that when hammered into shape on the anvil, it was the flower of the metal, gaining its name from the German term "blume," a flower. This product was made from cast- or pig- iron, or even directly from the ore. Until 1838, all iron-furnaces in the United States, with the exception of a few coke-fumaces, used charcoal as fucl. All fumaces, at this time, were blown by water-power, and the blast was always cold.

In 1838 anthracite or stone coal first came into use as fuel for iron-works. Its introduction into the manufacture of iron gave a great impetus to the industry ererywere, and it was followed by the establishment of many other furnaces in other parts of the country. Raw bituminous coal was used as fucl for the same purpose in 1843. The first Lalie Superior iron-ore used in a blast-furnace, curiously enough, was brought by lavid and John P. Agnew to their furnaces at Sharpsrille, Penusylvania, in 1853 .

At this time, outside communication and the means of trans- 
portation being limited and equally good to all, and the demand coming from no great distance, the importance of being accessible to the marliet was not appreciated. In those days there were no railroats or canals in existence, and every one was obliged to cart his merelandise by wagon. In consequence, thene foreses were placed in locations which, nowadays, seem out of the way.

One of the farorite situations at this time, for an ironworkis. was in the range of hills ruming down from the Allewhenies to the sea, extenling through the pleasant, fertile farmlinds of C'hester Comnty, on the border of Mason's and Dixon's line. These ranges of high hills afforded two great adrantages: in the first place, charcoal, which was then the great means for smelting iron. Was one of the most expensive factors in the iron industry; consequently, the location of the ironworks in the midst of a densely wooded region afforded access to a large and partically inexhanstible supply of fuel. In the second plice, the waters of the rapid streams which were found among these hills afforded the great source of power. The ariangement of the land by nature was such that dams could be built and fine water-supplies obtained at a very moderate outlay of money.

As time wore by, the disadrantages of such a location as that dhosen by samuel Irwin for the site of his iron-works, on the Big Elli Creck, became more apparent. 'The Reading Railroad was tinished in 18:38; the great Pemnsylrania Canal, with its Portage and Colmmbia Auxiliary Railroad, was opened for traffic in 18:34; and by 1840 communication had been opened with the (ireat Lakes at Cleveland, by means of the Bearer River and the Ohio C'anal. In 1840 the State of Pemsylvania had 9it miles of canats and 953 miles of railroads; thus, it (an be secm that the means of transportation were being rapidly extemerle

Forese at this time, were begimning to stop the manufacture of bar-iron, leaving its production to the rolling-mills, 
forced by the many improvements in the various processes which were made continually in the manufacture of iron; in 1836 furnace gases were first utilized for increasing the heat of the fuel; in 1838 the hot blast came into use.

The business life of the iron-manufacturer, at this period, was particularly hard and precarious. His business was open to such disadvantages and losses that it early dawned upon the government that protection must be given to this branch of industry; in consequence, in 1836, corporations for the mining and working of iron were farored by legislative act. This was necessary on accomnt of the panic which was approaching, and because of the strong alien influence at work, exerted by the English iron-workers, who were at that time in a more prosperous position than their American competitors. It has been stated, on good authority, that scarcely an American firm engaged in the iron industry made money between the years 1840 and 1850 , and countless numbers of firms were forced to succumb.

The iron industry of Pennsylvania lias always been one of the most important and typical features of this commonwealth. The iron-workers of Pennsylvania were most influential in the settlement of the State. Except for the thinning out of the forests to obtain the charcoal for their furmaces, there would not have been a sufficient number of acres cleared to have allowed the farmer to do his work satisfactorily, for the farmer did not have sufficient inducement to do this work for himself. In consequence, agriculture would have lagged. The forgemen and furnacemen, in the history of Pennsylvania, were never far behind the pioneer with his rifle. If it were not for the existence of forges, furnaces, and rolling-mills, also, there would not have been so much inducement for the improvement of the means of transportation. Inistory shows that canals were first used for this branch of industry. Anain, the necessity for a larger quantity and a better quality of fuel led the way to the introduction and utilization of anthracite coal. The history of the coal industry goes hand in hand with that of iron. 
The panic of 15:35, which was followed by a period of intense financial depression throughout the country, was felt most severely in the iron industries. It handicapped the iron-workers, who were already at a disadvantage in competition with Great Britain. The amomit of pig-iron produced fell, in one year, to 233.000 tons, from 390,000 tons of the year before. It was only by the imposition of a high protective tariff, by the organization of corporations, with large amomnts of capital to draw upon, and by many farors of legislative action, that the iron business was nursed until it grew to its present colossal proportions.

The Pleasant Garden Iron-Works was a most perfect example of the old-fishioned method of producing iron. In 1811 Ellis Passmore built a forge on the Big Elk Creek, five miles sontheast of Oxford, and two and one-half miles southwest of New london, in Cliester County. He also erected, in this beautiful valley, a handsome colonial residence, two and onchalf stories high, built of stone, and a typical example of this pretty style of architecture. Shortly after this time he sold the works to his brother-in-law, Samuel Irwin. Mr. Irwin conducted these works most successfully, and at his death, in 1842, the business had grown until there was a large collection of buildings here, in which the work was carried on, or in which the worlimen lived.

When I)r. Agnew was admitted to the firm, some of these disadrantages were alrealy folt. Realizing that they must keep up with the adrances and improvements in the iron induiry, they added a rolling-mill, at the expense of many thourand dollars. in 1845 . Their location had been excellently -clected. It is ronceded to-day to be one of the best water-rights in the state. Tlese dam supplied a water-power dependent on a lake extending backward for a mile and a half; but by this time the worlis were far from railroad, river, and canal; its ore luad to be hauled from a distance; its fucl was old-fashioned and sccond-rate; its power uncertain and weak, compared to the newer sources of power. 
The transformation occurred almost in the twinkling of an eye, from the time when the old-fishioned iron-works in the densely grown woods on the babbling streams of P'ennsylvania made its owners' fortunes, to the period when an iron-works required, for its successful continnince, three vital ficctors,the cheapest fuel, the most extensive comnections by rail and canal, and the best ore. The change took place with such lightning rapidity that it startles even the observer of to-day studying its phenomena.

It was just at this time that Dr. Agnew was admitted to partnership, and the firm name became Irwin \& Agnew. IIad he gone into the industry ten years before he would have been successful in it, and America would have lost her greatest surgeon. How inscrutable are the ways of Providence!

The iron used at Pleasant Garden was not mined here, but was hauled by eight-horse teams from Port Deposit, Elliton, Perryville, and other points at a considerable distance, necessitating, of course, a considerable expense in the manufucture of its products. The iron-foundry was in a most unfarorable natural position to compete with the newer mines in better locations being worked everywhere. These influences had not been felt in the original growth of the concern.

To the credit of Dr. Agnew's business sagarcity it must be said that the circumstances of the business made it such that it had to struggle at this point, without the possibility of seeking a newer and more farorable location. Many different interests were involved, and no concerted action to remove wals feasible.

The firm of Irwin \& Agnew made a long and cletermined struggle against unequal forees. In this they were somewhat handicapped by the fact that the resomres of the firm had been lost to a considerable extent in various ways. After the maintenance of the firm for three years after the admission of Dr. Agnew, they were eventually obliged to succumb, and consequently to assign. During this time Dr. Agnew worked 
with the greatest zoal and intelligence to maintain the sinking fortunes of the cstate. Ile male a desperate attempt to stem the current which was swepping them along; his attention and absorption in business was umelenting day and night, but the firm was too hearily handicapped; it was doomed to failure.

It is difficult now to trace the site of the forges and the rolling-mill, for the buildings themselves have long since fallen to the ground. With the aid of a guide, however, it is possible to see where the different buildings stood, although now only masses of crumbling stone mark the locations. The dam which supplied the water-power gave way about ten years ago; in strength and size it had been the wonder of the neighborhood.

Only portions of the walls of one building remain. At the odge of the road, half-hidden by the dense foliage of the surrounding trees, stands a solitary stone wall, as solidly built as the comer of a prison. It is probably twenty feet high, and forms one of the comers of the old charcoal house, inclosing, probably, one-half of the building. In the deep rault, still shadowed and hidden by this wall, was stored the fuel, from time to time as it was needed, for the forges.

seattered orer the ground can still be found large quantities of iron-slag, which, at the time of the rumning of the ironworlis. lad been discarded as worthless, being full of fragments of charcoal. At that time there was no method to separate the chlareal firom the iron; in consequence, tons of this material had to be discanded. Recently, a method was devised which sepalated the chancoal from the iron, and tons of this worthless inn-slas have been removed from the place; while it lasted, it was funto in demand, for it contained plenty of grood iron.

Curmany cuongh. the rerolutions of time and the requiremonts of latre clays render it possible that this old, deserted site, which mallis the wreck of a large fortune, will probably be agim the serue of industry. The Big Elk is a valuable stream in the manufincture of paper, for paper-mills require water of a certain degree of purity with which to wash their paper. In 


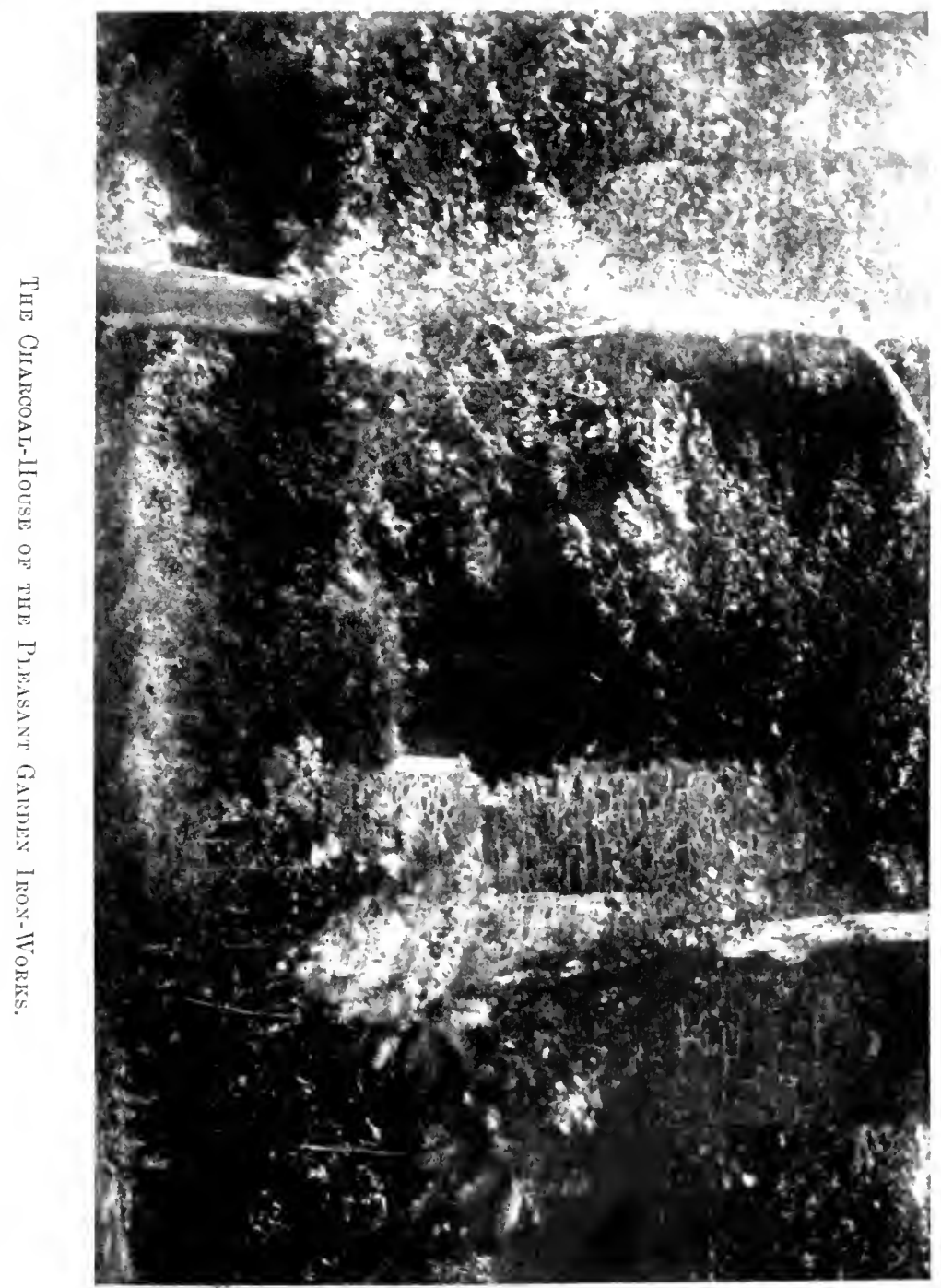


consequence, there has sprung up on this stream a number of paper-mills; the paper which is used in the Philadelphia Pubtic Ledger and the Philudelphice Record is made on this stream, not ten miles away.

Since the projection of a new railroad-the Lancaster Southern-through this region, a branch from the Baltimore and Ohio, locating a station within a mile of this place, there has been good prospects of establishing another paper-mill here; so that probably industry will again be seen at this deserted spot, which, unless ruined by the changing improvements of time, as its predecessor was, should be eminently prosperous.

Dr. Agnew felt keenly the failure of his firm, and, endowed with the same sensitive feeling of honor in business as Sir Walter Scott, determined to make up to his creditors, at the earliest opportunity, all that had been lost. Through his ability to do successful work elsewhere, in another line, he was able to pay back to the creditor's every cent of indebtedness against the firm.

This is the simple story of Dr. Agnew's venture into mercantile pursuits. It has been distorted in many particulars, as have many other facts in connection with his life.

Although it was regarded as unfortmute at the time that the firm should have failed, it was the most fortunate thing that it did occur, not only for the medical world and the general publie, but also for Dr. Agnew himself; for he was undoubtedly intended by nature to do the work which he met subsequently in his professional career.

During these years of hard, unceasing toil it became the custom for Dr. and Mrs. Agnew to make an annual pilgrimage by carriage down into Maryland to spend a few days with his parents. In these expeditions they were joined by his halfsister and her husband, Mr. and Mrs. Davies Wallace, and their daughter, afterward Mrs. Mary A. Falls. It took two days to reach the home of the elder Dr. Agnew, in Baltimore County, but in pleasant weather it was a beautiful drive. 
The second erening found them all at their journey's end, tired and humgry, but the elder Mrs. Agnew was always ready with her cheerful wolcome and a steaming supper for their comfort. Alter supper they talked over the events which had transpired since their last mion mutil it was time to retire; then the family Bible was bought ont and the Psalm-books. All joined roice; if not always in chord, at least it was done heartily. 'Then "Good-night" and "God bless you" were said. In the morning the party gare themselves to their enjorments. Frequently the younger I)r. Agnew would bring ont his violin, on which he was a slillful performer, and discourse sweet music for their pleasme.

'Those were busy days for all. Dimners and suppers through the region were given for them; all the amusements of the Maryland romutry life were brought into requisition.-fox-hunting. ganning, and riding for the men; dinners and risiting for the women.

Just before the party returned home, every one who had shown them attention was invited to the house to a bountifnl dinner. after which the party of children. now in middle age, returned to their Pemerlvania homes, just over Mason's and J)ixon's Line.

Fecling that he had lost a number of valuable years in which he might have been gaining practice, Dr. Agnew returned again to medicine with redoubled energy and power. Consequently, he settled in ('ochranville. which was then a flourishing. enowing village in the contral part of Chester County, a fiw miles south of l'arkesburg. He remained here for seven months. and his snceess was most re-assuring, although he had in the small town a very popular competitor,-a Dr. Windall.

On his return to modicine he determined to make the practice of surerery his life-work. He hatd long been decided to become a smreon; in order to do this, he saw that it was necessily to study anatomy. In consequence, he put into action a long-cherished plan which, unconsciously, changed his 
whole future life, and gave him another wholly different career from any of which he had yet dreamed.

He began to dissect and study bodies sent to him from Philadelphia; but it was not long before this anatomical work threw him into bad repute with the people of the district in which he lived; the country gossips began to criticise the young doctor's methods of investigation, and he became much disliked in the combry for the work which was bringing his future colleague, Leidy, fame in the eity.

This dislike for his work among the country people was increased by several unfortunate incidents. He was in the habit of employing a farmer to remove the bones of his subjects to a neighboring pond, after he had dissected the soft parts. 'This pond was well stocked with eels, which completed the work of cleaning the bones for him,-a process all anatomists know to be extremely slow and troublesome when done by the dissector. 'The bones being cleaned, he was thus enabled to study them earefully.

At this time, unfortunately, there happened to be a fisherman in this region, who supplied the entire comntry with the best quality of fish; his cels, especially, were famed for their size and futness. There was a flavor and a snap about the ecls which this particular fisherman supplied that put despair into the heart of every other fisherman in the county. In consequence, this fisherman's reputation grew,-his eels were in greater demand,-until, finally, he was hardly able to suply ly his many customers with this toothsome viand. The furmer who assisted Dr. Agnew in his anatomical pursuits was among the customers of this prosperous fisherman. Working in his fiekl one day, while the fisherman was passing, the firmer became curious to know where such magnificent ecls conld be found. " Wcll," replied the fisherman, "if you will promise to keep it a secret where I get my ecls, I will tell you; I get them from a pond down here, on your own farm." "What!" eried the farmer, "you don't mean to tell me that you get them from my pond?" It prored too true for the farmer, before whose unhaply vision floated the 
memory of many a hearty meal on these eels. When this story became known, it did not increase the popularity of the young anatomist to any great extent. The neighbors began to investigate this mysterious pond, and, among other relics, fished up a skull with what they supposed to be a bullet-hole through it. Some of the country people-possibly some of those who had partaken too bountifully of the eels,- - suggested that it was some one who had been shot by this too enterprising scientist. Fortumately for all concerned, Dr. Agnew was able to demonstrate to the community that this mysterious hole was made by a trephine, and was done for practice, and not a bullethole at all.

All these incidents, instead of discouraging Dr. Agnew, only intensified his desire to get into a wider field, where he could pursue his labors unmolested by too curious neighbors. Naturally, too, his practice was seriously injured. He relates that after the occurrence of these incidents, while driving along the country roads, it was no uncommon thing for the people of the district to ignore utterly his existence. He determined not to give up lis study of anatomy, although it rendered his future most precarious. He had a wife to support and no one to aid him, yet he did not tum back. Having at last fixed on his course of action, he determined that nothing should deter him from reaching the goal of his ambition.

He looked toward Philadelphia, - the seat of his Alma Mater.-and he decided to make arrangements to go there to carry out his plans.

In consequence, in the spring of $1848 \mathrm{Dr}$. Agnew came to Philadelplia. ${ }^{1}$ Realizing the fact that a physician's prospects are dependent somewhat on his location, he determined not to select his future residence too hastily; in consequence, he lived temporarily with his brother-in-law, William Irwin, on Filbert Street, west of Sixteenth, at that time a very pretty part of the IIn all previous accounts of Dr. Agnew's life the time of his coming to Philadelphia
has been stated as 15.52, or later. 
city, until he could find a suitable residence. The summer, however, came on before he reached a decision, and at this time 1)r. Nathaniel Sample invited him to return to the country, to take charge, temporarily, of the practice of his son, who had been sick for some time. Accordingly, Dr. Agnew went to Sondersburg, ten miles from Lancaster, and spent the summer of 1848 in the comntry. He soon found out that the younger Dr. Sample had been sick so long that his practice had been scattered, and his services were but little in demand. He determined, however, to take the vacation which the opportunity afforded.

A few years ago, meeting one of the citizens of Sondersburg, Dr. Agnew said: "I located at Soudersburg when a young man; I stayed there long enough to know all the roads in that district; but I found that the people around there wanted a better doctor than I was likely to prove, so I moved."

While here during this summer there occurred an accident, the effect of which he earried to his grave, causing the slight limp in his gait which acute observers could always sec. He was driving with Mrs. Agnew one afternoon, to visit some one at a distance, when his horse took fright at a flock of sheep and ran away. In turning a sharp corner in the road the carriage was flung violently around, and Dr. Agnew was thrown to the ground. Mrs. Agnew was carricd for some distance beyond, until, creeping over the edge of the carriage, she dropped out at the back, falling upon her head, inflicting a severe scalp wound. She did not lose conscionsness, however, and, regaining her feet, she returned to seek her husband. It was ncarly a mile beyond where she had been thrown, but she soon found him, stretehed out white and limp on the porch of a neighboring house. She quickly sccured a vehicle and removed him to her mother's home, where he spent nine weeks in bed. His hip had been very severely injured, and he suffered more or less inconvenience from it until the day of his death. As soon as he was well enough to return to the city, they came again to Philadelphia. In the meantime, being unable to select his own location, and 
not wishing to delay any longer. he left the decision to his brotherin-law. This gentleman selected a house on Tenth Street, above Race, to which Dr. Agnew came when he had sufficiently recorered. The location did not meet with the approval of Dr. and Mrs. Aenew at all, and they determined, at once, to select one that would be more congenial. Accordingly, they took a house, temporarily, on sixteenth street, below Arch, where they stayed until they selected a permanent home, which was at the coliner of Elerenth and Hunter Streets, - 16 North Eleventh Street. It this time this selection was a very central and excellent location. It was in the best part of the city, close to the best class of practice, besides being within easy reach of the School of Anatomy, in which he spent later so many hours a day.

He had not been forgotten by many old friends in the city, and he determined to start to work as quickly as possible. I) prived of his fortune by his failure, he wished to find something which would at once make him a comfortable living and furnish him the means of finture advancement. He saw at once the adrantages of such an institution as the Philadelphia School of Anatomy, which was then rapidly dwindling into nonentity. It was just such a chance for which he was looking; it afforded him a means of support and also a means for eduration, fulfillingr a two-fold mission.

It is hard now, in the lapse of years, at a time when Dr. Agnew has hecome the hero in surgery to the American world and his memory an inspiration to his profession, to realize the boldness of his course which forced him eventually to Philadelphia. When he began to dissect in the country, he knew that his course might imperil his future there, but, once eletermined on it. nothing conld thwart him. His position was not one to which such independence was suited. By the failure of the iron-works all his means of sustenance had been given to his creditors; everything had been swept away. This was the only region in which he was well known, by the memories of his parents, by 
his own life-long friends and associates. and by his wife's relatives and friends. He knew every one, and by education and temperament he was suited to these people. In estranging them. he was estranging relatives and friends, and at the same time he was destroying his only means of support without increasing, apparently, his opportunities elsewhere.

When Dr. and Mrs. Agnew came to Philadelphia they had burned their bridges behind them, and the future was a vilst blank uncertainty. Dr. Agnew did not come as the successful surgeon to fill the professorship at a well-known medical school; nor did he come with the prowess of the discovery of some new and wonderful advance in gynecology, by which a hitherto intractable disease was conquered; but he came with youth, health and strength, and a determination to carry out his line of action. 


\section{CHAP'TER IV.}

Dr. Agnew's Connection with the Philadelphia School OF ANATOMY.

ONE of the principal factors in the success attained by Dr. Agnew was undoubtedly the Philadelphia School of Anatomy. The advantages which the training of such a school imparts, with the consequent reputation which is sure to follow the successful administration of its affairs, can scarcely be overestimated. Philadelphia, in many respects wonderfully similar in its methods of life to London, was like it in the possession of this unique school; the English prototype being the Great Windmill Strect School, of London. This school, founded in 1770 by William Hunter, which boasted such names as the Hunters, Ilewson, Crnikshank, Baillie, Wilson, Brodie, Bell, Shaw, and others, came to an end in 1833, after an existence of sixty-three years, - a period which has been exceeded by its American companion.

The Philitdelphia School of Anatomy, established as an independent school, without the dignity or privileges of a chartered institution, without the prestige of the collection of wellknown names as a faculty, without the privilege of granting diplomas or degrees, has outlasted many larger and more pretentious institutions. This school must not be considered as in any sense a "quiz cliss," although it performed some of the duties of a qui\%. It was an independent school, doing original work in demonstrations, teaching, and dissections. It has always becu remarkable for the chinracter of men it has attracted as teachers. In nearly cvery instance of change in its long and varied existence, it has depended, for its popularity and usefulness, more or less upon the ability and reputation of one man.

The undertaking of such a school meant the greatest risks to a medical teicher, but it also included the greatest prospects 
of success. Failure meant financial loss as well as the acknowledgment of defeat, undoubtedly closing further avemes of advance in the line of medical teaching. Success, on the other hand, meant the gathering of a large class of enterprizing and enthusiastic students,-the most congenial happiness in the world to a real teacher. It meant, also, considerable financial return ; but, far more, it opened quickly and thoroughly future prospects. It attracted attention from all quarters. The school stood as a stepping-stone to professorships in the regular medical colleges. This is shown by the fact that nearly every teacher who left the School of Anatomy was called to some important professorial position. It also meant the rapid distribution of pupils throughout the country, with the consequent growth of consultation practice. In short, the Philadelphia School of Anatomy could be an element for great good, or for great evil, in the hands of its teachers.

The successful prosecution of a school of the style of the Philadelphia School of Anatomy was dependent upon a number of factors. It required the immediate presence of several large medical schools from which it could draw its students. In addition to this, it implied a lack of strength in the dissecting courses of these regular chartered institutions, for it showed that the attractions of the school were greater thin the attractions of the colleges. At the height of its prosperity it was the custom for the medical schools in Philadelphia to charge each student for each branch in which he receired instruction, and hence many students preferred to receive their anatomical education at this school; students being permitted by the authorities of the various colleges to do their disserting wherever they desired. This gave the opportunity for opening such a school. Sulsequently, this privilege was withdrawn; but even after the withdrawal of this privilege the school held its usual attendance.

With the removal of the Medical Department of the University to West Philadelphia, with the strengthening of the Jefferson Medical College and the Dental Colleges, howerer, 
such a school must nece-sarily deteriorate. It is no criticism on the later teachers of anatomy in this school to say that the importance of this institution. als an independent educational factor in Philadelphia medical circles, has become less. The conditions of medical teaching are so different at the present time that this is a natural sequence.

The demonstration of anatomy and the dissecting which were done in this school were intended to be eminently practical in their nature. While it was the intention of the lecturers to present anatomy in as scientific and thorongl a manner as possible, at the same time the subject was tanght for use to practising plysicians. The work done by Dr. Leidy at the Eniversity of Pennsylrania, and that done by Dr. Agnew at this schnol, stind out as typical cximples of the two great methods of tearhing anatomy. Dr. Leidy dissected as the eminent scientist. Whose rast knowledge of comparative anatomy and its allied branches was constantly drawn on for record and comparison. On the other hand. Dr. Agnew dissected as the practical sureon, whose intention it was to use his linowledge of anatomy. and teach others to use theirs, for operating. With that clearness which marked his entire life-work, he saw, when he knowingly incured a second defeat in the comtry, that anatomy is the mother of successul surgery, and he became the the great anatomint in order to become the great surgeon. $\mathrm{He}$ went so lar in this belief as to state that he believed a surgeon conld not berome pre-eminent muless he had spent a number of yast in the actual demonstration of practical anatomy.

This school. which stands mique in medical history in this combly. Was opened in Marrh, 1820, as the private anatomical school of I)r. Jason Valentine O'Brien Iawrance, muder the title of the "Philadelphia Anatomical Rooms." It started at the location at which it stood for fifty-fire years, at the upper end of Chant Street, whirch was then called College Avenue. The buikling in which the school was carried on stood on the north side of the strect. At rarious times the building adjoin- 


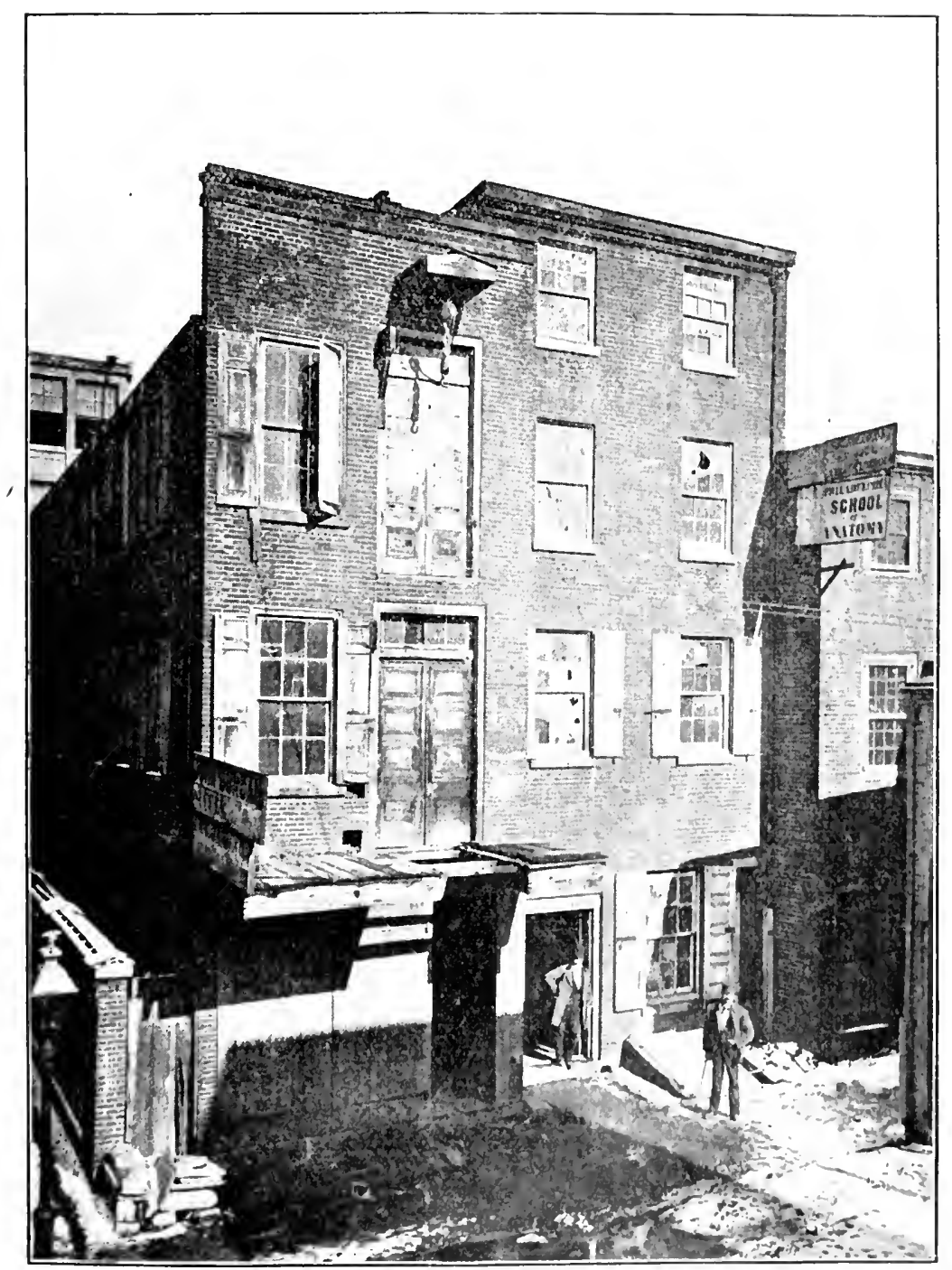

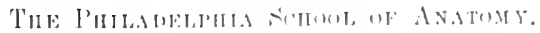


ing to the westward was utilized in addition. It remained in this location until 1875, when the government took the ground on which the easternmost building stood as a portion of the site for the new post-office.

The location of the School of Anatomy, as selected by Dr. Lawrance, was an excellent one. It was within a stone's throw of the University of Pennsylvania, and it happened also to be close to the Jefferson Medical College, which was started at a later date. When the govermment seized the eastern building, as a portion of the site for the new post-office, it left the other building untouched. It stands to-day, a solitary and deserted memorial of the former school. It is unchanged in apperarance, and the old sign, which can be seen on the left-hand side of the illustration, still remains.

At the beginning of the present century, in Philadelphia, it was the custom of well-known physicians to have private dissecting-rooms for their office pupils, not depending entirely upon the anatomical rooms of the University of Pemsylvania. In 1818 Dr. Joseph Parrish opened a private dissecting-room in the rear of Christ Chureh, and in 18:2 Dr. Thomas 'T. Hewson opened another over his stable on Library Strect. next door to the present Custom House, remoring it subsequently, in 1829, to Blackberry Alley, in the rear of his house on Walunt Street, above Ninth. Dr. George McClellan had another private dissecting-room on Sansom Street above Sixth, and a fourth existed on Eighth street abore Jayne, which was then called Lodge Alley.

All of these schools differed from the Philadelphia School of Anatomy, in that they were ephemeral in chancter, and were intended principally for the instruction of the office students of their proprietors; while Lawrance, on the other liand, opened his school for all who cared to come, and so established an institution which has educated thousands of students and scores of teachers for their life-work. Tradition says that lawrance was an unusually brilliant teacher. Ile was bor's in New 
Orleans in 1791, and gradnated at the University of Pennsylvania in 1815. Ile returned to New Orleans, and began the practice of medicine there, but, thirsting for the advantages he had found in Philadelphia during his student life, he returned in 1818, and at once resumed his scientific labors. At that time the Lniversity of Penusylvania, which was then the only medical school in Philadelphia, closed its doors from April until November.

To fill out this long vacation Lawrance gave a course on anatomy and surgery, which began in Mareh, had a recess in August, and ended in Norember. He gare six lectures a week, and his personal qualities, as well as the ease and clearness of his style as a lecturer, made his school a decided success. In the fall of the same year he became assistant to Dr. Gibson, who was then l'rofessor of Surgery in the University, and in 1822 he was also made assistant to Dr. Horner, then Adjunct Professor of Anatomy. He was also surgeon to the Philadelphia IIospital. He did not live long to conduct his school, for, while attending the poor in the Ridge Road district, during an epidemic of typhus ferer in the summer of 1823 , he was attacked by the disease and died, at the age of 32 .

1)r. Lawrance was a diligent writer; he left behind him over three thousand pages of unpublished manuseript, much of it intended for use in a projected work on pathological anatomy, -a subject then very much neglected in America. After Dr. Lawrance's death the school patsed into the hands of Dr. John 1). Gickman. Dr. Godman was also from the South, having been bom in Annapolis in 1794. He studied medicine at the Eniversity of Maryland, and soon atter his graduation, in 1821, he was appointed Professor of Anatomy in the Medical School of Ohio. He came to Philadelphia in 1822 , retiring from practice in 182:3, when he began to teach in the Anatomical School. The first winter he had a class of serenty students. As was the custom for many yars afterward, he gave three courses a year, viz.: The autumn course, twice a week, from September to 
Norember; the winter course, four times a week, from Norember to March; and the spring course, twice a day, with a view to graduation, from March 1st to A pril 1st, the remainder of the year being a vacation from teaching, but devoted to work. The fee was $\$ 10$, the same as it was later, although but two annunal courses were given subsequently, lasting from October to March and April to October, with a recess in July and Angust.

Dr. Godman's lectures were characterized by simplicity of langnage, directness of statement, and fertility of illustration. It was his invariable habit to clissect before the clins while he lectured, no previous dissection, however incomplete, having becn made, - a method which was only practical before the introduction of the use of chloride of zinc, which hardens the tissues too much for such rapid work. He frequently used bodies for dissection which were in quite advanced stages of putrefaction.

In 1824 he established in the school a reading-room sup)plied with text-books and joumals, and, not long after, he intended to enlarge the sphere of the school by adding associate lecturers. Accordingly, he invited Dr. R. E. Griffiths, alterward of the University of Virginia, to lecture on practice and materia medica, and Dr. Isaac IIays on snreery and the cye, lecturing himself on anatomy and surgery. This programme was never carried ont, howerer, for in 1826 the widely-spread fame of Dr. Godman had called attention to him so prominently that he was called to the Chair of Anatomy in Rutgers Medical College, then established in New York (ity. Lufortumately. his health broke down during his second course at this sehool, and, after vainly traveling in seareh of health. he settled in Germantown, where he died in 1830 . He al-o was a roluminous writer. In 1825 he became one of the colitors of the

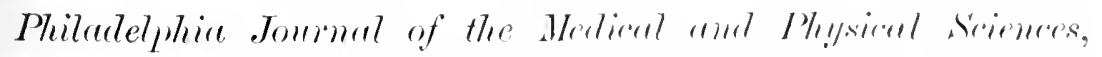
which was enlarged in 1827 , by the agreement that the protession in New York would support the jomrual if it dropped its local name, which it did, beconing the American Jonrmen of the Medicul Sciences. 
When 1)r. Godman went to Rutgers College, in 1826, he was suceceded by Dr. James Webster. Dr. Webster retained the school for four years, when, in 1830, he was called to the Chair of Anatomy in the Genera Medical College. Althongh not so polished a man nor so industrious a worker as Godman, he was an excellent teacher and a good anatomist. He was thoronghly deroted to the interests of his class, and when there was greater difficulty than usual in getting subjects, - a chronic complaint in dissecting-rooms, - - he sat up night after night to see that neither the University nor any private room should obtain them until he was supplied. After Dr. Webster left the school its doors remained closed for a year, making the only break in its history until $18 \%$.

ln 1831 1)r. Joseph Pancoast reopened the rooms, three years after his graduation from the University of Pennsylvania, and in the seven years which he spent in lecturing and working here he laid the foundation of his subsequent career as anatomist and surgeon. He gave the usual three ammual courses which Godman had established, but no other lectures were given in the building during his administration. In 1838, following the usmal custom of the teachers in this school, he went to Jefferson Medical C'ollegre as Professor of Anatomy, in which position he won world-wide fame. After Dr. Pancoast was elected to Jefferson Medieal College he was succeeded by I)r. Justus J)unott, who leetured in the school alone for about three years.

Until 1839 the " Philadelphia Anatomical Rooms" consisted soldy of the east building, the adjacent structure containing a capenter-shop and warehouse; but in 1839 the two buildings contained rival schools, for Dr. James McClintock then rented and fitted up the western building as a lecture-room. Dr. MeClintock had started a dissecting-room the year before at the southeast corner of Fighth and Walnut Streets, and called it the "Philadelphia School of Anitomy"; this was the first time this title had been used by any school. His neighbors complained so rigorously to him, on account of the odor coming from his 
rooms, that Dr. McClintock moved to Chant Street, next door to the older school. Here he gathered a rery large class by his brilliant demonstrations, remaining here nutil 1841, when he was elected Professor of Anatomy in the Termont Academy of Medicine, afterward called the Castleton Medical College. He was sncceeded by Dr. Jonathan M. Allen, who had been a former office pupil and subsequently his assistant. Dr. Allen joined forces with Dr. Dunott, after Dr. McClintock's removal from the city, and they occupied both buildings, taking the new title of the "Pliladelphia School of Anatomy."

It has been claimed, by good authority, that Dr. MeClintock founded the Philadelphia School of Anatomy, This statement is a mistake. He founded a school which he called the "Philadelphia School of Anatomy," and which was subsequently merged into the older school, giving it its new title; but by the Philadelphia School of Anatomy is moant, undoubtedly, the original school which was established in Chant Strect in 1820 by Dr. Lawrance, and which stood on that site for fiftyfive years. The title, "Philadelphia Anatomical Rooms," clung for many years as an explanatory sub-title. Shortly after this Dr. Allen was left in sole charge of the school.

In 1842 Dr. William R. Grant. who had been Demonstrator of Anatomy at Jefferson Medical College, held the western building for a year, when, becoming Professor of Anatomy and Physiology in the Pennsylvania Medical Collegre, he relinquished it to Dr. McClintock, who retuned to Philadelphia and occupied the western building again, from 1843 to 1847 .

In 1844 Dr. McClintock enlarged his school, having lectures on practice by Dr. James X. McCloskey, and on materia medica by Dr. Jackson Tan Starem. Dr. Mrclintock in 1847 secured the charter of the Philadelphia Medical College, and left the School of Anatomy. From 1847 to $185: 2$ Dr. Allen assumed control again of both buildings. At this latter date he also left the school forever, being elected Professor of Anatomy at the Pennsylvania Medical College. One incident is remarkable 
to note which occurred during his administration: a woman dissected in the sehool as a medical student, probably, for the first time, - the date being 1843 or 1844 . During the early part of this decade the school received its most famous scholar of anatomy. Dr. Joseph leidy. Ite was a pupil here for some time during the régime of Dr. Mcclintock.

1)r. Allen was succeeded by Dr. Agnew in 1852, who held the responsibility of the school for ten years. When he cutered the school, as he has stated in one of his addresses, "that single front bench afforded ample accommodations for $\mathrm{my}$ audience." This was strictly true, for the records of the school show that there were but nine students when he began lecturing there. For many long years he toiled patiently and unceasingly, spending from twelve to eighteen hours a day in the dissection of that marvelons human structure which he learned to know so well. His industry during these rears ma be judged by the fact that. in addition to his dissections and practical work, le lectured five evenings a week from September 1st to March 1st, and three times a week from April 1st to August 1st. The school naturally prospered, until he was obliged to enlarge its calpacity, throwing the small room on the third story into the lecture-room, to accommodate the throngs of students who gathered to see and hear his lncid demonstrations. In 1854 1)r. Annew altered the second story of the eastem building, and started the Philadelphia sihool of Operative Surgery, in which his chasses were also large. While teaching here he published his. "I)issector's Minnulu," his lecture on the "Career of Baron larrey," a ratued and prolonged series of papers in the Merlical amel Surgical Reporter, on the "Relations of Anatomy to surgery and Medicine," and prepared a work on the "Fasciæ of the IImman Body," which, howerer, he never published.

As the school grew in size and importance, Dr. Agnew found it necessary to add demonstrators of anatomy to assist him in his work. Drs. R. J. Barclay and J. R. Sanderson were his demonstrators from 185 to 1859 . Later, they were Drs. R. 
J. Levis, William Flynn, J. K. Kane, and Morris J. Asch ; in 1860 they were five in number, Drs. R. J. Levis, William Flym, D. R. Richardson, J. T. Darby, and Robert Bolling. Later, Drs. James E. Garretson, John W. Lodge, and S. W. Gross ${ }^{1}$ were added to this number.

The duties of a demonstrator of anatomy, during Dr. Agnew's administration of the school, consisted in being present each evening, in the dissecting-loom, to aid the students in their dissections, and to demonstrate the different regions of the body. The only remuneration which they received was the adrantage of constantly reviewing their linowledge of anatomy, and the opportunity of practising ligations and studying accurately the parts involyed in hernia, tracheotomy, etc., together with the privilege of attending all the lectures delivered by Dr. Agnew free of charge.

During each winter course Dr. Agnew met his students one hundred and thirty erenings to discuss the high theme of God's master-piece of handiwork. He began the teaching of anatomy by a study of the constituent elements of the body, which was followed by a study of the subject of osteology and syndesmology, in which, as Dr. Agnew humorously stated, his "students" thoughts often embodied the language of the prophet: 'And, lo, they were very dry.", Next rame a study of the apparatus of locomotion, which included the muscular system; then the organs performing the functions of digestion; then the organs of circulation and respiration, and, finally, the organs of special sense.

The School of Operative Surgery was totally distinct from the School of Anatomy. On usually two, and sometimes three, evenings a week, this special class for operative surgery met. On these erenings, lectures were given to explain the surgical

1 By a typographical error, Dr. Aønew was made to state in an address that Dr. S. D. Gross was his demonstrator; the incorrectness of this statement is manifest, for Dr. S. D. Gross, besides being a much older man than Dr. Agnew, was Professor of Surgery at the Jetferson Medical College at this time. 
anatomy of the different regions, illustrated with drawings, skelctons, wet and dry preparations, etc.; for example, first would be studied the surgical anatomy of the femoral artery; next, the various points at which it could be ligated, with the adrantages and disadrantages of each, and the description of the actual steps of each operation. Then each class of five went to its own table with its own assistant demonstrator, and. if the operation was on the common femoral artery, the superficial femoral in Scarpa's triangle and in Hunter's canal were then divided amongst the class, according to a "table of operations." When three operations conld be done on cach side of ach artery, there were more than enough to go round; when a single operation conld be done, such as in tracheotomy, or two, as in limation of the subclavian artery, they were apportioned cruitably annong the different members of the class. The length of the conrse in operative surgery was about sixteen sessions, of two hours each; but the course was always contimued until all the operations feasible on a calaver had been done. Some classes worked more rapidly than others. The number of students ran from six to eight or ten classes, of five each.

The students came from the University of Pennsylvania, Jefferson and Pennsylrania Medical Colleges, and the Dental Collegres, to attend this course of instruction on general, special, and surgical anatomy ; so that 1)r. Agnew's students were by no means confined to one sehool.

'There are many humdreds of graduates of Jefferson Medical College who justly and proudly claim that they were students of 1). Ignew.

Sio crowded did the lecture-room become, under Dr. Agnew's administration. that it was necessary to arrive in good time in order to get a satisfictory seat. As these lectures were given in the evening. so as not to interfere with the courses of instruction at the medical colleges, many were the cases of dyspepsia among the students, who liurried through their evening meal on this 
account. The classes increased each year until they averaged in size about two hundred and serenty students. The school was limited to this number only by the size and capacity of its buildings; if the accommodations had been larger, the classes would have been much larger.

Dr. Agnew inspired his students with an interest in the difficult and dry subject which he taught; so that many who entered the old Chant Street school became zealons and carnest workers, and in after years did honor to their grand old master by becoming themselves distinguished anatomists and surgeons.

Dr. Agnew lectured every evening except Saturday and Sunday, making five lectures a week for six months, averaging one humdred and thirty lectures in each winter course; in the spring and summer course he delivered lectures three times a week for four months. As there are but three hundred and thirteen working days in the year, it will be seen that Dr. Agnew, in delivering one hundred and eighty lectures, lectured, on an average, oftener than once every other day for the cutire year. Of comrse, these lectures were in addition to his disscetions and practical work. As 1)r. Agnew was connected with the school for over ten years, he delivered over cighteen hundred lectures; the lectures in the eleventh year not being counted to offset the few appointments which he did not keep.

The lecture-room of the School of Anatomy was built in imitation of the ordinary lecture-room of a medical college. It had tier above tier of benches, rising so abruptly above cach other that the serenth or highest row was fully twenty feet above the arena. It may be interesting to those who have sat for hours upon the ordinary chinique-room bench, which secms always to be made of boards particularly unyiclding in their texture, to know that these benches were covered with cushions. This unparalleled luxury was the only portion of the "royal road to learning" reached by the embryo anatomists of Chant Strect. In the arena was a revolving table on which the cadaver to be demonstrated could be placed. Orer this was a series of 
lights, so arranged as to throw their illumination over the lecturer and the subject. Ianging in mid-air, by a wire from the ceiling, was a skcleton, which conld be lowered when needed. On a shelf back of the lecturer stood a number of statues, representing, classically. the human form. One was a representation of Herenles, another of Merenry, a third of Venus, and a fourth "The Discus 'Thrower." 'This room was surpringly similar in appearince to the well-known quiz-loom of the Medical Institute, now at 3451 Woodland Arenne, Philadelphia.

The discecting-room was above, in a long, low apartment in the third story. This room is the only trace left of the old school, being situated in the western building, which still stands. Carcful search slows that the rest of the building has been completely altered.

1 curions character which is found in every medical school is the janitor of the dissecting-room. He always has an air of better dars; he is extremely stoical and cynical in his work; and he always commands respect among the students on account of the many stories of his wonderful ability as a hard drinker. That the janitor of this date was of this kind is shown in a resolution passed by the class in $185 \%$. At a stated meeting of the cliss, leeld during the winter of $185 \pi-58$, it was resolved "That in justice to the merits of our firithful janitor, John Campbell, we are compelled to say that, as the genius of the anatomical rooms, lie must be known to be appreciated."

During the winter of $1854-55$ 1)r. Agnew became seriously ill, as the result of a wound received while making an autopsy on a woman who had died of peritonitis. IIe was ill for some time, and during that priod 1)r. William Goodell took charge of the selool, supervising the dissections made by the students.

'Thuroml Dr. Agnew's administration of affairs at the School of Anatomy, the subject of the supply of material was always a difficnlt one. It was necessary for him to be constantly on the outlook to obtain bodies for his students' use, but he obtained them in a perfectly legitimate way; for example, 
during the terrible epidemic of Asiatic cholera in Philadelphia, in 185 , there were so many deaths daily, at the Philadelphia Hospital, that deep pits were dug in the neighboring fields, into which the bodies were rudely thrown. At that time, in order to render these bodies suitable for use, Dr. Agnew would descend into these pits, and, with the sun beating fiercely upon his head, he wonld inject a sufficient number of bodies for his purpose.

Obtaining proper material for dissection is a source of difficulty, in the management of a dissecting-room, which is rarely brought to the attention of the public. This question, which has now been settled legally, - a regular supply, throngh proper chamels, being portioned to the different medical scliools of the country, from the proper officials, - has been, in times gone by, a very burning consideration. From the days when Tesalius was compelled to spoil the gallows of its rictims, hiding the bodies even in his own bed; when Sir Astley Cooper barcly escaped mobbing for the same offense; and Dr. Shippen was assaulted in Philadelphia, in 1765, by a mob, for the same reason, it can be seen that this forms another unpleasant phase of the already hard lot of the demonstrator of anatomy.

The increase of the demand for bodies which came with the advance of medicine, with the lack of supply which existed until within recent years, resulted in the production, especially in England, of a class of people known as "Resurrectionists." These body-snatchers became so expert at their work that they could rob a grave in rery short order. 'The demand became so great, and the price so much higher, that finally the victims were even selected from among the living, and were murdered, in order that they might be sold to the dissecting-rooms. The infamous crimes of William Burke, in Edinburgh, are among the most interesting in criminal amnals. This man killed a number of persons, in order to sell their bodies to the local dissecting-rooms. Similar instances occurred elsewhere, until the authorities, aroused to the necessity of regulating this question, 
passed the "Anatomy Acts." In England, the Warburton Anatomy Bill, enacted in 1832, gave all unclaimed bodies, under certain regulations, to the various schools. This was followed by the passage of similar acts in this country.'

The great mass of ignorant people are so slow in acquiring their knowledge, being generally about a hundred years behind the times, that it is a common belief, among many of this strata of society, that the authorities of certain hospitals murder their patients in order that they may be dissected by medical students. The Philadelphia Hospital has a great reputation for this thing among the negroes of the city; they believe firmly that when they go to this hospital they need never expect to come back alive. In consequence, it is only as a last resort that they apply for admission to this institution.

This ignorant belief, curiously enough, is heightened by some of the conditions of admission in the hospital rules. This hospital is the only regular hospital in the city which will take any large number of chronic ases. Consequently, when a negro falls sick with pneumonia, he can go to the Pemnsylvania IIospital, where, as a rule, he recovers; but, if he contracts consumption, he applies in rain at every other hospital, until he is at death's door, when he is forced into the Philadelphia Itospital. from which his non-appearance alive is only confirmation, to all of his friends, of their belief. To show that these are not idle statements, it is only necessary to state that on Augnst 26, 1892, a negro minister, named Moulton, was hanged in Camden, New Jersey, for the murder of an aged colored woman, who was boarding with him. In accordance with this commonly-accepted belief of lilling persons for use on the dissecting-table, he had offered her body, before her murder, to a medical student at the University of Pennsylvania. When anked by the student how he could supply a living per-

1 The history of this outgrowth of medical work, which is iutensely interesting, can be foum in the Londun Lancet: the Life of Sir Astley Cooper; the Life of Robert Knox, the Anatomist: The London Mclical Times and Gazette. ete. Dickens also, in his norel of Our Mutual Frieud, presents a sketch of the life of a resurrectionist. 
son for this purpose, he replied, nonchalantly, that he would "put her out of the way." The ciremustances of the case were reported to the police, but they believed the whole affin to be a joke, and so took no action in the matter until the unfortunate old woman lost leer life.

The School of Anatomy continned to prosper for nealy eight years, until the mutterings of the Civil Wa were first heard, when the old school was the scene of one of the earliest breaks in our national life. For a few hort months its earecr was crippled. and it lost its principal somec of revenue,-its Southern students. A rery large proportion of the medical students of that day, as well as of this, who were attracted to Philadelphia, came from the South and Southwest. In the winter of 1859-60. so much exeitement was ereated in Philadelphia by Jolm Brown's invasion of Virginia. and so much sympathy was shown for him and his adherents. that the ypirit and enthusiasm of the Southern students were thoromehly aroused, and they determined to leave Philadelphia and seek more congenial localities for study. A telegram from Governor Wise, of Virginia, requesting them to leare Philadelphia. precipitated this action. In consequence. hy the middle of liohruary, 1860, most of the Southern students lont Philadelphia in a body, to go to the medical schools in Baltimore and Richmond. This occurred before the people of the North were filly aroused to the fact that a strugele was approathing. It was feared, at this time, that the school would suffer screrely fiom this defection of the larger portion of its sturlents; lut many new students from the South, despite the uncertain condition of the country, came in the fall of 1860 . When, howerer, war was actually declared, the school lost all its Southem patronage.

Dr. Agnew's records of his students, at this time, show only an occasional pupil from neighboring Southern States. Fortunately, howerer, the school was not injured at all, financially, for, of course, the fees of the term during which the defection took place were already paid, and, as compensation for the loss 
of these students, the demands of the war sent, in their places, students preparing for field service; so that the classes continued about the same in number.

The receipts from the School of Anatomy, when it was in successful operation, were sufficient to repay a physician moderatcly for lis work. The uniform fee for each course was $\$ 10$ from the starting of the school to the present day. There were two courses through the rear; so that the receipts from the school, with several hundreds of students, were considerable. The extent to which the school could attain in its financial returns is shown in the case of Dr. McClintock when he had the school. from 1838 to 1840 . His receipts from his winter classes for 1838 to 1839 were $\$ 190$. His receipts from his spring course were $\$+0$; so that he made from his lecturing, for the year, $\$ 230$. The next year, the winter of $1839-40$, his receipts were $\$ 115$ ) for his winter course and $\$ 50$ for his spring course.

As the years rolled by and the school came into Dr. Agnew's hands, the receipts were increased many-fold. It is an easy calculation to see what his income was; but any estimate would be too low, from the fact that he gave two courses in the year, the summer session attracting from twenty-five to fifty students at the same fees as paid for the winter work. In addition, the fees from the School of Operative Surgery, founded by I)r. Agnew, also greatly increased his income. As has been said, his classes in this school raried from thirty to fifty in each conrse, which was comparatively short. At the same time, this was fin below the pecuniary returus for successful work in other professions or occupations.

I)r. Aenew paid $\$ 600$ for this school, which, considering the faret that he had but nine students and but a small number of specimens for demonstration, was a considerable sum. He sold the school to 10r. Garretson for the same amount,-a characteristic stroke of business, -although his students had increased from nine to two hundred and sixtyseven, making, probably, the largest private class, under an 
individual, independent medical teacher, in the history of the world.

In 1862 Dr. Agnew relinquished the anatomical department of the school to Dr. James E. Garretson, who liad been his demonstrator for several years. Dr. Agnew retained the course in operative surgery for a year longer, until he was made Demonstrator of Anatomy and Lecturer on Clinical Surgery at the University of Pemnsylvania. He was succeeded in the Department of Operative Surgery, from $186+$ to 1867 , by Dr. J. M. Boisnot. After two years of successful teaching Dr. Garretson withdrew from the anatomical department, on his election to the Chair of Surgery in the Philadelphia Dental College. In accordance with the influence of the school, Dr. Garretson was not idle with his pen, for he las since published his large work on "Oral Surgery" and a number of charming philosophical and metaphysical reflections, under the pen-name of "John Darby."

In the summer of $1865 \mathrm{Dr}$. James P. Andrews assumed the duties of Lecturer on Anatony, but, his health failing, he was succeeded, in the fall, by Dr. R. S. Sutton. After teaching for a year, Dr. Sutton was suceeded by I)r. Wr. Wr. Keen, who conducted the school successfully until $18 \%$ \%.

From 1866 to $1870 \mathrm{Dr}$. Feen occupled only the western building, Dr. D. D. Riehardson having the lower story of the other for his quiz class, and Dr. II. I cenox Hodge, from 1866 to 1870 , the upper story for his courses on operative surgery; but, in order to accommodate his increasing class, Dl. Kecn was obliged, in 1870 , to obtain the use of that building, and, later still, enlarged the lecture-room by plaring a gallery over his head. While comnected with the school. Or. Keen published many articles, besides gathering the materials for more extended subsequent publications.

In 1873 the University of Pennsylvania had been removed to West Philadelphia. Previonsly the school had drawn its pupils from both the University and Jefferson Medical College. 
It was clear to Dr. Keen that he must become an appendage to one school or the other, for, if he attempted to build at a point between the two schools, he would not receive sufficient support to malie his renture a suecess. Moreorer, at the same time, the grovernment took the ground on which the principal building stood as a portion of the site for the new post-office, and so prevented the possibility of the school remaining where it was. I)r. Keen went so far as to purchase two properties on Sansom Street above Sixteenth as a site for a new school, but, after consultation with friends, he decided not to build. Therefore, on March 1, 1875. J)r. Keen delivered the final lecture in the old Chant Street building. This lecture was appropriately deroted to a carefully-verified history of the old school and its honored teachers.

Dr. Kecn's death-song proved to be, however, only a lullaby. The ritality of the old name was greater than had been expected, for Dr. J. M. Boisnot, one of the old teachers of the sehool, opened another institution under this name at $1022-2+$ I Iunter street, a short distance from the old location, the year after the closing of the school by Dr. Keen. As the sehool was not continued in its original location and the goodwill and fixtmes not purchased, as had been the custom through all the various vicissitudes of its existence, it is a matter of dispute as to what degree of relationship should be conceded as existing. On the other hand, it can be claimed by the later teachers that, as the site of the old school was gone, its scholars and teaching-material scattered, there were no fixtures and good-will to be purchised. Moreover, the new school was started by a former teacher in the original school.

Cindoubterlly, however, this was the most serious break in the history of the school. I)r. Boisnot associated with him, in the latter part of his (areer, I)r. J. M. Barton, who lectured on operative surgery. Jr. John B. Roberts obtained possession of the school in 1878, Dr. Barton continuing his lectures. The new school grew, until it retained a number of lecturers: Dr. 
H. Angustus Wilson, on orthopedie surgery; Ifenry Leffman, on chemistry; J. T. Eskridge, on physical diagnosis; Wm. II. Parish, on obstetrics and gynecology; C. W. Dulles, on renereal diseases; E. H. Bell, on obstetries and gynecology ; and C. E. Sajous, on the throat and nose.

It was from this nucleus that the Philadelphia Polyclinic and College for Graduates in Medicine started, in 188\%-83, at Thirteenth and Locust Strects. After the withdrawal of the staff of lecturers for this purpose, the school again contracted to its original work of teaching anatomy, while its brilliant offspring started on its broader career. The inroads of business finally drove the school from Hunter Strect to Cutlibert Strect above Eleventh in 1883, when Dr. L. W. Steinbach became owner of the school. It wandered from here to the northwest corner of Tenth and Areh Streets in 1883. In 188t the school passed into the hands of Dr. Henry C. Boenning, who holds it at the present time (1892). In 1887 the school again mored, this time to the building of the Third National Bamk. at Broad and Market Streets, opposite the Pemsylyania Riailroad Depot.

It is still in a flourishing location, being now situated in the building of the Medico-Chirurgical College, on Cherry Street below Eighteenth, where it exists in connection with that school and the Philadelphia Dental College; it is. howerer, still an independent school, paying its own way, and holding the privilege of accepting or rejecting the students who present themselves. It draws its pupils still from the Medico-('hirurgical ('ollege, the Philadelphia Dental College, the Cnirersity of Pemnsylvania, Jefferson, the Women's Medical College, and those art stndents from the Academy of Fine Arts who wish to study luman anatomy.

While the Philadelphia School of Anatomy was in no sense a "quiz class," remaining always an independent fictor in medical teaching, yet at the same time it gathered in its train, naturally, the elements which subsequently developed into quiz work. The quiz is a coaching cliss in which the knowl- 
edge of the medical student is reviewed, systematized, and stamped upon his mind. It is generally the ivy clinging to the oak.- - the ground corcred being regulated by the lectures of the professor who is in charge of the subject in the medical school. A large part of the brilliant reputation of the School of Anatomy is due to the men who used its accommodations for this work.

'The first one, as far as can be determined, who established a quiz. thereby enlarging the facilities of his office students, was 1)r. Nithaniel Chapman. In 1817 he associated with himself Dr. IIorner, on anatomy, and they occupied a room over his stable-a rather favorite place, it would seem. for anatomistsin the real of his house, on the south side of Walnut Street, the second door below Eighth. In 1819-20 Dr. Dewees joined them, and, soon after. 1)rs. Hodge, Bell, Jackson, J. K. Mitchell, and. for some time, Dr. T. P. Iarris. This afterward became the ". Icdical Institute," obtained a charter, and erected a building in Locust street above Eleventh, afterward occupied, from 1846 to 1848 , by the "Franklin Medical College." This quiz orenuization is still in existence at the University of Pemsylrania.

in 1818 1)r. Joseph Parrish began a similar association with 1). George B. Wood, and afterward also Drs. Richard Farlan and shocmalier. From this, in 1830, arose the " Philadelphia Asociation for Medical Instruction," consisting of Drs. Parrin. Wood, Samuel George Morton, John Rhea Barton, and Franklin Barche. who were joined at various times by Jacob Liandolph, W. W. Gerhard, Joseph Pancoast, and William Rush. For six gears the association continued its labors; but then, as some grew in years and practice, and others were absolbed hy the colleges, it was dissolved. The "School of Medicine" was a third similar organization formed about the same time, in which were Drs. William Gibson, Jacob Randolph, B. II. Coates. Rene La Roche. John Hopkinson, and Charles D. Meigs. Nearly all of these became professors in the University of Penusyrania or the Jefferson Medical College. 
In 1842 , while Dr. Jonathan M. Allen was at the head of the Philadelphia School of Anatomy, the second "Philadelphia Association for Medical Instruction," generally known as the "Summer Association," was formed for the purpose of giving lectures during the long recess in the colleges from March to Norember. It consisted, originally, of Drs. John F. MIeigs, on obstetrics; Joshua M. Wallace, on surgery; Robert Bridges, on chemistry; Francis Gurney Smith, on physiology; and Jonathan M. Allen, on anatomy. The lectures were giren in the eastern building till about $184 i$, when they changed to the western one, and in 185 t to Butler's Avenue, in the rear of the Jefferson Medical College. Here they continued till 1860, when they disbanded.

In 1845 Dr. J. F. Meigs began to lecture at the School of Anatomy on diseases of children, Dr. I. H. Tucker on obstetries, and in 1850, on his removal to the Richmond Medical College as Professor of Obstetrics, he was followed by Dr. William $\mathrm{V}$. Keating. At Dr. J. M. Wallace's death the surgical lectureship was filled by the appointment of Dr. J. II. B. McClellan in 1851, Dr. Addinell Hewson in 1853, and Dr. John H. Brinton in 1860. Dr. Bridges, although elected to the College of Pharmacy, retained his lectureship on chemistry from 1842 to 1860 , - the only constituent member of the association who remained to its close. In anatomy, when Dr. Allen became Professor of Anatomy in the Pennsylvania College, in 1852, Dr. Ellerslie Wallace, then also Demonstrator of Anatomy, and later Professor of Obstetrics at Jefferson, became his successor.

Dr. Francis Gurney Smith continued to lecture on physiology till 1852, when he was elected to the professorship of physiology in the Pennsylrania College, and was succeeded by Dr. S. Weir Mitchell until 1860. The first lecturer on practice was Dr. Alfred Stillé, who joined the association in 1844 and resigned in 1850 on account of ill health. In 18.5 the became Professor of Practice in Pennsylrania College, and later filled the same chair in the University. He was succeeded by I)r. John F. 
Meigs from 1850 to 1854 , and he again, in 185̃ , by Dr. Moreton Stillé, the brother of Alfred Stillé, and already widely known as the joint author of "Wharton and Stille's Medical Jurisprudence." A career of great prominence was then suddenly cut short by a sad accident. A decomposing subject left in the lecture-room from. Friday until Monday, in July, so poisoned the air that Stillé and sereral of the class were made faint and sick. Stillé still lectured as long as he could, but finally was compelled to yield, went home, and, after a brief illness, died from blood-poisoning. The next year the place was filled by I)r. J. M. Da Costa, subsequently Professor of Practice at Jefferson Medical College. Dr. Francis West lectured on materia medica from 1844 till the last year, when 1)r. James Parrish succeeded him. On diseases of children Dr. John F. Meigs was the only lecturer from 1840 to 1850 , and on medical jurisprudence Dr. Edwand Hartshorne from 1847 to 1849 .

Dr. Da C'osta also gave private courses on physical diagnosis from 1854 to 1863 . Such was his reputation at this time, especially a year before their close, that he was compelled to refuse many anxions applicants, lest the classes should become unwieldy for his methods of personal instruetion.

'l'he front room on the lower floor, and afterward that in the second story, was oceupied by Dr. S. Weir Mitehell as his phissiological laboratory. Besides his lectures on physiology in the association, from $185: 3$ to 1860 , he gave, in 1856 , the first purely experimental course on physiology in the city, and also made in these rooms nearly all of his extremely important physiologiral experiments and discoveries, working with dogs, cats, and copperhead, moccasin, and rattle snakes. Many are the amusing stories that conld be told of this somewhat perilous work with snakes; of the mule and insecure boxes in which they were receired, sometimes a section from the hollow trunk of a tree battened at each end with scanty nails; of the suddenly-discovered escape of a snake or two on more than one occasion, -a dis- 
covery none the less disquieting from the fact that no antidote had as yet been found among the scientific harvest; or of the janitor who, one night, when locking up, being slightly mystified by sundry potations, and treading on a headless snake, that rattled vigorously and struck him with its stump, ran to a brick-pile near by, and, filling his arms with the bricks, let fly at random into the dark room,- - he had more than St. Patrick's aversion to snakes,-and bottles, crucibles, costly thermometers, and two weeks of carefully prepared results were in the morrow's woeful count of cost. Many were the assistants who came, and, not liking the work, quietly disappeared; one of them, howerer, rather hurriedly, for he sat down all unconscious upon a lighted cigar, and, leaning rudely against the snake-box, started them to rattling just as the cigar burned through, when, leaping up in affright, he ran away, crying "I'm bitten! I'm bitten!" and was seen no more.

It can now be easily understood how not so much even as a chip had ever been stolen with such objects in the building, both dead and alive, although the door often went unlocked and the cellar was almost always accessible. Eren a former office-boy of Dr. Keen, of African extraction, conld never be induced to put foot inside the building, alleging that he had "heerd of their layin' for colored boys afore now!"

It is interesting to note that the only thing reported to have been stolen during the régime of Dr. Agnew was a valuable paper which he had intrusted to an assistant, and which the latter had stuffed in the pocket of his orercoat, learing it in the museum as he stepped into the lecture-hall of the school. On returning from his lecture, the demonstrator found that somebody had stolen the coat. He was naturally much more concerned over the loss of the paper than over the article of clothing, and spent a restless night thinking of his loss. Curiously enough, however, the thief had the interest of the school sufficiently at heart to return the abstracted paper by the next morning's mail. 
No more brilliant corps of teachers, perhaps, has ever been gathered in this city than this old "Summer Association." Tucker became Professor of Obstetrics first in Franklin College, and then in Richmond; Keating went to the Jefferson; Bridges to the Franklin College and the College of Pharmacy; Allen, as Professor of Anatomy, to the Pennsylvania College; Ellerslie Wallace, first as Demonstrator of Anatomy, and then Professor of Obstetrics, to the Jefferson; Francis Gurney Smith to the Chair of Physiology in the Pennsylvania College, and then in the University of Pennsylvania; Alfred Stille to that of Practice in Penmsylinia College, and then to the University; Da Costa to the Chair of Practice in the Jefferson; Mitchell here formed that habit of exact scientific observation and sagacious deduction which has giren him a reputation on two continents, while Meigs, McClellan, Hewson, Brinton, Darrach, and Hartshorne have all become well-known hospital teachers and practitioners.

As writers, during this period, few men have been busier. Among the medical books and papers which were the direct results of their labors here, the following may be mentioned: Dr. Tucker wrote his "Principles and Practice of Midwifery." I)r. Alfied Stillé published a part of his lectures under the title of "Elements of General Pathology," while the lectures on "Practice," most carefully and "elaborately written out, have formed the foundation of all those upon the same subject which he has since delivered." Ile also published his "Medical Institutions of the United States" and his " Report on Medical Literature," and with Dr. Meigs translated Andral's "Pathological Hienatology." 1)r. John F. Mcigs published his lectures on the "I Iseases of Children." the well-thumbed book of multitudes of practitioners, now grown to be a most portly volume. Dr. F. G. Smith translated Barth \& Roget's "Manual of Auscultation and Percussion," and edited Carpenter's various physiological works, "Kirlies' Paget's Physiology," and "Churchill on Obstetrics." I)r. Keating edited "Ramsbotham's Obstetrics" and "Churchill on Children." Dr. Bridges edited "Fowne's 
Chemistry" and "Graham's Chemistry." Dr. Hewson edited "Mackenzie on the Eye" and "Wilde on the Ear," and all of them wrote numerous papers, reriews, etc., and practised medicine into the bargain! Truly, they were busy men.

In 1855, during Dr. Agnew's administration, another association was started, which, like the one just named, was called after an older one, already noticed, the "Pennsylvania Academy of Medicine." It consisted of Drs. W. W. Gerhard, Henry H. Smith, D. Hayes Agnew, Bernard Henry, R. A. F. Penrose, and Mr. Edward Parrish, the son of Dr. Joseph Parrish, who lectured on practical pharmacy; the next year they were joined also by Dr. Edward Shippen. For two years they continued as an association of lecturers; then Drs. Gerhard, Agnew, Penrose and Mr. Parrish went on as a quiz association for a year, when they disbanded. Dr. Agnew went on with his usual courses in the School of Anatomy, and Dr. Penrose continued to lecture here on obstetrics until called to the University, in 1863. They were equally fortunate in promotion with the members of the other association, for four of the seven went to the University as professors,-Gerhard on clinical medicine, Henry H. Smith and Agnew as professors of surgery, and Penrose of obstetrics.

Besides these distinct associations for lecturing, numerous other independent experimenters have availed themselves of the facilities afforded by the School of Anatomy for their work.

In 1849 Dr. Brown-Séquard gave his first lecture in America in this school, to Dr. Francis Gumey Smith's class in physiology, in the "Summer Association." It was on the physiology of the nervous system; and during the lecture, with that extraordinary manual dexterity for which he is noted, he cut the anterior and posterior roots of the spinal nerves in some frogs, and demonstrated the cross-sensibility of the spinal marrow by sections of its lateral halves in the guinea-pig. This was followed by a course to the physicians of the city. IIs next course was given in the Franklin Institute. Abont this time, also, Dr. John Hastings, of the navy, gave some lectures 
on yellow fever, -apropos of the then existing epidemic,based on his personal observations during the Mexican War. In 1859 Dr. Samuel Wr. Gross, while one of Dr. Agnew's demonstrators, gave courses on operative surgery and surgical anatomy, and again in 1866-6\%. In 1860, and for some time afterward, Dr. John $\mathbf{W}$. Lodge gave courses in experimental physiology in the summer, and on uninary pathology in the winter. In obstetrics, Dr. J. M. Corse also lectured here. In 1864 to 1867 Dr. J. M. Boisnot, and also, in 1865 to 1867, Dr. J. Bernard Brinton, each gave courses in operative surgery.

When Dr. Keen had charge of the school, Dr. Isaac Ott experimented on cocaine and other poisons, and Dr. H. C. Wood on the physiological action of the alkaloids of reratrum viride. Besides these, the following regular courses of lectures have been girm here: On obstetrics, Drs. F. H. Getchell and W. F. Jenks; on the microscope. Dr. James Tyson; Dr. Hodge gave independent courses on operative surgery from 1868 to 1870 in the eastern building; Drs. J. Ewing Mears and O. H. Allis on bandaging and fractures; Drs. John S. Parry, O. P. Rex, Stanley Smith, and IIamilton Osgood, on physical diagnosis; on renercal diseases, I)r. William G. Porter; on ophthalmology, 1)rs. George C. Inarlan, George Strawbridge, and WV. WV. MeChure; and on laryngoscopy. Dr. J. Solis Cohen. For a number of years, also, the Naral Examining Board examined all their candidates for admission and promotion here. In 1837 Dr. E. G. Davis quizzed on all the branches himself, as also, at first, was 1)r. D. D. Richardson's habit. Dr. Richardson's quiz lasted from 1860 to 1871 . and in the last few years he was assisted by Inrs. Boisnot, Cohen, and Witmer. From 1866 to 1868 1)r. Kieen quizzed with Drs. Dner, Dunglison, and Maury; in 1865-69 with I)rs. Warder, McArthur, Leaman, and Mears; and from 1869 to 1872 with Drs. Hutchins, Allis, Rex, Getchell, Leffman, and Loughlin. In 187t-75 Drs. Wilson, West, Greene, and Osgood gare quiz courses. From 1869 to 
1871, also, the eastern building was occupied by the quizzes of Drs. Willard, Curtin, Cheston, Jenks, Wilson, and Githens.

Such, in brief, is the history of this vencrable school, and of the many teachers associated with it. Orer one hundred teachers won their spurs in its lecture-rooms, formed here their habits of thought, style of lecturing, methods of scientific research, and gained their early fame as writers and teachers, so that thirty-two have become professors in sixteen medical colleges, here and elsewhere, and seventy hospital and clinical physicians, surgeons, obstetricians, etc., of distinction. Thirtytwo books have been written or edited, and many pamphlets and papers of value have been published by its various teachers.

Its assistant demonstrators are too numerous even for mention. The students of this old school can nerer be traced. but this much is known, that, spread all orer the world, doing faithfully their daily work in relieving the suffering, soothing the dying, helping the poor, assuaging the pestilence that walketh in clarkness, improving the public health, adrancing the domain of pure and applied science, teaching earnestly its results to thousands of eager students who, in turn, will swell thir noble ranks, promoting in general the moral and material welfare of mankind, some in lofty, some in lowly station, they will confess that here they first developed their scientific tastes and aspirations; here they were taught to look beyond the lower to the highest and noblest aims of their profession; here they first caught the inspiration that has made them what they are, and here they learned to love this old school and its faithful tachers.

So great had grown the reputation of Dr. Agnew in linter years, and his comnection with the School of Anatomy was so quoted in all accounts of his life, that the public at large and the younger members of the medical profession are inclined to suppose that he was its originator, and that he constituted its only glory. On the contrary, this brief history shows the close comnection between the old school and a large proportion of the medical profession of Philadelyhia. The majority of the 
names mentioned in this brief résumé are famous ones in Philadelphia to-day. Dr. Agnew practically built a new school here, but it was made on the rums of an older structure. He did found, however, the School of Operative Surgery, which put into practical use the kmowledge gained in the School of Anatomy.

So great was the concentration of mind of Dr. Agnew in his earlier years upon his work that those who were his assistants for many years, and intimately associated with him in his daily work at the School of Anatomy, were unable to refer subsequently to any special conversation held during those years which was not related in some way with anatomy or surgery. To Dr. Garretson, who was his demonstrator for several years, Dr. Agnew, at this period, possessed the most unspeculative mind on the subject of religion of any man he had ever met. Distinctions often propounded by Dr. Garretson regarding human hypostoses of body, egro, and soul, as the dissectors worked together over a cadaver, failed always to elicit from the elder any other response than that he was sure of the body and was willing to leave ego to philosophy and soul to church, - a most characteristic reply.

In the later years of his comnection with the School of Anatomy, I)r. Agnew did not feel, however, the necessity for that terrible expenditure of force and energy which had so characterized his earlier work. His practice was growing; he was being called more and more into consultation; his hospital opportunities were increasing; consequently, he derolved the mannal work more and more upon his demonstrators.

Undoubtedly, much of the grace, ease, and sureness with which 1)r. Acnew operated was due to his perfect knowledge of anatomy which he learned in this school. He never had to stop to think out the answers to questions in regional anatomy. IIe reached his conchusions as quickly and as naturally as if he were reading an open book. which justified the statement that he seemed to see the positions and relations of the internal organs of the body as well as if their coverings were made of glass. 
He acquired also a most beautiful and attractive style of lecturing, which drew students because of its naturalness. He learned, as has been truthfully said, to present Nature's truths in Nature's simplicity, without the deadly paralysis of unnecessary words. He learned to go at once to the gist of the matter, and, having seized upon the central point of demonstration, he grouped all the secondary features in beautiful sequence about it. His demonstrations of the surgical anatomy of hernia or the regional anatomy of the perineum will always be remembered by those who were fortunate enough to have been his students, as most clear, concise, and yet comprehensive.

Dr. Agnew, when he relinquished this school, had been connected longer with it than any other of its proprietors, his whole term of service, including his connection with the School of Operative Surgery, being eleven years. Although he had grown famous here, and had been by far its most successful teacher, yet he was only the second to leave it not receiving a professorship. His progress forward had been of the slowest nature. He would not push himself, and, consequently, his advance was not rapid, but it was natural. Other men were pushing rapidly by him, younger and less well known; but Dr. Agnew's progress was satisfactory to himself. He was receiving as much as he felt he deserved; and his reputation was not a hot-house plant, ready to wither at the first chilly touch, but a sturdy out-door growth, which the colds and snows of winter could not affect.

Dr. Agnew's final separation from the School of Anatomy occurred in December, 1863, on his appointment as Demonstrator of Anatomy at the University of Pennsylvania. 


\section{CHAPTER V.}

\section{Dr. Agnew's Early Life in Philadelphia.}

Dr. Agrem's coming to Philadelphia was not an unusual thing for a country physician to do ; for probably one-half, at the lowest estimation, of the suceessful city practitioners of today were country boys. This can be seen by taking a list of the prominent physicians of Philadelphia, New York, and Boston, and ascertaining their birth-places.

To the credit of the Philadelphia physicians of that day, it must be said that Dr. Agnew was received with considerable cordiality. He was known, already, to a large part of the profession in the city; among the residents of the town he had some relatives and many friends. He was not treated with the coldness and neglect experienced by Dr. Sims in New York, although he had no such reputation to sustain him at this time as had that gentleman. On the other hand, he did not come to Philadelphia like Dr. Gross, with the appointment to a prominent position in an important medical school.

IIe had his name to make and his fortune to acquire. His experience as a surgeon had been, as yet, limited. He had done a number of major surgical operations, performing some of them as early as 1840; but he had fallen behind many of his clas-mates in this work, on account of giving up his professional duties for over three years.

Possibly, it was the quiet, mobtrusive, but determined, manner in which he began his new career that caused him to be well treated and warmly welcomed by his fellow-practitioners in Philadelphia. In his early years, as well as later, his career was nerer agrgressive; he forced no one from his place or practice; while his hard and conscientions work won for him hosts of friends and confidence in his abilities.

As years rolled by, his position became easier and pleas(106) 
anter; his practice grew; his consultation work steadily increased, and slowly, but surely, he was forging to the front. By 1860 he was acknowledged to be one of the foremost of Philadelphia surgeons.

Undoubtedly, one reason why his reputation was so firmly established was because of its natural growth. It rested on a foundation of the broadest and firmest description. Ho did not buy his way into a professorship; nor did the influence of his friends or family put him there. Dr. Agnew's progress corresponded to his own ideas and beliefs. He has frequently stated that "promotion, to be permanent and successful, must be of slow growtl.."

He did not attempt to attract the attention of the publie to himself by any eccentricity of conduct, speech, or dress. IIe lid not utilize the newspapers to foree his leaming and attainments upon the reading world. He instinctively aroided such reputation, and always felt a gentle contempt for " new spaper doctors." He realized the hollow mockery of the false position of those physicians whose true qualities are known to the rank and file of their profession, but who win, now and then, from the public a false estimate which sets them on dangerous levels of apprirent competence.

During the decade that Dr. Agnew taught at the School of Anatomy, he was not wholly absorbed by that work. cxhansting and exhaustive as it was; on the contrary, he was quite active in other branches of medical enctea vor:

In all the fields of activity in which he worked. Dr. Agnew's connection with hospital duties forms a larege part of the history of his life.

The greater portion of the most raluable surwical work performed by Dr. Agnew was done in the sureriral wards of the various hospitals with which he was comnerted from time to time. He was connected as surgeon, first, with the Philadelphia Hospital, from 1854 to 1865 ; with the Irills' Eye Hospital, from 1864 to 1868 ; with the Pennsylrania Hospital, from 1865 
to 1871 , and from 1877 to $188 t$. He was surgeon to the Orthopedic Hospital from its inception, in 1868, until 1871, when his increasing duties compelled his resignation, although he remained consulting surgeon until his death. His service at the University Hospital dates from its erection, 1873-74, until his death. In addition, during the Civil War he had a most extensive and valuable hospital experience.

At the majority of these hospitals the attending physician acts in a dual capacity, - as a practitioner in charge of patients, and as a teacher demonstrating the various phases of disease and their treatment to the students. It is customary to have Wednesday and Saturday morning cliniques, at which the different physicians on the staff are given opportunities to perform this latter luty. It forms a great training-school for those gentlemen who are anxious to review and classify their own knowledge and learn to impart it to others.

The variety of operations which he performed during this long period of service and the number of patients under his care were countless, many thonsands of cases being under his charge during these many years of faithful work.

The first hospital in point of time with which Dr. Agnew was connected was the official hospital of the City of Philadelphia, called the "Philadelphia IIospital," and popularly known as "Plockley," from the district in which it was erected. He was elected to this hospital in 1854, two years after assuming control of the School of Anatomy. This hospital, one of the largest in the world, with its four thousand beds, is peculiarly rich in all clinical material. Its fame has spread all over the continent. As such, it is a fortunate berth for the ambitious and enterprising physician or surgeon.

As referred to humorously by Dr. Agnew in his speech at his jubilee banquet, the Philidelphia Hospital had closed its doors to students of medicine in 1845. In the lecture on the "Medical IIistory of the Philadelphia Almshouse," delivered at the opening of the clinical lectures, October 15, 1862, by Dr. 


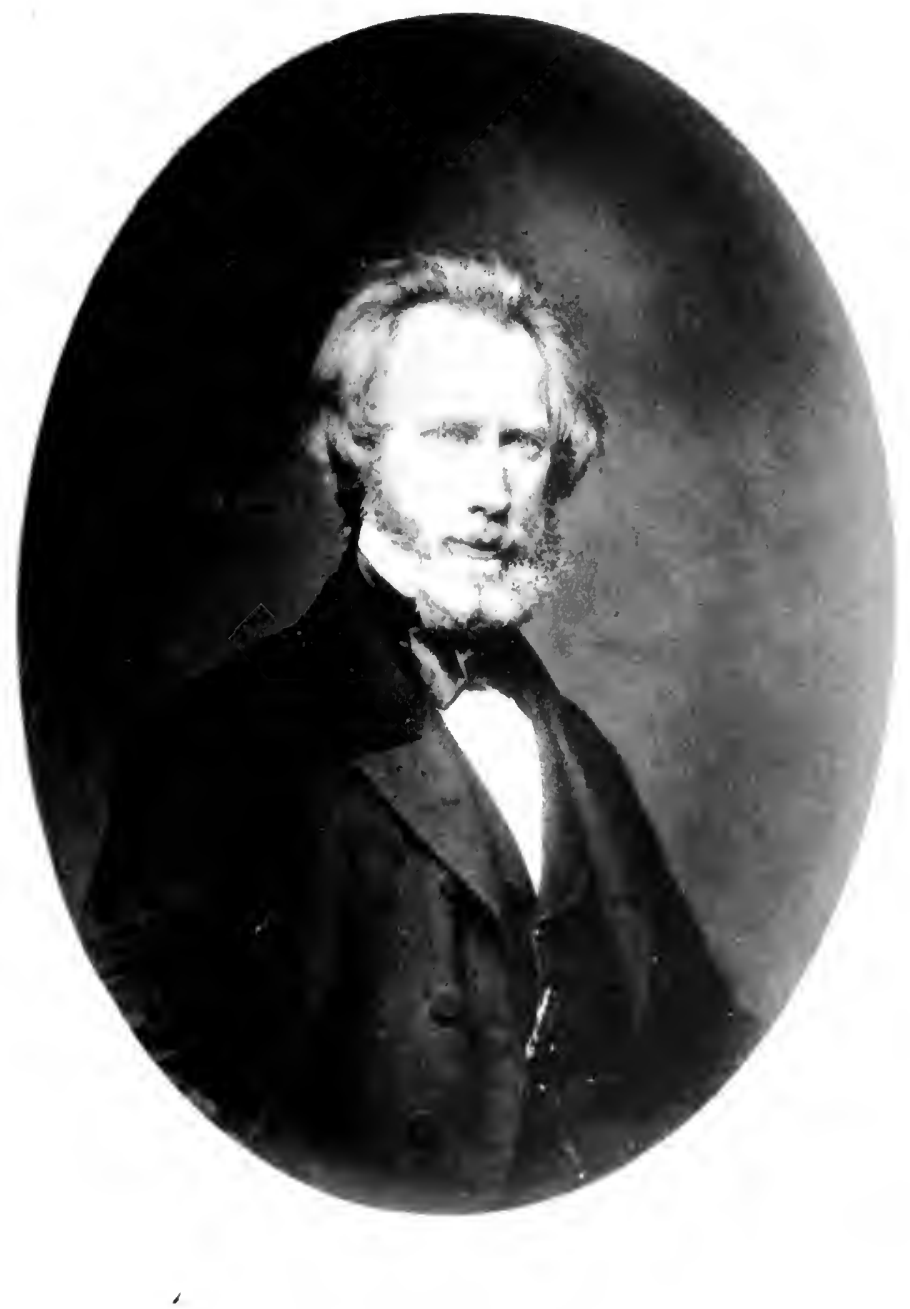

DR. AONEW 1 N 1858 . 


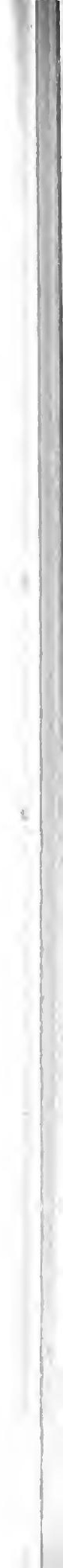


Agnew, and published by request of the Board of Guardians, the following amusing account of the incident which caused the abolishment of clinical instruction at the Philadelphia Hospital for nine years is given :-

"The 30 th of June, 1845, is somewhat remarkable in consequence of the culmination of the trouble which had been developing for some time. The Resident Physicians were boarded at the table of the steward, where, as I understand, in consequence of the want of due formality in the destruction of an unfortunate cockroach, which had rashly taken a cut across the table, instead of going around it, these gentlemen became indignant and demanded of the Managers to be transferred to the table of the matron. Their refusal to comply with this request determined a unanimous resignation, learing the hospital unprovided with any medical assistance. The erening of that day Dis. Horner and Clymer attended and prescribed for the sick. Here was the cunsus belli, and the Managers promptly passed a resolution of dismissal.

"With the hope of adjusting these difficultics a joint meeting was called for July $2 \mathrm{~d}$, at which Drs. Jackson. IIorner, Clymer, Gillingham, and Pancoast attended, representing as at committee the Medical Board. Dr. Jackson. who seems to have been the advocate in the case, spoke in behalf of the committee, urging the Managers to allow the Residents to remain, at leatst until their places could be properly supplied, and dechining to pass any censure, or interfere in any way in the matter of personal conflict between the Residents and Guardians, as foreign altogether to their legitimate jurisdiction.

"The Guardians, howerer, were inexorable. and refused to recede from their dismissal, thus forever closing the door of compromise. The seceders, after retiring, arailed themselves of the columns of the Ledger newspaper, in which there appeared a card betraying, to say the least of it. a good deal of youthful indiscretion.

"On the same day of this meeting Mr. Flanagan offered the following resolution:- 
-. Resolved, That the Hospital Committee be requested to inquire into the expediency of reorganizing the Medical Department of the house, and report to this Board.'

"On the 21st of July that report was made, which, after going over the ground of the trouble, recommended the abolishment of the Medical Board and the substitution of a chief resident and assistant resident physician, and two consulting physicians and surgeons. On September 15th the report was taken up and passed, modified as follows: "After the first of October, 1845 , there shall be one chief resident physician, at a salary of $\$ 1800$ per annum; one consulting surgeon, one consulting physician, one accoucheur, each at a salary of $\$ 100$ a year.'

"What great results proceed from small and unlikely canses! Who would have thought that the official existence of a medical board composed of the best and ablest men in their various departments on the continent would be suspended on the life of a contemptible cocliroach!

"In this manner the doors of the Philadelphia Hospital, as a school of instruction, were sealed for nine years."

On the 1st of May, 1854, the Philadelphia County Medical Society addressed a commmication to the Board of Guardians of this lospital, asking that its doors be re-opened for medical instruction. This document, although forcibly expressed, produced no change in the views of that body. In August of the same year I)r. John J. Reese, Registrar of the Medical Faculty of Pennsylrania Medical College, communicated with the Board of Ciundians on the same subject, and guaranteed, if its wards were opened to public instruction, the sale of fifty tickets from that school alone.

These appeals had some weight with the Guardians, but, in Dr. Agnew's opinion, it was to Drs. Henry H. Smith, R. A. F. Penrose, and James L. Ludlow that the profession in Philadelphia and the comntry at large were indebted for the re-establishment of the clinical school within the walls of this institution. Dr. Agnew modestly made no mention of his own efforts in 
this direction, for he felt that he was comparatively a stranger in the city, and that he had no influence whatsoever; but other reports gave him equal claim with these three in the success of this opening.

Consequently, on the 6th of September, 1854, the rules for the government of the cliniques were reported, and arrangements were made for the election of two additional surgeons and physicians. On this day the Guardians elected Drs. J. L. Ludlow and Robert Coleman as physicians, and Drs. Inenry H. Smith and D. Hayes Agnew as surgeons. On the 30th of October the staff was increased by the appointment of Dr. R. A. F. Penrose as obstetrician. Tickets of admission were fixed at $\$ 10$, including transportation to the hospital two days in the week- Trednesday and Saturday-for four months. The Westchester Railroad, which passed through the grounds of the institution, was just being completed, and an arrangement was made with the superintendent to run cars from Broad and Market Streets to some point opposite the building, on the days of the clinical lectures. The second week in October, 185t, an immense train left Broad Street, filled to overflowing with medical students, to witness the inanguration of this important erent.

Dr. Agnew has stated that he believed this train to have been the first to have passed over the long trestle-work supporting the road across the meadows of this property. There were at least 700 persons present in the old amphitheatre when the first clinique was held by the new staft. 'The affiars of the Philadelphia Hospital, never particularly tranquil at any time, were rudely disturbed when, in 1856 , clinical instruction was again abolished. In the summer of 1857 , the visiting members of the entire medical organization resigned, several of the resident physicians withdrew, and again the institution ceased to administer to the wants of the medical students of Philadelphia.

In 1858 it was proposed to re-establish the course of clinical lectures, and, on the $22 \mathrm{~d}$ of Norember, 1858, the Guar- 
dians again revived the courses of medical instruction, and elected Drs. Joseph Carson, J. B. Biddle, J. Aitken Meigs, and Samuel Dickson, lecturers on clinical medicine; Drs. John Neill, IV. S. Halsey, Richard J. Levis, and D. Hayes Agnew on clinical surgery; and Drs. R. A. F. Penrose and E. McClellan on obstetrics and discases of women and children. Dr. Dickson's health did not allow him any increase of his labors; so he resigned, and in his place I)r. J. M. Da Costa was elected.

On the the of July, 1859, the old Board of Guardians, which for many years had been elected by popular vote, was abolished, and a new board, consisting of twelve members appointed by the Courts and Councils, came into power. This organization, consisting of the most respectable and intelligent gentlemen in the community, entered upon the work of reform, after a careful survey of the field. As a result of their investigations, they placed the hospital department under the charge of twelve members, consisting of physicians, surgeons, and obstetricians, who were to risit the institution four times a week. The election of these officers took place on the 8th of August, 1859, at which Drs. James 1. Iudlow, William F. Mayburry, Charles P. 'Tutt, and Robert Lucket were elected to constitute the medical staff; Drs. S. W. Gross, Richard J. Levis, Robert Kenderdine, and D. Hayes Agnew, the surgical staff; and Drs. R. A. F. Penrose, John Wilthank, William 1). Stroud, and Louis II Irlow, the obstetrical staff. On the 24th of September, 1860 , the wards of the hospital were again thrown open, this time for free clinical instruction.

The cliniques at the Philadelphia Hospital were held originally in the Insane Department; they were afterward held, commencing in the winter of 1860-61, in a new building built for the purpose. This clinique-room, which was described at the time as elegant and commodious, was anything but convenient and pleasant to either the operator or the students. The accommodations were most cramped and the ventilation was so wretched that, at times, it was almost impossible to stay in the 
room on account of the closeness of the air. This scrious defect has recently been remedied by the erection of a new cliniquebuilding within the present year.

It is interesting to note, in the records of the reports to the Board of Guardians, that during these years Drs. Innew and Kenderdine were the only surgeons who made complete reports of their surgical work. In 1865 Jr. Agnew resigned his position as physician and teacher in this school, Drs. Gross and Kenderdine going off at the same time.

Dr. Agnew established the Pathological Musenm in this hospital and was its first Curator. He retained this position, after giving up his surgical post, until 1867. On Jamuary 1, 1867, he presented a report on the flourishing condition of this museum, while under his care, to the Board of Guardians. This was the last of several letters on this subject addressed by him to this Board. He was sueceeded in this position by Dr. William Pepper. During the fifties this hospital was the only one with which Dr. Agnew was comnected. He received no other hospital appointment until the outbreak of the Civil Wilr.

As a writer, Dr. Agnew was not prolific. Excepting his treatise on surgery, he wrote but very little. Nearty all of lis published articles were written in purstunce of some purpose, such as an address before a society, or to give utterance to his views on some subject important at the moment. 'The tirst book published by I)r. Agnew was prepared to aid his students in their study of anatomy. "Agnew's Anatomy," as it is popmlarly called, or, with its full title, "Practical Anatomy: I New Arrangement of the London I)issector, with Numerous Modifications and Additions," was first issued by J. R. Lippincott \& Co., in August, 1856. Possibly, with the memory of l'rofessor Horner's method of teaching anatomy in lis mind, 1)r. Agnew prepared this concise rolume "with an eye single to the finthful economy of the student's time," believing that a dissector suited to the wants of American students should be much more condensed than those in general use. 
Dr. Agnew modestly called the work "a new arrangement of the "London Dissector," "when, in reality, he changed completely this famous rolume. 'The treatment of the subject was entirely altered and the system of nomenclature changed. This work was not intended to teach the student anatomy, but it was to be taken to the dissecting-table, where it was to be consulted by the student. It was an anatomical libretto. It showed him how to learn anatomy from the cadaver; as such it is a most excellent worli, still used occasionally by students.

This modest little rolume compares farorably with the more claborate publications on the same subject at the present day. The first edition was quite rapidly exhausted, compelling Dr. Annew to publish a second revised edition in 1867, in which he still compressed the matter into as small a compass as powible.

IIis first article published in a medical journal appeared in the Merlinal reml Sreigicul Repoiter, October 15, 1858, in which he made report of a case of ficial neuralgia successfully treated by excision of the inferior maxillary nerve.

It was the custom of the medical joumals of that day to report more fully than is done at present the clinical lectures of the rarious professors, many of the reports of Dr. Agnew's service at the Philadelphia Hospital and at the University of Pennsylrania. where he frequently substituted for Dr. II. H. Smith, then Professor of Surery, being published. The class of cases operated on at this time by 1)r. Agnew were most raried,hernia. lachrymal fistula. cataract, remoral of cancer, etc.,while he included such speeial subjects as the treatment of skim. throat, nose discases, ete.

In the issue of the Merlical and Surgical Reporter for April. 1959. 1)r. Agnew gare his first communication on the suligert of * Regrional Anatomy in its Relations to Medicine and surgery." It was 1)r. Acnew's dream that anatomy should be more closely and practically mited with the work of the practising plussician; and in this scries of articles which he com- 
menced this year, he hoped to show that the subject of anatomy was so important to the ordinary practitioner that a good anatomical education would increase his powers of diagnosis and treatment, not merely in surgical but also in medical discases.

In the next few rolumes of the Medical and Surgical Reporter he continued these papers; so thoroughly dict he go into this subject that, although he frequently published these articles as often as every week for two years, yet, at the end of this time, although he began with the head, he had not finished this division of his topic. The illustrations which he used to illıminate his thoughts were grouped in his clcar, inimitable manner. In 1862-63 the increase of his duties incident to the Civil War broke off his communications on this question, and it was not until 1864 that he was again enabled to publish two papers on this subject; but here, agrain, his duties increased, and he was never able to complete the series. This is a distinct loss to medicine, for it was his intention to republish the series in book form. It was his desire, after he retired permanently from the University, to return to this farorite topic. Ile had in course of preparation, at the time of his death, an article on this subject, for which space had been reserved in the University Mealical Magazine.

The following remarks in relation to this series of articles were published in the North American. Meatical Reproster, a New York journal of the period :-

"The series of illustrated papers of seren of which we have imperfectly indicated the contents, will, if completed, form the hest hody of practical anatomy extant. These paprers wonterfully approach actual work, most perfectly bringing baek to the miml the dimmed impressioms of actual dissection; while of the thearings and practice' there are single paragraphs to be found, so far as we know, in mo printed book in the world, making them worth. to any pratitioner, more than the amount of the year's sulscription to the jumbal containing these practically invaluable communications. Collected in a volume. they form, as far as ther go, a fair setoff in the Euylish langulage to Hyrtl's. Handbuch 'in the German." 
The only other publications from Dr. Agnew's pen during the fifties were the series of anmual valedictory lectures to his classes. published at their request; a pamphlet on "Theatrical Amusements, with some Remarks on the Rev. Henry W. Bellows' Address before the Dramatic Fund Society," in 1857; and an obitnary notice on the late Frederick S. Geiger, M.D., in the Hertiral and Surgiend Reporter, May 14, 1859.

1)r. Agnew's valedictory address to the anatomical class of the Philadelphia school of Anatomy, on February 19, 18.56, affords an opportmnity to estimate intelligently his lnowledge, his beliefs, and his style at this period, and at the same time it expreseses his riews on the duties and privileges of a physician :-

\section{"Gentlemen:}

"This evening we bring our instructions in the lecture-room to a close. In all things I recognize a superintending Providence, by which I have been enabled, amid many and raried engagements, some indeed the saddest of my life, to stand here in my place at each appointed hour to communicate the great lessons of a branch which constitutes the substructure of medicine. In taking a retronpect of the last few montlss, there are many points on which it is pleasint to linger, and among these I ansure you there are none which lindle more kindly associations. and which I rejoice to have this public opportunity to acknowledge. than the mexeptionable decormm, courteons attentim. and mitinge industry of the very large elass who have homored me by their presence.

" In (') loing our winter course of instruction, I cannot allow the present opportmity to pass away without dropping a few cherervations such as the time, the plice. and the occasion suggrest. Dirclaiming all intention to indulge in heartless compliment. I should do great injustice to vou, and violence to $\mathrm{my}$ own frelings. did I refrain to arknowledge in the kindest manner the uniform courtess, grood freling, and attention which have characterized your demeanor toward one who, in an honest 
conscience, has labored to instruct you in a branch which lies at the foundation of a medical education.

"For very many years the department of Anatomy has been taught within these humble walls by many masters of our Art. Some have gone to their reward, others remain as living and successful expounders of their branch, whilst those who have drawn wisdom from their teachings are found oceupying every position, and planted over every portion of our great and happy country. But a very few years ago I entered this room als a teacher, and that single front seat furnished ample accommodations for my andience. Every succeding year has added largely to its numbers, and it now constitutes the largest private class in this country; one which, for intelligence, application, and all the requisites for gentlemanly bearing,-I say it in no spirit of boasting,- -has not its superior in the world.

"There is something of more than ordinary interest and solemnity in the rupture of an intercourse which has grown and strengthened by those affinities and sympathies naturally springing up from the prosecution of subjects of common investigation and interest. A few more days and most of you will have turned your backs upon the scenes which have become limiliar as haunts of study.

"I can picture to my mind the various ferlings which agitate your bosoms. Some filled with the enthusianm of the Doctorate long for the opportunity, like some valiant knight, to test the temper of their armor in the toumament of nodical conflict. Others loug for the renewal of that holy and friendly interehange of feelings which clusters around the sacred circle of home. There is a charm and power about this familiar word which exerts a most mysterious inthence over the human mind.

"Who has not read and wept orer that beantifin and touching description of Xenophon. where the lateked and scarred Greeks, after enduring mutold hardships, and scathed by the fortunes of war, in their homewald return first canglit a glimplese of the broad waters which washed the shores of their native 
land, and rushed into its friendly bosom with the impetuous joy of the pilgrim enthusiant who. coming from the ends of the earth, descries in the distance the banks of his sacred Jordan! The inspiration of this most praiseworthy sentiment cements the heart to forms and principles; it is perpetuating in all its tendencies; it constitutes the bulwark of civil liberty, and under its power a people become terrible in war and influential in peace. It is the paradoxical embodiment of strength in division -lecrmony in disugreement. The idea is happily expressed by Goldsmith, in his 'Traveller':-

"..'The shudlering tenant of the frigid zone

boldly proclaims that happiest spot his home;

Extols the treasures of his stormy seas,

And his long nights of revely and ease.

'The maked neolo, panting at the Line,

Boasts of his golden sauds and palmy wine.

Such is the patriot's boast where er we roam,

His first best combtry ever is at home.'

- Ton have, gentlemen, adopted the profession of medicine as the pursuit of your life, and I doubt not it is your desire to malke the resources of that prolession tributary to your name, your wealth. and the happiness of your race.

- I am aware it is cuntomary to exalt the disinterestedness of medicine, so as to exchude all considerations of self; to libel merme as vanity, and gold as contemptible dross; but I have no ohjection to that soltishness which would rather provide for one's own lomse than be stremed a heathen man." And even were it true cither in principle or fart. the public are not prone to sin rergerierously against your dignity or conscientious delicary. If. however, you enter upon the duties of your calling cutertaining such pucrile fancies, your mind will soon become disibmed. And why not? Are we not made of the same stuff as other men? We cammot live as a plant. upon the air ; nor can we subsist upon the bonisons of grateful convalescents.

11 Timotly, 5tlı chapter, sth verse. 
"May we not exclaim with the Jew in the "Merchant of Venice'-Hath not a Doctor eyes? Hath not he hands, organs and dimensions, affections, passions, as others have? If you prick us, do we not bleed? If you tickle us, do we not langh, feed with the same food, and hurt with the same weapons? It so happens that the Great Creator most generally comnects our duties with our interests; so that, the more ardently we prosecute our partialities, the more do we contribute to the general good of the human family.

"In medicine, as in every other occupation, the first step is the most important. For its successful prosecution, qualifications of no ordinary character are required; and to have a full comprehension of these is a very essential step toward success. You all aspire to distinction in life. It is a noble sentiment, and yet there is none so commonly doomed to disappointment. Who can tell how many professional hopes have vanished like dew before the morning sum? How many brilliant anticipations disappointed, and noble plans miscarried? Why is this the case? Certainly not from a defect of talent.

"Not one of the liberal professions comprise so large a share of talent as our own. It brings into its ranks, in point of ceducation and manly endowments, every qualification essential to the accomplishment of any reasonable result. For the explanation we must look, therefore, not to the want of talcut, but its misapplication, and a little investigation will revall the true cause. Let us examine some of these for a short time.

"Many are prone to consiler that, as soon as they are released from their collegiate minority, labor is at an end and their education completed. They carry with them the views of instructors, adopting these as axioms in science and undeviating rules for their future practice. It is all well to rewarel with the highest consideration these tearhings. The idea that they are not worthy of your confidence and application is not for a moment entertained; but it is that sorvility of conduct. that forfeiture of independent thought, which is to be teplored and 
condemued; for it is the sure precursor of a routinist, who is crer content to follow, never aspires to lead. It should be the first ereat duty of one just initiated into the brotherhood of medicine to tent the truth and ralidity of the basis upon which his education has been erected. Our science courts investigation-nay. challenges examination. It is not to be supposed that the multitude of opinions gathered into the literature of medicine would lail to create doubts upon some points. These are questions for your own solution, and the exercise of a doubt involves no in. Indeed, there can be no progress without it. It has ever, and will ever, be the great pioneer in all redorms.

. In fact, conformity of sentiment camnot be expected. Men, from their very organization, examine subjects from different points and in different modes, and the varions accumulations of facts which are thus gannered into the great depository of the sience become the property of some future medical philosopher, who tashions ont of them some general law, whose every part beams with the liamony and light of proportion and truth. Lniveral conformity in any department, even were it possible, woukd he fital to progress. What a fool have I been, exalamed chartes $\mathrm{V}$, when, to relieve the tedium of his kingly wile. he ammod himself in attempting to regulate a few Watelues to a common time. What a fool have I been in 'mlatroring to compel living men to think alike, when I cannot malie two dumb watehes keep time together!'

. It - hould be remembered that, in espousing the profession. you incul solemm moral obligations which may not be lightly shaken off. It is no trivial consideration to assume the manawenent of the health and lives of a community. You have seren enough in your anatomical pursuits to teach you that to compredend the workinges of so complex and curiously-constructed a sytem as that of man is a task of 110 mean magnitucle, and to fithom the has by which its mysterious processes are conducted requires all the concentration of mind, acute- 
ness of observation, and philosophical disposition of fucts you can command. The expounder of your art can hope to do no more than to inculcate principles which are mirersal and general in their character. The applications of these to special conditions must depend for success upon the logical correctuess of conclusions formed by rigid analysis.

"Inordinute expectution from the resources of the profession is another source of difficulty. The public are exacting in their demands and expect you to accomplish very many unreasonable results. Toltaire's definition of a Physician expresses the idca: "An unfortmate gentleman who is expected to perform a miracle every day in reconciling health with intemperance.'

"The student enters upon duty as though he had little else to do than to level with a stroke every enemy of human life. Failing to accomplish all his sangume confidence would desire, he loses faith in its potency for good and pursues it as a trade rather than a science. A moment's consideration will correct all such unreasonable impressions. The system is i kind of federal compact, an assemblage of mumerous distinct independencies. There are laws belonging to the individual organs, and so are there laws regulative of the combined operitions of its parts, and, as each indivilual part is comsidered sorereign, one does not entrench upon the other; and as the general laws grow out of the combined neecesities of individunl portions, their influence must be in a great measme conscrvative.

"Interruptions of these laws constitute disase; and when the quiet and normal exercise of the legitimate finctions of an organ have been assailed by some cnemy who secretly gains access to the citadel, see how promptly all the other portions resent the injury and combine to eject the intruder! sec how the skin mantles with generous indignation and sweats with arduous toil! Iow the heart thumps like an imprisoned giant against the bars of his cell and lashes the crimson torrent along the shores of the systemic rivers, as if to wash out the very 
foot-prints of the invader! The lungs breathe a tempest. The glinds, for the most part, shut up their bosom and refuse supplies; the eyes melt with pity and shed tears of sympathy. The little chsorbent traders, who visit all the avenues of the body in scarch of wares, refuse to replenish at the great marts of commerce; all work is suspended until safety and peace is restored.

. What a lesson to a people, citizens of a country of different agrgregated interests like our own! May the same principles of fraternity bind crery member to the great centre of our national Lnion, and may its enemies, whether at home or abroad, meet with the same unterrified rebuke! Now, the tendency of deranged organic actions is generally sanitary, and, in a large proportion of cases, adequate to accomplish their own relief. It is only, therefore, when these processes are likely to fail that medicine legitimately interferes. The judgment and address of the Phrisician consist not in the administration of remerlies, but in knowing when to administer; not only in employing weapons, but uhen to employ them. Habitual inattention to these considerations will defeat the best intentions of the profession, and. under the hue and cry of an unsuccessful Luctor, he too often beats an inglorious retreat into some of the innumerable sinks of quackery. Another prolific source of failure is the wide-spread idea that some lucky chance or accidentul youl future will elevate suddenly to position, as the breaker atches upon its bosom the bubble of surf and drops it high upon the sea-beach. How unlike our conduct in the common affairs of lite! Would you linger at the risk of starvation "1pon some barren island of the sea in full view of land, with all the materials to construct a raft in profusion around, in the hope that, perchance, the friendly winds would bring some propitions sail?

- Look into the world of matter. Do the small particles which in the aggregate construet the glittering crystal take their definitive posts at hazard? Do the elements which the chemist brings into relation settle into place by accident, and form for- 
tuitously the various compounds? Do those brilliant orbs which sparkle in the rault of heaven move through the highwars of space, impelled by chance? There is no such thing. All are acting under laws emanating firom the throne, as unalterable and fixed as the God who sits upon it, whose operations are seen as well in the mote which floats in the sumbeam as the mightiest planet which wheels in his orbit; as manifest in the tint of an insect's wing, the creature of a day, as in the rainbow arch which spans the skiy.

"Others toil in search of specific agents wherewith to medicate. They are like those ancient philosophers who spent their lives in the fruitless attempt to discover that magic stone which was to turn all the baser metals into gold. Or those Castilian adventurers who, led by the Cavalier Ferdinand de Soto, wandered over our continent in quest of precious mines, or some potent spring, whose recuperative waters should stay the march of years and clothe the body with the bloom of perpetual youth. 'Leave that to the winds,' said the impetnous Alarie, in answer to his pilot whither should they tum their prow,- - Leave that to the winds; they will be sure to waft us to the desired coast.' 'There can be no greater mistake, gentlemen, than to suppose the instrumentalities which lead to success in other vocations of life will be suspended in favor of you. 'There must be a diligent and patient employment of means, if you expect desired ends; you must invoke causes if you hope for consequences. It was not fortune which filled the world with the name of Nilpoleon. All his great successes and master-strokes, as they were wont to be termed, were nothing more than the excention of plans rigidly constructed in the mind of the First Consul, both for ordinary and extraordinary circumstances.

"It was not chance which made a great constitutional lawyer of Daniel Webster. Nor was it chance which made a Phỵsick or a Rush the ornaments of your orn profession.

"Promotion is a plant of slow growth. The road which leads to distinction is rough and rugged, and many pilgrims grow faint 
and sink by the way. The grain does not ripen to the perfect harvest by gentle gales and unbroken smohine; it must have the storms, the winds, and the frosts of heaven. Narigators tell us, and our own intrepid countryman and professional brother, Kane, whom the world delights to honor, has verified its truth, that around the pole flows a sea of open water; to reach it, however, the mariner must encounter icebergs and storms. Just so it is with the goal of scientific distinction. It is an inviting spot of rale and dazzling beauty, but to reach it there are many Mont Blancs to scalle.

"Still, let your peculiar difficulties be what they may, history has placed on record examples for encouragement. Is your time distracted with onerous cares? Be it so! Cresar wrote his Commentaries and governed a kingdom. Does porerty pinch with its Shylock grip? Poverty produced the immortal poet Dante, the - Iliad' of IIomer. the 'Maxims' of Terrence; and the owner of hut four acres of land, by the unanimous acclamation of the Semate, became the Dictator of Rome. There is a power, a moral sublimity in undismayed persererance and virtue, which, planting its shoulder resolutely against the wheel of life, and not idly supplicating the aid of Jupiter, forces and compels the world to resperet and homage.

" 'The unfortmate anthor of - Lacon' has said that many men fail in life from the want, ats they suppose, of those great oceasions wherein they might have shown their trustworthiness. But all such persous should remember that before we place wine in a rescel we try its integrity with water ; and it is attention to what are frequently termed the trivial duties of a profession which pares the way tor higher adrancements. This landing at a single bound from the cradle into mature manhood is one of the remalkable characteristics of the age. In the high-crown hat.. Shanghai coats. and air of' monchulenee, we fail to recognize auy longer the boy. Scarcely are many loosed from the leadingstrings of the schools. when they appear as the expositors and oracles of scicnce. We would not assert that early genius 
may not render important contributions to our branch. Dante was an author at a very early age; schiller wrote an epic before he had attained his fifteenth year; Tasso was a prodigy at five; and Mozart astonished his fiends at three years of age with wonderful executions which foreshadowed his future trimphs. Tisconti knew his alphabet at eighteen months, and ere he had attained his fourth year read fluently the ancient ransics. Years have rolled away, and their productions still stand as the models of our literature, gathering additional strength and brilliancy with age. What think you will be the judgment of opinion two generations hence upon much of our early authorship?

"Time is the great adjudicator ; it will preserve and burnish the gold, and it will bury the dross. When the immortal Kepler discorered the laws which harmonize the morements of the hearenly bodies, he is said to have exclaimed " Whether my discoreries will be read by posterity or by my contemporaries is a matter that concerns them more than me. I can wait a century for a reader, when God has waited some thousands of years for an observer like myself.' Tre thiuk many care little about the decisions of the future if they can secure the approval of the present.

"But I fear I have wearied yom patience, and, though I would feign linger among you. I hasten to conclude. Nany of you are about to enter the lists and masure arms with the multiplied enemies of our race. Talie care-take are that your armor befits you. The stripling shepherd of Istael in vain essayed to meet the giant of Gath in the cumbrous panoply of Saul; and it will be better with you. as with him. to venture with the simple staff and sling of mupretense.

"There is everything in preparation. I take it. no man living, who has carefully watched the chift of life. but will have marked certain periods when he might have embarked in business with every prospect of sucess. 'These may be termed seasons of opportunity. They pass along some time or other 
by every man's door. The great secret, gentlemen, is to be fully equipped, and seize the moment when it comes.

... We must take the current when it serves,

Or lose our venture.'

"Wherever, in the will of Providence, your lot may be cast, you have my warmest wishes for your personal and professional happiness and success."

'This address was written by Dr. Agnew in one evening; it stands exactly as it was prepared, without corrections or additions.

At this period a coincidence showing the unity of mind of the Agnews upon religious subjects occurred:-

"A Manmal on the Christian Sabbath," written by Rev. John IIolmes Agnew, D.I)., was published by the Presbyterian Board of Publication in Philadelphia, in 1852. In this work, this learned professor studied the institution, perpetual obligation, change of day, utility and duties of the Sabbath. He also waged warfine on all Sabbath-breakers in most valiant style. Curiously enough, in the Appendix are abstracts from the report of a committee of the British House of Commons on the observances of the Sabbath, of which another member of the family, Sir Andrew Agnew, was chairman. In this report the cudgels are talien up in fivor of the Scottish Sabbath, and, among other things, the description given by Sir Walter Scott of the Sundiy of the Covenanters is disputed.

In the latter part of the fifties, Dr. Agnew was honored he election to membership in the Board of Managers of the Ilonse of Riefuge, the appointment being made by the Judges of the C'ourts of the City of Philadelphia. Ile joined, also, in thene rears, the Philadelphia Comty Medical Society and the College of l'hỵicians.

Keen eyes in the city were fixed upon him; men of skill and cminence were talling about him. Signs of his strength had aronsed attention. Smith and Jackson, then foremost in 
their profession, had tested the stranger, and they found what, in after years, we have all come to know-that Agnew never failed when he was tried. So the doors began to open; the doctor and surgeon began to be known; the path grew easicr; he drew longer breaths, and felt that the battle was now in his own hands, under that merciful Providence whom he had erer trusted, and now trusted more than ever; but those stern years never left his memory In speaking of these days, he has said, frequently, "The time a man needs God the most is when he feels that he deserves success and doesn't get it."

Work had not ceased with him, but it had changed its character; it was not now a struggle for sustenance, but unconsciously for supremacy. 


\section{CHAPTER VI.}

\section{DR. AGNew's Life Fron 1860 to 1870.}

Like other Americans, Dr. Agnew's quiet, tranquil life was rudely disturbed in 1860 by the commencement of the terrific struggle of the Southern States to separate themselves from the Union. The part borne by Dr. Agnew in this conflict was no small one. A surgeon's position in war-time is always most important ; but for his skill and work the horrors of war, already terrible, would be increased a thousand-fold.

1)r. Agnew, in common with many other clear-headed men before the commencement of the war, such as Abraham Lincoln, while in firvor of the abolition of slavery, was opposed to the methods by which the Abolitionists proposed to bring about the accomplishment of this purpose. He believed thoroughly in the extinction of slavery, and had studied the problem for many years.

It seemed to him that the removal of slaves to the country from which they had originally come, in a climate to which their constitutions adipted them, with the addition of all the agencies of civilization to which they had grown accustomed, was the proper solution of the rexed slavery question. He was well chough arquainted with the temper of the South to know that the 1 bolition morement in itself tended inevitably toward war, and possibly, toward dissolution of the country. On this acrount. years before, he had become an active member of the American Colonization society. Ile had hoped that, in the fomelation of the Iiberian Colony, the solution of this terrible question would be found; but as the country was swept along irresistibly to the terrible vortex of a civil war, the subject of slavery and the threatened dissolution of the government were forced upon his attention. in the most practical manner, before the outside world had felt the rigors of war,-when he (128) 
lost, in a night, the majority of his Southern students. At this time this action, together with the request of a jortion of his class to hurry the course of instruction, led him to speak on the all-absorbing question of the abolition of shrery. The temperate tone in which he discussed this burning question shows that he had taken up its study with his characteristic calmness. He spoke as follows:-

"When I east a glance over these seats, I discover many faces absent which hatd grown fimiliar from the regularity of their presence. This circumstance and also a reguest from a portion of the elass constrain me to notice one of the most extrandinary incidents, - one without a precerlent in the history of this country, - that of a large mumber of edneated young men, prosecuting their professional studies, suddenly abandoning the institutions of one section for those of another.

"The question naturally presents itself,_What ciremmstances hare eaused this remarkable action? IIare the schools of Philadelphia, so long famons for their derotion to medieal education, hecome degencrate plants of a noble vine? Have those, their functionaries, who now stand forth as the expositors of onr art, lost their power to eharm,-their voices become mute, and their emuning departed? Hats the Philadelphia Hospital, - with a population of over three thomsand souls.- the P'em-ylvania Hospital, The Wills, and other eleomos!nary institutions mo sick, no hat, no blind upon which to demonstrate the partical power of medicine, and introdnce the student into the beneficent functions of his profession? Have the resonrees so necessaly to smitain a borly of zealons young men during the period of pupilage sudhenly hecome iried upl? 1las some modern development cle the the great looly of medicine in twain, an

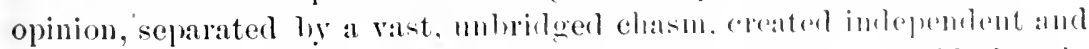

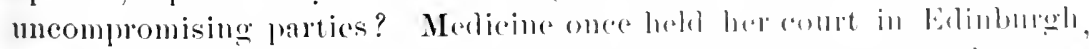

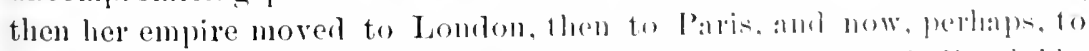
Vienna; ret the science was one, and still so continues imbiscolulle,

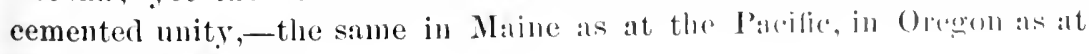
the Gulf of Mexico.

"Not one of these catastrophes has halppened. Then. to what

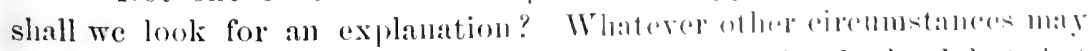

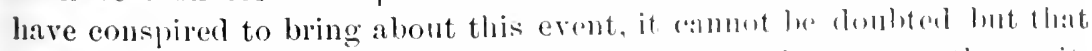
the agitation of the long-rexed (fnestion of negro stavery was the exciting cause. Long confined to the arena of polities, this sulpject hats. from various influenees, been rising in matnitume, nntil it has assmued an

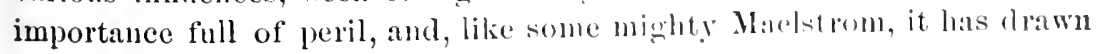


into its revolving eurents all oc(oupations, trates, and professions. A suljeet, therefore, which las become so disturbing an element to the peace of the States; which has rent asunder large hodies of denomina. tional Christians; which arows, with unblushing insolence, the most horrible doctrines, inciting to riot, rapine, and murder, and openly counselling and practicing resistance to the supreme anthority of the land; and which even threatens the proscription of our very seats of learning on accomt of theil geographical relation to a particular line, may well elallenge our most earnest attention."

Continuing in this strain, Dr. Agnew made a stirring address, in which he reviewed the past history of the country, and ured the love of patriotism and forbearance upon his students. Ilo believed that the dissolution of the country would be most calimitous. He believed that it would settle none of the questions at stake; that it would doom the slave population to the most rigorous and most hopeless servitude, and possibly to entire extermination. He believed that the line of separation, if drawn. would be crimson with the blood of border warfare. He felt that it would be better to have war, pestilence, and famine a thousand times together than that such a catastrophe should oecur. In conchnding this stirring address, he hoped that all his students would carry with them, to whatever spot they went. love and honor for their comtry and the memory of his admonitions.

II published, during the winter of 1860-61, his lecture on the ". Career of Baron Larrey," the great surgeon of the Napoleonic wars, in order to present the life-work of one who stood pre-cunincut among military surecons, — whose example may sere as a model for the ambition of my professional countrymen at a period when events portend a struggle of no ordinary mannitulle."

When war was eventually declared, Dr. Agnew thew all the resoures of his training into the service of the government. from the position of his shool.-near the seat of war,-it attracted, naturally. humdreds of students who were anxious to complete their cducation to such a degree that they could serve 
as assistant surgeons in the army. The line of teaching which he had been following on anatomy and surgery was exactly suited to the requirements which they wore expected to meet as army-surgeons. In consequence, comntless surgeons went to the war prepared, through the teachings and demonstrations of Dr. Agnew, to aid their countrymen, to alleviate their sufferings, and to ward off disease and death.

On June 11, 1862, he entered into contract with the government for service as Acting Assistant Surgeon in the United States Army, on duty at Satterlee General Hospital, in West Philadelphia. On July 17, 1862, he was transferred to duty at the Hestonville General Hospital. On October 26, 1862, his contract terminated, he being appointed Surgeon of Volunteers. to date from October 6,1862 . He continued on duty at this hospital, as Surgeon-in-Charge, until April 7, 1S63, when his resignation was accepted, as his professional services as lecturer on anatomy and operative surgery dicl not permit of his transfer to duty elsewhere. From December, 1862, to January, 1863, he was also a member of the Medical Examining Board for Volunteer Surgeons. On Augnst 11, 1863, he again entered into contract for service as Acting Assistant Surgeon, being assigned again to duty at Satterlee General IIospital, in West Philadelphia. 'This contract was terminated October $7,1863$. On May 12, 1864, he entered into contract for service as Consulting Surgeon, on duty at the Mower Gencral ILospital, Chestnut Hill, Philadelphia, where he remained on duty for nearly fourteen months, - until July 8, 1865,-when his contract was terminated.

As can be seen from this official report of 1)r. Agnew's service during the Civil War, his first comnection with a military hospital was with the Satterlee General 1lospital; but he was transferred, after a month of service, to the ILestonville General Hospital, where he was Surgeon-in-Charge.

The United States Military IIospital at IIestonville was opened in July, 1862, with Dr. Agnew as Surgeon-in-Charge, 
and with Dr. John W. Lodge as Assistant Surgeon and Executive Officer. 'The large room over the dépot of the lace and Vine Strects Passenger Railway Company was utilized for this purpose, containing two hundred beds. The place was not well adapted for hospital purposes at first, but later the room was divided and the varions offices attached. Under the direction of the Surgeon-in-Charge it soon became one of the best in the city. It was here that Dr. Agnew had his first experience with military surgery and the management of gunshot wounds. He bestowed the greatest (are on all his cases; his interest in their condition and welfure was absorbing. This was a new field for Anerican surgeons; it was their first experience with the injuries, accidents, and diseases incident to military operations in the field, since the introduction of anesthesia and the improvement in modern war-implements. Dr. Agnew, among many others, studied his cases with care and spent many hours each day in the wards.

At this time Dr. Agnew's great kindness of heart and simplicity of character showed themselves most strongly. Among the wounded were many Confederate soldiers, far from home, among a people something more than strangers, and ntterly penniless. To these he was especially tender, and aided many materially from his own then limited means.

The IIestonville Hospital was closed in April, 1863, having been open nearly a year, Dr. Agnew contimumg in charge until its close. Without previous experience Dr. Agnew managed the hospital. from the boginning to the end, without complaint from the government. Much of the routine of the govermment was complicated at the begimning of the wall, and many of the hospitils had much trouble in their settements; but there never was " quention as to the disposition of the property intrusted to him. The tronble was usually due to inexperience in the preparation of papers; 1)r. Agnew's papers were always correct.

It was not at Mower Hospital. as is generally supposed, but at II 'stonville, that Dr. Agnew had his first great opportunity 


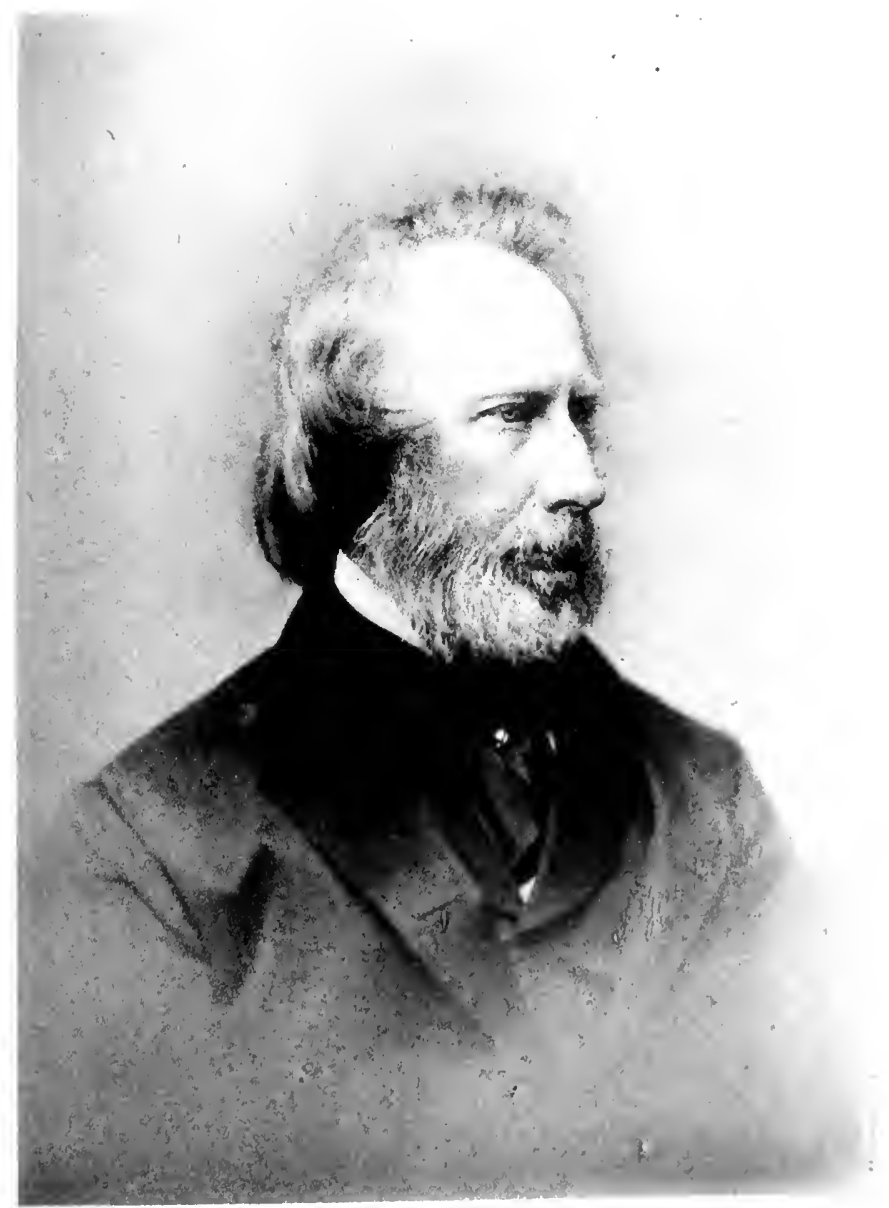

Dh. AGNEW IN 1867 . 
of studying gunshot injuries; here he had ample time and ample material. His studious life, his previous experience as a surgeon, and his natural aptitude fully equipped lim to deal with every emergency.

On the closing of the Hestonville General Hospital, Dr. Agnew was too busily engaged at the School of Anatomy to be transfered elsewhere; but in the fall he returned to service, being assigned to duty at the Satterlee General IIospital, where he remained several months.

The Satterlee General Hospital was located at Forty-fourth and Pine Streets, in West Philadelphia. It had twenty-cight wards, with a capacity for 70 patients in each, making a total capacity of nearly 2000 patients. The erection of this hospital was due to the liberality of the merehants of l'hiladelphia. Dr. Isaac Hayes, the celebrated Arctic explorer, was the Superintendent.

After the Battle of Gettysurg Dr. Agnew went to the battle-field, and performed efficient service in the hospitals there. Among other patients, he had charge of the case of General Winficld S. Hancock, who was severely wounded during the battle. When General Hancock was andidate for the Presidency, twenty years later, it male a strange coincidence, for, as a result, Dr. Agnew had charge, in his life-time, of the cases of both candidates for President of the United states in 1880 ; both being under his care for the same lind of injury,guushot wound.

The most important commission held by 1)r. Agnew during the war was at the Mower Gencral IIospital, at C'hestnut liill, Philadelphia. His commission here was dated May 12. 1864. This was followed by the appointment of J)r. 'Thomas G. Morton to a similar position, June 2,5, 1864.

The Mower General Ilospital. located by the government at Chestmut Hill, Philadelphia, was built in the form of a thattened ellipsoid, the length of its main corridol being one-half mile. An idea of its size and capacity can be gained from the 
fuct that twenty-seven acres were inclosed within its walls, and the cirrumference of its grounds was just one mile. The ward buildings ran off from the main corrictor like the spokes of a wheel. It had a capalcity for 3600 people, 3100 of these being patients and 500 attendants and guards. Its position was most fortunate; it was located in a most healthful position, on an clevated plateau, four hundred feet above tide-water.

It was arranged that each consulting surgeon went out to the hospital on alternate days, Sunday being omitted except in cases of emergency, when they were sent for. There were fortyeight wards, in each of which was stationed an assistant surgeon. 'Twenty-four wards were assigned to Dr. Agnew and the same number to $1 \mathrm{M}_{1}$. Morton. It was the custom of the surgeons to reach the hospital at 1 o'clock and remain all the aftermoon, first going through cach ward with the ward-surgeon, then examining all cases for operation. These were then conveyed to the very commodions operating-room.

Only the minor operations were performed by the resident sureons. Emergency operations which could not wait for the consulting sureons were performed by Dr. Moon, the first assistant under 1)r. Iopkinson, the Superintendent.

Although the hospital had been built to accommodate only 3100 patients. yet it was frequently so crowded that over b)(o) (ates were at one time within its walls. The possibilities of the service can be estimated when it is seen that this number wonk mike a good-sized town, cach inhabitant representing an important injury, no two of which were exactly alike. Each (alse was a problem in itself, and the task of caring for them was a terrific molertaking.

The operations performed were frequently of the greatest mannitude, such as ligations of the principal vessels, as the (o)mmon carotid, the femorals, otc.; amputations of all sorts, resections. trephinings; extractions of balls and missiles generally. It was no uncommon occurrence that a number of these major operations would be performed on the same afternoon. 
The geographical relation of Philadelphia to the various points of conflict made it one of the most conrenient points to which to send the wounded soldiers. In consequence, the Pliladelphia surgeons of the period acquired reputation and experience which served to strengthen their position as being the most brilliant and successful operators in America.

When the war was ended, in 1865, Dr. Agnew's contract was terminated and he returned once more to the quicter rontine of his regular professional work.

It was by this extensive experience during the war that Dr. Agnew acquired his reputation as the great authority in America on gunshot wounds, which led to his selection as c'onsulting surgeon in the Garfield case.

The other members of the Annew family were not idle during the period of the Civil War. Professor John Holmes Agnew published, in conjunction with J. S. Wright, a most elaborate article on the subject of the Federal Union, entitled "Citizenship Sovereignty." In this work, reply was made to the arguments brought forward that the gorernment had no right, by the power of the Constitution, to prevent the Southern States from seceding, and that slavery wals a dirine institution. The amount of work expended on this little volume must have been tremendous. Professor Ignew supplied quotations from Biblical authorities, Grotins, P'ufendorf' Yattel. Montesquicu, The Federelist, Madison's Debates. Curtis's - Itistory of the Constitution," ete., in oreler to strengethen and verify the statements made. This work was published in 1863.

At the same time the IIom. 1)aniel Lonew, at that period President Judge of the Serentecuth Judicial District of P'ennsylvania, delivered an address on "Onr Xitional ('onstitution: its Adaptation to a state of "War or ln-mrection." In this essay he presented clear views of the change wrought by watr upon this frame-work of our mational life. and the dormant energies it starts into activity. In this angment he proved that the Constitution was legally conabled to act in such an 
emergency as arose at the beximning of the late Ciril War. In doguent and patriotic terms. he proved logically and fully that the goremunent had the right to lery war when the necessity arone.

1)uring the (ivil War I) Ignew finally severed his connection with the Sichool of Anatomy and received his first appointment at the Lnirersity of Pennsyluania. For some time combiderable hostility had heen shom to the School of Anatomy by the two medical schools of Philadelphia on accome of its trementous a and reputation. 'They folt. maturally, that their position was being unped. By this more the breach was laiplpily saled.

The (arliant connection of I)r. Annew with the University of Poumstrandia an a teacher was mofficial, dating back as far as 1 S.j. Whens. at the solicitation of I)r. Henry H. Smith, then Profe-wor of turerer. 1)r. Agnew subtituted for him at his clininges. in the conrse of resular clinical instruction. He continued this relation with I)r. Smith, frequently acting as his substitute in the instruction of the students. until December 21, 1863, when he received his first official appointment to the Luiversity, being male Demonstrator of Anatomy and Assistant Lecturer on C'linieal suruery. 'This latter title was not accorded him, howners. in the antalognes of the perionl. He succeeded Dr. Willian IInut a - Demonstrator of - Inatomy.

'lih was a fortunate move on the part of the Luiversity; fur she ubained a lecturer who had proved himself the best and mont sucerenfinl teachere of the period, who would also tend to attracet to her lecture-halls many of the students from other schowh. who had beene studying under Dr. Agnew's eare at the sibuen of Inatomy. This is a potent influcnce in medical instmetion, "hich "an be seen in any medical school; one miln's reputation can have much to do in attracting medical students. Modical students are very much given to the worship of some idral teateher or operator. and frequently go long distances simply to shud! moler a certain professor. Being, as 
a class, much older than ordinary collogiate students, and more independent as to their morements, they are able to do this.

An example of this tendeney is seen in the autobiography of that eminent surgeon, Dr. Sammel 1). Gross. Ho stated, in this history of his life, that he left his preceptor in Liaton to enter the Medical Department of the University of P'mustvania, having in his pocket letters of introduction to sereral of the professors; but, visiting the clinique of 1)r. (ieorge MaClellan, who was then Professor of Surgery at the recently estal)lished Jefferson Medical College, he became so fiascinated with the personality of this distinguished surgeon that he gave up at once all thought of going to the University.

The number of students who were attracted to the University by Dr. Agnew's reputation can never be estimated, of course; but, undoubtedly, Dr. Agnew added as much to her financial condition as he did to her moral and scientific side.

Dr. Agnew, on the other hand, obtained. in his demonstratorship and lectmership, a fair position in the Lniversity, lut not one at all commensurate with his reputation and talents. He was not made a member of the Faculty, although his position, of course, was one which was directly in the line of promotion. The appointment to the position of l)emomatrator of Anatomy at the University of Pemeylvania rests in the hands of the Prolessor of Anatomy; consequently. 1)r. Lenew owed this position to the courtesy of I)r. I ceily. As Ansistant laceturee on Clinical Surgery, he was requested to assint the Profensor of Surgery in the conduct of the sureicali diniques.

The composition of the medical faculty at this time was as follows :-

\section{Emerilus Professors.}

Wilitian Gibsox, Professor of Surgery.

George B. Wood, Professor of the Practice of Medicine.

Sanuel Jackson, Professor of the Institutes of Medicine.

Hugir L. Hodge, Professor of Olstetrics aud Diseases of Women and Children. 
IPediral Fuculty of the Cniversity of Pennsylvania in 1863. Josern Caksos, Professor of Materia Medica and Pharmacy.

li. E. lirgers, Professor of Chemistry.

Ju-EIII LEHT, Profeesor of Anatomy.

IIExry 1I. SnIth, Professor of Surgery.

Willian Pepper, Prolessor of the Theory and Practice of Medicine.

Fraxcis Gruner surti, Professor of the Institutes of Iledicine.

Richini, Alexaxder F. Pexhose, Professor of Obstetries and Diseases of Women and Children.

On the appointment of Dr. Agnew as Demonstrator of Anatomy there was the commencement of the extension of clinical teaching at the University again. Just as before his admission as a student in 1836 there had been an impetus given to clinical teaching, so again on his admission as teacher at the University a similar impetus was imparted. He gave, during the winter montlic a course of lectures on "Regional Anatomy," and a comrse on " Operative Surgery" in the spring. In the years 1865 and 1866 he gave summer instruction for students at the University, the course consisting of a series of lectures on "Operative surery and Anatomy." These lectures ram through the spring and summer season, beginning in March.

For the next scron years Dr. Agnew served faithfully the Eniversity in the position of Demonstrator of Anatomy. As the rairs rolled by he grew to be more valuable as an acquisition to the teaching corps of the University, and his general reputation adranced rapidly. I Ie lectured in the evening, twice a $w$ ock. from 7.30 to 8.30 . spending the remainder of the evening in the disceting-room; but he was there frequently also on other creminges. The duties of his position were the same as thwe which he had administered when in charge of the School of Anatomy. Ile experienced, throngh all this period, a great lirk of suplely of anatomical material; the Minutes of the Finculty mecting of this time contain several pleas from him, ureing upon the Faculty the importance of their taking active mointues to make alrangements by which the supply would be made more certain and more regular.

After seven years of hard service, finally, in 1870, Dr. 
Agnew intimated his intention of resinning his position as Demonstrator of Anatomy in the Medical Department of the University. This intention on the part of Jr. Agnew was deemed of sufficient importance for the calling of a Faculty meeting. As a result of the conference at this meeting. at a stated meeting of the Board of 'Trustees held Marrh 1. 1870, Dr. Agnew was nominated for the Chair of Clinical Surery; at the stated meeting held April 5, 1850, Dr. Agnew was elected to this chair, the title being changed to that of " Professor of Clinical and Demonstrative surgery." the term "demonstrative" being added in order that he might be cmpowered to carry out fuller instruction in demonstrative sulgery. This chair had been moecupied since it had been valated by Professor Norris, in 1857.

At the request of the Faculty. the Trustees had revived this Chair of Clinical Surgery, which had formerly been held by the late Dr. George W. Norris, confering it upon 1)r. Agnew, who thus became a member of the Faculty of IIedieine in the University of l'ennsylvania at the ane of 52. and alter practising medicine for thirty-one years. The student who expects to be a professor a year or so after graduation can find here a good lesson in patience.

Dr. Agnew, in being made Profesior of ('linical and Demonstrative Surgery, was put more nuon an equility with his fellow-teachers. There is 110 reason why he shombl not have been given this position on his first conneretion with the Lniversity, excepting the fact that he was perferety contented with the demonstratorship); his own ambition being satisfied. there was no one to suggest his further adrancement to the profestorship in the clinical chair. He was not foreing Dr. Sulth, the Professor of Surgery, from his lawfin position; on the contrary, he was aiding that chair and lightening its duties.

The history of clinical instruction at the University is so comected with the history of this chair that it is briefly quoted. In $18+1$ the system of dispensary cliniques was 
adopted by the Cniversity; the first that was instituted under its anypices was couducted by I)rs. Gerhard and William P. Jolnnton, in the building of the Medical Institute, in Locust street above Elerentl. It was there carried on until the commencement of the course of 1843 , when it was transferred to the Lniversity building under the immediate supervision of the professors. with the assistance of these gentlemen. From that time to the present, this mode of practical instruction has constituted a part of the regular course of medical teaching conducted by the Lniversity.

In comnection with the clinical service, two rooms within the building were appropriated for the accommodation of patients requiring operations who could not be immediately removed. By this arrangement, the same attention, nursing, and care was bestowed upon the subjects of cappital operations as in a hospital.

With a view of completing the plan for clinical instruction so as to give it the greatest efficiency compatible with the progress of medical colucation, it was resolved in 1845 , by the Faculty, that a sureon connected with the Pennsylvania Hospital, and whose duties there were performed during the session of the Lniversity. be requested to officiate as clinical lecturer on surerery. This led to the creation of a Chair of Clinical Surgery in the Cuiversity, by the Truntees, and the appointment by the Boald, in 1st of this office in the hospital. In 1848 Dr. Randolph died, and

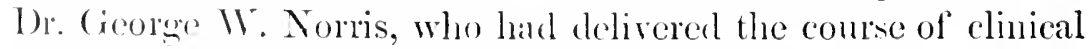
lectures meler the anspices of the University during Dr. Randolphis illuens. War cleceted his successor in the professorship. 1)!. Norris antinued to perform his duties as Clinical Professor until 14is. when, upon being elected a Trustec of the Unirersity. he resigned.

1)1. Lonew was suceeded by D). H. Lenox Hodge as Demonstrator of Anatomy. 'There was still great growth in the clinical department, clinical lectures being delivered daily throughont the ycar. 
In the following year Professor Henry II. Smith, not heing in sympathy with the expansion of clinical teaching, resigned the Chair of Surgery, and Dr. Agnew was chosen his successor, the surgical teaching of the University heing thus again united in a single person. The chair which had been revived to serve as a medium for admission of 10r. Agnew to the Faculty was abolished. On the establishment of the University Mospital, in 1873-74, Dr. Agnew was made Professor of Clinical surgery, still retaining, however, his didactic chair, and the late Dr. John Neill was associated with him also as Professor of Clinical Surgery. The University had now gone to West Philadelphia, and this fine new hospital at last afforded ample clinical material. On the endowment of the Chair of Surgery by Mrs. Susan R. Barton, widlow of Dr. Barton, in 1578, hy the gift of $\$ 50,0(00$, the title was changed to that of the "John Rhea Barton Professorship of Surgery,"-a title which it still bears.

1)r. Agnew and Dr. Smith had long been as 1)amon and Pythias to each other. For many years they had becu insepalrable companions, always together whenever the opportunity offered. They had always felt the greatest love, sympathy, and admiration for each other.

For many years they remained most intimate in their relations; as has been stated, as far back as $185.5,1$ r. Jenew had been in the habit of substituting for his friend, while he was Professor of Surgery; and still eartier. in 1554, they had been associated together in the work of reopening the philatelphia Hospital for clinical instruction. When 1)r. Sunth was a candidate for the position of Professor of Sureery at the Unirersity of Pemsylvania, in 155.), 1)r. Innew was one of his most earnest workers and supporters. It was. probahly. somewhat thromgh 1)r. Smith's solicitation that 1)r. Lenew (ane to the University. Unfortunately. howerer. 1)r. Agnew's reputation grew so great that it ereatly overshatowed that of 1)r. Sinith. This was not the fault in any way of eitlecr. It was simply the inevitable result when one skillful, famous physician comes 
unconscionsly and slowly into competition with another. Dr. Agnew's progress had been rery slow; he had not forced his way at all; hut, coming as it did, simply the natural growth and demand of the times, it was resistless even to Dr. Agnew himself. Dr. Agnew never sought the position of Professor of surgery in the slightest way; nerer by word or deed did he intimate that he wanted it. IIe would have been satisfied for them to have retained their old relationship. As he said in his furewell speech, at his last didactic lecture, "The post was one that I had never sought."

The opportunities for clinical instruction at the University Iospital opened the way for the appointment of a Staff of 1) emonstrators of Practical Surgery to assist Dr. Agnew. They were: 1)rs. Hunter. Willard, Muhlenburg, and Elliott Richardson. Iater, the Surgical Dispensary's staff was increased, Dr. Charles T. II unter being made Chief. His assistants were: Drs. Stryker, Muhlenburg, Ashbridge, Allison, Willard, Richardson, and l'orter.

The second civil hospital with which Dr. Agnew was connected was the Wills Eye IIospital. He applied for this position in order to romed out his surgical experience.

It a stated meeting of the Board of Managers of the Will Ilospital for Discases of the Eye, held Jamuary 4, 1864, with the President, 1)r. Paul, in the charir, the Board elected, as attending sureons. I) lavis. and 1). Inyes Annew. The management of the hospital wats aranged in such a way that it required the ammual election of its medicall officers; therefore, on Jamuary 2, 1865, I)r. Agnew wats redected. Ilis third election ocemred December 3, 1866. () september 7,1868 . I)r. Annew's resignation was received and acepted, 1)r. Ilarlan being manimously elected to fill his position. ()n October 5. 1465. a complimentary Minute was adopted by the board of Mamager, in which they placed on record their high entimation of I)r. Agnew's professional services in comnection with that institution. He was made Emeritus Surgeon to the hospital, remainin? $\cdots$ 
As there is a complete record kept at the Wills IIospital of the major operations performed by the different surgeons, it has been easy to complete Dr. Agnew's record of eye-work during his term of service. In comparing it with the work of the present day, it must be remembered that the accommodations of the hospital have grown considerably since his connection with the institution; for example, in the month of January, 1864, there were only $38 \mathrm{new}$ patients admitted to and 38 discharged from the house, while the total number of new out-door patients was 119. The number runs now four times as great for house patients, while out-door patients number orer 1000 monthly. In addition, Dr. Agnew's terms of service were principally during the summer months of these years, affording the smallest clientele; yet he performed, during this short period of time, 69 operations for cataract, 15 iridectomies, 24 tenotomies, 5 divisions of the ciliary muscle, and 1 enucleation. This shows that a very large percentage of his work was operative.

Undoubtedly, the most important position held by Dr. Agnew, as far as concerned purely operative surgical work, was his comnection with the Surgical Staff of the Pennsylvania IIospital. This institution, from its location, from its size, and the length of time it has been in operation, is casily the first of the Philadelphia hospitals, and its staff of physicians has always consisted of the leaders of the profession in Philadelphia.

Philadelphia, one of the largest mannlacturing cities in the United States, is the scene, daily, of comtless accidents. Her busy streets also trem with the ordinary dangers of city life, and the extent and variety of her population aftiond material for the study of diseases of every linul. It is opportunitics of this sort which constitute a centre for medical education. These facilities have been recognized from the earliest ding of medieal study in America. The Pemnsylumia Hospital is trpical of Philadelphia; within its colonial walls the greatest vitricty of acute diseases, accidents, and curions medical phlates of Philadelphians have been found, from the days of Gabricl and Evan- 
geline down to the present time. Its quaint buildings and pleasint prounds caused the poct Longfellow to end here the carere of these two famed lovers, the hero and heroine of the gratest Imerican poem ever witten.

While a nember of the Surgical Staff of this hospital, 1)r. Ignew was given a practical opportunity to demonstrate the dewere of fidelity which he held for his convictions. The circumstances of the occurrence are as follow: He was elected a member of the Staff of Attendiug Surgeons to the Penusylvania IIospital on March 27, 1865, serving in this comnection, acceptably. for six years. On May 29, 1871, a resolution was pawed ly the Board of Managers of the Pennsylvania Hospital. requesting the staff to give appropriate clinical instruction to the students of the Women's Medical College. This question had long leen discrisocel by the management of the hospital, and the following are the details in connection with it:-

"()n motion of Samuel Mason, the following resolution was offered at the meeting of the Board of Managers of the Pennsylvania IIospital:-

"The Contributors, at their anumal meeting in filth month, 1870, having directed that appropriate thorongh clinieal instruction be given to the stmlents of the Women's Medical College, if practicable, at the

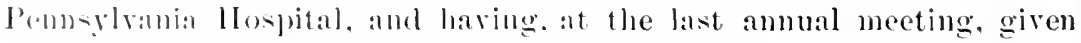
reitidaterl intructions to the same eflect,

"litsolved, 'That it is helely mane the duty of the Medieal and Surgicall stall to cally into enlect the instructions given by the Contributors, ats alwe mentioned, during their term of oflice.

"Yois 6. and Nays 5. Those who roted in the affirmative Wore: John Fammm. William Biddle, Samuel Mason, Samuel IVish. Iomjanin 1I. Shoomaker. Mordecai 1. Dawson. Those voting unatively were: Alexander J. Derbyshire, Jacob P. Joner. Alexinder Bidelle. Joweph B. 'Townsend, and Joseph C. 'Turnumenis."

Thi- aretion having heom taken by the Board. they received, at the same meeting. the following letter from Dr. 1). Hayes Agnew:- 
Mr. Jacob P. Jones.

\section{Chestnut Street.}

Dear Friend: Should a willingness to give surgical instruction to female students be required as a condition of election on Monrlay, I desire that you will do me the favor to withdraw my name, as I should regret to do anything which would embarrass the Board in earrying ont the wishes of the Contributors.

Very truly your friend,

D. Hayes Agnew.

Immediately upon receiving this communication, the following resolutions were passed by the Board of Managers:-

"Whereas, A communication has this day been received from Dr. D. Hayes Agnew declining to be considered a candidate for re-slection if surgical instruction be given to female students, in accordance with the directions of the Contributors at the last amnal meeting; and

"Whereas, The Board feel bound to carry ont the instructions of the Contributors; therefore,

"Resolved, 'That in accepting the declination of Dr. Agnew the Board desires to express their deep sense of his eminent abilities as a surgeon, as well as the faithful manner in which he has discharged the arduous duties devolving upon him while connected with the institution.

"Resolved, That a copy of the above he furnished Dr. Agnew, signed by the President and Secretary on our behalf."

Dr. Agnew, consequently, was not a member of the Staff of the Pennsylvania Hospital for the next six years. During this period he devoted such time and energy as was not spent in practice on his work in comnection with the University of l'ennsylvania. On the Tth of May, 187\%, howerer, he was re-elected to the Staff and served for over six years, resigning, eventually, April 17, 1884.

It was always understood by $\mathrm{D}_{1}$. Agnew and his friends that his re-election to the Staff of the Pemnsylrania IIospital meant also that female students would not be allowed to attend his lectures, as that was the ground upon which he had resigned six years before, and as he still retained the same views. It has been discovered, however, recently, thit when he resumed duties at the hospital no stipulation in regand to the presence or absence 
of female students was put upon record in the Minutes of the Board of Managers, although a suggestion was made in the Board, at the time of re-election, that women should not be present at his lectures, or should be asked to withdraw if, in the judgment of the lecturer. an operation was to be performed which he considered untit for their presence. Dr. Agnew resigned on the rery day that the resolution was passed by the Board allowing female students to be present at the cliniques at the Pennsylrania Iospital, and he did not change his views in liter years. Consequently, his comnection with the Pennsylvinia IIospital at this later period needs explanation. It is mondoubtedly shown in the following letter of acceptance, which is copied from the Minutes of the meeting of the Board held May 28. $187 \%:-$

1011 Chestedt Street.

To the Board of Managers of the Pennsyleamia Hospital.

Gexteanex: I an deeply tonehed ly both the compliment and the confidence implied in the recent action of your Board in electing me, without solicitation on my part, and with singular manimity, as one of the sll weons to the institution over whose interests you preside. Thongh presch with many arluons and exacting duties, yet, uncler the ciremmstancer, I do not feel at liberty to recline. and shall, therefore, enter upon lhe lutios of the place with the determination to serve the hospital to the best of my alility.

With comsiclerations of the highest respect, I am, respectfully, your oberient servant,

D. HAYES AGNew.

From this letter it can be seen that Dr. Agnew was rerlected without solicitation for the position and withont stipulatim on his part. and tlat, consequently, he took it for granted that the Buard intended to remove the obstacle which had ranced his separation from the hospital some years before. He wal a man to meet such an action half-way. He knew that the boand could not have been led to believe that he had changed his malterable determination not to lecture to women students. Ite believer that they had come orer to his views in the matter, and he wisely let further discussion drop. After, 
consideration of these cireumstances, it can be seen that the Board of Managers of the Pennsylvania Hospital, by re-cleeting him, retreated from the position which they had assumed some years before.

After his election there were, undoubtedly, a number of female students who attended his leetures, but he interpreted their presence to ignorance of his riews on the subject; and, moreover, he was entirely too courteous and lindly in his feelings toward every one to object to the presence of the women, -if he found them in his clinique-room,-even if they overwhelmed him.

In order to see whether Dr. Agnew's belief in regard to cliniques in which male and female students were admitted was wrong, it is neeessary to know of what a clinique consists and who the students are. From time immemorial it has been customary, at the surgieal cliniques, to display the cases of renereal discases which are present in the hospital, and study them carefully; this forms a part of the regular instruetion of a surgical clinique. In order to study these cases thoronghly, it is necessary, of course, to enter fully into the minutest details of the diseases, their causes, diagnosis, and their treatment, making, at the same time, the neeessary exposure of the patients. The ntmost fieedom of speech and actions is required. On the other hand, the audience which is to view this exhibition is not composed of physicians, but of young men and women who are studying medicine.

The large majority of such students who attend clinical lectures at such an institution ats the Pennsylvania Hospital are the new-comers at the medical schools. 'They have not become fully aceustomed yet to the sights and work to which every practising physician has long been fanilials. There ean be found among them many young men and women who are not of mature age, - some of the students being fiequently as young as seventeen or eighteen years of age. 'Taking such a mixed class as this, eontaining many boys and girls unaccus- 
tomed to such work, and exposing to them the umpleasant sights and facts of rencreal diseases, is a task from which a modestminded physician would naturally shrink.

1)r. Agnew did not wish to deprive the female students of an opportunity to study these diseases; simply he did not think that the "mixed clinique" was the proper place for them to acquire this knowledge. In this belief Dr. Agnew did not stand at all alone. A great number among his friends and colleagues have taken the same ground.

1)r. Annew's belief in regard to female medical students is a corollary of his ideas on the subject of women studying medicine. Dr. Agnew was not opposed to the higher education of women. IIe believed that the ideal place for woman was at home. as the head of the houschold, but he realized the fact that such a position was not intended for all women. He held the sex in great respect and consideration, and he did not belittle their powers or capacity for work.

I)r. Agnew did not oppose the admission of women into the medical profession. The field of medicine is so broad, and there is so much room for minds of the most diverse dispositions and talents, that he realized that there were certain branches of medicine to which they were peculiarly adapted, such as the preparation and mounting of microscopical specimens, where their delicacy of touch and deftness of fingers made them woll adapted. He bclieved that their minds were sufficiently powerful for them to grasp the amount of learning and training necessary to pass successful examinations; but he had a decp, insurmountable distrust in the ability to train the special talents of woman into the attributes of the really successful prectising physician. He did not believe that, either naturally or by their centuries of inherited training, women made rood prictitioners. In a similar way he did not believe that men made good nurses, no matter how well trained; and, if he could aroid it, he never employed a male nurse. In addition, he belioved that the environments of society were arranged 
in such a way, at present, that a woman could not practise medicine without being exposed to many hardening, unpleasant influences.

At the same time Dr. Agnew recognized the futility of opposing the admission of women into the practice of medicine. If the State would allow them to practise, and they cared to study and could obtain a sufficient number of patients to make the practice of the profession profitable, he knew enough of the world's ways to realize that his protest would be mavailing; so that, when any measure came up in which he felt that they would be successful, he did not attempt to defeat them; for example, at the time of the last agitation of the question of the admission of women to the Philadelphia County Medical Society he listened courteonsly to the statements of the then-existing status of the question as seen by the women physicians, and expressed his entire willingness to let the morement take its course, saying that he should make no objections to the admission of women, should the Society see fit so to rote. When it was proposed that the women of the medical profession in and around Philadelphia should give a reception to Dr. Hiram Corson, Dr. Agnew allowed his name to go on the joint committee of medical men and women without a moment's hesitation.

Dr. Agnew served at the Pennsylvania Iospital, after his second election, until April 1\%, 1884. It is a strange coincidence that he served as a surgeon at this hospital for a short time over six years; he was ont of office six years. and on his return to service he remained on the staff again for six years.

Dr. Agnew's appointment at the Orthopedic Ilospital came next in point of time.

Although in Europe, by the year 1867, there were a few hospitals devoted to the science of orthopraxy, yet in the United States there existed no such charter institution for the treatment of bodily deformities. There were. of course, operations performed for club-foot, etc., at all the cliniques of the large hos- 
pitals, but the after-treatment of adjusting proper apparatus, the constant manipulation and rigilance necessary to prevent recurrence after operation, could not always be fully carried out, due to the very limited accommodations existing in general hospitals for this purpose, and to the fact that few hospitals were able to defray such expense. Thus many cases of club-fect among poor children were operated upon with necessarily ill attention later. Often the apparatus was left off, and in some cases the contractions following the operations produced worse deformities than the original. Drs. Thomas G. Morton, H. Earnest Goodman, S. W. Gross, and D. Hayes Agnew, believing that such an institution had long been needed in Philadelphia, took up the movement for the accomplishment of this purpose. In consequence, these four gentlemen met, October 1, 1867, to advise as to the best means for a hospital for deformities in this large and constantly increasing eity.

A charter liad been prepared and a second meeting was held October 11, 1867, and 1)rs. Agnew, Morton, Goodman, and S. W. Gross consented to act as a board of surgeons, with Professors S. D. Gross and George W. Norris as consultants. At this meeting a committee was appointed to confer with those gentlemen who had consented to serve as managers of the hospital. On October 23, 1867 , the attending surgeons, with 1)r. S. 1). Gross, met Edward Hopper, Dillwyn Parrish, and Joseph ('. 'Tumpenny, when the following Minute was read and alopted :-

"Wherbss, There exist in all large communities many persons suffering from hodily deformities, snch as lunchback, hip disease, elub-foot, knock-knec's, wryneck, etce; and

"Wruekess, A large proportion of such persons of adult age seen in our streets have never received in eary life the requisite treatment for such deformities; and

"Whereas. Such deformities require constant care and attention by operation and mechanical appliances for greater or less period of time; and

"Wueras, No institution now exists in this city" or state speeially devoted to the treatment of this unfortmnate elass, and believing that 
many persons may be saved from growing up deformed and a burlen to society, by a scientific course of treatment in a well-organized Orthopædic Hospital, we, citizens of Philadelphia, trusting in the liberality of the public for support, met in Parlor No. 9 of the La l'ierre House, on Wednesday, October 23, at 5 o'clock P.M., for the purpose of organizing an Orthopedic Hospital tor the cure of such deformed persons as hereinbefore mentioned."

Mr. Edward Hopper was appointed temporary chairman and Dr. Goodman was appointed acting secretary of the Board.

The charter prepared by the medical gentlemen was revised, and while waiting its approval, which took place by "An Act of the Court of Appeals" in December, 1867 , temporary quarters were opened at 15 South Ninth Street, over the surgicalinstrument establishment of Mr. D. W. Kolbe, who had been active in the suggestion for its establishment. The hospital was opened for the reception of patients on February 25, 1868. Only out-patients were then treated, while funds were being solicited for the establishment of a well-regulated and organized hospital.

The first Board of Managers appointed under the charter consisted of Edward Hopper (president), J. Gillingham Fell, Charles Macalester, Samuel S. White, Judge William s. l'ierce, Dillwyn Parrish, Joseph C. Turnpenny (treasurer). ('harles F. Norton, James B. Nicholson, J. B. McCreary, 'Thomas (i. Morton, and D. Hayes Agnew. ${ }^{1}$

Thus, Dr. Agnew was a member of the first Board of Managers, and, at the same time, served as sureen on the Medical Staff. The other surgeons were I)rs. Thomas (i. Morton, H. Earnest Goodman, and S. W. (iross, with I)rs. S. I). Gross and George W. Norris as consultants. The hospital rapidly increased in size and usefulness, althongh at the beginning of the second year only form beds cxisted. The mission of the hospital was so well carried out that only $\$+8$ remained in the

1 A group photograph of these gentlemen, tugether with those of Prof. S. I). Gross, George W. Norris, M.D., and S. W. Gross, M.D., consulling and attending surceons, and D. W. Kolbe, now hangs in the Board-room of the new hos pital. 
treasury at this time. Each year showed an increase in the number of patients treated and operations performed. Drs. Morton and Goodman did the largest part of the operative work, while Dr. Agnew held the position of influence and help rather than that of active operator. On account of the increase of his other duties, Dr. Agnew resigned his position as attending sulgeon in 1871, at which time he became a menber of the Faculty of Medicine at the University. Since that time, Dr. Annew held the position of consulting surgeon up to the time of his death.

In the fall of 1870 a department for nervous diseases was created, to which were elected plysicians for this work. It was thought adrisable to treat these two classes of disease in the same institution, because of the relation many of the deformities bore to nervous diseases, and as many cases of nerrous disease exacted at some time the use of instruments to aid in locomotion.

In 1872 the hospital removed to its new quarters, where it still remains, at the northwest corner of Seventeenth and Summer Streets. The other consultants with Dr. Agnew, during this period of serrice, were Drs. Gross, Norris, Hunt, Morehouse, and Keen.

From the founding of the institution up to November 30 , $189 \%$, there have been 11,560 surgical cases and 11,850 nervous cases treated at the daily clinique, with 3235 cases that have received house care, making a grand total of 26,645 cases treated since its foundation.

Thus it was that he grew gradually from the Master of the Anatomical School to the clear-voired professor, the clinical teacher with marvelous hands, and the trusted surgeon of cnormons practice, known from sea to sea, from the lakes to the gulf, as the last great appeal in practical operative surgery.

The professor in lis chair had become a marvel. The most eminent members of his profession gave public testimony to the marvelous clcarness of his statements, the sound common sense of his teaching, the reliable data founded upon his 
own operations and observations; the large forecasts, wonderfully suggestive and helpful, which he threw out before benches of eagerly listening students, and the inspiration to faithfin work which he continually breathed into those who hearkened to him.

He became the consultant of consultants. The best men of his noble craft felt in their souls that Agnew had won all that he knew, and, pouring out rolumes of proof for what he stated, would lead them ever in safe paths.

During this period Dr. Agnew changed his residence. He remained on Eleventh Street for orer sixteen years. As years rolled by, however, the centre of residences had moved westward. Dr. Agnew finally concluded that he should go with it. Accordingly, in 1866, he purchased the house, 1611 Chestnut Street, combining, curiously, the figures of his former home,-16 North 11th Street. He lived in this house for nearly twenty-one years, - until the fall of 1886 . It was an excellently timed selection, for it placed him again in the centre of the best section of the city, - a most fortunate thing for a physician. 


\section{CHAPTER VII.}

\section{Dr. Agnew as Professor of Surgert.}

Dr. Agrew's appointment as Professor of Surgery at the University of Pennsyluania was made May 2, 1871, by the Trustees. He began now to carry fully into effect his ideas on the teaching of surgery. He was a firm believer in actnal experience and observation as being the best means to impress students with the principles and practice of surgery. He increased the size and scope of the Surgical Dispensary and added a corps of Demonstrators of Surgery.

The University of Pennsylvania had decided at this period to change its location to some such position which, while adapted fully to its purpose, would be permanent. Consequently, steps were taken to settle in West Philadelphia, on the strip of land extending sonth from Thirtr-fourth Street and Darby Road.

In the meantime the Medical Department left their quarters at Ninth and Chestmut Strects in the spring of 18r3. The winter of 1853-it was spent in the building, 252 South Ninth Street. formerly ocenpied by the Philadelphia University of Nedicine and Surgery. They remained here until June, 1874.

The first course in the new quarters in West Philadelphia becan Oetnber 12,187t. The Hospital which had been erected was inalugurated by Govemor Hartranft in 1874 and opened for patients. There was some trouble experienced at first to place the officers of the Medical Department and those of the Inspital on a satisfactory footing. This was finally accomplished by making the professors of medicine, surgery, and ob-tetries ritoficio officers in the hospital and making the profixiors of clinical medicine, surgery, etc., members of the Faculty. This was done in Mareh, 1875. On March 6, 1874, I)r. Jolm Neill was appointed Associate Clinical Professor of Surgery by the 'Trustees. 
Dr. Neill retained this position for several years, until his election to the position of Emeritus Professor. He was succeeded by Dr. John Ashhurst, Jr., who was elected, June 5, 1877, by the Trustees to the position of Professor of Clinical Surgery. Dr. Ashhurst retained this position until Dr. Agnew retired from active service, in 1889 , when he was adranced to the John Rhea Barton Professorship of Surgery.

During this period of the reconstruction of the Medical Department, Dr. Agnew took an active part. He bore, to a large extent, the burden of the responsibilities of the financial questions arising from the increase of size and consequent expense. The Minutes of the Faculty meetings of this period, meagre as they are, are filled with references to Dr: Agnew's work on these questions.

The organization and successful formation of the Dental Department was entered into by Dr. Agnew with great interest. Some influential members of the Faculty strongly opposed such a venture; it is interesting to note that Dr. Agnew was a member of the various committees appointed to orercome these objections and remove this opposition. The successful cstablishment and operation of this department since $18 \pi$ it show the soundness of this judgment of its suggesters and promoters.

The Faculty meetings were held the third Monday in each month, at the homes of different members. Frequently they were held at Dr. Agnew's residence. 1611 Chestnut street.

By Dr. Agnew's suggestion, orthopedic and venreal dispensaries were established at a meeting of the Faculty. June 29, 1877. By these two cliniques, an immense amount of work has been done. The Spring course of lectures inaugurated in 1878 was strongly adrocated by I)r. Agnew, and to him was left the selection of a number of its lecturers.

He asked during this time that some remuncration be given his demonstrators of surgery, four in mumber. In consequence, the sum of fifty dollars ammully to each was roted as salary. Following out his ideas of actual experience in teaching, he 
inaugurated the system of teaching bandaging and fracturedressing to first-course students.

During this period of 1)r. Agnew's comnection with the Faculty, there was a very wide difference of opinion between those who regarded the curriculum as the best possible, and those who, on the other hand, thought it, on principle, the worst possible, and only redeemed by the honesty of those who ignorantly employed it.

Dr. Anuew was never far from the front of the party of progress, and he did much, by the impression of his earnest convictions, to encourage some who felt their spirits fail in the apparent hopelessness of the conflict. Apart from this special question, it may be safely asserted that in the Medical Faculty there was no one whose judgment was held in higher esteem by all of his colleagues; for it was always temperate, deliberate, and untainted by any expression of selfish interest.

'The following estimate of Dr. Agnew's services in the Faculty of Medicine at this time is prepared by the Provost of the University :-

"I)r. Agnew's powerful personality made itself felt, in the work and development of the Medical School of the University of Pennsylrania, from the beginning of his comnection with it down to the last days of his life. His great suceess as a teacher has been fully referred to elsewhere in this work. I remember well, in my student days, the admiration and derotion which we felt for him.

"When he was added to the Faculty of the Medical School it was felt by all that he would be the peer of the great men who have honored the chairs they held in that school. This expectation was more than realized. He grew and dereloped teadily year by year, both as a great teacher and practitioner of surgery. It is not for me to allude to the magnificent reputation he achieved at lome and abroad, or to the great work that he did for the community at large, and for surgical science. I am more especially concerned with his personal relations with 
the Medical Faculty, and with his influence upon the progress and growth of the medical sehool.

"He was admirably faithful in his attendance at Filculty meetings, and showed there the same conscientious care in the discharge of every duty that marked him in all relations of life.

"The last fifteen years have witnessed a complete reorganization of the Medical School of the University. Large interests were concerned and there were honest differences of opinion as to the wisdom and safety of the progressive policy pursued. I)r. Agnew's attitude was unswerving. He believed in honest, thorough work in education just as he did in every other field of effort. Medical teaching, with him, was a saered trust. Its duties never sat lightly upon him. He welcomed every substantial advance in the interests of the science and of the students, no matter at what increased cost of personal exertion. Just as we know his open and impartial mind made him among the first to welcome the great truths of modern antiseptic snrgery, so he accepted with equal readiness and completeness, as soon as convinced of their soundness, the adraneed riews upon medical education.

"It was most fortunate that in Agnew, Leidy, and stillé the Medical Faculty contained men whose nimes and characters were towers of strength during these years of struggle.

"Dr. Agnew's personal relations with the members of the Faculty were so affectionate; their ronfidence in his sincerity and disinterestedness and genuine sympatly was so great that his advocacy of any measure went fir to secule its suecess. Th is influence in the councils of the Fandty was, therefore, powerful, conciliating, and elevating. No one who had not the privilege of frequent personal and official intercourse with him ain fully appreciate the charm which his character and consistent conduct conferred upon such relation.

"In the actual work of the Mfedical School his servires and achievements were fully as conspicums. He was an ideal teacher of surgery. In the first place, he kipt his appointments 
with his class with scrupulous fidelity. At a time when every minute of his day was of golden value and was greedily sought in all quarters, he would travel all night and subject himself to every fatigue and exposure, or would unhesitatingly sacrifice the most important and herative consultations rather than miss a lecture or keep a class waiting. The high purpose he had in teaching impressed every student. There was no display of himself, of his vast attainments, or of his marvelous skill. He said only so much as would best instruct the student, and he did only what was demanded by the best interest of the patients upon whom he operated before the class.

"He taught not only by what he said and did, but by what he refrained from saying or dloing. I am sure that, during his long career as a teacher, not one word was uttered nor a single operation performed which was hasty or ill-advised. His students depended upon his teachings with that fullness of confidence which is the highest tribute to any teacher. This trust in him began in their earliest student days, and it continued in all their subscquent relations with him after they had entered upon the practice of their mofession. 1Ie clid, at least, as much as any other man to sustain and carry forward the fame and success of the Medical sehool of the University during all the years he was comnected with it.

" He threw himself into the movement for the establishment of the University IIospital with characteristic energy and dirertness of purpose. It is, indeed, fitting that the splendid portrait of this great master in surgery shonld adorn the hallcntrance to this great hospital which owes so much to him.

" Ilis best thought, his valuable time, his personal exertions were always at its disposil. In the adrocacy of its claims before the state legislature; in personal appeals to his numerous frimds in behalf of its funds; in generous personal gifts to it which only heralded the munificent benefaction announced in his last testament, he displa yed a love and solicitous anxiety for its welfare and growth which were of incalculable value. 
"His name and memory will forever be inseparably associated with the Medical School and the Hospital of the University of Pennsylvania, and they will be cherished there as a glorious example to the Faculties and students of all coming times."

In 1861 Dr. Agnew had been given thie honorary degree of A.M. by Princeton College, as a mark of appreciation for his work in advancing the position of surgical science. This college, ever friendly to him and his ambitions, conferred on him, in 187 , the honorary degree of LL.D.

In the summer of $1872 \mathrm{Dr}$. and Mrs. Agnew went abroad to remain a few months. The details of this trip are given in another chapter. They were accompanied by Ior. Agnew's assistant, Dr. Charles T. Hunter. Dr. Hunter was regarded by Dr. and Mrs. Agnew almost in the light of a son; he stood easily at the head of the corps of assistants, and his death, in 1884, was a terrible shock and irreparable loss, for, not only did Dr. Agnew feel that he had lost a brilliant assistant and loving companion, who was bound to him by many tics, but he realized that Dr. Hunter's place could never be filled again so ably and satisfactorily.

During this time Dr. Agnew continned his occasienal contributions to medical literature. In 1865 was published his essay on "Lacerations of the Female Perinenm." in which he reported a new operation for the relief of this condition, devised by himself. On July 6, 1866, he began the scriess of palpers in the Medical and Surgicul Reporter on "Vesico-Taginal listula," which was subsequently reprinted in pamphlet form in $186 \%$. In 1882 he combined and rewrote these two essays and published them in book form, through the firm of Lindsay \& Blaliston.

This book stands as a landmark in grnecology. In all good historical accounts of advance in this branch of surgery its force and advancing influence is noted. In such standard works as Mann's "System of Cignecology," the proper importance of this work has been recognized. 
1). Agnew increased at this time his fame as a syphilographer; he became the authority in America on this division of medical work.

1)r. Agnew delivered the introductory lecture, October 10, 1870, to the incoming class at the Medical School. During the period 1869-71 reports of his clinical work were published in the Hedical aml Surgical Reporter; by Dr. De Forest Willard. Dr. Willard collected the data of many cliniques, and by rearrangement was enabled to report one clinique on the various phases of one disease, operation, etc., making the cliniques more valuable than when published as delivered.

The number of papers on anatomy in its relations to surgery and medicine reached sixty by 1864 , but, as has been stated before, at this date they stopped forever.

IIe delivered an address to the Philadelphia County Medical Society, January 5, 1875 , when retiring from its presidency. IIe took as his subject, "The Results of a Series of Experimental Observations Comnected with the Repair and Development of Bone.Tissue." 'This essay was afterward incorporated in his work on surgery. In this work he was assisted by Drs. Charles 'T. IImter, Henry C. Chapman, and James Tyson.

In 1876 he was selected to deliver the "Address on Surgery" before the Pennsylvania State Medical Society. Later, when President of this body, he delivered an address on "Errors of I)iacnosis."

l)ming this period the great literary work of his life was begun, "The Principles and Practice of Surgery," which was issued in three rolumes. The first rolume of Dr. Agnew's "Surnery" was published in 1878 , the second volume in 1881, and the third in 1853. The mere mechanical labor involved in writing this work was tremendous. There were over 1100 panes in the first and second rohumes, and nearly 800 in the third, making a total of 3000 pages. As each page contains, on an average. 650 words, this makes a total of nearly $2,000,000$ words for the entire work. 
As Dr. Agnew wrote the entire book with his own pen, allowing that he could write ten words a minute, which was far faster than he worked, for he was constantly compelled to reeall cases of his own, to consult other authorities, and do similar work, which makes the progress of such a work extremely slow, it would take 3333 hours of constant work to produce it. Allowing eight hours as a working day, this would keep him occupied steadily for 417 days. He was engaged many years upon the work, doing it at odd times, such as working late into the night and getting up early in the morning, working before bis early breakfast. The tremendous resources of his ritality may be better estimated when it is realized that this work was done at the very time of life when he was busiest in practice, busiest at the University, and busiest in consultation work. The work on the second and third volumes came about the time of the Garfield case, which added to his already tremendous routine of work. The number of illustrations in the work are 2198, each one of them being selected for its appropriateness, and the majority of them being original to the work. In order to show the tremendous range of the subjects treated, it is interesting to note that the index of the three volumes occupy seventy-three pages.

The opportunities which gave Dr. Agnew the albility to write this work are unique in the history of surgery. It has truthfully been said that never again ean such a work on the subject of surgery, with all its broad ramifications, be produced from one man's experience. Dr. Agnew began his surgical work before the introduction of anesthesia, and he was able to keep pace with the advancement of surgery in all directions. Such an opportunity did not exist before his time, and no surgeon now can keep in tonch with the entire subject of surgery, for the field has grown too vast. In this ability to keep in tonch with the entire field of surgical activity, Dr. Agnew stands in the same position to surgery that 1)r. Leidy did to biology. No worker in either of these fields caln ever hope to occupy 
their pre-eminent positions. "Agnew's Surgery" is the medical diary of his professional life for fifty-one years. In this work he has recorded his own views upon every surgical subject, giving the history of countless cases of his own, his experiences, and his conchusions upon every surgical procedure.

'This makes the work invaluable to the surgeon, for it gives him an Annew perpetually at his elbow. A busy practitioner opening its pages never fails to find clearly-drawn lines for diagnosis, useful directions for treatment, carefully-delineated deductions in regard to operation, and positive opinions as to the arouments for and against operations; for Dr. Agnew knew as well when not to operate as when to cut, a quality not possessed by all surgeons. While Dr. Agnew endeavored to express his own views independently on all subjects, as far as was consistent with the scope and limits of the work, he recorded the views of other writers, that different plans of treatment might be contrasted. A student finds in its pages, also, well-selected notes of medical history and the famous and curions surgical appliances of former days; but through the whole work rums the distinctive thread of Agnew's own personal experiences, from which his thonehtful and practical brain had gleaned so much. Although he never obtrudes himself into the work, yet his own individuality stands out most markedly. It is written in much the same mamner as he lectured. He was instinctively a teacher; when he theorized, his thoughts at once carried him to some practical concinsion.

I) ming the last fow years of his life the spirit of extraordinary vitality which pervaled every department of medicine was most active in the domain of surgery. During these years 1)1. Innew was not an ille spectator, but he carefully watched all that oecured within the region of his special study, and, consequently, he felt that a revised edition of his book should be published, in which he could embody whatever new things, by observation and experience, appeared to him worthy of professional confidence. Early committed to the parasitic theory 


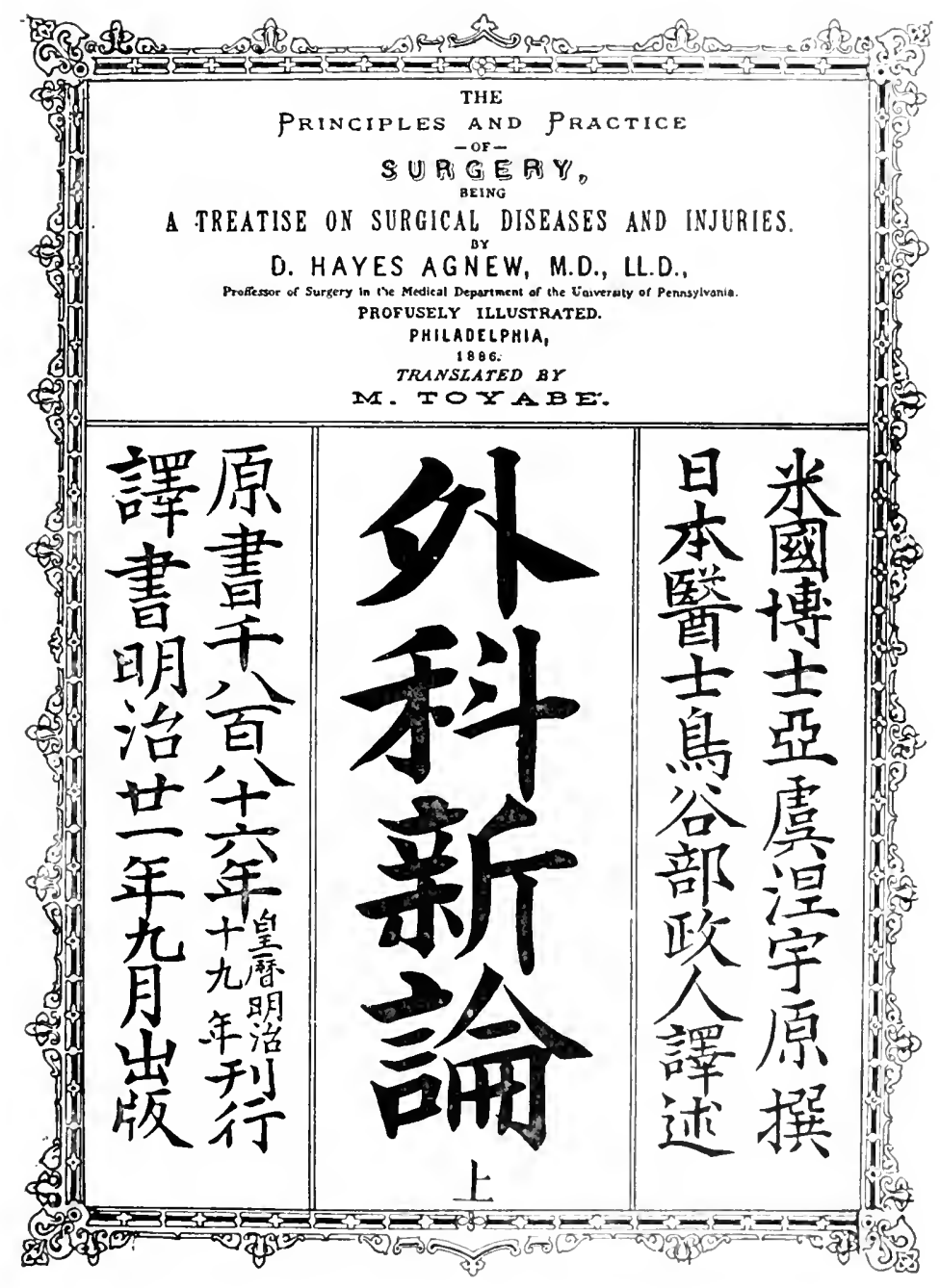

Fac-simile of Tithe Page of tapanfer Fition of

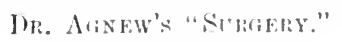


of disease, and adopting methods of practice in harmony with its acceptance, every year but served to strengthen his fiith in the value of the germicidal agents of aseptic and antiseptic surgery. He realized that the medical statistician must begin anew to collect and formulate surgical data, in order to arrive at conclusions which would be trustworthy at present. Consequently, in 1889 he revised his work and the second edition was published. He was surprised, when he came to the actual work of revision, how little he had to change in his words written before the introduction of antiseptic surgery.

After his death the publishers of the work, The J. B. Lippincott Co., feeling that there was a necessity again for its revision, suggested that the work be done. As the ownership of the work was left to the trustees of the Unirersity, they discussed this matter, but at the wishes of Mrs. Agnew, who felt that this monument to his life-work should stand as he had erected it, they decided, permanently, that it should go down to posterity as it had been written by Dr. Agnew, being the most complete and exhaustive description of one man's surgical experiences in the history of the world.

In 1888 Dr. Agnew's "Surgery" was translated into Japanese, and published in Tokio, Japan. The farc-simile of the title-page of this work in Japanese is given on the opposite page; according to Japanese customs, it is at the back of the book. The translation of this page begins at the upper righthand comer and reads downwarl, the Japanese worls saying: "The American edition by Dr. I). Hayes Agnew. Translator, the Japanese Doctor, Nasahito Toyabe." The larger marks in the central column are the title of the book,- "New 'Treatise on the Principles and Practice of Surgery." The figure at the bottom of the page is a word used to signify the first rolume of a set of two or three volumes, meaning, literally, "top," as Japanese books are piled one on top of another, instead of being placed side by side. The left-hand column says: "The original was published in 1886, the translation was made in 
1888 "; or, in the Japanese method of writing dates, in the twenty-first year of the reign of the Mikado.

On the second page of the book is a large stamp in red, which corresponds to the American copyright, being the sanction of the gorernment for its publication.

The book begins with an old Japanese motto about the value of scraping bones, eliminating poisons, removing obstructions, and washing uncleamness. Then the translator gives his estimate of the ralue of the book and the necessity for its study by Japanese students. Professor Gross's "Surgery" and this edition are the two great standards on that branch in Japanese medicine. The price of the book in Japanese is \$6, which represcuts in American money about the value of $\$ 4.50$. This is not cheaper in comparison, for probably not more than onetenth of the work has been translated.

Theories change, new doctrines become old, and most medical books, eren the most successful, have a life-time which rarely exceeds in duration that of their authors; but it is safe to say that surgical writers in future ages will still turn to "Annew's Surgery" as a rich store-house of clinical facts and personal observations, just as they do now to the writings of Paré and Chelius, and as pathologists do to the works of Morgagni or Rokitanski.

As a surgeon, Dr. Agnew was fearless, yet conservative; not shrinking from any operation, however hazardous, but never eager to operate, and always glad if he could see a way to cure the patient by bloodless methods. His honesty and candor in this matter of advising operations may be seen by his recorded jutgment as to the so-called radical cure of hernia. It is well known that in his earlier days Dr. Agnew had himself devised an operation for this purpose,-one of the most ingenious of the many ingenious procedures suggested for the cure of this incurable affection, - and that this operation he had performed in a number of cases with excellent immediate results; had he been a surgeon less judicious in conservativeness, less severe in 
his conscientiousness, or more sanguine in his prognostic habits, he would, no doubt, have continued to resort to it to his own manifest pecuniary advantage, if not to his patients' permanent benefit; but experience convinced him that its ultimate results did not justify its dangers, and he not only abandoned it, but publicly declared that he made it no exception in professing his profound distrust of all operations of this character.

In no phase of his career did Dr. Agnew appear in a better or more favorable light than in his position as a consultant. As a consulting physician, undonbtedly, he stood as a model. He happily accomplished the ofttimes difficult task of being perfectly loyal to the doctor, while being also loyal to the interests of the patient,-for the consulting physician occupies a most delicate and perilous position for all concerned. 'T'his position is rarely raalized by any one but the physician who has been tried in such a capacity.

Dr. Agnew's mamner was perfection. While he examined the case thoroughly, quictly, and exhaustively himself, he showed at all times a proper deference for the feelings and opinions of the physician who called him in. He never attempted, at any time, to place the attending physician in any unfortumate or mcertain light. If he felt that an crror of diagnosis or treatment had been made, he suggested a change to the attending physician in such an adroit and pleasant way that the physician himself frequently felt that it was his own suggestion.

Dr. Agnew's appearance was always such as to command respect. Nearly every one who saw him, and did not know him, asked, instinctively, "Who is that man?" He had the faculty of impressing erery one at once with his ability and conscientionsness. Colonel Rockwell, the intimate friend and faithful nurse of President Garfield, said, "When I saw D). Agnew at the President's bedside, I felt instinctively that the President was in the hands of a man of power and ability; 1)r. Agnew's personal appearance was just such as I imagined the ideal surgeon should be." 
Dr. Agnew in his lectures used no notes; at least, never more than a scrap of paper with the heads of the various topics on which he intended to speak for the day. He lectured as a diclactic professor three times a week, -on Tuesday, Thursday, and Friday. On Wednesday at 12 o'clock he held his surgical clinique at the University Hospital. where he displayed and diacnosed cases and operated. By long training he was able to lecture on the case and operate at the same time,- a difficult achierement to learn, for it requires the following of two ciistinct lines of thought.

As an operator, Dr. Agnew was skillful, rapid, and successful. His superiority as a surgeon could be seen in his operating, even by the merest tyro, unfamiliar with surgical work. Here he showed to what an extent a naturally adept and skillful operator can be developed by a long training and experience. He worked with the utmost rapidity, confidence, and grace at all times, and yet always without the semblance of haste. He never gave one the impression that he was hurrying, although he showed that he was keenly alert to everything; when he was in the midst of an operation he would not tolerate the slightest inattention, stupidity, or awkwardness on the part of his assistants. It was only at such times that he was imperative and brusque in his minner; he felt that the safety of the patient demanded that everything be sacrificed for his or her case. When he picked up his knife, he had a line of action mapped out; without a flourish or a sweep, his linife sank with unerring quickness to the exact depth he intended, and as quickly was withdrawn. 'There was no undecided dissections, consultations, wonderings, and considerations in this work.

I Iis tall and erect figure was always the first object which caught the eye of the incomer into these cliniques. It is impossible to express his wonderful tranquility of mind and confidence while operating. It made the most difficult feats in surgrery a pleasant task to witness, for he never imparted any sense of uneasiness to spectators or friends. 
At all times he was thoroughly collected in his manner, in the midst of the most startling accidents or incidents. Under the most dangerous conditions he never lost his head, but quickly and quietly adopted the best method of action; for example, one writer states that he well remembers the sudden rupture of an axillary vein during the reduction of a dislocation of old standing at the shoulder-joint. The patient instantly collapsed, becoming lifeless in appearance. A quict but quick movement of the hand on the part of $\mathrm{Dr}$. Agnew placed his thumb upon the subclavian artery. The danger of death from an appalling hemorrhage was averted, and the patient's life was saved.

Again, in an operation for cancer of the breast, in which, through neglect, the disease had far advanced, the glands in the axilla being deeply involved, all at once there was terrific hemorrhage; Dr. Agnew quietly said, "I guess we had better clamp this," applying, as he spoke, a clamp over the seat of hemorrhage. Then he resumed the operation composedly; when it was finished, he said, "Let us see what caused this blecding." It proved to be due to a rupture in the axillary vein, owing to invasion of the cancerous process into its vicinity. He applied a ligature to the vein and dressed the wound, not in the least disconcerted by the appearance of a startling accident which would have umnerved completely many surgeons. Such instances in his career could be quoted in great numbers.

The surgeon's dexterity, unfortunately, is like the work of an actor; for, while it delights and impresses the spectiltors, it is impossible to represent it adequately to posterity. Dr. Agnew's skillfulness was shown as much in little opcrations and in small matters as in greater ones; for example, the way in which he plunged a trocar and canula into it hydrocele, to draw off the fluid contained in it, would frequently create enthusiasm among his students. As this little operation is done without the use of anesthetics, it can be made quite painful if done unskillfully, but when it is well done it is only the first 
shock which is unpleasant. The lightning-like rapidity with which Dr. Agnew would perform this operation, and finish it before the patient was fairly conscious of what had happened,although it is the custom of such a patient to watch the surgeon's hands most anxiously, - was most pleasant to witness.

His recognition of surgical conditions was remarkable, and the acenary of his diagnosis was seldom questioned. He was the recognized comsel of last resort,-the chief-justice of the medical supreme court,-and, whatever difficulty of diagnosis arose, a decision by the "old gentleman," as he was affectionately called, was always decisive. Often in cxamining cases some plyyician would say, "I thint:" so and so. Dr. Agnew wonld invariably say, "It is" so and so. This was not from any cgotism on his part or self-assertiveness, but simply the result of his trining ; lis logical mind, stored with the knowledge of so many ycars' gathering. conld grasp at once a case and pronounce upon it so quickly that frequently it seemed almost impossible that he could have given it proper consideration.

An incident which occurred in the course of the Garfield case typifies exactly his quickness of decision and action. The physicians in consultation upon the case were deciding where the lines of incision should be made to liberate the pus. Some said one place, some said another. Dr. Agnew was the only one silent. He stood, knife in hand, waiting their decisions, for he was to do the operating. The coterie of physicians turned to him and asked his opinion. Dr. Agnew said: "This is where I bolieve the incision should be made." As he said the words he mate the incision.

'There was one result of Ir. Agnew's long experience,-no matter how strange a case appeared, or how rare a thing was seen in medicine. he was able always, from his long list of cases, to compare it intelligently and comprehensively with similar cases of lis own. 'This made lim a most fortunate companion in the study of any rare, obscure, or interesting case. 
He was an example of punctuality; when one had an engagement to meet him, it was always wiser to be ten minutes in advance of the appointment than two minutes late; yet he was never in a hurry. In driring with him through many years, no one ever heard him use a more vigorous expression to his driver than "we must push on."

Dr. Agnew, as has been said, was, in the true sense of the term, "ambidextrous,"-not, as is often the case with those who claim this quality, dividing a limited modicum of skill between two hands instead of concentrating it in one, so that they might with more justice be called "ambisinistrons," but he really used his left hand as if it were his right, taking the knife in either hand indifferently, and often himself unconscious which he was employing. In his early youth he had injured his right hand in such a way as to render it useless for all practical purposes, and this loss of the use of the right hand contimed so long that he was confirmed thoroughly in the practical use of the left hand. Upon the restoration of his right hand to its proper condition its dexterity came back coupled with the equally free use of his left hand. The facility with which he used either hand shonld serve as a lesson to parents to instruct children in the free use of both hands. The crippling of the left hand is a relic of the Middle Ages, when the right hand held the sword and the left the shiekd, and, as a natural sequence, the right hand was the hand of good faith, while the left was the reverse. This is crystallized in the two words dexterity and sinister.

If there were a shade of preference shown ly Dr. Agnew in the use of his hands, it was for his left. Possibly this was in order to preserve the balance of utility. He carried his watch on the right side of his waistcoat, this being the pocket which his left hand would naturally seck with his arm halfflexed. A person who gives preference to the right hand instinctively places it in the corresponding pocket on the opposite side. It has been claimed that this is not a finir test that Dr. Agnew preferred his left hand instinctively. It does not imply 
at all, however, that he used his left hand when ascertaining the time of day, for watches are made for right-handed people. In his use of the scissors, which is a movement very difficult to acquire, he was indifferent as to which hand he used; althongh, in the majority of cases, he preferred to use the left hand becanse his right hand might happen to be oceupied at the time.

It is generally considered an excellent test, in a case of acquired ambidexterity, for determining which hand is given the preference, to observe which hand is used most frequently in writing. Writing with the left hand is an umnatural procedure, as the thumb and fingers that hold the pen hide the letters that have already been written, while with the right hand the writing trails away from the aheady written word, leaving the full line visible. Dr. Agnew almost invariably used his left hand in writing, and, strangely enough, wrote with the back of his pen.

Reade, in "The Coming Man," mentions the wonderful accuracy of the action of the left-hand fingers in the case of a violinist, whose whole skill depends not so much upon drawing the bow backward and forward with the right hand as it does upon that wonderful readiness of tonch that enables him, automatically, to sclect the string and to place his finger, with such marvelous accuracy, upon the spot which will derelop the delicacy and the gradations of tone that are required to make music what it is when developed by the tonch of a virtuoso.

This point, raised by Reade, was seen in the case of Dr. Agnew, for in his younger days he developed great skill in the use of the riolin, which he played in the ordinary manner with the bow in his right hand.

This fondness of Dr. Agnew for the use of his left hand was seen by the artist, Mr. Eakens, when he was painting Dr. Agnew's picture for the University. This painting represents 1r. Agnew at the completion of an operation, and Mr. Eakens, who had been attending his cliniques for several months to get 
his characteristic attitudes and methods of operating, recognized at once this peculiarity.

This slight preference of Dr. Agnew for his left hand does not, of course, detract in the least from his ambidexterity. He could do equally good work with either hand.

In all kinds of surgical work Dr. Agnew was equally happy. He was just as capable of the extremely dclicate work of extracting a cataract as he was in the expenditure of force necessary for refracturing a bone. Skillful in all operations, he was especially so in procedures which required great delicacy of touch, such as the removal of thin-walled cysts, in which his long habit of anatomical dissection came particularly into play.

The following estimate of Dr: Annew's scrvices as a surgeon was written by a colleague and friend of thirty-five years' standing, and his successor in the professorial chair:-

"During the last twenty years of his life it is probable that Dr. Agnew saw more patients in his office and in consultation than have ever been seen by any other Philadelphia surgeon. When it is remembered that he was at the same time constantly engaged in teaching, lecturing regularly during the winter months four or five times every week, it will be seen that he could have accomplished this amount of work only by carefully allotting his time and by being blessed with an unusual degree of physical endurance, cnabling him to clisregard fatigue by which another man would have been completely exhausted. Indeed, it was for years I)r. Agnew's liabit to take a train, after a full day's work, in order to see a distant patient in consultation, making his visit late at night or in the very early moming, returning in time to be at his office as nsulal the next day and to fulfill his lecture engagements at the Unirersity of Pennsylvania.

"Possibly the best way to form an estimate of the position which Dr. Agnew occupied in his profession is to consider what would have been the state of affairs had his personality not 
existed; who can say what American surgery would have been during the last twenty years without his participation? Whether advising as consulting surgeon at the bedside of a wounded and dying President, imparting the principles of his art to large classes of attentive and cager students from all parts of our broad country, or giving the benefit of his great skill to the humblest clinique, his share in the surgical history of his time was such a large one that it is hard to imagine what that surgical history would have been without it.

"Our fair city has had ere now, in her professional rank, great operators, such as Barton and Pancoast; great writers and teachers. such as Gibson and Gross; and great consultants, such as Physick and Torris, who, by their strong personalities, established the tradition of surgical practice in their day and gencration; but as consultant, teacher, and operator combined, the name of Agnew will long be spoken of as that of the height and glory of Philadelphia surgeons." 


\section{CHAPTER VIII.}

\section{Dr. Agnew's Original Work in Surgery.}

Iт has been stated that, while Dr. Agnew was a wonderful operator, clear teacher, and thorough diagnostician, he had no originality; that he devised no new instruments or operations, and that his name was not associated with any great original investigation in new surgical fields.

There is no more necessity of a surgeon inventing new instruments or new operations or pursuing original in restigations to become a great surgeon than there is in a great lawyer derising new legal procedures, or, to compare it with an occupation which approaches surgery on its manual side, for a carpenter to devise new tools or new methods of carpentry.

It is the faithful, intelligent way in which he uses the knowledge of his day in the regular routine of his life which constitutes the really valuable work in a surgeon. It is the fidelity with which the daily grinding application to work is undertaken-on which it is impossible to dilate-that forms the real basis of comparison of surgeons. It was here that Dr. Agnew stood pre-eminent; yet in a biography of his career this work can only be suggested. There is no way to show its extent without wearying the reader. The description of the invention of some trifling instrument or operation takes more room than any description of many years' work of this character in a surgeon's life.

There is more or less of a delusion in the claim of any originality in surgical work, for it is a gradual growth, to which every observer adds his quota. A surgeon may develop great pettiness of mind and spirit in derising methods or instruments just a little different from those in use already and claiming them as inventions of his own.

Dr. Agnew disdained such work; although he had that 
adiptability of making anything suit his purpose. For example: After showing complicated or expensive instruments for certain purposes, at his lectures, he would invariably say: "But, gentlemen, you do not need these things," and he would proceel to improvise, out of simpler, cheaper instruments, the necessary articles.

On the other hand, it is the purpose of this chapter to show to some extent the rariety of instruments and operations devised by Dr. Agnew, and some reports of the original investigations which he made. It must not be understood that this list comprises the cutire number of operations or instruments which 10r. Agnew devised; it is simply a sample of this work on his part. All those who are interested in this feature of his work sufficiently to pursue it further are referred to his treatise on surgery. The description of his own work in his "Surgery" is not complete. His well-known modesty impelled him instinctively to place himself in the background, and he does not claim, by any neans, all that is lis due.

Again, I)r. Agnew never blindly followed directions in any operation nor in the manufacture of instruments. Dr. Agnew probably never did two operations exactly alike; he modified every operation in each case to its own wants and needs. He always seemed to possess a great reserve fund of commonsense which fitted into the case before him exactly. He treated each calse simply on its own demands, not on the lines laid down in text-boolis.

Among the instruments devised by Dr. Agnew was his well-known anterior angular splint with the posterior angular trongh. 1)r. Agnew devised this simple instrument for supracondyloid and condyloid fractures at the elbow-joint,- - difficult conditions to treat properly.

'To prevent bleeding in case of wounds of the chest from rupture of the intercostal vessels, Dr. Agnew devised a ncedle, strong, sharply-curved, with a blunt point, having in it an eye for the thread. 'This formed a very efficient instru- 
ment for putting a ligature around the rib and ressel. He also invented another ingenious instrument for compressing the wounded intercostal vessels. This instrument cousisted of two branches,-a permanent one, having a little mortice on its concave surface, into the middle of which is fitted a short piece of sea-tangle; the other branch of the instrument is movable, and can be run up and down on the shanks by tuming a handle. The object of the little piece of sea-tangle set into the groove on the immer branch of the instrmment is, that by its swelling it may compress the vessel which lies below the common level of the rib in the costal groove.

Dr. Agnew also devised an artery-forceps, the blades of which are long and slender and armed each with a tooth, which can be made fast by a button-slide.

For the treatment of extra-capsular fractures of the humerus, Dr. Agnew devised an internal angular splint, and a cap for the shoulder and arm. By using his method the axillary wedgeshaped pad of Sir Astley Cooper is discarded.

Dr. Agnew also contrived a rectal chemise for use in dilatation of the internal and external sphincters, in operating for hemorrhoids. This rectal chemise is to be used when the surface removed is too extensive to be stopped from bleeding by the ordinary methods. This instrument, like others devised by Dr. Agnew, was extremely simple, consisting simply of the largest-sized gum catheter, through the openings at the end of which is passed a stout silk thread. Then three square pieces of ordinary mosquito-netting are taken and placed one on top of the other; at the centre of these squares or pieces an opening is made and the catheter passed through, and the two are fastened together by threads.

Dr. Agnew invented, for use in fracture of the patella or knee-cap, a simple, ingenious, and efficient splint, which talies the place of more elaborate instruments. It is the most common splint for this condition in use at present.

For the removal of the curious deformity of webbed fingers, 
1)r. Agnew originated an operation which removes satisfactorily and permanently this condition. The trouble in this deformity has been to prevent its recurrence; by ingeniously dissecting flaps and stitching them together Dr. Agnew obviated this difficulty entirely.

Dr. Agnew devised a retractor for holding aside the sac of the peritoneum during operation upon the iliac arteries. This instrument was a great convenience in ligation of the external iliac artery. Dr. Agnew also derised a spiral wire probe for use when the sinnses passing down to diseased bone were tortuous; from its flexibility such a probe could follow the winding track.

1)r. Agnew also invented a thoracic trocar and canula for use in the operation of thoracentesis. This instrument consisted of a trocal and canula with a stop-cock and a gum bag or bottle, having a nozzle at one extremity fitted to the end of the camula and at the other a stop-cock by which it can be conveniently emptied and filled. By use of this instrument the fluid can be drawn out by snction, requiring no air-pump. In the absence of the rubber bag a bullock's or hog's bladder may be cmployed as a substitute. In this Dr. Agnew shows his adiptation of the ordinary implements and instruments found in the average country household to suregical use.

Dr. Agnew originated an operation for the treatment of salivary fistula. 'This annoying, disfiguring, and obstinate discase resisted all operations intil Dr. Agnew devised an operation which was simplicity itself. It consisted in depositing a thread between the duct and the ontside of the cheek with its two ends bronght out at the corner of the mouth. As the thrcads cut their way out by ulceration the duct is detached from the external opening in the cheek.

Dr. Agnew also devised an operation for the radical cure of hernia. which he snbequently discarded.

Ir. Agnew also modified the method of reduction by manipuation of dislocations of the arm at the shoulderjoint. Dr. Agnew derised an apparatus for hip-joint disease 
which he advises for use under certain circumstances. When, on account of parental obstinacy, the surgeon is sometimes compelled to compromise by adopting a splint instead of following. other treatment, such as rest in bed, Dr. Agnew adrised the use of this splint.

Dr. Agnew also modified a number of amputations; for example, he modified the flap method (or the musculo-tegumentary method), in which, by an ingenious cutting of the flap, he was enabled to make the skin and muscles of the same length, avoiding the deformity which results from the retraction of the skin, which exists to a much greater degree than that of the muscles.

Dr. Agnew also devised a method for reducing paraphimosis, by which the methods in common practice were rendered unnecessary. It is a much more rational plan. Dr. Agnew also devised a blood-catheter, which serres the purpose very well.

Di. Agnew also devised a stone-forceps for use in lithotomy in children. Dr. Agnew also contrived a pair of long, rat-toothed forceps for use in the operation of vesico-raginal fistula. In gynecology Dr. Agnew also devised a mackerel-bill écraseur for use in dividing uterine polypi. Dr. Agnew also devised whalebone bougies of certain shapes and sizes.

In regard to the statement that Dr. Agnew possessed no specially original thoughts in surgery, because his name is not associated with many wouderful advances, this was due partly to the fact that Dr. Agnew held human life too dear to experiment on it, as must be done in all original work, and partly to the fact that he was so busily engaged that he did not have time for the research for which he was so cminently fitted. At the same time, no small amount of original investigation was done by lim.

In strictly surgical and pathological work stand his experiments made to establish the fact of the transformation of the coagulum, clot, or thrombus into an organized structure, and 
its unification with the walls of the ressel,-in other words, to defermine the method by which nature arrests hemorrhage. In order to sturly this process satisfactorily he had a number of ligations made of the arteries of dogs, by Dr. William II. Mastin, at the University Iospital. The animals were killed at different periods and carefully injected, after which he had an opportunity of studying each specimen as it was prepared by I)r. E. O. Sllakespeare.

1)r. Agnew's practical conchusions are quoted from the work on surgery, vol. i, page 216, as follows:-

. When a ligature is placed about an artery and firmly tied, the resiol is constricted and puckered up at the point of application. 'The effect of such constriction is to diride the middle and internal coats, which become both incurved and retracted, the external or fibrous coat remaining unserered. The blood thus arrested begins to coagulate first at the seat of ligation, where it orempies the cutire circumference of the canal of the rescrl. 'T'o this coagulum or thrombus are added successive layers or lamine, and as the column rises it becomes conical in form. raching up to the first collateral branch, and either not tonching the walls of the vessel or resting only anainst one of its sides. The dirertion of these suecessive additions or laminæ in the thombus is transverse or slightly oblique.

- If a portion of this internal thrombus be examined at any time after its roagulation, with a sufficient power, it will be seen to (om int of a rant crowd of red corpuscles, with here and there, indiveriminately sattered. a few white ones, and all supported in the fibrinous frame-work of the clot.

"l'ressing the investigation further, let a section of the artery and its clot be make twenty-four hours after ligature, and a wonderfin change will be noticed in the numerical relation of the two kinds of roppusedes. Firen in this short period of time the red. which had predominated so greatly have begun to disappear. and the white corpundes are now seen thickly scattered 


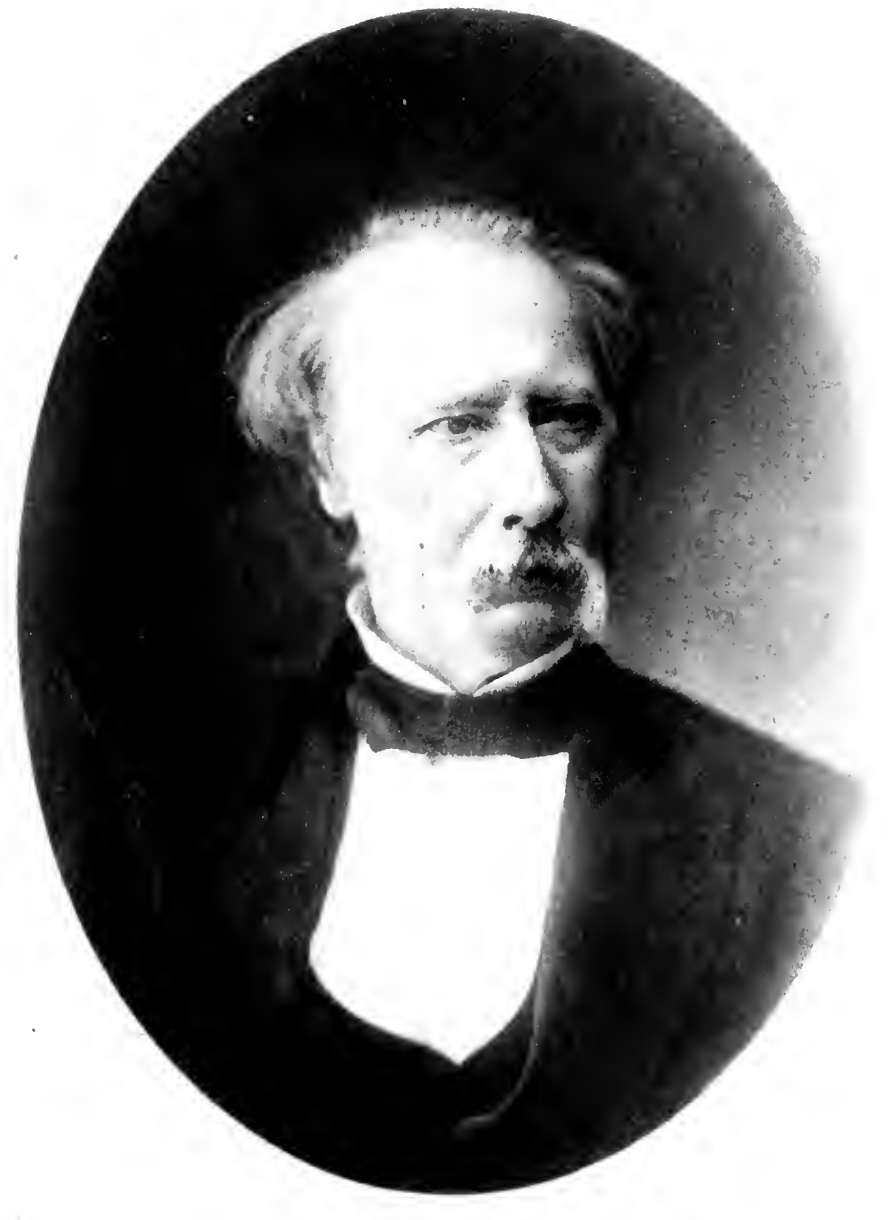

DR. AgNeW IN 1876 
$+$ 
over the field. If successive sections of this clot be made from the base towards the summit, it will be seen that the white corpuscles diminish in numbers from below mpwarts; that is, they are most numerous in the oldest part of the clot. The secure manner in which the clot or thrombus is first mechanically connected with the enclosing walls of the vessel is here wortly of observation. This connection is threefold: first, by being crowded into the corrugations made by the puckering of the vessel at the point of ligature; second, by moulding its surface into the plications of the tunica intima, or internal coat; and last, by the peculiar behavior of this coat, which. after being severed by the ligature, splits into filaments or threals, which float into the midst of the coagulating blood, and, like guys, serve to moor the clot securely into place. The questions which, at this stage of the process, demand explanation, are very difficult of solution. The are not yet in a position to answer them with any certainty, and any attempt in that dircetion brings us at once into the domain of conjecture. 'These questions are: Where do these crowds of white corpuscles come from? and, What is the destiny of the red globules? "With reference to the first, the origin of the white bodies, sereral explanations may be adranced. They may originate by proliferation from the few which naturally belong to the thrombus, as no limit can be fixed to the muidity of cell nultiplication under certain stimulation; they may be emigrants wamdering into the clot from the vasa vasorum, according to the views of Recklinghausen and Bubnoft; they may be derived from the stable cells of the tuniea intima, which accords with the opinions of Romberg and Thiersch ; and last, and least probable. they may be but a retrograde metamorphosis of the red corpuscles, on the supposition that the red are drecloped from the white corpuscles. I camnot, however, help beliering that these cells are derived from three sourecs: first, from the proliferating white corpuscles of the clot; sccomel, fiom the fixed corpuscles of the endothelium; and last, from the emigrants from the rasa 
riacorum. It is quite as probable that the endothelial cells should participate in the work of repair; in other words, change from a passive to an active state, as that those of connective tisisue should do so muder the disturbing influence of inflammation. Those experiments which show the presence of cells in new formations bearing granules of cinnabar previously injected into the blood would seem to establish a claim for emigration.

"This last view is not in accord with that of Billroth, who denies to the stable cells of the intima any participation in the work whatever, attributing multiplication of white corpuscles to the lencorytes of the clot and to wanderers from the neighboring ressel. coincirling in this respect with the statements of Recklinghansen and Bubnoff. As to the red corpuseles, they very soon become derolorized by the separation of crystals of hæmatoidin. and, it is supposed by some, form an intercellular substince by uniting with the fibrin of the thrombus. If the thrombus be examined on the fifth day, another notable change will be seen. Many of the cells have become spindle-shaped, one step in the direction of forming comnective tissue; others have sent out prolongations, which, joining with similar procesces from contiguous colls. form together a net-work with rery distince mudei at the points of contact or communication. In this sytem of inosculating processes we have the provision for the vascularization of the thrombus. 'These processes become blootletamuels. and, although as yet containing no blood, they are, like the irrigating anals which are cut in various directions through some arid waste, designed to receive the streams which ale to give life and fromitage.

- While tluse changes are in operation within the thrombus the walls of the vessel are by no means passive. An active inflammatory transuclation is going on, infiltrating its tunics and extending even into the loose cellular tissue of the adventitions conts. It is this which rives asmder the fibres, lamella, and firscirnli of the arterial tunies, and admits of their being interpenetrated by cell organisms or leucocytes, which wander out 
of the nutrient vessel, and which, like those of the clot within, assume the spindle forms, which are the promise of the finture connective tissuc. In the course of eight days the work foreshadowed in the thrombus of fire days is well adranced. Many of the blood-chamnels are completed and others are in process of completion, the processes of the latter connecting with the nuclei on the walls of the former; the spindle form of the cells, both of the clot and walls, is more pronounced, and near to the intima they have reached the stage of immature connective tissue. The clot is beginning to shrink from loss of moisture in the intercellular substance, the whole becoming more compact.

"In all these changes or stages of transformation it would appear that the constructive foree develops ont of the materials of the original clot an organized tissne,- that is to say, the white cells of the thrombus retain their vitality and undergo multiplication, passing on to the spindle form; that the fibrin which determines the coagulation is not substituted by something else, but transformed into intercellular material, the fibrillation of which, with the spindle cells, constitutes true connective tissue; and, finally, that from other cells a system of inosculating canals is constructed, thus forming a vascularized structure. Thus far we have traced the leading changes in the clot toward organization. "We have seen the infiltration of the tmies of the ressel with cell forms similar to those in the coaguhnm, and their intermingling at the tunica intima, obliterating in some degre their distinction from the latter. It still remains to establish a very important vital comection between the two, and that is the connection or inosculation of blood-ressels. 'The thrombus is in possession of a system of calpillaries. but they contain no blood; and the next step is to form such a union with the ressed of the artery as will establish not only a mity of blool-channels, but also a oncuess of circulation. 'l'o acromplish this it would appear, from certain preparations recently made by I r. Shakespeare illustrative of this point, and which I had the opportunity of examining, that in this inosculation between the 
vescels of the thrombus and those of the walls the former take the initiative, penetrating the tunica intima, first, near to the point where the artery has sustained the greatest injury by the action of the ligature."

Dr. Agnew also performed a number of experiments to determine the process by which callus is converted into true bone. It is a fair sample of the style of investigation he pursued :-

"The development of the organizable material of the callus into true bone will be best illustrated by introducing, at this point. the results of a number of experiments which I made upon the bones of chickens, dogs, and guinea-pigs. For this purpose numerons fractures were produced, and dissections, followed by microscopic examinations, made at various periods from an hour and a half after the injury until the twenty-fifth day.

"These fractures were all simple. It has been stated that after surh an injury the blood finds its way into the medullary canal between the fragments, allueres to the edges of the periostemm when torn, and permeates the muscular and the connective tisure next to the bone. This describes most accurately the appearance presented in the first dissection I made one hour and three-quaters after the injury. I second dissection was mate three days later. After remoring the skin and fascia, the seat of damage was recognized by a swelling over the break, of a perulial. spindle-shaped form. Even the tendons were curion-ly spread out into a ribbon-like expansion. and quite adherent to the parte mulemeath. On the fifth day this enlargement is probably at its height, and at this time a specimen was divided lompitudinally, for the purpose of study. The periosteum was separaterl for orer half an inch above and below the seat of fracture. It the latter point the separation was greatest, becoming less above and below; hence the spindle form of the cnlarement. To the maided rision the same material which lay beneath the membrane was also external to it, so that the 
periosteum was in reality embedled in or incorporated with it. It was also seen between the ends of the bone when not displaced, or betwcen the contiguous surfaces when overlapping, and, finally, for some distance up and down the medullary canal. This preliminary formation was a light-colored, consistent sul)stance, interspersed with dark-red spots, and gave to the fracture a considerable degree of fixation.

"This specimen was placed, for microscopic preparation, in charge of Dr. Rhoads, who furnished me with an opportunity to study cach section, in order that the appearances might be more vividly impressed upon my mind. The material in contact with the fracture was found to consist of blood-corpuscles in rarious stages of disintegration, some adhering in rolls and preserving, in some degree, their form, some isolated, others collapsed, with irregular or stellated margins, homogeneous lymph, and great numbers of the so-called germinal corpuscles. or, in the light of more recent discovery, lencocytes. These components were irregularly intermixed, and here and there stained with what seemed to be the coloring matter of broken-down blood-corpuscles. The lencocytes raried much in form; some were round, others oval. They varied also in size, as though under the active process of change.

"In the compact portion of the bone a noticeable contrast existed between the Haversian canals near the fratured ends and those more remote. The size of the former was much greater, and they presented at 11 momeroms points little recesses or loculi leading off from their sides. The blood-resiols could be distinctly seen, but they were puned off from the sides of their bony canals, the intermediate spare being orcupied by crowds of cells in all respects like those exterior to the bone. and which came, no donbt, from the Ifaversian resuch. Xow, as the Haversian canals open into the medullary space, and also mon the broken surfaces of the bone, the conchusion was incritable that many of the cell-bodies seen in the medullary canal came from these sources, as well as from the vessels of the medullary 
membrane. In this rapid enlargement of the hard bony canals traversed by the blook-ressels we have an example of one of those singular changes which attend inflammation, and which it is difficult to explain. That it is due to absorption from the presilue exerted by the exudation is exceedingly improbable, as such pressure would destroy the contained ressels rather than affect the bony walls with which they are surrounded.

"In studying the inflammatory process in other tissues, an analogoni phenomenon may be witnessed. In cartilage, for example, the normal corpuscles which lie embedded in the intermediate substance have their places oceupied by a multitule of lencocytes, more changeable and active than those which they have repliced, and whose insatiate demand for pabulum compels them to prey upon the matrix, the consumption of which gives the structure an open, reticulated, or honeycombed appenance. It is quite probable, therefore, that the organic constituents of bone may be attacked by the migrated cells of its ressels, and, thus separated from the bone-salts, give rive to the enlarged canals and their irregularities. The phenomena presented in this first specimen appear, then, to have been those of an inflimmatory character, in which all parts of the bone at and contiguons to the fracture were engaged. The priostem incorporated with the reconstructive material in wren or cight days entirely disappeared as such, molergoing those changes which inflammation produces in ordinary connectire timene, while a new membrane was produced external to the -pindle-hatped mass of new matter and continnous with the old periontem at the limits of the separation.

" I second specimen, nine days old, was subjected to a similar examination. In this fracture the periosteum had not bern contirely brokens and conequently there was no displacemont of the fiagments. It was divided longitudinally. The periontrum wan not torn from the bone, but was separated by the cxulation for about one inch above and below, in the same fusiform or spindle-like manuer as in the specimen first studied, 
only to a greater degree. The reconstructive material lay between the bone and the periosteum, external to the latter, between the ends of the fracture in small amount, and within the medullary canal. This does not accord with Mr. Stmuley's statement, who alleges that when thus apposed, and without disturbance, no provisional callus is supplied by nature. but that immediate union takes place,-an opinion in which. I believe, Mr. Paget concurs. The stage of organization was not alike in all portions of the new material. The development was evidently advancing from without inwards. The greater part of this new formation consisted of round, oval, and elongated masses of germinal matter, surrounded by a faintly gramular and fibrillated intercellular or formed material.

"These cells were grouped irregularly, or arranged in an orderly manner in concentric ranks, corresponding to the canals seen a little later and foreshadowing the limine of the Haversian systems. The cells which lay between the ends of the bone and in the medullary canal were more numerous and less distinctly altered from the globular form, and were greatly in excess of the intercellular or formed material; this latter was still mingled with a little broken-down blood. In the angles between the periosteum and the bone, and in an oval space near the centre of the external or ensheathing matter: the transformation into soft bone had taken place by the deposit of bone-salts. In these situations the Harersim callats were lange and numerous, rumning, some diagonally, other's perpendicularly, between the periosteum and the old bone. Simnltancons with the calcareons conversion of the intercellular material were the formation of the canalienli and the shaping of the previonslyarranged cells into distinct lacune.

"In the spindle-shaped curclope or fermle we larse the ensheathing callus of Dupuytren, or what he termed "provisional callus, while the portion occupying the canal answers to the pin. These, according to this distinguished surgeon, were only temporary in their duration,- - splints, in other words, to main- 
tain a degree of connection until a sccondary deposit took place between the ends of the bone, after which the former were removed, being no longer of use.

-Other specimens were examined on the thirteenth and seventecnth days. These exhibited a more adranced stage of ossification, though in some places many cells were seen which were not cartilage cells. Between the broken ends the intercellular substance had increased, and some progress had been made in its conversion into bone, permitting much less movement at the break. At other portions of the callus canaliculi were forming in the intercelhular material, and which evidently commenced on that part of the callus most remote from the lacunce. The entire mass of new bone was a trifle more open and pong in its texture and of a slight rosy tint. Anxious to determine the vascularity of the reconstructing substance, on the fifth day after making a fracture of the wing of a chicken a delicate pipe was inserted into the brachial artery, through which 1 injected some ultramarine suspended in glycerin. A section was made of the bone and submitted to Dr. Rhoads for examination. Although the injection was not so satisfactorily done as I conld have wished, yot the coloring matter had filled numerous vesols throughout the callus. These vessels in the extemal rallus ran for the most part perpendicularly down, the callus osifying aromend them.

" liwo additional specimens. one twenty-one and the other twonty-thre disys old. were carefully studied. 'The appearances presented were cutirely in harmony with the previous speeimens. The cutine reconstructing milterial had been converted into bone, so that scalcely a trace of cartilage could be seen. The amount of exterior callus hat diminisled and become more compact, and that between the ends of the bone, though much less perfently tran-formed into oxeous tisne by the deposit of the bonesalt in the interecllular substance than other portions, had nevertheden makde material progress.

- Mcescher and Votsch state that ossification in birds is 
always in cartilage; Wagner states virtually the same in the case of rabbits, and in all the cases which furnished the subjects of the present experiments the same fact wis observed. It is asserted that in man the repair or ossification may take place either in cartilage or in fibrous or fibro-cartilaginous tissue.

"This statement needs confirmation. At the time l was engaged in these experiments a patient was admitted into the Pennsylvania Hospital who had broken his femur in the lower third in the act of pulling off his boot. Six weeks later the man died, and I had the opportunity of examining the bone. 'Though the fractured limb had been kept perfectly quiet, the appearance presented was identical with that of the bones which I had under experiment. There was the same spindle-shaped swelling on the exterior of the bone, extending for two inches above and below the fracture, and most of which had been conrerted into bone, while in that portion between the ends, and where the process was less adranced, lay cartilage-cells in a ritreonslike matrix, but not a trace of connective or fibrous tissue.

"Of course, it would be unsafe to speali dogmatically from a single example, but it is sufficient to excite a doubt as to union save through cartilage tissue. It is certainly true that the amount of peripheral callus is greatly influenced both by the relation of the fingments to cach othere and by the degree of disturbance to which they are subjected. becoming exuberant when there is overlapping, and cipecially so when the? ends are not sufficiently immobilized; but i think that any one who will study the fiacture specimens in our museums will be convinced that in all long bones, whaterer mat be the age of the specimen, there is manifent evidence of an ensheathing callus, increasing somewhat the rolume of the bone at the seat of injury. The conchunions which I think are rendered probable by these and other observations are the following :-

"First. That there is no cridence founded on structure that the process of healing in the fiactures of man may not be 
studied by experiments on the lower animals, or that the repair in the latter materially differs from that in the former.

"Secomel. That the reparative act is the result of inflammaltory process.

-Third. That the reparative material is furnished by the ressels of the periosteum, endosteum, and bone, and, to some extent. by those of the adjacent soft parts.

"Fuith. That the uniting material is deposited external to the bone. constituting an ensheathing callus; also in the medullary canal when there is no displacement, and between the ends of the bones; that the conversion of this preliminary substince in to bone proceeds from the surface towards the centre, so that the exterior is hard long before the interior, which will aecount for the morement discorerable in specimens apparently solidly minited together.

* Fifth. That the union of bone is through cartilage, and even through cells which have not reached the typical form of cartilase, and in this respect does not materially differ from the process observed in the primary development of bone.

" Sirth. That the presence of the ensheathing and medullargralhus, thought to be exceptional in man, should be considered the rule.

- Seventh. That the terms temporary and provisional callus. as uned by Dupuytren in contradistinction to the definitive. must be aceepted with considerable limitation, the one not diffuring in any particular of composition from the other; that the delay in the production and bony transformation of the intermediate or defintive callus. as compared with the exterior and interion portions, is due only to the comparatively small rascularity of the compact part of the bone.

- Eighth. Thiat the complete absorption of the ensheathing callus nerer ocenss, and that the re-absorption of the medullary callus is not a work of nature set in operation because the union at the ands of the bone has become complete, but is simply a repetition of the orter followed in the development of the long 
bones, entirely independent of the fracture,-a work which contributes both to their lightness and to their mechanical strength. "The time involved in the whole work of restoration varies, no doubt, in different persons, and is affected by various circumstances, such as the health of the patient. the quiet of the parts, and the accuracy of the adjustment. The process in its entirety may be described as follows:-

"First, there is a period of rest.-one in which there is no visible attempt made to repair the damage. All seems quiet. Everything within the area of injury remains in chatic confusion; and as an architect, before he begins the work of reconstruction, quietly surveys the mass of ruins of some noble building which has gone down under a sudden catastrophe, so the genetic forces of the parts secm to broor silently. for a time. over the scene of disorder before any note of preparation is souncled. This is of short duration, not generally extending beyond thirtysix hours. Following this comes a reactionary period. in which the ordinary phenomena of inflammation are present. There is an increased determination of blood to the part. acempanied by a transudation. This is sometimes very considerable, giving rise to much swelling and an exalted sensibility of the parts, and may continue for three or four dars; so that the first five or six days are consumed in passing orer the stages of local shock and inflammatory disturbance. It camnot be satid that during this time any true reconstructive work lans been iningurated.

"In this respect the repair of fractures in lower animals. as chickens, rabbits, etc., differs from that in man. In the former the process of mion is well established in seven or eight dars. The acute symptoms haring sulsided. another period of three or four days elapses, during which a part of the inflammatory products and a portion of the extravisated hlood and other débris consequent upon the injury are removed, and the tenderness and swelling, as well as the irritalility of the surrounding muscles, become diminished. The vasulatity. howerer, of the bone, periosteum, and endosteum does not diminish, but rather 
inercases. From the eighth to the tenth day the real work of repair begins, that in which the true fibrogenous matter, swarming with cellular elements, assumes the appearance of order.

"- The differentiation of this constructive material into cartilage or fibro-cartilage and intercellular substance, and the subsequent deposition of the bone-salts, ultimately permeating the mass and imparting solidity to the bone, are the work of four or five weeks.

" Now, while we have divided this process into stages, allotting to cach an approximate number of days or of weeks, it must not be supposed that these gradations are sharply defined, and that one camnot begin until the other is ended; on the contrary, they may blend or co-exist, and can only be regarded as appoximately true; but they are, nevertheless, conrenient for purposes of description.

"In children, mion will often occur with great rapidity; and I lave even known an adult with a fracture of the femur to rise from his bed and walk at the expiration of four weeks; indeed, I am convined that the healing of factures takes place at an earlier period than is gencrally believed.

"Such is the ordinary mode of repair. It is alleged by some that where the apposition is very perfect, as where the frisgments rest end to end or edge to edge, or where there is an incomplete separation of the fibres of the bone, immediate minom may talke plare, just as it is alleged to oecur under farorable circumstances in the soft parts. I lave never seen any sperimen whirle would indure me to adopt sueh a conclusion.

- In compond frartures the existence of an externat womel and thr smplumation which ensues modify the plan of restoration. The work is reatly delayed, and the union is efferted though a larger amonnt of granulation than in simple fractures, which, after its transformation into fibro-cartilaginous tissurs. becomes incorporated with the lime deposits. In other words. the difference between the healing of simple and that of 
compound fractures is much like that between the healing of subcutaneous and that of open wounds.

"In compound comminuted fiactures the healing is still longer delayed. Detached portions of the bone die from losing their connection with the periosteum and the modullary tissne, and from the influence of the inflammatory produrts. The work of reparation is delayed until the sequestra are got rid of, after which granulations spring up abundantly from the medullary and periosteal tissues and undergo ossification. The time required for the separation of such necrosed portions may be so great that the restorative powers entirely fail, and no mion will talie place; or, if united, the connection is cstablished in a large sheath of irregular callus, without any cohesion of the ends of the fragments to each other. It is in such fractures that we often find the hard and the soft parts extensively glued together by inflammatory lymph. Where there is loss of bone, in most cases there will be shortening, particularly in the adult; although, as shown by M. Ollier, the preservation of the periosteum will often provide, to some extent, against this, by supplying the material for partially bridging the wap.

"When a cartilage is broken, the perichondrim behares like the periosteum, furnishing the material for a hond of union, which consists not of cartilage, but of bone, and which envelops the parts like a firm ring. lnt often not filling the intermediate space, or that between the cuds of the framments. An epiphysis, when detached from its diaphysis, although the original conjunction was one of cartilage, will afterwards unite by bone; and as the bones grow in length by a deposit in the cartilage which exists between the ends of the shaft and the epiphyses, it has been stated that in such fractures the bone ceases to grow in the longitudinal direction. I have reason to doubt the correctness of this statement, believing that, although no increase in length may take place at the injured part, the failure is compensated for by increased activity in the nutrition of the intermediate cartilage at the other extremity. Fractures 
which extend through the articular incrusting cartilage seem to have no power to unite. There are other fractures which do not unite by callus. They are such as are subjected to the influence of the synorial fluid, or whose vascular supply is insufficient. Among these are fractures of the neck of the femur within the capsular ligament, of the head of the humerus, of the olecranon process of the ulna, and of the acromion process of the scapula. Fractures of the patella generally come under the same category." 


\section{CHAPTER IX.}

\section{Dr. Agnew as a Writer.}

As has been said, Dr. Agnew was not a prolific writer; his articles were numerous, but not in comparison to the lists of many of his colleagues and the length of his life; they were always in response to some well-defined demand.

The following is the list of the books and articles published by I)r. Agnew. The majority of these are reports of his clinical lectures written not by himself, but by medical reporters :-

The List of the Books, Articles, and Addresses Published by Dr. Agnew.

1856. Practical Anatomy; a New Arrangement of the London Dissector. 2 d edition, 1867.

Valedictory Address, Pliladelphia School of Anatomy.

1857. Valedictory Adrress, Philadelphia School of Anatomy.

Theatrical Amusements.

1858. Valedictory Address. Philadelphia School of Anatomy.

1859. Introductory Address. Philadelphia Selhool of A natomy.

Valedictory Adrress. Pliladelphia School of Anatomy.

Obituary Notice on Frederick S. Geiger, M.D.

1859-64. Sixty articles: "Anatomy in its Relations to Medicine and Surgery." Medical and surgical lieporter.

1859-i1. Clinieal Reports. Medical and suregical lieporter.

1860. Faledictory Adrress, Philadelphia school of Amatumy.

Introdnetory Address, "Classification of the Animal Kingdom."

1861. Address, "Baron Larrey."

1862. History of the Philutelphia Almshouse IIospital. Reprinted in

Philadelphia IIospital Reports, 1890, vol. i, p. 1.

1865. Lacerations of the Female Perinemm.

1867. Tesico-Taginal Fistula.

1870. Introdnctory Lecture, University of Pemnaylrania.

1875. President's Adress, Philadelphia County Medical Society.

1876. "Address on Surgery," I'emnylrania State Medical Suciety.

1877. "Iydrocele." G. P'. Putnan \& Sons. 
1878. "Attitnde :mr Expression in the Dianosis of Surgieal Diseases." New York Hedical Perord, vol. xir, ply. 424-26.

" Errors of Diannosis." President's Address, Pennsylrania State Medical society.

Principles and P'ractice of Surgery rol. i, 21 edition, 1989.

1879. "Popliteal Anemisu." Hospital Gazette, vol. vi. p. 387.

Biographical sietch of Dr. Juln Rhea Barton. Delivered at the Acarlemy of Music, at the ammal Commencement of the Medieal lopartment.

"I'istol-shot Wound of the Hand." Hospital Gazette, vol. vi, p. 369.

"Nerns." Cincimati Lancet-Clinic, n. s., rol. iii, p. 434.

1880. "Anchylosis of the Elbow-Joint Following Dislocation, in a Indico-Legal Aspect." Boston Medical and Surgical Journal, vol. ciii. 1) 33.

1ss1. "General l'rinciples of Surgical Diagnosis." International Encyclopedia of Surgery, vol. i, p. 397.

"Treatment of Tesical Catarla by Establishing Urinary Fistulæ." Ihiladplyhia Medical Times, vol. xi. p. 300.

"Trammatic 'Tetanus." Medical and Surgical Reporter, Philadelphis, rol. xlis, p. 654.

"Popliteal Anemism; Cure by Ligation." Medical and Surgical fiepreter, l'hiladelphia, vol. xly, p. 151-2.

"Clinical Renarks on Lithotomy in Children and its Complieations." Jew Fork Medical Pipenred, vol. xx, 1) 681.

Principles and Practice of Surgery, vol. ii.

1852. Iaceration of the Femble Perinemm and Tesico-Taginal Fistula.

"Ah-tlact of" a Clinical Lecture on the Recognition of the Early Stages of I'utt - Discatice." Merlical Neus, vol. xl, p. 4.

"Clinicall Lecotme an Stone in the Bladder." Virginia Medical Homthly, Richlmond, vol..ix, p. 12.

"A Case of Clumie Cystitis." Melieal Pecord, vol. xxii, p. 92.

"Cumnitor Froncture of the Teek of the Femur." Medical and

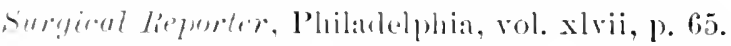

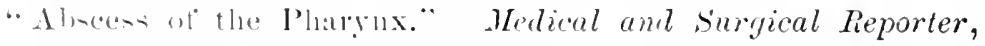
P'hilateluhia, rol. xhii, l. fis.

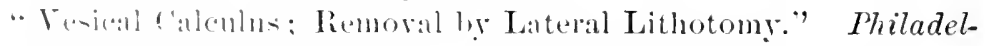

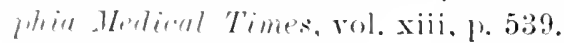

1833. "T'manatic L'Pualy Fistula ; Exterual Perineal Urethrotomy."

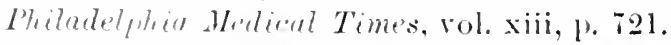

"Xecroris of the Tibia." Philadeiphia Hedical Times, vol. xiii, 1) 791. 
1883. "Osteotomy upon the Left Superior Maxilla for the Removal of Post-nasal Fibrous Polypus." ILedical News, vol. xliii, p. 141. Principles and Practice of Surgery, vol. iii.

1885. "Note on the Use of Salvia Othicinalis in Catarthal Rhinitis." Therapeutic Gazette, 3, s. 1, p. 17.

Nemoir of Elias R. Beadle, D.D.

Valedictory Address, Commencement of Medical Department.

1886. "Painful Muscular Spasm Treated by Excision of Portion of the Nerve-Trunk." Medical Times, vol. xvi, p. 279.

"Memoir of John Light Atlee." Transactions of the College of Physicians.

1887. "Nephrorrhaphy and Nephrectomy." Medical Neus, vol. I, p. 116. "Excision of the Larynx and Pharynx." Medical Ner's, vol. I. p. 401.

"Medico-Legal Aspect of Cranial and Heart Wounds." Transactions of the American Surgical Association; also, Hedical News, vol. 1. p. 561 .

"Nephro-lithotomy." Medical News, vol. 1, p. 682.

"A Death During and a Death Before the Administration of Ether." Medical News, vol. li, p. 589.

1888. "Nephro-lithotomy." Medical News, vol. lii, 1. 115.

"The Relation of Social Life to Surgical Disease." Transactions of the American Surgical Association; Hedical News, Philadelphia, vol. liii, p. 316.

"Laparotomy with Excision of a Portion of the Ilemm." Medical and Surgical Reporter, vol. lix, 1. 321.

"Practical Observations on Senile Hypertrophy of the Prostate Gland." Cniversity Medical Magazine, vol. i, p. 1.

1889. "Tracheotomy." University Medical Magazine, rol i, p. 519.

"The Choice of Operations for Vesical Calculus." C'nicersity Medical Magazine, vol. ii, p. 1.

"The Radical Treatment of Hernia." Lniversity Medical Magazine, vol. ii, p. 339.

Address, Opening Exercises at the IIonse of hefinge.

1889-91. President's Addresses. Transactions of the College of Physicians.

1890. "Injuries to the Peroneus Longus Temlon and its Sheath." University Medical Magazine, vol. iii, p. 1.

1891. "Pancreatic Cyst. Removal hy Laparotomy" Recovery." University Medical Magazine, vol. iii, p. 469.

"Fistula of the Duct of Steno." University Medical Magazine, vol. iii, p. 583. 
1891. "The Present Status in Brain Surgery Based on the Practice of Philalelphia Surgeons." University Medical Magazine, vol. iv, 1. 17.

1)r. Agnew conld wield a pen exhibiting, to a marked degree, sarcastic retort, combined with humorous comparisons; for eximple, in talking of religions subjects he said, in regard to certain persons, that "their minds are first made up to a judgment, and then the Bible is subpenaed for its defense. questioned and cross-questioned, threatened and coaxed, put upon the rack of criticism and interpolation, a sentence seized upon here and another there, and these are all marshalled in to line, contrary to every rule of grammar and logical interpretation, until an opinion is formed wreaking with the blood of violence. It is not 'Speak, Lord, for thy servant heareth,' with these people, but - Hear, Lord, for thy servant speaketh.'"

There was a picturesqueness about his style which gives a dash to all of his productions, however dry their character. For example, in speaking on a political subject, he said: "The heart of the old Whig party throbbed its last pulsations with the death of Ienry Clay, and the American organization known by the solviquet of 'Know-Nothing,' which came forth with the growth of a fungus in a night, like Jonah's gourd, has passed away as the moming-dew, leaving the shillalah and shamrock as invincible as ever."

In spealing of certain members of the Board of Guardians, he salid: "They clung tò office like bamacles to a ship's bottom.'

In the carly part of this hiography a valedictory address, delirered by J)r. Ignew at the Sclool of Anatomy, was given, which casts interesting side-lights on I)r. Agnew's thoughts, alucation, and beliefs of that day; in Chapter VIII are given two cxamples of his style of pursuing strictly scientific investigations; later in the work will be given his last didactic lecture. 'Threre remain yet two phases of his career as a writer untouched. One is his manner of preparing an ordinary medical essay; the 
other, his expression of his beliefs on the relations between his profession and ordinary daily life.

They are all easy reading, for Dr. Agnew alwars used the simplest, most direct words and statements in dealing with any subject. Two of them are given here, as a sample of his work; the first paper shows his clearness of thought and argument in dealing with a difficult medical question which has become a knotty legal problem; while the other paper is on the interesting subject of the "Relation of Social Life to Surgical Disease." Both were read before the American Surgical Association and published in The Medical Neus of Philadelphia.

These papers require no explanation, while they throw incidentally more side-lights on Dr. Agnew's nature, life, and character than would many pages of description :-

MEDICO-LEGAL ASPECTS OF CRANIAL AND HEART WOUNDS.

An Address Delivered before the American Surgical Association.

Is it possible for an individual, with suicidal intent, and in quick succession, to inflict a perforating shot womnd of the head and another of the chest implicating the heart? Or, reversing the proposition, is it incredible that a person, bent on selfdestruction, can, with his own hand, shoot himself in the heart and in the head?

These questions have a medico-legal bearing of no small import, and have been suggested as the subject of the present paper by a murder committed, during the spring of 1886 , in the town of Newport, Rhode Island.

A colored man, long a resident of Newport, well known both to the permanent inhabitants of and to many of the transient visitors to this place of fashionable resort, was found, one morning in his house, dead under the breakfast-table, having in his mouth some food unswallowed, and with a bullet wound in his head and another in his chest. A coroner's jury, after hold- 
ing an inquest, brought in a rerdict of suicide, and the body, under this finding. was interred.

Some recks later, through the suggestion, I believe, of one of the local phrsicians, that it was impossible for the deceased to have inflicted these clouble wounds with his own hands, both involving rital organs, the authorities ordered the body to be disinterred and the inquest to be reviewed. The antopsy rerealed a perforating shot wound of the skull, the pistol-ball (22-calibre) having entered the right parietal bone, about two inches ahove and anterior to the ear, making a clear-cut perforation of the skull and lodging in the posterior part of the left half of the cerchrum, having passed from left to right and from before bareliward.

Another ball had penetrated the thorax at a point three inches to the right of the left nipple and two inches to the left of the median line. " The ball," as was stated, "was found to have pisied through the left rentricle of the heart, entering the bas and emeroing at the apex." It is probable that the exact point at which the ball entered the chest was not accurately noterl. as it would have been an anatomical impossibility for the misile. (ntering the thorax at the position stated, to have traversed the heart firm base to apes, the base of the organ being on a level with the second costal cartilage.

'The finding of the coroner's jury, hased on the evidence developer by this second examination, was * murler by some pervon or persons mknown." Sinspicion now fell upon the sonin-law of the dead man, who lived at home with his fatherin-liaw.

This rolned man. named Dorsey, was a graduate of Lincohn Lniversty and had attended two comrses of instruction in the Meilical Department of the [niversity of Pemsylvania. II was immediately arrested, imprisoned. and held to answer for the murler. He stoutly denied any participation in or knowledere of the erime. and as the young man had, both during his stulent life at Lincoln University and at the Medical 
Department of the University of Pennsylvania. bome a remarkably excellent character, and as no possible or sufficient motive at the time could be divined for such an act, many of his friends were disposed to regard him as imocent. These convictions were strengthened by the rumor that Burton, the murdered man, was hopelessly embarrassed financially and had. I understand, on the very morning of his death, a note at maturity, without the means to cancel it.

At the trial of Dorsey, the prisoner, five medical experts were examined on behalf of the prosecution. One witness testified that either wound must have caused nearly instant death ; or, if the brain received the first ball, such a degree of unconsciousness would have ensued as to incapacitate the rictim for inflicting the second wound.

A second witness declared that the wounds were entirely inconsistent with the idea of suicide. The three remaining witnesses testified that if not more than one minute clinpsed between the shots, the ase was one of homicide and not suicide. Such were the answers as given to me by the prosecuting attorney in the case. Entertaining a different view from that expressed by the medical experts, Dr. William Hunt, one of the surgeons of the Pennsylvania Hospital, and myself, at the urgent solicitation of the friends of the prisoner, went to Newport on the last day of the trial. We arrived at the place in the night, expecting to go on the witness-stand the following morning; but, in the meantime. the trial was brought to a sudden termination by the confession of the prisoncr's wife. in which both her husband and herself were implicated in the murder. And now the question recurs,-are such wounds as those described inconsistent with the idea of suicide?

If the testimony given by the medical experts in the case just detailed is to pass unchallenged, then it follows that an innocent person, arrested and trical for mureler in a case where a shot wound of the head and of the heart existed, might be condemned to death, even though the other evidence did not raise 
the comnection of the prisoner with the deed above a mere possibility. In examining this question, I shall assume that it is posible for a shot womnd of the head and of the heart to be suicidal; and as to the precedence of injury, - the head or the heart, -it is not essential to the case.

First. howerer, let us consider the subject in the order of a shot wound of the head and of the heart. There are two conditions which would disqualify an individual bent on selfdestruction from inflicting the second wound in the chest, namely. the snepension or loss of consciousness and paralysis, partial or complete, of one or both upper extremities. The loss of conscromsness, in a given shot wound of the brain, is not due to the mere passage of the missile through cerebral matter. Tou can thrust u finger, a trocar, or a knife into portions of the brain, without affecting either sensibility or consciousness. Ioss of conscionsness is due generally either to fragments of bone carried before the ruhnerating body and buried in the cerebum. to some lare ressel or sinus being open, causing profure hemorrhage, or to transmitted vibrations resulting from the impact of a ball against the skull, thus causing a molecular disturbance of its contents and momentarily deranging the orderly operation of the intellect.

indeed. I believe that the sudden suspension of consciousnese in minly of these shot injuries of the head is che more to this conteret of the missile with the cranial wall than to its paritge through the brain. It is common to see a person fall to lis lineren ol prome upon the ground when struck upon the leanl by a proble or fragment of a stone; in an instant he is aterin on his fect. The fill does not necessarily imply loss of comacomeness, though it does mean an interruption to muscular co-ordination.

Every sureon an recall instances of the most dreadful injury to the skull and hrain without destroying the conscious rolitions of the pationt. 1)uring 1855 T)r. William Hunt and myerff were called to sere a man who had been run over by a 
street-railway sweeper during the night. IIe was seen to arise immediately after the accident and walk to his house, on spruce Street, two squares from the scene of injury. Opening the door with his dead-latch key, he passed up-stairs to his room. on the second story, and went to bed. 'The family in the morning found him unconscions. On examination, portions of the parietal and temporal bones were found driven deeply into the brain.

A prominent physician of Philadelphia was run over by an unmanageable horse, and dashed against the coner of an iron pillar, causing a frightful comminuted and depressed fracture of the frontal bone, tearing the membranes of the hrain and injuring its substance. I applied the trephine in two places and removed twenty-seven picces of bone, and yet, although unable to stand, neither mobility nor conscionsness was destroyed, for the patient gave intelligent instructions in reference to being carried to his home.

I recall another case of still more extensive damage to the skull ; one in which, by the bursting of a fly-whecl, quite onehalf of the frontal bone was carried away, and with it a considerable portion of the prefrontal lobes of the cerchrum. Only for a few moments was the man dazed; he ultimatcly made a good recovery.

The famous case occurring in the practice of Dr. Intow, and figured in some of the books on surerery is another one in point. A bar of iron, having entered the face below the zygoma, passed throngh the skull and the hain, emeroing nean the vertex, without destroying conscionsmess. A private ("Surgical History of the War," part i) named Solomon, (ompany (i, New Jersey Volunteers, received a shot wound at the biattle of Bull Run. The ball entered the skull below the tip of the left ear; the man fell, but retained his senses. The surgeon passed a probe two inches into the brain in the track of the ball.

In a letter, received recently from Sir William Mare Cormac, of London, the writer says that he thinks it entirely within the bounds of possibility for an individual with suicidal intent to 
shoot himself in the head and in the heart, or in the heart and afterward in the head, and firnishes the following cases, which render such a statement entircly possible: The first was that of a suicidal case, under the care of Mr. Hulke, where the ball traversed the head from temple to temple, but did not emerge. The patient lived fourteen days, but did not lose his consciousness until a short time before his death: he was fully able to inflict any other wound had he been so disposed. In a second case, under the care of Dr. Smith, a bullet traversed the skull from temple to temple; the patient not only preserved his consciousness, but finally recorered.

A soldier at the Battle of Pultuska, in Poland, as related by Hennen, received a remarkable wound of the brain. A ball carried away the bayonet of a musket, which entered the right temple of the man two inches above the orbit, and, passing hackward and downward, emerged through the maxillary sinus of the left or opposite side. 'The soldier, aided by two comrades, tried in rain to withdraw the weapon. The surgeonmajor, M. Forlcaur. mide a similar attempt and failed, when at length the task was acromplished by a strong soldier placing the man's head upon the ground and his foot upon the head and making traction "yon the missile. The patient ultimately recovered. and as it is distinctly stated that he joined his own efforts with those of his fellow-soldiers in their attempts at extraction, it follows that neither conscionsness nor motility wals lost.

The sccond disqualifying condition for inflicting another womml after one in the head is paralysis.

The very great adrance made in the last few years in reseirl to the finctions of the brain and the topographical relatinks existing between the exterior of the cranium and definite cerobral convolutions cuables us to locate with considerable aremaley intrit-cranial lesions from the symptomatic phenomena which may be present. The locil areas or centres of muscular power have, for the most part, been clearly established. 
It will, I think, be conceded that, so long as the middle portion of the ascending frontal and corresponding portion of the ascending parietal convolutions remain uninjured, the power to use the arms is retained. The motor contres are all grouped about the fissure of Rolando, and, unless a shot or other missile trenches on these special regions, motility remains; althongh it may, after a time, be lost by the extension of hemorrhige or from inflammatory products. So common is it to see shot and other wounds occurring withont material impairment of muscular motion that I do not think any one can challenge this statement. Indeed, the cases already cited in support of personal consciousness after wounds of the brain are, most of them, equally pertinent when applied to the maintenance of motility. Nor does the fact that a man falls, or is unable to rise, after a perforating shot wound of the skull, prove that the power to use his arms is lost. The missile may damage the leg-centres and not affect the arm-centres.

Let us next change the proposition by altering the order of wounds, the heart wounds taking precedence.

The unconsciousness and loss of power which follow wounds of this crgan are due to hemorrhage; the ressels of the brain and other nerve centres being suddenly empticd of their blood, fatal syncope ensues; hence wounds of the heart are generally considered to be instantaneonsly fatal. Yet there alre many-very many-exceptions to this rule. Fischer, in an analysis of 452 cases of wounds of the heart, gives no less than 35 recoveries; 72 were shot wounds, with 12 recoveries. Dr. P'urple, in his collection of heart wounds, states that in 42 cases. 12 of which were shot wounds, death did not take place immediately.

While it is true that these statistics are not altogether free from eriticism, yet they possess an intrinsie value in establishing the general statement that these injuries are not necessarily or immediately fatal in all instances.

The following cases, culled from different sources, will go to sustain the object most needful for my present purpose. In 
the "Surcical History of the War," part i, pages 530-31, there is recorded the case of Private lamning, Co. A, Pennsylvanial Volunters, who was shot in the chest, the ball entering the right anricle of the heart. The patient persisted in sitting up and walking about his room. IIe lived for fourteen days. The same anthor mentions the case of a private named Wright, Co. C, Fourth Regiment of the Veteran Reserve Corps, shot at (Quincy. Ill., who lived forty-six hours. The ball passed throngh the lung, the left auricle, the auriculo-ventricular septum, and the left rentriele.

In two instances, given by Jamain, the patients lived six months after a shot wound of the left rentricle of the heart. Ferms mentions a case in which a man lived twenty days with a skewer through his heart.

Sir William MacCormas writes me that Mr. Durham had a case of bayonct wound of the heart, in which the patient survived fiftr-six hours. The wound implicated both rentricles, the septum and auricle, and yet the man walked some yards after receiving the injury. Dr. Andrews reports a case under the care of Profesior Bergman. of Dorpat, where the injured man traveled fifteen miles to I)orpat and finally recovered.

In the Luncet, January. 1879. a case is reported where a man received a perforating shot wound of the left ventricle, which did not prove filtal for fifty-four days, the patient having, in the meantime, returned to lis work.

In Ramkin's '. Mbstract of Mrolical Sciences," vol. xxxi, page 16.5, Mr. Jarlison reports the case of a man who received two shot womuls. one of the balls passing through the right ventricle. Ho lived for three and a half hours and was able in the montime to make a deposition and name his assassin. A (a) of anamination was tried before a British court in India. Initive nalmed Kadir was shot through the heart, June 2, l47.9. while lying on his cot. It was stated in evidence that the rictim. alter receiving the fatal wound, recognized and denomnerd his murderer, a man named Meera Khan. On the 


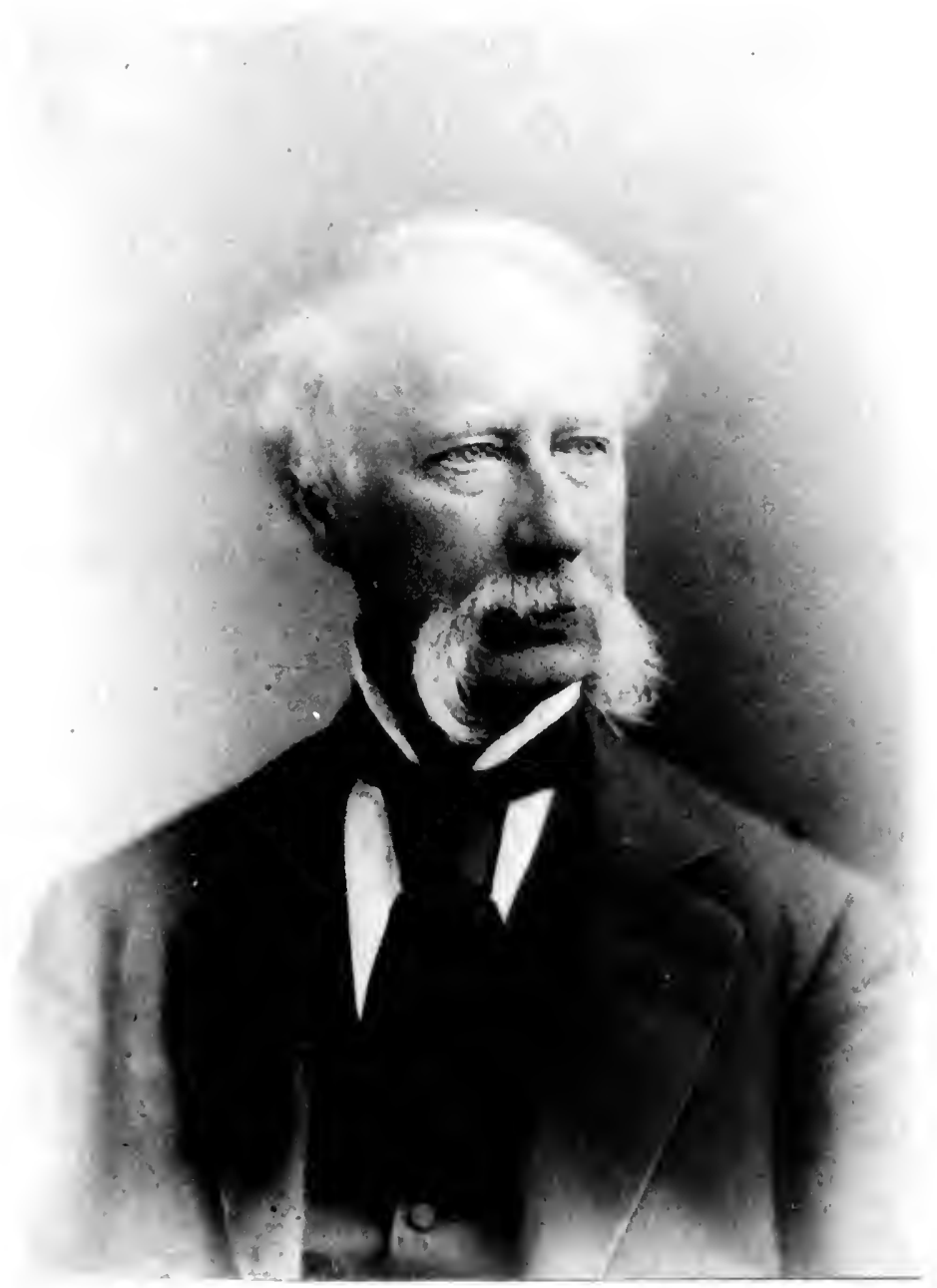

Dr, AgNeW IN 15ig. 
strength of this testimony the assassin was found guilty. An appeal was made and the case carried to another court, and the verdict reversed on the ground that death must lave been instantaneous. Mr. W. Curran, Brisade-Surgeon, in commenting on this case, stated that the decision of the former court was, in his judgment, correct, as, in his own personal experience, shot wounds of the heart were not necessarily immodiately fiatal.

On May 11, 1812 (Lancet, April 2, 1887). Mr. Percival was shot by Bellingham in the heart. At the trial a witness testified that after the firing he saw the murdered man rush hastily through the crowd toward the place where he was standing, looking first in one clirection and then in the other, and, after taking a few steps more, reeled and fell to the ground.

I may also mention the case of a woman brought into the surgical ward of the Pennsylvania IIospital during my term of service. The left rentricle had been pierced by a butcher-knife. She surrived for two and three-quarter hours, and for one-third of that time her mental condition was perfectly clear.

Can any one doubt that, in most of the cancs cited, these patients, had they been so disposed, could have intlicted a shotwound of the head?

And now, third and last, are there any instances in which a suicide has actually inflicted the two wounds which I have been considoring?

Dr. Macleod, Professor of Surgery in Giasgow Lniversity, Scotland, furnishes me the case of a suicide which canne directly under his observation, which is to the point. I student shot himself in a closet, the ball entering the head. Finding that he had not accomplished the work of self-elestruction, he went to his bed-room, along a passage, and shot himsclf in the heart. He lived only a few moments alter this lant injury.

In turming to the records of the cononer's physician in Philadelphia. I am able to fiminh the following cases:-

1. A policeman shot himself. first through the head; the ball, entering the right temple, was found lodged in the cranial 
vault on the opposite side. A second shot was fired into his chest, the bullet cutting the right side of the heart. Death from intemal hemorrhage followed in about five minutes. This was done in the presence of witnesses.

2. A boy, aged 19, inflicted four shot wounds from a revolver on his own person. The first bullet entered the forehead and, after taling a circuitons route, lodged about the mildle of the left temporal lobe. A second ball was fired into the chest, and, passing through the sternum, cut through the left ventricle of the heart on a level with the mitral valve. A third slot passed into the abdomen, and a fourth into the neck. Death cusued from pericardial hemorrhage.

3. A grocer was found dead in his room, having locked the door. A pistol was still clutched in each hand; one bullet had pasied through the brain and a second through the heart.

4. A man committed suicide in the park; one ball entered the brain, a second the chest.

In all these cases the suicide was not assumed, but proved beyond all reasonable doubt.

From the foregoing facts, which are thus hastily thrown together. I think I am at liberty to draw the following condusionis:-

livest. 'That it is possible for a ball to enter the brain without destroyinu conscionsness, although it mar, for a few minutes, caure some mental confusion.

Secomel. 'That a ball may traverse the brain without causing muscular paralỵis.

Third. That a suicide may, with his own hands, if so dislosed. tirst shoot himself in the head, and, within the lapse of a minnte. inflict a similar wound on the heart, and that there is a sufficient number of cases on record to establish the feasibility of the selp-infliction of the two shots; and

Fonifll. That a suicide may first discharge a ball into the chent. wounding the heart, and immediately after send a second ball into the brain. 
In the second article by Dr. Agnew, he studies the tendencies of modern life as related to surgical disease. It has been stated by many authorities that this essay should be found in every household in America :-

\section{THE RELATION OF SOCIAL LIFE TO SURGICAL DISEASE.}

President's Address Delivered before the American Surgical Association.

There is no tyranny more exacting or despotic than that exercised by the conventionalities which gorem our living. All stages of life, from infancy to old age, are under its domination. It dictates the education, the manners. the walk, the dress, the forms of speech,-in fine, the whole being. Berond all contradiction, the behests of fashion are vastly more influential in governing public conduct than any argument drawn from the teachings of structure and function. As a rule, when the conflict is between taste and reason, the rictory will be on the side of taste. In nothing is this more forcibly displayed than in the apparel used to protect the body.

It is not an agreeable task to peer into the wardrobes or dressing-rooms of our fair country-women. I have no especial taste for exploring museums or lizure collections. Indeed, without a key to interpret the curious and ingenious mechanisms for clothing the form dirine, such an exploration would be like an archæologist attempting Egyptology ignorant of cuneiform inscriptions.

I have, however, some knowledge of human anatomy in its broadest sense, and when I look upon the master-pieces of the human form, whether in marble or on canvas, a Belvidere Apollo or a Venus de Medici, and contrast these with the specimens of modern mon and women, I am forced to aldmiration; not so much at the amazing ingenuity displayed in concealing the divinely appointed form as at the plasticity and patient submission of mortal clay under the despotism of a conventional inquisition. 
Were these processes of mutilation and abnormality harmless,-did the body consist of a mere mass of protoplasm capable of assuming protean shapes, the subject might be passed over with the feeling of a naturalist; but this is not so, These violations of the laws of structure bring with them serious penal inflictions which, did they terminate with the original offender, might bo dismissed with a sentiment of pity; but projecting, as they do, their bancful consequences to snccessors, they become proper subjects for criticism.

Let me name a few examples as illustrative of ny subject. For some time the profession has been speculating on the cansation of masel and post-nasal catarrh, with its accompanying auditory defects, the growing frequency of which cannot have escaped general observation. Doubtless no single agency will explain the presence among us of this umpleasant disease; yet there are fiucts comnected with this affection which, to me, are very sugestive. I cannot recall an instance in which I have met with the disease among women belonging to the society of Friends, Dumkards, or Memonites. If this, on more extended oberration, proves to be true, may not the head-dress peculiar to these people be accepted in explanation of their exemption.

The bonnet which, at one time, overshadowed the entire head. a all know, has been gradually shrinking in its dimensions until it has become a mere shadow of its former self and offer's no protection whatever to the head. As a substitute, I would not insint upon the quaint head-gear of the Friend, but I bolieve that any modification which will protect this lant of the body will lessen the tendency to catarthal inflammation of the batos-pharyngeal mucous membrane.

1 logion of physical imperfections arises from muscular restrmint. Amone these may be mentioned weak ankles, narrow or contlarted rhests, round shoulders, projecting scapulæ, and lateral curvatum of the spine.

The fooli-h concession to appearance and the unwise par- 
tiality of parents for enforced systems of education, the demands of which bear no just proportion to the capacity of the jurenile mind, constitute the initial or determining force of these physical imperfections. In many cases the weak ankles of children, characterized by eversion of the feet, thus allowing the superincumbent weight of the body to be transmitted to the latter, inside of the proper centre of support, is largely chargeable to the miserable practice of placing on the little ones, long before they are able to walk, boots tightly laced up the limb some distance above the ankles. The confinement of the flexor and extensor muscles by this constriction prevents that free play of movement which reacts so favorably on all the clements of an articulation, and that, too, at a time when the growing forces are at full tide; so that, when the time arrives for standing and walking, the muscles are unequal to the firm support of the joint.

The consequence of this feebleness is soon seen in the turning ontward of the feet, throwing the strain on the internal lateral ligaments, which, in turn, become elongated through growth, and thus the defect becomes established. But the cril does not stop here. The calcaneo-cuboid and the astragaloscaphoid ligaments, losing the proper support of the tendon of the posterior tibial muscle under the abnormal tension, begin to yield, and to the deformity of eversion is added that of "flat-foot." That this is not a more hypothetical explanation of the ankle defects I have many times verified by finding the threatening symptoms disappear after liberating the imprisoned muscles and subjecting the enfecbled parts to a judicious massage. Under no circumstance, as is too often the case, should instrumental apparatus be applied, muless in cases in which, from neglect, the deformity is thoroughly established and is progressive.

Take another deformity, that of "bow-legs." On the earliest signs of the unsightly curve, the limb is too often trammelled with irons and the growth of the muscles arrested, when 
it is well known that if manual force be systematically applied two or three times a day the limbs will grachally assume their typical form.

Agrin, in further illustration of our general text, take as an eximple a child who, for one long or two short sessions for five days of the week, sits over the study desk, compelled to assume a position in which, from the inclination of the body, the shouklers fill forward, the head being supported generally on the elbows and the hands. In such a posture the great serratus, pectoralis major and minor muscles are in a state of relaxation, while the crector spinx and trapezei muscles are in a state of tension. This change in the position of the shoulders gives the shoulder-blades over, without antagonism or resistance, to the action of the rhomboidei and the levatores angulæ muscles, which, acting conjointly, cause that projection of the lower angle of the shoulder-blades which the older anatomists termed "scalpulie alatie."

'I'o all this must be added the very important factor of four to six hours in the school-room and two hours, at least, of home preparation for the following day's recitations, during which time the respiratory functions, having been reduced to a minimum of actirity, the muscles of the chest are comparatively pasive and äration of the blood tardy. Certainly no combination of conditions conld be better derised for forming contracterl chests and romnd shonlders.

It is not long before the watchful eve of the mother detects the change in the figure of her child. She will probably discover this condition and talie alarm, eren when the pale face, the languid alr. and the capricions appetite of the child causes 110 anxiety; and then comes the second act in the drama of physical deterionation, - a resort to shonlder-braces and stays in order to accomplish that which the muscles should be taught to do withont restraint or incumbrance.

While it is true that lateral curvature of the spine depends upon causes both central and peripheral, yet in no small num- 
ber the deformity is clearly attributable to influences of a social nature. The spinal column, by reason of the non-mion of the epiphyses and diaphyses and the supple character of its ligaments, is extremely flexible. Whatever, therefore, destroys the muscular equipoise, howerer inconsiderable the force, if persistently repeated, changes the centre of gravity and develops primary and compensating curres.

For nine months in the year, any fine morning, groups of young children may be seen plodding along our streets with a miniature library of books suspended from one shoulder. To the already preponderating scale of the balance add the additional factor, a badly-arranged light in the school-room, compelling these little savants to assume a lateral inclination of the body in order to obtain the necessary illumination of the subjects of study, and you have all the conditions necessary for perpetuating the lateral deformity. "Just as the twig is bent the tree's inclined." As in the case of round shoulders, in order to prop up the falling column, instrumental contrivances are immediately called into requisition. The body is encased in a formidable coat of mail, to be followed by muscular atrophy and permanent distortion of the most beautiful piece of mechanism in the liuman frame.

It is true that in most educational institutions for the young provisions are now made for physical culture, and these are, in some measure, antidotal to the crils complained of'; but, in my judgment, these factors do not at all compensate for that free unstudied romp in the open air so fascinating to the young child, untrammelled by the hard and fast rules of calisthenics or gymnastics. Nor does the eril end here. While the forcing process, which is to stimulate the mental powers fir beyond the real capacity of the immature and growing brain to receive, is in progress, another is inangurated which is to qualify, especially the female child, to acquit herself with distinction when the time arrives for entering the great world of society, or, as Thomas Brown would style it, "for the frivolous work of pol- 
ished idleness." The gait and carriage must be reduced to prescribed rules, the roice toned down to a drawl; the muscular apparatus of the face must be taught to express not the spontaneous and natural outcome of feeling which wells up unbidden from the magic chambers of the heart, but rather to produce in effect. And so this work of transformation goes on until it culminates in the full-blown "society girl." Is it any wonder that-under such a scheme of education, conducted throughout by a studied disregard of both the physical and mental constitution, and exercising, as it does, such tremendous drafts on the nervous system-the world is being filled with a class of flat-breasted, spindle-limbed young women, unfitted for the varied and responsible functions of womanhood; qualifications, too, which, under a different regimen and directed into proper channels, would exert a most potential influence on all the great social and moral problems of the age?

While thus plain spoken on the frivolous methods of living, I do not wish to be understood as being unfriendly to the highest cultivation of the mental and physical powers, if conducted on lines in harmony with the organization, nor to any technique which may conduce to personal grace or elegance of manners, so that the manly or womanly personality of the indiridual be not sacrificed to the Molech of sentiment and sham. Indeed, indifference to these matters is inexcusable in either man or woman, as not only lessening their influence in the world, but, in many respects, disqualifying them for the highest discharge of the duties of modern lile. Valuable as may be the unpolished diamond, yet it is only after the wheel of the lapidary has worn away the dull incrustations that its true brilliancy is revealed, and the gem is fitted to adorn the brow or breast of beauty.

In the funther discussion of my subject, I may next notice the evils of risceral displacement consequent on abdominal constriction. Whatever may be said in regard to Greek and Roman life, the infinite care which these people displayed in developing and maintaining the rery best type of the human 
form is worthy of admiration and emulation. The Ionic "Cheton," spoken of by Attic writers, and so often represented by the bronzes of Herculaneum, while it would not exactly satisfy the modern idea of dress, was, at least, free from the charge of interfering with the contour of the human figure.

The painters and sculptors of those classic days were reverent students of Nature. Their delineations were true to life. Their works furnish us with no hour-glass contractions of the human body. The constriction of the waist operates injuriously on both the supra- and infra- diaphragmatic organs. Any force acting on the base of the thorax and preventing the expansion of its walls concentrates the function of respiration, which should be general, on the apices of the lungs; and hence, under these circumstances, the movements of breathing are for the most part confined to the summit of the chest. As the seat of tuberculosis is generally located in the upper part of the lungs, may not the inordinate work entailed on these parts by constriction have some influence in hastening such deposits in the female when the predisposition exists?

It is this forcing inward of the costal border of the thorax which causes the groove on the anterior surface of the liver so familiar to anatomists. The pressure cimnot fail to interfere with the descent of the diaphragm, and with the functions of the gall-bladder and duodenum, and exercises no small degree of influence in faroring the formation of gall-stones, females being peculiarly prone to such eoneretions. The extent to which the liver may be damaged by extreme constriction of the waist is well illustrated by a case recently reported in the British Medical Journal, in which a considerable portion of the left lobe of the liver had been separated from the right, the two being comnected only by a band of comnective tissue, which enabled the operator to remove the detached mass without difficulty.

'The evil effects of this constriction on the viscera of the abdomen and pelvis is most strikingly witnessed in the embarrassed portal circulation, in the different uterine displacements, 
clongation of ligaments, displaced ovaries, tubal inflammations, hemorrhoids, hernia, and other morbid conditions, which either prevent or disqualify the woman for the excreise of the functions of maternity, and which, in addition to reflex influence, cutail a host of functional disorders reaching into every avenue of the body and invaling both the mental and moral constitution of the rictim.

So prolific have these infirmities become that a new depart. ment of surgery has been organized for their special management. 'To what, if not to social causes, can be these morbid changes of structure in the pelvic organs, especially of the uterus and its appendages, be attributed? Why should laceration of the cervix uteri be so common an accident? Labor is a nataral process, and eught not, under ordinary circumstances, to be attended by lesion of uterine tissue. I can conceive of no agency more likely to induce that muscular degeneration which predisposes to this accident than the modes and methods of modern living, especially among the inhabitants of great cities. In the expression "modern living." much is embraced. It includes culinary pharmacy, overfeeding and overdrinking, insufficient or injudicions exereise, improperly heated apartments, and a disproportion between the hours of exercise and rest.

Contrast, if you will, the muscles of the hardy country honsewiti. who, bearing the cares and responsibilities of a depentent limily, bustles about the livelong day, in-doors and out-of-doors, cats with a relish her plain and simple fare, repairs at reasonable hours to bed, sleeps the sleep of the just, undisturbed by dyspeptic night-mares, and, rising with the golden diwn. resumes the round of domestic toil with a clear head and supple limbs; I say-contrast this type of a class with that of another, - the woman born to luxury and ease, whose capricious and exacting taste taxes the arts of the professional caterer, who drags out the morning hours toying with some crazy piece of embroidery or trashy novel, lunches at one, rides out in the afternoon for an airing of two or three hours, returns to a din- 
ner of five or six courses at seven, completes the evening at the opera, the theatre, or the assembly, and, coming home after midnight, crawls into bed, weary and exhansted in mind and body, only to rise, with the best hours of the morning gone, for another day of aimless, routine life.

Can it be doubted that in the first case, with a digestion unimpaired, with the products of textural change consumed by functional activity and eliminated through the proper cmunctories, the woman should possess a vital resistance and a tone of tissue altogether superior to that of the other, whose habits of living must necessarily favor their faulty metamorphosis?

To these same agencies must be attributed that brood of nervous and hysterical evils for the relief of which the gynecologist too often, I fear, invades the domain of womanhood around which her whole sexual nature revolves, and which, save in the direst extremity, should be sacred against all operative intrusion.

Late mamiages constitute another social evil, the penal inflictions of which in rolve both sexes alike. Pride and luxury determine long engagements or deferred proposals. Marriage, it is believed, necessarily involyes an establishment, a display, a retinue of servitors. The good old notion of two souls being united in wedlock for the purpose of being mutual helpmates, and patiently together working up from modest begimnings to affluence, seems to be entircly at variance with the modern idea of this relation. In the meantime the young man is betrayed into unlawful sources of gratification, alike destructive to moral and plyssical purity, the pollution of which incontinence is often communicated to and perpetuated in wile and offspring. I would not dare to say low many cases of this nature have been entrusted to my professional confidence, although I doubt not my experience does not differ from that of many of my professional brethren.

It may be thought by some persons that the subject of the foot and shoe is not of sufficient dignity to appear in a public 
address. The Romans and the Gireeks thought differently. 'The literature of both people is full of reference to the shoe worn by both sexes. So important, indeed, are the feet to the well-being of the body that whatever impairs their usefulness, either for support or locomotion, becomes a positive calamity. Nothing, scarcely, is less like the human foot than the modern shoe. Let any one leare the impress of his or her foot in the wet sand of the sea-shore and then place alongside of the imprint a fashionable shoe; that the two were intended for each other would scarcely strike a child of the forest. The North American Indian entertains greater notions about clothing this portion of his body than does the civilized denizen of New York or Philadelphia.

Compare the moccasin with the French shoe of the city belle. Compare the $\sigma \alpha \nu \delta \alpha \lambda_{0 \nu}$ or the $\pi \varepsilon \rho \sigma \chi \alpha \alpha$ of Pollux and Aristophanes with the same, and we shall see that the sarage and the polished Greek alike understood the value of sound feet in the race of life. It is the imperfect adaptation of the shoe to the foot which constitutes the fintitful source of tired ankles. corns, bunions, overlapping of the toes, and ingrowing nails. Some idea may be formed of the magnitude of the evil from the fact that, of 800 patients under the care of a prominent chiropodist of Philadelplia, the great majority of the defects were entirely attributable to the contracted toes and high heels of the shoes. Especially do these physical incumbrances arising from a blind submission to social laws operate disadvantageonsly to our fair women at the beginning of the new dispensation, requiring both muscle and brain, and when her friends propose to sweep away all the old traditions and claim for leer the earth with all its masculine employments.

firmes and amusements, which, in themselves, are proper and praiseworthy, too often become developed into a craze, working both moral and phrsical mischief. In the national game of base-ball there is the "pitcher's arm," a condition of orertaxed function, and one in which all the anatomical ele- 
ments of the upper arm are involved. There is also the "tennis arm" and the swollen, supersensitive prostate of the bicyclist, both due to abuse of proper popular amusements.

Defects of refraction, or defects of vision, constitute another class of affections fairly attributable, in many instances, to social influences. The number of children who may be seen on our streets any day wearing glasses has become a matter of common observation. It is far from being probable that the most exquisite piece of mechanism-the human eye-came from the Divine Artificer imperfect.

Because eyes are young, it does not follow that they are thereby better fitted to sustain prolonged use. Just the reverse is true, and it is high time that parents and edncators begin to realize this fact. 'The power of the eye for continued use, like that of other organs of the body, is one of gradation. It moves in the general procession and strengthens with the adrance in life until development has attained its zenith. Not only so. but the eye, being a part of the body, must suffer or rejoice through the operation of general causes. A bone may lave its normal curves changed, a tendon may slip from its appointed groove, or a blood-ressel be destroyed, and yet very little disability be realized; but the eye is made up of snch extremely delicate structures, and acts according to fixed physical laws, that not the slightest alteration of a curve, or the mobility or density of its media, can occur withont great ritiation of function.

To exact long hours of study from children of a tender age involves a degree of functional strain altogether disproportionate to the structural resoures of the organ, and. by disturbing the orderly processes of nutrition, gives rise to hypermetropia, asthenopia, astigmatism, and its companion, headache. That the picture is not too lighly colored or the sensation overstrained, we have only to contrast the children born and reared in those portions of the country not too much dominated by the methods of modern cirilization and who rarely demand a resort to artificial aids to provide for abnormal- 
ities of vision. The only remedy for the evil, where infantile scholarship is insisted upon, is the kindergarten, or object system,-the most natural and effective plan of impressing the young mind.

Is there any reasonable explanation drawn from sources of a social nature for the great frequency of those renal diseases which come more particularly under the care of the surgeon as crystalline deposits and calculi? For maintaining the general health at the highest physiological standard, a proper quality of food and the proper disposal of tissue waste are essential conditions. Along with wealth and luxury come the abuses of the table. Americans are fast becoming a nation of dyspeptics. The country is so rich in the products of every zone that nowhere else in the world can you find such a variety of of foods, animal and regetable. These foods, manipulated in a thousand ways by the subtle art of the professional cook, almost necessarily betray one into excess and also create the desire for wine and other alcoholic beverages to aid the stomach in disposing of its plethoric supply.

In great cities, which fumish relatively the largest number of cases of renal disease affecting pre-eminently the mercantile and sedentary classes, we find just the conditions farorable to their derelopment. The competitions of trade lieep the merchints always at white heat. Time is golden, and the street-car and other means of conveyance annihilate distance and the ride is sulstituted for the needful one. A lasty lunch at the most conrenient restaurant satisfies the inner man until the business of the diy is closed, when, weary and worn, he is driven to his home to partake of a course dimner, the balance of the evening to he spent on the lounge with the evening paper or the latest preriodical. To the literary man, the fascinations of the study and the library charm him away with their syren voices from the ticlis and highways until bodily exercise grows distasteful and repuenant. In the meantime there has been no provision made for the waste or tissue metamorphosis of the body through 
that great agency, exercise. These accumulate in the blood. The internal eliminating organs, of which the kidneys are chief, are overtaxed, and then follow the evils of malassimilation and of excretion, in the form of urates and oxalates, often resulting in the formation of calculi.

In conclusion, may we ever hope for a time when the race will realize that these bodies which we wear, which God has so highly honored by His own incarnation, are sacred temples, to be kept in harmony with recognized physical laws, and not to be made instruments of mere animal gratification. 


\section{CHAPTER X.}

\section{The Garfield Case.}

On the $2 \mathrm{~d}$ of July, 1881, James A. Garfield, then President of the United States, was shot in the Baltimore and Potomac Railway Station, at Washington, by Charles J. Guiteau. The motive of the assassin was never fully determined. It was discovered subsequently, however, that he was one of that vast swarm of applicants for position who fill Washington at all times, demanding or hegging fitvors of government officials. He had written to the President asking for the Paris consulship; his application had been referred, with thousands of others, to the proper department. Gnitean undoubtedly was consumed with an overweaning desire to become notorions, in which ambition he was not restrained by the possession of a strong moral nature, or any great degree of mental power. With the cumning of his low intellect, he reasoned that if he should remove the President, naturally all eyes would be attracted to him, and his name would be on every tongue. There would be thrown around his name the romance of a Willes Booth, while he would be protected from punishment by the opposing branch of the President's party, out of gratitude for placing them in power by the change.

President Garfield was on his way to a remion of his class at Williams College; accompanied by Mr. Blaine, Secretary of State, and Colonel Rockwell, he was standing in the ladies' waiting-room at twenty minutes past nine on the morning of July 2.l. The assassin approached him from the rear, coming within a distance of six feet, firing two shots from a powerful revolver of 42-calibre. One shot went through the President's coat-slecre, but the other struck him in the back, felling him to the grome. He was carried at once to the second story of the station building and placed upon a mattress, several physicians (220) 
who happened to be in the vicinity administering stimulants to him. ${ }^{1}$ At the suggestion of Mr. Robert Lincoln, Secretary of War, Dr. D. Willard Bliss was summoned.

Dr. Bliss foumd that the point of entrance of the ball, which was oval and sharply marked, was on the right side, in the tenth intercostal space, four inches from the median line of the spine, and on a line with the eleventh rib. A slight dischirge of blood was oozing from this orifice, and had stained the clothing. Dr. Bliss passed a Nélaton probe through the tenth intercostal space, downward and forward for a distance of three and one-half inches from the surface of the body, to what appeared to be a cavity, but he was unable to detect any foreign substance, beyond the rib, to indicate the presence of fragments of bone or the missile. In attempting to withdraw the probe it became engaged between the fractured fragments and the cud of the rib, and could not be freed until pressure was made upon the sternal end of the rib. Dr. Bliss then passed the little finger of his left hand, to its full length, into the wound, which showed the character and extent of the fracture of the rib; but he was able only to rach a point on a line with the inner surface of the rib, where his finger came in contact with what appeared to be lacerated tissue or comparatively firm coagula of blood-probably the latter.

After withdrawing his finger, Dr. Bliss made an exploration with a long, flexible, silver probe, which he suitably curred before introducing, and gently passed it downward and forward, and downward and backward. with a riew of determining the course of the ball, if it had been deflected by contact with the rib; but, meeting with resistance from soft parts in all directions, Dr. Bliss desisted, being inclined to the belief that the ball had entered the liver, which, if true, would not warrant further exploration in that direction.

By this time a large number of pingsicians had gathered in the room, and Dr. Bliss gave them a hurried account of his

1 The physicians in attendanee immaliately after the shooting of the President were Drs. Townshend, Purvis, Reyburn, Norris, Lincoln, Patterson, and J. B. IIamilton. 
examinations and expressed the opinion that no further explorations should be made during the stage of collapse, and that stimulants by the stomach should not be given at that time, as the President was suffering from constant nausea, and in his condition absorption would not take place. The President repeatedly requested that he be taken to the White House, and, after a further consultation and a full understanding of the manner and detail of his transfer, his speedy removal was agreed upon.

Temporary dressings were applied to the wound, and the President was placed upon a stretcher, carried down-stairs, and placed in an ambulance in waiting. The vehicle was driven with great care to the White House, the President not. experiencing any discomfort. He was taken to his room, which wats known as the Southwest or family room of the house. On the arrival of the President at the White House a careful examination was made of his condition. His pulse continued feeble, frequent, and exceedingly compressible; the respiration was slow and sighing; his extremities and the surface of his body were cold; he had been romiting freely; his entire body was bathed in a profuse perspiration; his roice was husky: he constantly complained of severe pains in the limbs. He was placed on his right side, so as to make the wound dependent, to facilitate drainage, and keep the viscera in contact with the injured walk, looking for the possible adhesion of the injured parts to the preitoneum. It was deemed improper to remove his clothing at this time. Water was given in small quantities, often repeated. This was necessitated by the extreme thinst from which the patient suffered. A hypodermatic injection of $\frac{1}{8}$ grain of morphine and $\frac{1}{80}$ grain of atropine was administered, to control the pain in the cxtremities and as a more permanent stimulant to assist reaction.

'This was at 10 o'clock on the morning of July $2 \mathrm{~d}$. There was but little change in the condition of the patient, either in temperature, respiration, or pulse, until 11 o'clock, when it was determined to repeat the morphine in a dose of $\frac{1}{6}$ grain. 
This had the effect of modifying the pain and discomfort, and the respiration became more frequent and easy. The pulse responded, however, but feebly to the stimulants. Nausea and vomiting continued at intervals of thirty minutes during the entire day and until 7 in the evening, when it became less frequent, being simply a regurgitation of fluids from the stomach. This condition returned at longer intervals until 6 o'clock the following morning.

At 5.30 P.M., in accordance with a previous understanding with the physicians, the clothing was cut from the body in such a way as to prevent any motion or agitation, and to permit a more successful application of dry heat by warm flamels to the entire body, which had been imperfectly accomplished before. Examination showed a well-defined field of dullness over the region of the wound, thought to be due to hemorrhage from the substance of the liver, along the supposed track of the ball, extending seven and a half inches antero-posteriorly and five and a half inches laterally. At the evening consultation, held July $2 \mathrm{~d}$ at 7 P.M., the opinion was expressed, as a result of this examination, that internal hemorrhage had talien place, and that, in consequence, the distinguished paticnt would not survive the night. At 10 P.M. the pulse was 158 ; temperature, $96.5^{\circ} \mathrm{F}$.; respiration, 35 ; but at 11.20 P.x. the evidences of reaction began at last to manifest themselves. The pulse diminished to 120 ; the temperature and respiration became normal.

From this time till 2 P.M. on $J_{11 y} 3 d$ the variations of the pulse were comparatively slight, ranging from 104 to 120 , the respiration and temperature being normal. The patient slept at short intervals, generally arousing with an effort at reguroitation of the contents of the stomach, but otherwise expressing a feeling of comfort and showing evidences of rest. During the night he seemed to be refreshed, and was comparatively free from pain. There was no period up to this time that the patient was not perfectly rational, and he often made brief, 
pertinent inquiries as to the character of the wound and his condition.

There was some oozing of dark venous blood during the night, sufficient to saturate the carbolized cotton, which was used as a dresing, and stain the bed. On the following morning the hemorrhage had entirely ceased, and the dressings became adherent to the skin. The physicians invited by Dr. Bliss to risit the bedside were Surgeon-Gencral Wales of the Navy, Surgeon-General Barnes of the Army, Surgeon J. J. Woodward, Dr. X.s. Lincoln, and Dr. Robert Reyburn. At the consultation held the monning of $\mathrm{Jul}_{\mathrm{y}} 3 \mathrm{~d}$, the patient was found with a pulse of 115 , with his temperature and respiration nearly normal. He was cheerful, gare evidence of being rested, and made definite inquiries regarding his condition and prospects. The use of morphine hypodermatically, in doses of sufficient quantities to control the pain in the extremities, was continned.

It this time the resumption of all the normal functions of the kidneys, bladder, and intestines showed that no internal organ had been injured. Slight trmpanites was detected, but these was no other evidence of anything, during the whole course of the ease, which pointed toward the existence of peritonitis.

- Immediately after this consultation, the subject of medical attendance was considered by the President. He placed himself formally in Dr. Bliss's professional care at this time, and requesterl him to select his own comsel.

I)r. Bliss, realizing the great responsibility of his position and the necessity of selecting such medical authorities as would miverally be conceded to be the leaders of the profession in America, decided to summon Dr. D. Hayes Agnew, of Philadelphia, and I)r. Frank II. Mamilton, of New York. At the same time Mr. Wayne MacTearh, the Attomey-Gencral of the anministration, had also urged upon Mrs. Garfield the propriety of taking 1)r. Agnew into the case.

1)r. Agnew receired the message that he was wanted, at. . 
midnight of July 3d. IIe was at that time spending the summer at his country place, "Wyndrift," at Haverford, near Philadelphia. Attorney-General Warne Mac Veagl telegraphed to Mr. A. J. Cassatt, at Haverford College Station, recinesting him to determine whether Dr. Agnew would rome at once to Washington, and, if so, to make arrangements for a special train. It was necessary to repeat the message at Philadelphia. where it was shown to the Night Dispatcher of the Philadelphia I)ivision of the Pemsylvania Railroad, who, anticipating the orders that he knew he would receive, immediately dispatched a special train to IIaverford College Station. So quickly was this done that the train reached the station before the message returued to the dispatcher, and by the time Dr. Annew was dressed and ready he was carried, without a second's delay, to Philadelphia. The train left Giar's Ferry, Philadelplial, at 1.10 A.M. and arrived at Washington at 4.01 A.M., making the num of one hundred and forty miles in one hundred and seventy-one minutes, being the quickest trip on record. between Philadelphia and the Capital, up to that time. Dr. Frank II. Inamilton quickly followed from New Tork.

The President had passed a comparatively comfortable night, awakening erery twenty or thirty minute taking water or liquid nourishment in small (puntitien anch time. and drop)ping quickly to sleep. The nausea harl subsided. and the pain and soreness of the lower extremities were controlled by the

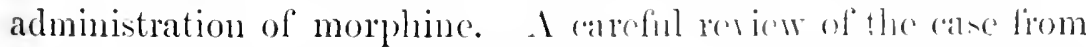
the time I)r. Bliss first saw the Presilent was given to his new consultants, with the request that they with the data before them, examine the case thoronghly, as if it were their own. and express freely their views of the character and gravity of the injury and the course of treatment of the ase up to that time. Dr. Bliss also gare them a detailed ancemint of the explorations made in the wound, and the misettled convictions then held as to the course of the missile, and the organs involved in the injury. 
The new consultants examined the case separately with great care. They studied the data of the progress of the symptoms for the first forty-seven hours, and eximined the wound thoroughly. The more prominent data upon which the diagnosis could be based were as follow: The relative position of the assassin to the President at the time of the shooting; the direction of the ball through the tissues, so fur as safe exploration could determine; the appearance of severe pains and lyperesthesia in the limbs, especially on the right side, with their gradual subsidence or modification; the repeated unsuccessful efforts to pass a probe or fiexible instrument more than half an inch in any direction beyond the fractured rib, except in a direction downward. a little forward and anterior to the twelfth rib, a distance of about two inches. The fact was also considered that explorations laad twice been made with the finger, once by Dr. Bliss soon after he reached the injured President, and subsequently by Surgeon-General Wales, of the nary, on the occasion of the consultation on the erening of July $2 \mathrm{~d}$, when in each instance it was found impossible to explore successfully beyond the inner border of the fractured rib. The consultants did not underestimate the significance of the profound shock, nor the unusual periorl of collapse which followed, and which seemed to point to extensive injury of important viscera. The hyperesthesia and continued pains, more marked on the right side, pointed to a moderate degree of laceration of nerve-trunks, but there was no eridence of injury to the spinal cord or its bony column.

The consultants did not attempt to force their probing with too great vigor; the condition revealed at the antopsy showed the wisdom of this policy. Probing sufficient to have grone any distance into the wound would undonbtedly have done fatal larm. as will be shown later, while it could not have revealed by any possibility the location of the ball.

The posible course of the ball was deciled to be in one of three directions: (1) rither into or through the liver; (2) backward at a right angle so as to involve the spinal column, or (3) 
downward behind the peritoneum into the pelvic carity. In regard to the first supposition, the consultants did not believe that the ball had passed through the liver, as had been surmised at first by Dr. Bliss. The suggestion that it had been deflected to the left and had injured the spinal column was considered, but the absence of paralysis showed that the spinal cord was uninjured; the tingling pains and hyperesthesia were probably produced by injury to some nerve-trunks or were reflex in character. The third supposition, that the ball had been deflected into the pelvic cavity behind the peritoneum, seemed the most probable, although this theory was not accepted as positive, being regarded by $\mathrm{Dr}$. Agnew merely as a possibility.

There was absolutely no data to show the course of the ball or its location to these men, whose trained minds would have detected the slightest indications, had they existed.

The propriety of making extensive incisions and dissections so as to explore the fractured ribs and remove as much as might be necessary to reveal the true course of the ball was considered, but the opinion was held by all the physicians that the faroral,le progress of the President thus far did not warant such interference, believing that such an operation would scriously complicate the case and diminish the prospects of recovery. The fact, well known in military surgery, that bullets become enveloped in cysts of connective tissue quickly, and remain frequently for years in living tissues without causing damage, also influenced somewhat this decision.

On the evening of July 4th the pain, hyperesthesia, and vomiting had nearly disappeared, but soreness of the feet continued for several days.

The President's condition remained so satisfactory that Dr. Bliss did not deem it necessary to call in the consultants again until July 23d. They were kept informed, however, by long, daily telegrams, of the condition of the distinguished patient.

The case progressed favorably, with fluctuations, until July $23 \mathrm{~d}$, when a chill occurred at 7 o'clock in the evening. Two 
days previons to this a pus-sac had been detected beneath the skin, extending down below the twelfth rib toward the erector spince ninscle and muleneath the latissimus dorsi; it was carefully evacuated by enentle pressure. The consultants did not feel satisfied, however, that this superficial and limited collection of pus. which was so readily eracuated, was the principal cause of the angration of the symptoms present; so a free incision was made into the pus-sace, which afforded a more direct and dependent chamel to the fractured rib, from which a small fragment of bone was remored. Pressure, made backward and upward upon the abdominal wall, caused a flow of peculiarly white and firm pus.

Alter this operation the improvement was not as prompt as the ronsultants had expected; and on July 26th the opening between the ends of the fiactured eleventh rib was enlarged, and a small detarhed portion was removed. 'This facilitated the discharese of pus, and. as a result, a more uniform condition of the symptoms was maintained until August 6 th, when a slight exacribation in temperature was noticel, which continued. It war diseovered at this time that pus harl disserted its way down behine the peritoneum into the right iliac fosia ; this was corrobolatory of the supposition that the ball had followed this conrse. It was necesing to racuate this chamel; consequently, on lugust sth the President was etherized, and an operation making a point of exit in the dependent portion of this pus-sale was done. the incision being carried downward and firmard through the slin, the subentaneous fiscia, external and internal obligue muscles, to the sinus or pus-chamel. It was discovered at this point that there was a decper chamnel, which laud not been exposed by the operation thus far, and the incision was carried through the transersalis muscle and the transveralis fascia, affording a free opening for the passage of all the pus.

The President did fairly well again, after this operation, until August $1 \mathrm{tth}$, when it was found necessary to resort to feed- 
ing by the bowel until Angust 17th, owing to the nausea, romiting, and general prostration which appeared. At this date the stomach was quieted gradually and the chemata were discontinued.

On August 18th a slight swclling of that portion of the right paroticl gland which lies directly in front of the ear was noticed. With this swelling there was no pain or tenderness on pressure. This parotitis presented many of the characteristics of an ordinary carbuncle, and was maccompanied by any other abscesses in the atjoining tissue. This swclling went on until suppuration was established, when mental disturlance, vomiting, and restlessness occurred. During the progress of this parotitis, facial paralysis occurred, and continued, with slight improrement, until the time of death. When the climax of suppuration was reached, a free discharge of ichorous pus followed, with a rapid abatement of the more urgent symptoms; and after the separation of the slough, which was limited in extent, a corresponding reparation was rapid and complete throughout the entire suppurating surface, as well as in the sereral incisions which had becn previously made to liberate the pus.

The question of malarial complication was riscussed at this time, but eliminated. During this time the pus-channel, which had opened, had been kept free from accumulations by washing it frequently and thoroughly with solutions of carbolic acid or permanganate of potassium.

During the latter part of August, a number of pustules of suppurating acne appeared in the armpits, and, liters, four or fire on the surface of the body. They were superficial, numbering ten or twelve, being about the size of lange peas; they were opened as soon as suppuration took place, hasled without recurrence, and were betieved to have been dur to the septic condition of the system. The small carbuncle mentioned in the report of the autopsy was doubtless referable to the same callse. The above were the only suppurating surfices, excepting the incisions made into the wound, and four small superficial bed- 
sores formed on the back, which were observed during the President's illness.

'l'he subject of the removal of the President to a more healthful locality had been discussed for some time; in fact, it han been considered all summer. The heat and oppressiveness of a Washington summer are to be dreaded, even by one in perfect health, although an efficient apparatus had been introduced into the President's room, giving an adequate supply of cold, dry air. The subject of his removal was urgently presented at the consultation of August 25th; but, as at this date the cliseharge of pus from the parotid gland lad not taken place, the majority of physicians present considered that his removal at this time would be attended with very grave peril. His diet throunhout the summer had been of a thoroughly and scientifically practical kind; it undoubtedly kept the President alive muder the most adverse conditions of continued gastric disturbance.

On August 26th there was a discharge of pus from the month, and from the ear through the anditory canal. It was believed that the pus which discharged in the month dissected its way along the course of Steno's duct, as there was rigidity of the marseter muscle; but the jaw was fixed so as to prevent the possibility of opening the mouth sufficiently for a satisfactory examination. Juring this period the patient occasionally wandered in his mind, although, when his attention was fixed by an attendant, his mental condition seemed to be comparatively perfect.

An interesting fact connected with the inflammation of the muenus membrane of the mouth was, that it extended by continuity to the pharysu, laryns, trachea, and bronchi. The physical signs developed the fact that acute bronchial catarrh had followed. IIypostatic congestion of the lumgs had been ob-rred for some weelis before, more extensive on the right side than the left, because of the President's position in bed. An improver condition appeared when the pus began to discharge from the parotid gland. 


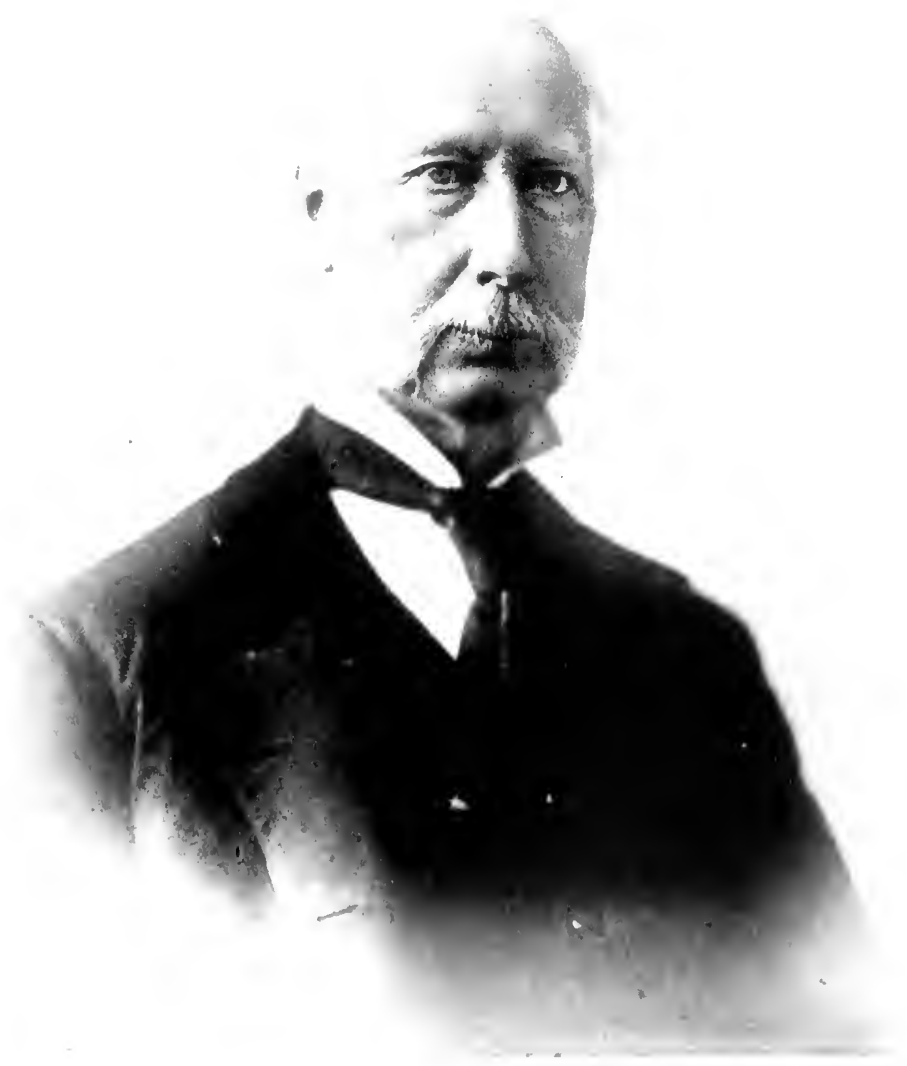

Dr. AgNeW IN 1982.

4 


\section{.}


Consequently, it was decided, early in September, that the patient was in a condition to be removed to the sea-shore. The details of his journey from Washington to Elberon, and the precautions taken to secure a safe and speedy transit, were perfect in every particular. Every provision was made to meet any emergency that might arise in the course of the journey, even suitable places along the line of the road being selected to which he could have been removed in case evidences of exhaustion had appeared. His transfer from the Executive Mansion to the cars was made with the least possible disturbance, without accident, and with perfect satisfaction and comfort to the patient. During the journey his pulse and temperature were taken from time to time, and frequent examinations made to determine the effects of the motion at different rates of speed. It was found that the President rested better when riding at the rate of sixty miles an hour. During the last hour of his journey he showed symptoms of fatigue, which would have prevented a longer journey, had such been required to reach his destination.

This journey of the wounded President was unique in the literature of railroad management. At every station along the line of the road crowds of men and women appeared,- - the former uncorered and with bowed heads, the latter often weeping. No sound of bells or whistles was heard; train-men ried with cach other in aiding the physicians. On arriving at the temporary track laid to the Francklyn Cottage, it was found that the engine had not the weight and power sufficient to pull the train up tine steep grade; instantly hundreds of strong hands laid hold and pushed the coaches up to thie level.

The President bore the jouncy well. It was the 6 th of September, 1881, and the bracing air of the carly fall at the sea-shore and the sound of the waves afforded him the greatest delight and satisfaction. The heat of the two succeeding days made but little impression on the distinguished patient. For eight or ten days his general condition risibly and continuously improved. The President was so much pleased with his 
improvement that he expressed a desire that the number of his professional attendants should be reduced. Accordingly, only Drs. Annew, Iamilton, and Bliss remained in charge of the case.

During the evening of September 15th, howerer, the inevitable change took place, his pulse slightly increasing, occasionally reaching 120 (huring the night. On September 17th, at 11 A.s.. a severe chill of half an hour's duration occurred, followed by a sharp rise in temperature. The mental disturbances were more noticalble during the febrile rise, but the stomach was still able to retain the nomishment and stimulants.

This rhill was accompanied by agonizing pain over the chest. which the President compared to the pains in angina pectoris. These pains were subsequently believed to have been ramed by the rupture of the anemismal sac of one of the splenic arteries, the coat of which had been injured by the bullet in its comrse. This attack of pain was followed by others at intervals of six to twelre hours. which were muloubtedly due to the progressive disisection, at irregular intervals, of the blood into the surrounding tissue, until finally it burst into the abdominal carity. On September 1 sth another chill occurred, followed by a febrile rise. At 8 A.M. on September 19 th the President's pulse was fiust and feeble; lis temperature was loc F.. and all the conditions mnfaromable. In half an hour afterward there was still another ehill, followed by febrile rise. It $\&$ r.x. on Siptember 1?th the Presilent's pulse was still fast and fienble. temperature being 108. $5^{\circ} \mathrm{F}$. During the periods of rhill and ferer he was more or less unconscions. At 10.10 P.M. the President sank into an unconscions and dring conditims. and expired twenty-five mimutes later. The brave and lerenic: sufferer. the Sation's patient. for whom all had labored o cherdully and moneasingly, had passed away.

'The post-mortem examination was made the following afternoon alt $t$ orlock. It was necessary to determine the exact track of the ball and the parts involved; also, to ascertain the 
immediate cause of death. The autops was performed by Dr. D. S. Lamb, assisted by Dr. J. J. Woodward.

Record of the post-mortem examination of the body of I'resident Jumes A. Garfield, made september 20,1881 , commencing at 4.30 1.m. e eighteen hours after death, at Francklyn Cottage, Elberon, New Jerse'y.

Behind the right kidney, after the removal of that orwan from the body, the dilated track of the bullet was dissected into. It was fonnd that from the point at which it haw fractured the right eleventlo rih (three and one-half inches to the right of the vertelual spine). the missile had gone to the left, olliquely forward, passing through the hory of the first lumbar verteha and lorging in the adipose conneetive tissue immediately below the lower horder of the pancreas, about two and onehalf inches to the left of the spinal colmm, and behind the peritonemm. It had hecome completely encysted.

The track of the bullet hetween the proint at which it had fractured the eleventh rils and that at which it had antered the first hmmar rer. tebra was considerably dilated, and the pus had burrowed downarit through the adipose tissue behind the right limner, and thence fomm its way betreen the peritonem and the right iliac fitscia, making a de-eending chamnel which extended ahmost to the groin. The andipose tisme hehind the kidney, in the vicinity of this descending channel, was muld thiekened and condensed by inflammation. In the (hammel, which was found almost free from pus, lay the flexible catheter introlucenl into the wombl at the commencement of the antopsy ; its extremity wat found doubled upon itself, immediately beneath the peritonem, reponing non the iliac fascia, where the chammel was dilated into al ponclu of comsirlerable size. This long, descending elanmel, now deanly saen to hire been caused by the burrowing of puts from the womml, was supposed, during life, to have been the comrse of the bullet.

The last dorsal, together with the first and secomb lombar vertebre, and the twelfth rib were then removed from the body for more thoromen examination.

When this examination was made. it was foumd that the hullet had penetrated the first lumbar vertelsa in the npler part of the right sille of its body. 'The aperture, by which it entered, involved the intervertebral cartilage next above, and was sitnated just below and anterior to the intervertebral foramen, from whieh its upper margin was alwut onefourth of an inch distant Passing obliquely to the left, and forward

1 The general eondition found at the autopsy is omitted, only the portion referable to the wound being copied. 
timough the upper part of the boly of the first lumbar vertebra, the bullet emerged hy an aperture, the centre of which was about one-half inch to the left of the median line, and which also involved the interrertebral cartilage next above. The cancellated tissne of the body of the first lumbar vertebra was very much comminuted, and the fragments somewhat displaced. Several deep lissures extended from the track of the bullet into the lower jart of the body of the twelfh dorsal rertehra. Others extended through the first lumbar vertebra into the intervertebral cartilage between it and the second humbar vertebra. Both this cartilage and that next above were partly destroyed by ulceration. A number of minute fragments from the fractured lumbar vertebra had been driven into the adjacent soft parts.

It was further found that the right twelfth rib also was fractured at a point one and one-fourth inches to the right of the transverse proeess of the twelth dorsal vertebra; this injury had not been recognized during life.

On siwing throngh the vertebra, a little to the right of the merlian line, it was found that the spinal camal was not involved by the track of the ball. The spinal cord, and other contents of this portion of the spinal canal. presented no abnormal appearances. 'The rest of the spinal corrl was not eximined.

Beyond the first lumbar vertebra the bullet continued to go to the left, passing hehind the pancreas to the point where it was found. Here it was enreloped in a firm cyst of comnective tissne, which contained, besicles the hall, a minute quantity of inspissated, somewhat cheesy pus, which formed a thin layer over a portion of the surface of the lead. There was also a black shred adherent to a part of the cyst-wall, which prover, on microscopical examination, to be the remains of a blood-elot. For alwot an inch from this eyst, the track of the ball behind the pancreas was tompletely obliterated hy the healing process. Thence, as far backwarl as the body of the first lombar vertebra, the track was filled with coagulated blood, which extended on the left in to an irregular space rent in the aljoining allipose tissue behind the peritonenm and above the fancreas. 'The blood hat worked its way to the left, hursting finally through the peritonem behind the spleen into the aixlominal carity. 'The remling of the tissues by the extrarasation of this blood was unfoubterly the cause of the paroxysus of pain which oceured a short time hetore leath.

'l'his mass of coagulated blood was of irregular form, and nearly as larese as a man's fist. It could be distinctly seen from in front through the beritonem, after its site behind the greater curvature of the stomach had been exposed by the dissection of the greater omentum 
from the stomach, and especially after some delicate alhesions between the stomach and the part of the peritomem covering the hoor-mass had been broken down by the fingers. From the rehations of the mass, as thus seen, it was believed that the hamorrhage hat proceeded from one of the mesenteric arteries, hut, as it was clear that a minute dissection would be required to determine the particular branch inrolved, it was agreed that the infiltrated tissues and the adjoining soft pants should be preserver for subsequent stuly.

On the examination and dissection, made in accorlance with this agreement, it was found that the fatal hemorrhage proceeled from a rent, nearly fonr-tenths of an inch long, in the main trunk of the splenie artery, two and one-half inches to the left of the colitc axis. This rent must have occurred at least sereral days before deatl, since the ererted edges in the slit in the vessel were united by firm adhesions to the sur: rounding connective tissue, thus forming an almost continnous wall bounding the aljoining portion of the blool-clot. Moreover, the periplleral portion of the elot in this vicinity was disposed in pretty firm concentric layers. It was further found that the cyst below the lower margin of the pancreas, in which the hnllet was fonmd, was situated three and one-half inches to the left of the coeliac axis.

Besiles the mass of coagulated hoor just describer, another, about the size of a walnut, was fomm in the grater omentmm, near the splenic extremity of the stomach. 'The commmication, if any, between this and the larger hemorrhagic mass conkl not be makle ont.

The surgeons assisting at the antopsy were munimomsly of the opinion that, on reviewing the history of the ease in commection with the antopsy, it is quite evilent that the different supmrating surfaces, and especially the fractured, spongy tissue of the vertebra, furnish a sufticient explanation of the septic conditions which existed during life.

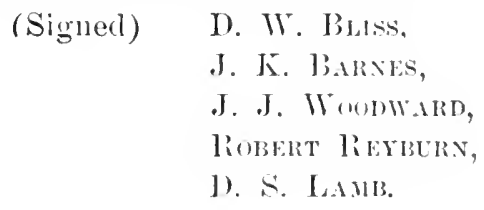

There never was a case in the history of medical literature whose entire course was followed so anxiously, so closely, and so intelligently, by so many milions of perple. 'The surgical aspects of the case became so familiar to the millions who scanned the daily bulletins and read the daily papers that many surgical methods and many technical terms which hitherto 
hat been the exchusive property of the profession, became perfectly fimiliar to all. Undoubtedly, before the summer was over, the public were able to discuss the case from its purely medical aspect with the greatest thoroughness and intelligence.

Ol course, with so many minds studying the same subject, enlancel by the natural obscurity of the case, considerable discussion arose as to the proper treatment. Sensational newspaper-writers. anxious to boom the circulation of their journals, attacked the judgment of the physicians; medical men, eager for notoriety, worked out hypothetical cases in the privacy of their offices, and, fitting the President's condition to their theories, ru-her into print. To the credit of the public and physicians in chare of the case, it must be said, however, that the great malss of the public and the majority of newspapers accepted the treatment as correct. as it was ontlined in the daily bulletins.

Through all this storm of excitement, criticism, doubt, and respon-ibility. the little coterie of physicians in charge of the President's case maintained a dignified silence. It was encomaging to see that they were not driven from the decision which they had reached, by this great storm which raged thronghout the American world. In the sober light of afterjudgment it was unirersally conceded, not only by the nation as a whole, hut by the better (lass of the press and the entire medical prolession, that the ase had been perfectly treated, and that nothing lakd been left undone, either in the way of meeting existing conditions or anticipating possible contingencies.

The qurestions to be discussed in deciding upon the correctness of the treatment are as follow:-

1. Wres the nermol necesserit!l " moital one? This question wal, of conrse. of the most rital importance, in which all

1 It is curious to note that in the thonsands of newspaper clippingrs on Dr. Agnew's life, publishel at the tine of his death, there were but two unfarorable notices found. One

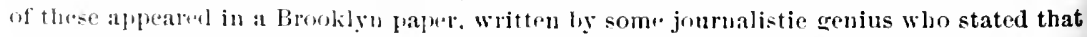
lu. linew all abunt the combition of the vertebrat of Presilent Garfield, as revealed at the autury, lone before he diel. The other appearol in a journal publisbed in Salt Lake City umler llowmon manarement. It stated that Dr. Agnew put President Garfield under a course of treatment that would liare killed a well mau. 
considerations as to diagnosis, treatment, and the precise mode of death would be, in comparison, of secondary moment, although, in the consideration of the attending phrsicians, these points were just as material. In the event of the plea of malpractice being offered in the Guitean trial, this would have been the principal question to have been determined, from a legal stand-point. In this connection, the disconsion in the North American Review for December, 1881, by four leading medical anthorities of this country,-Dr. Jolin Ashhurst. Jr., Dr. J. Marion Sims, Dr. John T. I. Iodgen, and Dr. William A. Hammond,-is to the point.

Undoubtedly, the strongest arguments on both siles of the case are presented in this symposium. The only one of the four to take the ground that the wound in the verteluan. in the case of President Garfield, was not necessurily mortal was 1)r. William A. Ifammond. Dr. Ilammond rested this proposition entirely on a few quotations from surgical literature, from which he endearored to show that pationts may recoser form gumblot wounds of the vertebre. The quotations made by him are garbled in the extreme; portions of the statements being qunted, qualifying or explanatory portions being left ont. and condelsions being reached wholly unwrianted by the guotations selected. Further, in such rases as are cited no attempt was made to prove their similarity in any essential particular to the case of President Garficld. It was a matter of surprise to many who did not linow I)r. I Iammonel that he should hare dared to risk the positive assertion that death was not inevitable from such a wound, based on such insufliedent and deceptive dat til.

On the other hand, the other three anthorities, l)rs. John Ashhurst, Jr., J. Marion Sims, and John 'T' I Ioderen. angerel that the President's wound was neecrialyly a mortal one. 'The real status of the literature of surerery on the subject was finlly expressed by 1)r. J. Marion Sims, when he wrote that "our whole medical literature does not rontain "s single well-anthenticated case of recovery from such a wound." 
2. Did the position of the President and the assassin at the time of the shooting offer any clue as to the track of the bullet? It was overlooked by many critics of the treatment that this point was carefully considered at the time of the shooting and subsequently. The fact that the ball, on entering the body, struck the elerenth rib and was deflected at almost a right angle from its original course, immediately on entering the body, together with its zigzag course later,-revealed at the autopsy,showed that there was no satisfactory data to be obtained from this source.

3. Conld the ball have been detected and located by the use of probes? The track of the bullet as seen at the autopsy showed the wisdom of the physicians in their refusal to persist in probing. The ball, after fracturing the eleventh rib, was deflected downward, comminuting the twelfth rib; it then passed through the fibres of the psoas magnus muscle, which run longitudinally; these fibres undoubtedly closed soon after the passage of the ball, eliminating all possibility of following its course, so that the track of the ball disappeared within a short distance from the skin. If the probing had been persisted in, undoubtedly the aorta, the thoracic duct, or the rena cava, would have been in danger of being ruptured, for the ressels lay, with their delicate walls, in the direct course of the probe; such an accident meant instant death. If this grreater danger had been aroided, the foramen opening into the uninjured spinal canal might have been entered, with unfortumate results. It would have been impossible to have reached the opening through the body of the vertebra; even if it had been reached, the ball would have lain undiscovered on the other side of the spine. Persistent attempts at probing would have lilled the President at once, without possessing the slightest chance of revealing the position of the ball. If the ball had been found it would have made no difference in the result, for it had become encysted, as was expected, and was doing no harm. 
4. Were there any symptoms which pointed to the injury in the spinal column? Many readers, confused by the similarity of the words "spinal cord" and "spinal column," imagrined that the spinal cord had been injured. On the contrary, the autopsy revealed the fact that it was minjured, the spinal column, or its bony support, being the portion fractured by the ball in its passage. If the spinal cord had been injured, it would hare been discovered, but no positive symptoms existed of the injury to the rertebra; in fact, beyond a few tingling sensations and the hyperesthesia felt on the right side of the body below the waist, there were no nerrous symptoms at all. To have based a diagnosis of fracture of the vertebra on such data as this would have been poor surgery, for these slight symptoms are not at all characteristic of such an accident. The possibility of this injury had been considered, however, by the consultants at their first meeting, but there was a total absence of data on which to base such a belief. The probe, as has been shown, conld not have rerealed its existence. The vomiting and collapse, which were extreme, are symptoms of shock, and are common to that condition. Their existence, to an extreme degree, suggested the possibility of injury of some important viscera, but all other traces of such a calamity were absent during the entire course of the case. All those persons who revealed the fact-the majority of then after the autopsy-that they had diagnosed this fracture of the vertebra based thcir opinions on data too weak to be anything more than mere guesswork.

5. Should an exploratory operation hare been performed to seurch for the bullet and to vereal the condition of the wounded parts? From a study of the answers to the previous questions, it can be seen that there was no clue as to the direction in which such an exploration should have been made. As was believed at the outset, it would lave added greater peril to the case, without improving in any way the prospects of the wounded President.

Undoubtedly, the fatal issue of the case was due to this 
injury of the vertebra. The septicemia, or blood-poisoning, which appented can be traced to this source. The injury of the cancellated structure of bone is peculiarly prone to be followed by the production of blood-poisoning. It was a matter of surprive to the public to learn that such is the case; it is due to the finct that the open venous sinuses in the cancellated tissue of bone, bathred in ichorous pus, are most laworable conditions for absorption of this poison and the production of this state.

'There was no criticism made at any time by any one as to the numing and feceling and the general hygienic treatment of the patient. 'This was acknowledged by all to have been superb. undoubtedly prolonging the President's life for many weks. It is certain that no improvement coukd have been make in the troatment, had the injury to the vertebra been linown. 'The treatment throughont was in accord with the rules of the strictest antiseptic surerger. Dr. Hammond wrote in the article (puoted: " I desire to express my profound admiration for the fidelity. derotion, and assiduity displayed by the attending and ronsulting sllocons. Rarely hals any man, whether of hish or low dewere, hat a more laborions and dutiful body of medical and suregieal attendants than had President Garfield, and I belicre that in no other country in the world conlel such entipe abnegation of solf as they exhibited have been obtained firom physicjans and sureons in attendance on prince or potentatte." J)r. Inammond attacked only the sureical treatment of the first fintrecight lomes as not being in accordance with surencial prerepts. 'Tluis was before the consultants were called in; hut an they concoured in the correctness of this treatment, its repmeribility fell on them also.

It was thomelit probable that the bullet had been deflected into the right iliar, foseal but this belief was not held unreservnlly hy the attending phyicians, and by Dr. Agnew it was lexanded ats a mere possibility. As to the comse of the ball, it was not an erol of diagnosis, but simply an absence of diagnosis, Such conditions are every-day occurrences in surgery. 
As to the immediate cause of death, it was believed by Dr. Hammond, in the article just quoted, that it was due to heartthrombus, and that the pus-sac was the sole cause of the bloodpoisoning. It was acknowledged by atl, however, excepting this author, that the principal source of septic infection was the wound in the lumbar vertebra. and that death was due to the rupture of the aneurismal sac of the splenic artery, either from its injury by the bullet in its course or from the extension of the process of inflammation to the artery from the track of the ball. Dr. Hammond claimed the possibility of the rupture of the aneurismal sac by the injection of the embalmer, overlooking the fact, pointed ont to him by Dr. William Hunt, in the New York Hedical Record (November 26, 1881), that the blood in the abdominal cavity could not have been pushed out of the splenic artery by the embalming-fluid, for the reason that there is nothing in arteries which can be pushed out after death, these channels being empty at this time. Moreorer, the arrangement of the clot in concentric layers showed that the hemorrhage must have occurred during life.

These statements and opinions of Dr. I Iammond are suppposed to represent the strong side of criticism as to the management of the President's case. 'They ane based on data pitifully weak, and they fatl entirely short of proving that any essential difference in the mode of treatment would have resulted any more farorably. Dr. Itammond did not claim that the ball could have been found, much less aletricted, or that any system of drainage of the wound in the vertebla contel hare heen established, thus remoring the principal if not the sole calnse of the blood-poisoning, and posibly presenting that deprared general condition of the system which superinduced the rupture of the aneurism. On the other hand, the other three physicians quoted abore frankly acknowledged as follows: I)r. John Ashhurst, Jr.- "Looking at the whole case from beginning to end, I do not see that the treatment could hatve been altered in any way to the advantage of the illustrious pationt; nothing was done that 
should have been omitted, and nothing was left undone that conld possibly have been of benefit." 1)r. J. Marion Sims"The President's surgeons did all that men could do, all that the present state of science would permit, and all that could lave been done even if they had at first ascertained the course and direction of the ball. Our whole medical literature does not contain a single well-authenticated case of recovery from such a wound. He had not the least chance of recovery under any circumstances or any treatment." Dr. John T. Hodgen"In reviewing the history of the case of President Garfield, I can find no reason for adverse criticism of any part of the management."

So universally was the correctness of the treatment of President Garfield conceded, that the legal comsel defending the assassin Guitean did not attempt to use this point in his defonse, resting instead on a claim of insanity. Guiteau himself, however, alternated between an expressed belief that the doctors had liilled the l'resident and that that official had been removed by divine command; he was unable, however, to explain the discrepancy existing between these two beliefs. The first belief was brought out at the commencement of his trial in the following incidcut. Colonel Rockwell had been placed on the witnesi-stand, by the prosecution, to prove the shooting of the Presilent. After a number of questions had been asked lim. the commsel for Guitean arose, and, claiming that the questions asked were irrolevant, sald, " We do not deny, your honor, the killing of the l'esident." Guitean immediately sprang to his foret and exclaimed, "Yes, we do, your honor; we admit the sleoting of the President,- - not the killing."

"The remartiable trial, subsequent conviction, and execution of Guitean hate become a portion of American history.

Throngle the terrible ordeal and frightful monotony of cighty days of prolonged suffering and of incessant watching, the wounded President bore all with incredible patience and the most Christian-like fortitude. He constantly maintained a 
cheerful aspect; his words and actions were always courageous, although undoubtedly he was deeply impressed with the probable issue of his case. When he asked Dr. Bliss at the outset, if there was any chance for recovery, Dr. Bliss replied: "Mr. President, your injury is formidable. In my judgment, however, you have a chance for recovery." The President replied, with a cheerful smile: "Well, Doctor, we will take that chance." This was his attitude through his entire illuess. In everything he aided the physicians and nurses in their difficult work without murmuring or faltering.

The history of this famous case and the course of treatment are given and explained with a moderate degree of detail, because to a large portion of the American public, outside of Philadelphia and its vicinity, it was the chief means of acquaintanceship with Dr. Agnew's name. It has been stated that Dr. Agnew's connection with the Garficld case was the circumstance which made him famous. In regard to a portion of the laity, this is undoubtedly true, for the environments of a phrsicinn's life are such that there is no way for him to become known nationally except by comnection with some such incident. 'The degree of celebrity attained by Dr. Agnew from his comnection with this case cannot be under-estimated. This was the beginning of that acquaintanceship with his character and career which have, therefore, become known until now there is probably not a hamlet in the United States in which a fair lnowledge of his carecr and a good estimate of his character and services are not possessed by the intelligent citizen. Ilis connection with this case was so indissoluble that it was seen even in the streets of his own city, where his fame and arhievements were no new thing; it was a common experience for patients sitting in his office to hear passers-by say something" of this purport: "Here is Dr. Agnew's office,- - lon't you remember; he was Garfichd's surgeon?"

At the same time, it is not firir to Dr. Innew to say that it was this connection which made him a famous man. The 
medical profession of the world had regarded him as the leading surgical anthority in America and probably the most expert operator in the world, long before he was consulted by Dr. Bliss. 1)r. Bliss, in his selection of the President's chief consultant, simply voiced the general opinion of the medical profession. Certainly there was no educated phrsician who had not been, previonsly, familiar with Dr. Agnew's career and teaching.

While the Garfield case made Dr. Agnew better known to the general publie, at the same time he would have been as much beloved and as well known to the larger portion of the intelligent American world without it. That this is true is shown by the tremendous variety of locations from which his patients came. It was a common experience to find clustered in his waiting-room patients from far-distant points. For example. one of his friends remembers to hare seen, waiting to see Dr. Annew at one time, a patient from San Francisco, another from New Orleans, and a third from Boston. They came from crerywhere, even as far as from India and different portions of Europe.

The strain and amoyance caused by this case cal the attending phyicians an nerer be known. Looking simply at one phase of it, it is hard for any one to ralize the espionage under which ach physician rested, and the constant pressure lorought to bear by persons secking information as to the President's conclition. Not only was Ind. Agnew constantly besieged hy visitors. but even his scrants were not exempt from interriews. It was the (nlstom for I)r. Agnew and Dr. Hamilton to (2) alternately to Washington or to Elberon certain days in the week. Of 'ontrse, this had a bad effect mon Dr. Agnew's practire, as it malle him unable to attend to much of his work, and also made him uncertain in his town visits; and, on the other hand, many patients from this cause came to him simply out of curiosity. Iis limited time in town caused his wating-room to be croweded always. Sot only was the room full, but the windows, the hall-way, steps, and frequently the 
strect in front. Often some waiting patient, whose time hung heavily on his hands, would count from seventy to one hundred people waiting to see Dr. Agnew. On such or(alsions 1)r. Agnew never hurried over the patients; he examined cach case that presented itself as carefully as if it were the only one. This was always his custom,-he never hurred a patient ont of his office. When his time was exhausted. he would step into his waiting-room and say: "I have seen all that I can to-rlay; those who still care to see me will please come at my next office hours."

No one can ever know the terible, protracted strain on all the physicians in this case. The letters received by Dr. Agnew formed a part of this ordeal. Frequently a stack of letters a foot high would be received in one day, telling lim what to do, what not to do, suggesting remedies, threatening, inquisitive, and impudent.

One unpleasant phase of the illness of the President was the eagerness with which certain unserupulous persons used the condition of the President as a means to better their financial condition. So alarming was the condition of the President from the outset, and so anxious was the publie to aseertain his condition, that newspapers issued editions at night. 'Two or three stout-lunged fellows with great rolls of papers meler their arms would start round some quict street in the small hours of the night, and by their shoutings would awalien nearly the entire block. The half-awake citizen, hearing a jumble in the street, and catching a fragmentary word here and there, naturally imagined that some fresh calamity had befallen the nation. IIe would purchase the paper, and by the time he had examined it, only to find that it contained nothing of special importance, the energetic newsboy would be ont of reach.

When the Committee sent by (ongress to obtain from ])r. Agnew his bill for attending the P'resident anme to Philadelphia to his office, Dr. Agnew said: " (xentlemen, I present no bill for my attendance to President Garticle. I gave my services 
frecly and gratuitously:" He persevered in his determination to present no bill, despite the adrice and solicitation of the Committee who had charge of the arrangements.

Undoubtedly the attendance on this case, and the subsequent treatment which he received, killed Dr. Bliss. During the eighty days which the President lived, after receiving his injury, Or. Bliss' attention was unceasing. The strain, both mental and physical, which he endured, so broke down his health that he was unable to resume practice for a long time afterward. 'The terrible ordeal through which he had passed, the attacks made upon him, and the accusations both as to his profesional and moral abilities, shattered him completely. He fommd, in consequence, that his practice had been largely scatterel. and he realized that he was not cqual, physically, to the cffort of renining it. In consequence, his income, which had areraged $\$ 20,000$ a year before his assumption of the President's case, fell to almost nothing. 'The last blow which he received was the niggarlly manner in which he was treated by the goremment. His claim for $\$ 25,000$ for his attenclance on the President, which was a rery modest sum, under the circumstances. Was cut down. and he received $\$ 6500$. He never recovered from this last action, which he regarded in the light of an insult, and his death occurred not long after. Although 1)r. Annew would present no bill. his claim was made equal to that of Dr. IIamilton's, \$15,000), while cach of the other attencline phycicians put in a raim for $\$ 10,000$. Congress "plpopriated the sum of $\$ 35.000$, with which to pay the repenses of the (ase. Is has been said, 1)r. Bliss received Sif(i.)(0); J)rs. Agnew and Hamilton, each, \$5000); Dr. Reybum, Sto(0); the nurses, 1)rs. Boynton and Edson, received $\$ 4000$ ancl sis 3000 , respectively.

After paring these sums to the physicians in attendance, the remainder of the money which Congress had roted to the physicians was retumed to the Treasiny by the Board of Audit, although they had been instructed to distribute the whole 
amount. Of the coterie of physicians who attended President Garfield, Dr. Robert Reyburn is the only survivor. This experience of Dr. Bliss with the Garfield case is not an unusual one in medicine. It is a good commentary on the value of publicity to a physician.

The position which Dr. Agnew held in the Garfield case was that of chief consulting surgeon. He was recognized by the patient, by the attending physicians, and by the public as the man to whose judgment the greatest importance was attached. His selection for this position was spontaneous and undisputed, and he performed all the operations which were done, exhibiting his usual dexterity and skill. It has been said that when Dr. Bliss handed the keen-bladed knife to Dr. Agnew the eyes of the Nation were upon that blade; and yet, in no way did the distinguished surgeon show that there was any unusual stress on his nerves, or that he was affected by the unusual importance of the situation.

In a recent letter of condolence from Mrs. Garfield, she places the following estimate upon 1)r. Agnew's servires at the bedside of her distinguished husband: "Dr. Ignew's faithful attendance at the President's bedside through his days of :uffering won our decpest gratitude and our entire confidence in his distinguished ability as physician and surgeon. Ilis presence was a constant source of encouragement and comfort to General Garfield, and his ever-entertaining discourse tided $\mathrm{my}$ husband over many dark hours."

Dr. Agnew never took a hopeful view of the President's case. He was most eager. of course. to hope that a farorable issue would follow, but he never allowed himself to be deceived by delusive beliefs. He knew that deep-seated. undiscoverable mischief was at work. One day at Elberon Dr. Bliss, in speaking of the President's case. said that the world wonld soon see the most wonderful cure in medical history. The same erening, in conversation with Dr. Agnew. some one gare expression to the enthusiasm of Dr. Bliss and the joy the country would feel 
at the rescue of the stricken President. Dr. Agnew listened attentively, and said, in his quiet way: "I pray every hour for this consummation; but when I first saw the President I felt that death lad claimed him. I would be the happiest man in Elberon to helieve as Dr. Bliss does. The President may live the day out. and possibly to-morrow; but he camnot live a week." Gartield died the next day.

This case of President Garfield made a difficult and mpleasint task for his attending surgeons. There was apparently to the public but small chance to exercise great diagnostic judgment or operative skill. 'The course laid ont by the consultants required but a few operations, which were only moderatcly difficult in their performance, and not especially dangerous. This lack of opportunity for the performance of some brilliunt surgical operation by which, after taking great risks, the President could have been restored to health, was deplored by many. On the contrary. no better illustration exists, in his whole carcer, of the character of Dr. Agnew than that, under the stres of ontside influence, he did not swerre a fraction of an inch from his better judgment and attempt a brilliant exploratory operation instead of adopting the course he did. He did whilt he felt to be his duty,-what his judgment dictated,withont regard to its effect on the outside world. He had no desire to kindle admiration or create excitement.

'The ereat importance of the service rendered by Dr. Agnew in the "ate of President Garfield can scarcely be appreciated, after it was accomplished. The credit of this is due largely to 1)r. Inncw. because, while all the surgeons were unanimous in their conceptions of the treatment of the case, yet, undoubtefly. had 1)r. Ignew adrocated another plan of treatment, it woild have been followed out. The President's assassination threw the whole country into a state of the greatest excitement, alarm. and apprehension. If the President had died at once. there is no telling what miglit have happened. Especial apprehension was felt in regard to the line of succession 
to the Presidency, in case anything should happen to the VicePresident.

This contingency had never been provided for by the founders of the government. It was a peculiarly dangerous period, especially on account of the numerous insane persons throughout the country who are on the outlook for such orasions, and who always come forward at such times, producing the most calamitons consequences. If the President hald died at once, or soon after the shooting, probably the excitement, publicity, and apprehension would have brought forward a Guitean for President Arthur. The President being kept alire, all feelings of uneasiness and resentment passed away. The government had an opportunity to arrange its worlings, and the whole country subsided into a calmer mood. This work of keeping a mortally wounded man alive for nearly thee months was most stupendous in its accomplishment and in its results for the country at large.

Moreover, its value to President and Mrs. Garfield should not be overlooked. It gave opportunity for the settling of the business of the President and the arrangement of his spiritual affairs, which was most comforting to the living and the dying. 


\section{CHAPTER XI.}

\section{Dr. Agnew's Hoye-Life. ${ }^{1}$}

So many know of Agnew the surgeon, and so few know of Agnew the man! This was mfortunate, for it was under his own roof-tree, and in the midst of his own little family that the most beautiful side of his character was shown. It was my privilege to have lived with this good man for a period of fifteen years. We were not a large family; there were only four of us,-Dr. and Mrs. Agnew, and their two nieces, Miss Ella P. Irwin and myself. This number formed, in Dr. Agnew's estimation. a perfect family; four at home, and in travel being a complete number.

In their earlier life in Philadelphia Dr. and Mrs. Agnew had been in the habit of spending their summers in travel, or in resting at some quiet sea-side revort, near enough to the city to allow him to go there daily. For sereral years they had a cottage at Atlantic (ity, being among the first to realize the benefits and disadvantages of that city by the sea.

In 187.2 Dr. and Mrs. Agnew decided to go abroad; they sailed in June and returned in September. This was the only time Dr. Agnew ever crossed the ocean. He was alwars hoping for a time to come when he might throw off every care and talie a more satisfactory European trip; for, unfortmately, this trip was saddened by the sudden and serious illness of Mrs. Agnew, She was taken sick in Genera, Switzerland, where she lay in a critical condition for some time. When she had improved sufficiently to be moved, she was taken to Paris, where Mr. Joln Russell Young, then correspondent for the L.r. Gor Heruld, lindly placed his home at her disposal.

While at Geneva, Dr. Agnew performed several operations; for he could not, even on a pleasure-trip, leare his work

1 This chapter was written by Margaret Agnew Adams. 
wholly behind lim. In consequence of Mrs. Agnew's illness, Dr. Agnew was unable to visit many of the European hospitals or to form the acquintance of the medical men whom it would have becn a mutual pleasure to have met.

Yet, when Dr. Agnew returned from Europe, he came home with a much higher respect for American medicine and surgery. He said: "Here we fecl that the welfare of the patient is our first and highest duty. Abroad, especially upon the Continent, this scems to be a secondary matter. There they are more anxious to find out what is the matter with the patient, and look more eagerly for an autopsy than for a recovery."

In 1875 they spent the summer at Atlantic City, where Mrs. Agnew contracted a severe attack of typhoid ferer, following which for eiglit months she horered between life and death. By the summer of 1876 she had sufficiently recovered to be taken to the country, and she was movert to Bryn Mawr. 'They had learned so to dread the bad drainage of hotels and sea-side resorts and the exposure incident to travel, thit they determined to purchase a permanent country home, in which they could spend the summer.

Feeling well satisfied with the purity of the air in the vicinity of Bryn Mawr, and its nearness to the eity, I)r. Annew, in the fall of 1876 , purchased a number of acres at IInverford College Station, on the line of the Pennsylrania Railroad, one mile cast of Bryn Mawr.

He was one of the pionece settlers in this region, which has since become so popular and fashionable amoner rich Philadelphians. Here he built his comutry home, ". Wyndrift," in which he spent, subsequently, so many happy loms. A portion of his property he disposed of the following summer, to his intimate friend, Mr. Crawforel Armold.

This Haverford home was to him the resting gromel for the few leisure hours which he took from his work. Always an extremely early riser, here he arose at 6 o'clock in the 
morning, bathed, slaved, and breakfasted by 7 o'clock, and walked to the station, a distance of about three squares, and took the 7.11 A.M. train for the eity; this enabled him to be in his office by 10 minutes of 8 o'clock each morning. In the summer-time he had no afternoon office-hour, remaining in lis office until half-past 11 or 12 o'clock; then he ate a light lunch. consisting invariably of cream-toast, milk, and a softboiled egr. These articles of food constituted his principal diet, for he was always most abstemious with food and drink. Then he saw the patients who required visiting for the day, always planning, if possible, to return home about 5 o'clock in the afternoon.

He usually sat, on his way to town, with his friend Dr. Walter F. Atlee, whose station was sereral miles west of Haverford, thus giving him greater advantage in the selection of a seat. The seat which they generally occupied would not have been considered desimable by most people; it was the one at the extreme firont of the car, just back of the door, but it suited them, and, being conservative men, they did not change after once havine made their selection. Often they would spend the short half-hour in conversation-sometimes carnest, serious tallis; again, merry tales and ancedotes. Indeed, 1)r. Atlee proved to be such a spartiling ruconteur that it became quite the thing for us to look forward to an evening dinner-hour, when our dear doctor would sooner or later besin, with a smile of pleased recollection, "Atlee was telling me to-day,"- - and then would follow "Atleess latest."

Oliten, however, the thirty minutes were spent in reading. 1)r. Agnew was never without a book, generally a volume similar in size and style to the series of the "Little Classics."

When Dr. Agnew could come ont to lis country place he left behind him all the worries and anxieties of his busy profensional life. Probably it required a risit to Haverford to see him in his pleasantest, 'easiest moods. Here he dropped all thought of hurry or business, and lost that reticence which was 
somewhat a characteristic of his work, with those with whom he was not fully acquainted.

He made a most charming host; he was affability and hospitality itself, and he possessed that rare faculty of making his guest quickly and thoroughly at home. Many people, ared by his presence and reputation, have often said that they were afraid to umbend before him; but here he placed himserf in the mood of all those with whom he came in contact. He was a brilliant conversationalist, and possessed that rare ficulty of bringing out in those around him their own ideas and thoughts. He was able to talk with every one who rame to his house on their own daily work in a smprisingly fimiliar way, and he was that rarest of rare beings, - a sympathetic listener. Quictly adding a word here and there, eren the most diffident school-girl was at ease with him.

He loved to entertain his friends. Many persons imagined him to be stiff, dignified, and devoid of humor. On the contrasy, while thoroughly dignified, he never inpressed any one, with whom he was folly acquainted, with any severity of manner, and his sense of humor and of the ridiculous was rery marlied. He would see instantly any ridiculons situation or incident, and could tell a story with the greatest charness and force.

No one approved of pure fun or humor more thoroughly than Dr. Agnew; but he was sensitively arerse to gossip,even so-called immocent gossip he abhorred; and I have soen him look pained and embarrassed white within ear-shot of idle chatterers whom he conld not rebuke. In his own lamily. he simply would not brook anything which even savored of gossip, saying always, "If you cammot speale well of a perion, it is best to saly" nothing."

When Dr, and Mrs. Agnew built their country home, it was with the intention of spending six months of the ycar there, continuously, Dr. Agnew intendinge to take a week or two off in the summer; but he soon found that Ifarerford was not the haven of rest he had desired, for his paticuts sought him 
out even there. So it naturally came abont that every summer 1)r. Agnew found it necessary, in order to obtain any rest at all, to takic a short outing, lasting regularly from ten days to two weeks, and, although no one enjoyed traveling more than he, he allowed himsell only one of these during the year. Short as these trips were, much pleasure was crowded into them. We usually started on our little jaunt about the second or third week of August.

These outings were always most pleasant to us and most eagerly looked forward to; for at these times we had our dear doctor all to ourselves, while at home his whole time belonged almost exchusively to the ailing public. A doctor's life is trying not to himself alone; his whole family is called upon to make many sacrifices. Indeed, a doctor's houschold is perhaps more thoroughly identified with his work than that of any other proferional man. Of social life a successful doctor has almost nothing. IIow many, many times, when we have been all ready for a dinner or reception, messages have come calling our doctor away! We were never sure of a quict half-hour with him, even at moal-time.

When away on one of these trips, he enjoyed nothing botter than a good novel. The class of stories which he read were such books as "Loma Doone," the tales of Scott, "Rab and Ilis Friends," "Uncle Remus," cte.; he was particularly fond of dialect tales. especially such Scotch and negro stories as illustrated the traits, customs, or thoughts of their heroes.

Many persons at such times noted with surprise how difficult it wals to get him to his meals when he was immersed in the cxcitements of a well-told story. One of the last novels he leanl was "Kidnapped." by Robert Louis Sterenson. He entreal inte its exciting vicissitudes with all the enthusiasm and delinglit of a boy.

It was always a great pleasure to travel with him; lie liad fricnds everyhere, and every one was anxions, even eager, to serve him. IIptel proprietors instinctively gave him the best 
rooms; even the porters on the trains in some mysterious way knew him.

There was some subtle influence about him, which made even strangers rie with each other to increase his comfort and do him homage. Perhaps it was the uncommon malie-up of the man; his splendid physique and general ruggedness, softened by the crown of soft, white hair, and the mildness of very rlear blue eyes. Dr. Agnew, like his father and uncles before him, was like unto the sons of Anak for goodly height and manly proportions. He stood six feet one inch in his stockings.

As he grew older, he grew more imposing in appearance. His hair, which was always light, whitened in his early manhood; in his early years he wore a finl beard, but later in life discarded everything except a moustache, which he allowed to grow rather long. There was a great deal of character in his hands; they were strong, white, and wonderfully supple, and beautifully cared for. In his dress, Dr. Agnew was plain to a marked degree, gencrally wearing a black frock-coat, black vest, and black, or sometimes gray trousers. The only latitude he allowed himself in dress was in the selcetion of neck-ties. Although usually wearing a black four-in-hand tic, the supply of which was always kept full by a patient, yet he sometimes would appear in a gamet satin bow-tie.

In the fall of $1886 \mathrm{Dr}$. R. J. Levis determined to soll his residence at 1601 Walnut Strect. D), Annew, who had lived at 1611 Chestmut Street for almost twenty-one yours, and who had been for some time on the lookout for a house adapted to the purposes of a plipsician, heard that the laceris houne was for sale and lost $n 0$ time in seculing it. 'This house wats rebuilt by Dr. I evis, and was especially planned for a surecons. laring its offices on Sixteenth Street, entirely sepalrate from the rest of the house and not interfering in any way with the domestic arrangements. The house has frepuently been called the "Surgeons' House," for it was orenpied originally by I)r. Edward Hartshorne, surgeon to the Pemnsylrania Hospital. 
I think sufficient emphasis has not been placed upon Dr. Agnew's magnificent constitution, which enabled him to perform the tremendous amount of work that he did. Until within the last five years of his life, he was never known to have an ache nor pain excepting an occasional attack of rheumatism. - How often, when some member of his family complained of headache, he would say, quizzically, "Headache, what is it? I have never had it in my life!"

He was one of the most pains-taking, tireless workers that ever lived, toiling steadily and patiently from early morning until far into the night. He really seemed to find recreation in work. and after doing the work of three ordinary men during the day-work of the most difficult, delicate, and nerve-trying character-lie would come home in the evening and go to his office to write with all the freshness and zest of a boy.

His fireshness and enthusiasm made him seem always young. He never gave the effect of being old, and, compared with many who were no older than himself, he seemed very youthful in his ways and thoughts. This was due partly to the fact that he adapted himself quickly and thoroughly to any improvements in moulern life as casily as he did to those in medicine. While he loved and revered the good old customs of by-gone days, he did not cling blindly to old traditions. As he said himself: "I am not one of those who believe that the old is always better than the new; that we should always hold to the traditions and methodi of the past. The past has gone into history, and can only be nseful to us in so far as it will serve to illuminate the prent and the finture."

i fropes of this routleful effect upon his intimate friends and rellives, l well remember my intense indignation when, as a yommgeris. I was asked the name of the "old white-haired sentloman who sat so fir front in the Second Church." Whitehinired, to be sure; but old-never!

Mr. Lenew's beliof in his ability as a worker in any field was always of the humblest character. He never trusted in 
his own powers, but always before an opcration asked for divine guidance during its performance. Ife carried the same humble opinion into his church-life. He was chosen four times to the eldership in his church, but each time he declined the call because he deemed himself mworthy for this sacred office.

Trained from childhood to the strictest observance of the Lord's day, Dr. Agnew rigidly upheld all the old customs in his own home. Sunday-morning breakfast was, if anything, earlier than that of the other mornings of the week. After a chapter in the Bible and a prayer for divine guidance throngh the day, the family separated, to meet again in a few hours at church. Service over, we walked quictly home and sat down to a plain dinner, for 11. Agnew was strongly opposed to "firstday feasts." After dimcr followed a happy home-hour, in which the sermon of the moming was discussed, questions in the catechism were asked and explained, and farorite hymms were sung. At 2.30 we separated again, the doctor going to visit his patients and the younger ones going to Sumdarschool. At 6 o'clock came supper, after which another chapter from the Bible and a prayer for divine protection during the hours of the night, and the doctor would spend the intervening time before evening service in reading the Bible or his favorite "Life of Guthrie"; 9.30 o'clock fomm the house closed for the night.

As a child, how I dreaded those Sundays! No Simdayschool books, no walks, no gazing out of the front winclow at the altogether too attractive dresses of other little girls! How hard, how tiresomely hard it all secmed! As T prew older, howerer, those dear Sumclays at home became to me the sweetest days of all the days of my young womanhood; and I shall always hold them in blessed memory.

Dr. Agnew nerer lad a Sunday office-hour, and nerer,

1 He observed the eustom, however, of secing patients in his oflice at 5 o'clock Sunday afternoon, whose eondition demanded attention, but who were not sick enough to be confined to the house. 
muless liept away by sone ailing one, missed the morning and erening service at the church he so dearly loved.

He was particularly attracted to clergymen, esteeming it the areatest honor and privilege to entertain them. I can see him now-the dear old man - with face all aglow, sitting on the porch of his comtry home, in close converse with his dear friends Mar. Intosh and IIoge. These men were to his later years what Beadle had been to his younger manhood. What delight he took in them! What joy it was to him to entertain them! In the days he spent with them, it seemed as though his heart were kindled afresh with the fires of youth. And with what glee would he listen to their anecdotes, and, in his quiet way. add boyish reminiscences of his own!

He was extraordinarily well acquanted with theology, and could argue on a doctrine or discuss a theological movement with the greatest rigor and comprehensiveness. He undoubtedly would have made a good minister. He could talk beantifully and simply on religions subjects, on which he felt a great courtesy toward the feehings and opinions of all. He would frequently allow points to pass in which he did not believe, simply from a desire not to wound the feelings of his guest.

'There was always a great source of affinity between members of other religions beliefs and Dr. Agnew. Although he was of the strictest ('alvin Presbyterian belief, yet he was rery tolerant of other beliefis. and formed many of his friends among people who were most diverse to him in religions opinions. Roman Catholics semed particularly attracted to him, especially members of the priesthood and sisterhood. It was no uncommon ingle to see forr or six nums sitting in his waiting-loom. He cxpresed great rympathy and admiration for the works of these crelirs: and under no circumstances would he charge them for his sorvices an! more than he did the Protestant clergy. In return. they appreciated his kinduess and skill and made him the rexipicut of many beantiful presents.

The number of presents which Dr. Agnew received was 
simply tremendons. They consisted of everything imaginable: handsome carriages, thorough-bred horses, registered cattle, watches, canes, barrels of oysters, terrapin,-in fact, everything fancy could suggest. He smoked the very best brands of cigars and cigarettes, which were always kept in stock by his admirers. Even his ice-house each winter was filled with particularly pure ice sent by a patient from northern Penmslrania. Withont going more into detail, this will give an idea of the infinite variety of presents received by him.

It always annoyed and displeased Dr. Agnew to be complimented for his work or praised for his skill; he had no craring for such retum, and he always tried to aroid it. At the time of the semi-centennial celebrations of his entrance into the medical profession, there were so many laudatory expressions poured forth on him by the medical profession, his patients, by the newspapers, and from the pulpit that he said it made him uneasy. He feared that the good people of Philadelphia wonld want to banish him, impelled by the same reason that the Athenians ostracized Aristides-because they had grown weary of hearing him called "the Just."

Doctors are only human, and they have instinctively their likes and dislikes among their patients; they live in a little world of their own, of which they are the centre, and in which they come into the most confictential relations with those who have intrusted to them their health. This relation is often eren more confidential than that which exists between pastor and prople.

The responsibility which a true phersic ian feels towatd his patients is something which bears heavily upon him. and yet, at the same time, brings him the lienest pleasure. I) de. Annew always regarded his duty to his patients as a most sacred trust, allowing nothing to intermpt its performance.

While D)r. Agnew did not allow himself to be biased by his personal feelings, still, like other physicians, he had his attractions and repulsions among his paticnts. To one among them, however, ever knew when he experienced the latter feeling; 
on the contrary, they rather regarded themselves as the farored ones. Fortunately they were few in number, for Dr. Agnew was as fond of the majority of his patients as they were of him. Once in a while, however, he would meet with a patient who tried his forbearance to the utmost. Every practising physician has some such patients, the very sight of whom tires him as soon as they enter his office-door.

These patients have usually been seriously afflicted with some ailment at one time, from which they have recorered, but they have been unable to rid their minds of the delusion that they are still snffering from disease. Dr. Agnew, by his prominent position and well-known forbearance, attracted to him from time to time a number of these hypochondriac cases. He knew too well beforchand the repetition of the long, unnecessary rerital of their peruliar woes.

1)uring his illness of a year ago, there was one patient who called on him regularly every day to see if he were well enough to attend to her wants. Her all-consuming concentration on her own sorrows had dimmed her anxiety for his condition, excepting the desire that she wanted him to get well enough to attend to her. She impressed upon those whom she met the great derotion which Dr. Agnew felt for her, and said: "If he linew I were down-stairs, sick as he is, he would get up and come down and see me." So persistent was she in her daily calls that when the doctor finally recovered sufficiently to see a few selected alses oreasionally, her name, without his knowledere. was put among the tirst on the list. As soon as his eye ranght this firct he exclaimed, "I would give a hundred dollars not to se that chatter-box. Write and tell her that I cannot sor lere." When he was expostulated with that she would linow that he was secing other patients. he said, "Well, tell lire I have gone to Europe to be gone indefinitely; or make any other excuse, I don't care what." The sequel proved, however, that. in his kindness of heart and forbearance, she had the privilege of seeing him among the first, after all. 
Dr. Agnew, like most publie men, was a target for all sorts of cranks seeking advancement or self-adrertiement. Just as his connection with the Garfield case brought him humdreds of letters, giving him all sorts of presumptuous advice, so in his own case in his final illness. His mail at this time was filled with all sorts of communications telling him how he should be treated.

How tender and beantiful was his love for his semi-invalid wife! Always extremely delicate, her life was sared many times by his matchless skill and unsleeping care. During one of the serious illnesses of Mrs. Agnew's life, such was lis derotion to her that for orer three months he nerer went to bed nor eanght more than a few momentary suatches of slecp. It was his terrible expenditure of medical skill and nursing which brought her back to life many times, after she had laid at death's door for many months. The derotion of these married lovers for a period of fifty-one years was such as to call forth the admiration of all who saw them together; and yet, with the curious irony of fate, she, who had depended upon him almost for existence itself, outlived all his splendid vitality.

In the bigness of his heart, Dr. Agnew found room also for the rest of his little family. IIow gently and kindly we were treated! How many pleasures he gave us!

A more uncomplaining, easily satisfice man than Dr. Agnew never lived; never depressed, but always cheerful, with a pleasant word and smile for every one, and a lindly courtesy which extended to the youngest member of his houschold and the humblest servant, small wonder it was that we should vie with each other in our attentions to him. Nothing but the best was good enough for him, and in return how we treasured his words and looks of thanks!

In all the years which I spent with him, although he was grieved and hurt many times, never once did an angry word escape his lips. IIow marvelonsly he forebore to risit us with his righteous indignation when we so richly deserved it! 
I will give two little instances of his forbearance: In the fall of 1880 I was intrusted with a large roll of manuscript of his work on surgery. 'This represented the work of years. I wals to bring it from his office, 1611 Chestmut Street, to Haverford. On the way out I made several stops, and by the time I reached IIaverford I became painfully aware that the manuscript was not with me. I went in fear and trembling and made known my loss. Sot a hasty word did he ntter. He simply fonleed at me. and said "That was the work of years." My feclings can be better imagined than described. A thousand scoldings wonld have been as nothing compared to that gentle reprool. He proved that he could bear the loss of the work of year. like sir Isala Newton, with equanimity. Telegrams were sent in all directions; the dépot and the car in which I rode to Haverforel were thoroughly searched, but the manuscript could not be fomd. 'The next day, half dead with grief and anxiety, I went to the eity determined to get that manneript. At the first place to which I went I fomed the roll. junt where I had, with childi-h heedlessness, put it the day before.

In the summer of 1881. during President Garfield's illness, 1):. Lenew was waylaid by reporters fiom papers all over the combly. Onr lomse and grounds were in a state of sicge, while a wroup of reporters always chustered about the station at the lours at which Dr. Annew was expected to come from the city. At the ond of a month we were mildly indignant; at the encl of six weeks we were desperate. One night a dapper little reporter ame to acet a correct aceount of the President's condition. Ife left his hat and stick in a dark corner of the porch. Knowing 1)r. Innew's thorough dislike of interviews, as a rhiblish revenge we collected a fiew pins and placed them in the lait of the . linight of the pencil," where they would be most reftertive. We then retired belind a bow-window and awaited renlts. We had not long to wait, for Dr. Agnew was brief in his interviews. The reporter bowed himself ont and then placed his hat firmly on his head; but he quickly took it off 
and said something energetically under his breath. The next day we had forgotten all about it, but the unfortunate reporter evidently had not, for hall a column of the first page of his paper, commencing in great head-lines, expressed in a humorous style his appreciation of the trick. On account of the tremendous publicity given to it, I felt, in my childish mind. that I had disgraced not only myself, but my dear uncle, and I trembled to meet him; but when I finally mustered up courage to see him he laughed, and referred to it subsequently as a good jolic.

Dr. Agnew was often urged to write an autobiograpliy; he was frequently told by relatives and friends that the story of his life, as told by himself, with his own description of his struggles, ambitions and successes, would be wonderfully iuteresting and absorbing, as well as the greatest encomagement to younger men in the profession. Dr. Agnew, however, could never be induced to undertake this task, mudervaluing the probable interest of the world in the details of his life.

He grew fonder of poetry as he grew older. and nothing pleased him more than to listen to the reading or recitation of some poctical selection. He was also rery fond of hymms, especially those of Charles Wesley. Alter his death, the following rerse was found betwen the leaves of his furorite Bible, and was, probably, one of the last things he had copied and kept. This hymu must have seemed to him, in his waliened state, most applicable to himself; it certainly roiced his feclings, - the first natural fear of death overeome by the thought of an eternity made beantiful and blessed by the Master he had so long and faithfuliy served. This hymn had been written by the good and pious Wesley as he was dying:-

"In age and foeblenesi extreme

Who shall a helpless worm redeem?

Jesus, my only hope thon art,

Strength to my failing llesh and heart;

Oh! could I atch a smile from thee,

'Then drop into eternity." 
Dr. Agnew was the humblest, the most consistent Christian I have ever known. Of all his kindness, generosity, goodness, and purity the world will never fully know. His earnest life, unswerving piety, and truly Christ-like efforts to help the needy and afflicted brought their reward; for when the summons came, "Good and firthful servant, enter thou into the joy of thy Lord," the white head and gentle ficce of this grand old saint upon earth was suddenly beatified with a light of such clear shining that hearen and earth seemed rery near. Can we doubt, with this manifestation to our earthly eyes, that the heavenly welcome and crown were wanting? 


\section{CHAP'TER XII.}

\section{Dr. Agrew's Later Life.}

Dr. Agnew's later life did not differ in its details and methods from the work of the rears that preceded it. He had not changed as he grew older; he remained the same milk. unaggressive, hard-working surgeon IIe rarely showed his strength. There are many workers in different fickds who nise at all times all the power and influence which they possess. but Dr. Agnew was not one of these. IIis only exhibition of his influence was in his efforts to forward the position and standing of his friends and students.

He never refused to aid a former student, and many a physician to-day can recall some deed or letter of Dr. Agnew which has opened new fields or made patlis easicr for himsolf. This interest in his brother-workers was one reakon why br. Agnew became the idol of his professional brethren. A single instance of it is shown in the following incident, which repeated itself innumerably in his career. The circumstance is told by the physician to whom it occurred :-

"Twenty years ago, when a young man just pushing my way into practice in my native place, a rery sad case came into my hands from some very much older mens. Worriced very much indeed abont it, and sorely in the dark how to aroid a renewal of the failures that land met my predecessors in the case, I called one erening at I)r. Agnew's old home on Chestmut Street, and, although it was long after office hours, he received me, and listened attentively to my list of troubles.

"Then, begimning at the bottom of my ase, he unraveled the whole thread, showing me where the fitilures were long before they seemed failures, and sent me away not only master of my case, but kindly assured of his interest in my success, 
and with an appointment to see him again in a few weeks, that I might report to him the history of my success.

. With the remembrance of that circumstance in my mind, I have always felt that a large portion of the success which has come to me here was owing to the advice given me by 1)r. Agnew, which made me successful where others had failed, and brought a young M.D. into the prominence which gave him the opportunity of caming his position."

During these later years of his life Dr. Agnew became more active in socicty life, being elected president of a number of societies of which he had been a member; so that he became more prominent than he had been in his earlier years in this branch of work.

1)r. Lonew never was an office-secker, and never wished to be one; the minutix, the intrignes, the wire-pulling, and tact which are necesary for successful society work are just as well maked in medical politics as in other forms, but they never fiscrinated him. Ile was too busily engaged in the practice of his profesion to turn aside for the honors and emoluments of such work. Then any position was offered to him of trust or honor he accepted it gratefully, ans a manifestation of the wishes of his friends, but he was not a man who cared to organize societies or carry out their rontine.

It the same time he was honored by being elected to the furevicleney of erery medical organization of which he remained a member. The first medical society which he joined was one in which he had been instrumental in organizing.- The Iancaster ('ounty Medical society; while in the country he had joined with a number of fellow-practitioners in the formation of this influntial body of medical worliers. The following letter in this connection explains itself:-

LAXcaster, February 21, 1889.

My I) EAR TocTor: On the morning of the 14th day of February (St. Valontine), of the rear 1844 , twenty-three physicians, then residents of he eity and comty, assembled in an 11 p)er room, third floor, of Krampf"s builing, cormer of Xorth Queen and Orange Streets, in the eity of Lan. 
caster, for the purpose of organizing the Lancaster City and County Medical Society.

If memory carries you back to the time staterl, do you remember being present on that occasion and taling lat in the proceedngs? The record marks your presence.

The Society has just passed its forty-fifth ambiversary, and I am selected to write hriefly and congratmate you with my-elf that of these twenty-three physicians there are but two smvirors (Drs. Annew and Ehler.) If your general health is goon and physical activity alike crood, you are 11 to my standard. I perform the active duties of my pofession as of yore. I am free of pains and aches, sleep well, have a good appetite, eat all the good things that come my way, and do mot refuse a glass of "champy. "to wash the cobwels from the funces. If foul have a fondness for old things, I send list of original tuenty-three as they appear on the minutes of Society.

With kind regands, very truly your's,

J. Aug. EllLkR.

To D. HAYes AGNew, M.D., Phila

On his advent in Philadelphia. the first society to which Dr. Agunew was elected was thr Philadelphia Combty Merdiant Society, in 18.58. It will be seen that he liver in Philadelphia ten years before he became a momber of this ereat sorioty. 'l'his action on his part is a sufficient commentary of his position toward societies at the time. Ife was rewirded for lis long service in the society by his election as prexident of this influential borly in 1892.

In 1859, one year after his olection to the Combty Medical Society. he was made a member of the college of l'hy yedians.the oldest and one of the most distinguished medical asorodiations in this country. Alter a mombership in this society for a period

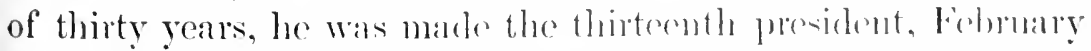

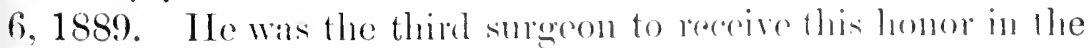
history of its existence, the first - wreon being William shippen, who was made president in 180 ). sucereding Joln lindman, who had been the first president for sivtecn rears, while the second had been 'Thomas Ilewsom. in 1s:35.

Dr. Agnew, while at the hoald of this angunt body, accord- 
ing to the traditions of the society, delivered three ammual addresse-December 4, 1859; 1)ecember 3, 1890; and Decenber 2, 1491, at which latter date he retired from the presidency. This last adelress was remalriable, an being the last one which he delivered in any official cayacity. He was elected a member of the Medical society of the State of Pennsylyania in 1870 , and he was invited at the twenty-serenth annual session of the society, held in Philadelphia in May and June, 1876, to deliver ".The Address on Surgery." IIe made this report of the progress in surgery tor the rear one of his clear, claracteristic papers. At the twenty-ninth session of the society, held in Pittsburgh. in Mar, 1875, Dr. Agnew delivered the President's adhess, taking as his subject, " Errors of Diagnosis." He had been elected President of the Society the year before, at the meeting held in Harrisburg, June 14, 18т\%.

He was elected a Fellow of the American Surgical Association in 188:; this society had been recently founded, in 1880, by the late P'rofessor Samuel D). Gross. I)r. Agnew was elected President of this association May 14, 188\%. II is impromptu remarks on being elected President were considered so excellent by the members of the society, at the time, that they were inserted in the preface to the volume of that year's 'Transactions. He spolie extemporancously as follows:-

"I confess that this amomucement is to me one of regret as well as of smprise and pleasme; rearet becaluse when I look over this distimgnisher borly of men-of lepresentative men-I see many who would discharene lle thities of this oflice with more dignity and more efliciency

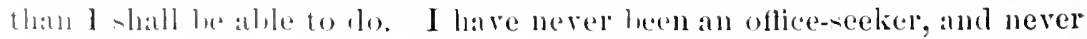
wish to be one. I experience also a feeling of pleasme, becamse it is no -mall homor to presille orer a borly of distinguished men like yomrselves. I recept the onfere not so much for the honor it eonfers. but hecause it (nmes to me mosolicited, and conveys to me the good wishes and good feching of a body of men whom l love."

(On September 20, 1888, he delivered his address as President of this association, taking as his subject "The Relation 
of Social Life to Surgical Disease." 1 It the meeting of the socicty, held September 20, 1ऽ91, at Washington, I). ('.. he delivered the opening address, taking as his subject "The Present Status of Brain Surgery." Although this was the last paper that he prepared, he displayed in it cren more than his usual care and brilliancy in dedncing conchusions from the data of which he treated. One of the most distinguinhed surecons present at the meeting said, on hearing this paper read: " These are revolutionary times, and it is to me al great satisfaction to hear the present Nestor of American surgery take such an alranced position in favor of operation in every case of depressed fracture, with symptoms or without symptoms."

At the Congress of American Phrsicians and Surgeons, held at Washington, I). C., in September, 1888, Dr. Annew, as President of the American Surgical Association.. was First VicePresident, ex-officio, of the Congress. On the fourth day of its meeting, Thursday, September 20th, at the convention of the delegates in the hall of the National Musemm, to listen to the address of the President on "Medical Museums," I)r. Agnew presided.

'To render social intercourse among medieal men more frequent and at the sime time to diffine among them professional knowledge of the day, eertain well-known physicians formed chubs, which met one erening every werk at the residence of each member in rotation. The entertaining member invited other physicians not belonging to the (dub), to the mumber of twenty or more. The referetion giren was limited to teat, coffee, bread and butter, and whes. and the conversation was usually on professional suljerets.

The Mondar-Fuening ('lub was probably the okdest among these. It inchuded such men as Drs. Franklin Parche, Ilonry

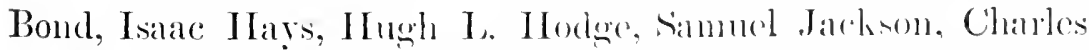
D. Meigs, George B. Wood. and Fanneis 1). Condic. Next in seniority was the Friday-Eveninge ('lub, among whose members 
were Drs. Robert Bridges, Joseph ('arson, George Fox, IV. WV. Gerhard, (aspar Morris, and Geo. W. Norris. The "Social Medical," or 'Thursday-Erening C'lub, was a still later organization. Its members were Drs. D. Hayes Agnew, John B. Brinton, Edward Hartshorne, Samuel Lewis, J. H. B. McClellan, J. Forsyth Meigs, John Neill, Edward A. Page, William Burd Page, William Pepper, R. A. F. Penrose, B. Howard Rand, Lewis Rodman, Robert E. Rogers, W. S. W. Ruschenberger, Francis G. Smith, Alfred Stillé, and Ellorsley Wallace,-in all ninetecn, of whom five are living. 'This list constituted the club for $1873-7 t$.

The Social Surgical Club was started in 187\%, as a medium for different surgeons of the city to meet occasionally for mutual improrement scientifically and acquaintanceship socially. The first meeting of the club was held in the office of Dr. John H. Parkiud, to whose exertions the existence of the club was chictly due. It was the original intention of the incorporators of the club to invite one or two surgeons from each hospital in the city to join, each member bringing cases for mutual study, reading pepers, and carying on discussions on medical subjects. 'The refieshments were to be limited to something very mild, such as beer and pretzols. Under these conditions the society continued to meet for some time. Its original nembers were 1) $\therefore$. Agnew, Brinton, s. W. Ciross, Hunt, levis, Morton, Manry, Roed, Packind, and Mears, - the membership being limited to ten. In 1879, on the death of Dr. Maury, Dr. S. 1). (iross wats clected to the vacaut place. After the admission of this last distinguished sureon. no new members have been admitterl to the "Surwical Club," as it is fomiliarly called.

liy this time the rocial sille of the society had become so pronomed that the medical features sank into insignificance. 'The cont of the dinner errathally increased, and the ménu became colmesondingly more elaborate; still, in the matter of bererateres only beer and sherry were allowed. Tradition reports that only once was this rule broken and champagne indulged in. 
At the suggestion of the elder Gross, soon after his admission to membership, the scientific and social featnres, which had long been estranged, were totally divoreed in 1879. The society continued to meet and retain the social features. inviting distinguished visitors who chanced to be in the eity to its dinners. There are now but three living members of the club, Drs. Brinton and Packard laving resigned, Drs. Agnew, Levis, Vaury, Reed, and the two Grosses being dead.

The Academy of Surgery was started to revive the lagging medical features of this surgical chub. The Acadcmy was founded April 21, 1879, and incorporated December 2 $7,1879$. Dr. Agnew was one of the founders, and in January, 1880, was elected the first Vice-President. Its first President was the gentleman who was responsible for its existence, D1. S. I). Gross. In October, 1884, Dr. Agnew was eleeted to the presideney; this post he retained until Jannary, 1891, when he resigned, being succeeded by Dr. William IImt.

Dr. Agnew delivered the ammual oration before the Acalemy in 1882, his subject being "The life and Writings of Jiaron Larrey." He was always active in its work, and the minutebook contains many references to his contributions to the proceedings of the Academy.

Among the societies of which Dr. Agnew was a nember, none gave him more sincere pleasure than the little undergraduate society named in his honor. It was not merely the fact that it was named in his honor that made it dear to him, but more becanse he was peculiarly fond of medical students and solicitous for their welfire. Ifis relations with his students were always like that of a liatlere to his sons. Ile hald the happy faculty of impresing upon his scholars the finct that he took a personal interest in each one. This interest was genuine and maffected. IIe always did everything in his power to further the adrancement of those who had studied under him.

This Agnew Surgical Society was founded in the winter 
of 1857-8S, by a coterie of students who intended to derote as much time as possible to the study of surgical matters. In order to accomplish this, it was the intention of the society to invite authorities in different branches of medical work to lecture before them, in addition to the preparation of papers by individual members. This lind of work had been done before by other medical societies, to a certain extent; but it was carried out more fully and more comprehensively by the Agnew Society. Of course, the founding of snch a society, with three well-rown. active societies in opposition, was at first somewhat of a difficult matter; but the name of $\mathbf{A g n e w}$ is one to conjure with. and in less than three months the new society took a foremost position in undergraduate life.

It stirtal with a course of brilliant lectures by leading anthorities; it did much original work, but particularly in its banquets was it happy. It accomplished in its first year what hald never been done before by medical undergraduate societies, -that in. gathering together neary the entire Faculty at its first anmal banquet. These banquets undoubtedly were a great feature in the life of the undergrachate who was fortunate enough to be a member. 'Tle opportunity to come in close contart with the Faculty,-especially with Dr. Agnew, - the stimulus. the inspiration, and the pathos of the occasion, made it $: 11 \cdot h$ an event that it was not very quickly forgotten by its partiripants. Dr. Aenew was president ex-officio of this society.

On Febraty 21, 1891, at the annual banquet for that year. 1)r. Agnew presented to this society a "loving cup," from which earh year each nember was to pledge lis renewal of corol fellowship. On one side is the Annew coat of arms, on the othere the motto "Sapientia com latitia."

Ilawthorme has silid. somewhere, that there are chasms betwen mon which an never be thoroughly bridged over; that there an mever be that thorough interplay of feelings. thonghts, and emotions as exists between man and woman or among women. The nearest approach to the remoral of this isolation 


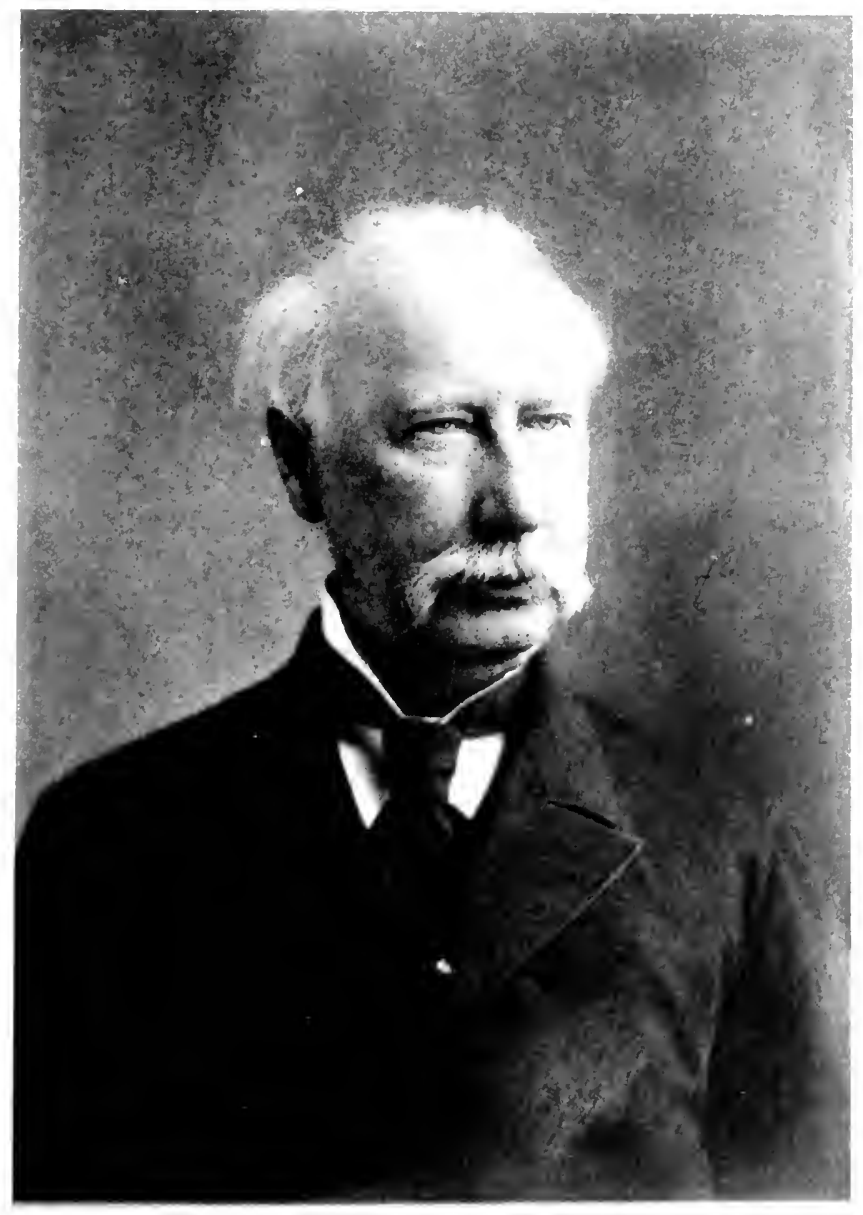

Dr. AgNew IN 1 SSL 
existed, undoubtedly, in this little Agnew Surgical Society, between Dr. Agnew and his students.

Another society of which Dr. Agnew was a member, but which was not medical in its nature, was the Wistar Association, which gave the famous "Wistar Parties." 'This Assoriation, which had ceased to exist in 1863-6t on account of the political excitement which was dereloped at its meetings. was re-established in 1886 by Dr. Canper Wister, one of 1)r. Anuew's most intimate friends. This organization was called. later. ". The Saturday-Night Club." 'These moctings were hold on Silturday evening, beginning at 9 o'clock, and each member was entitled to invite a certain number of outside guests to them. 'They formed gatherings remarkable for their social and intellectual attractions.

Dr. Casper Wistar. the former Professor of Anatomy at the University of Pemsrlvania, was the originator of the " Wistal" Parties." He was in the habit of receiving his friends and scientific strangers at his house on Sundar eveningr. and npon his death, in 1818, a social circle was formed amone the mombers of the Philosophical Society, to which was given the name of " Wistar Parties." The meetings were held sub-clucutly on Saturday evenings, continuing mil 1863-64.

Dr. Agnew was also a momber of the medical finternity A M II $\Omega$, being elected in 1891

Dr. Agnew righthully beliered that. to snceed in modicine, every energy and every thought mun be concentuated ly a physician on his life-work. henere he diel not acels omt side work or positions; yet he held a fow positions of honot and trust. not of a medical character, which came to him at different times. He was appointed a Manager of the Homse of Rofinge ly the Judges of the Courts of Common P'leats of Philadelphial in 15,5e. He was at the time of his death he hin the oldent member of the Board, so much so that none of the present mombers have personal knowledge of the condition of attairs when he was appointed. They all have a trarlition, howerer, that he worked 
great changes in the sanitary department, which subject was very little understood by the public at that time. As an example of this reformation, at the time he became manager it was customary to have the towels used in common by the inmates, and, in consequence, a large part of the time, many of the children suffered with sore eyes. At Dr. Agnew's suggestion this was altered, so that each inmate was given his or her own personal towel. So much information is given in the resolution adopted by the Board of Managers, of his relation to this insti. tution, in reference to Dr. Agnew, after his death, that it is quoted in full :-

"Dr. Agnew has been a member of this Board of Managers for the past thirty-three years, always manifesting a deep interest in the administration of the institution and the relfare of the ebildren. Ready at all times to advise upon the sanitary and hygienio problems frequently arising in the administration of so large an undertalking, his counsel has been invariably songht and eheerfully given.

"His interest in the work and appreciation of its usefulness grew with his years, and it was not until after a personal inspeetion of the site selected for the new Institution at Glen Mills that the eontract for the purchise was entered into. His approval of the system to be employed there was unqualified.

"In reeording his generons and philanthropie spirit and the deep sympathy erineed hy him with the mfortmmate children committed to our care, we are but nniting in the universal testimony to those qualities which he exhibited throughont a long and distinguished professional eareer, levoted to good deeds and generous acts."

Mr. Collins, who died November 27, 1892, the venerable President of the Board of Managers of the House of Refuge, had been in the board twenty years; this made him quite a youth compared with Dr. Agnew's service of thirty-three years.

1)r. Agnew was a member of the Board of Directors of the Union 'Trust Company, one of the largest financial concerns of Philadelphia. 'This company was a conception of Colonel William C. Patterson. of Philadelphia, its charter being obtained on the 16th of October, 188:. Dr. Agnew was made a mem. 
ber of the Board at the first meeting of the Company, and continued in active service up to the time of his death. He was always in attendance at the meetings of the Board, unless prevented by his professional duties, and his adrice and counsel were always sought and esteemed to be of great value. $\mathrm{He}$ did not waste much of the time of the Board in long discussions, but he did not hesitate to express his views very freely, when the occasion required it.

At a meeting of the Trustees of the Philadelphia Dental College, held November 29, 1881, Dr. Agnew was unanimously elected a member of the Board. On April 19, 1872, he was made a member of the American Philosophical Society for Promoting Useful Knowledge. He was also a member of the Franklin Institute.

On February 19, 1872, Dr. Agnew had been elected one of the Consulting Surgeons to the Presbyterian Hospital; in 1890 , he was made Honorary Surgeon to the same institution, the first time such a position had been created.

At the meeting of the Alumni Society of the Medical Department of the University of Pennsylvania, held May 6, 1891, he was elected Vice-President of the society. This was an unusual honor, as the officers in this society, as a rule, are not chosen from among the members of the Faculty.

Dr. Charles T. Hunter, who lad been Dr. Agnew's Demonstrator of Surgery for many years, resigned from this position in 1882; he was advanced to the position of Demonstrator of Anatomy. His place was taken by $\mathrm{D}_{1}$.J. W. White, who assisted Dr. Agnew in much of his work until the latter's retirement permanently from professional duties.

Dr. Agnew delivered the introductory address to the course of the winter 1881-82, and the valedictory address to the graduating class in 1885 .

At the time of the consideration of the necessity for the establishment of a compulsory fourth year, in 188\%, Dr. Agnew was one of its most eager advocates. 'The successful establish- 
ment of this medical adrance at the University met with his warmest approval.

1)r. Annow continued his lectures at the University until the spring of 1889 . During the winter he intimated his desire to retire from active service, which was accomplished by his election to the post of Emeritus Professor of Surgery and Honorary Professor of Clinical Surgery, Jannary 11, 1889. By the former position he was still a member of the Faculty with all its privileges; by the latter title-one never giren before in the history of the University-he was cnabled to deliver cliniques to the students whenever he so desired. This intention he carried out from time to time until within a short period before his death.

'The incidents and anecdotes which throw side-lights on a man's character and career are often fortunate in revealing the colors and details of a human life which would otherwise be lost forever. There are many such ancelotes that remain of Dr. Annew's career which tell, far more forcibly than mere description, of many of his characteristics; some of them demand a place in the story of his life. for their value in thus disclosing glimpses of himself or of the environments of his life-work.

II is regular attendance at church was so marked, especially in such a busy physician, that the following little incident, which shows his arrangement of his work in order that he could get to church, will not only serve as a lesson for practising physirians, but also emphasize the sacrifices to which he put himself. in order to be present at divine worship:-

ln the early seventies he aslied a young surgeon of the city to accompany lim to Giloucester, New Jersey, to see an interchting casc of abdominal tumor in a woman. It was necessary to see the case the next day. which happened to be Sunday. The young surgeon suggested 10 o'clock as a good hour for starting; his surprise can be imagined when Dr. Agnew told him he would stop for him with his carriage at half-past four in the morning. Dr. Agnew arrived on time, and they reached the 
ferry by 5 o'clock, took the first boat orer, and Dr. Agnew was back in his office by 9 o'clock.

Dr. Agnew's quickness of retort and his ability to sce the humorous side of things are shown in the following incident: A gentleman in the country was mortunate enough to swallow a set of false teetlo while eating oysters; they stuck in his throat, from which position they could not be dislodged by the efforts of the country physicians who were called to attend him. In consequence, the gentleman came in great distress to town to see Dr. Agnew. After a little manipulation the doctor remored the teeth from the throat of the unfortmmate gentleman, and left him in a condition practically as good as before the accident.

The news of this incident spread through the city, and consequently a reporter called on J). Agnew about midnight of the day of the extraction. As was Mrs. Agnew's rustom, in order to sare her husband as much exertion and exposure as possible, she answered the call to the night-bell. She told her husband that there was a person down stairs who wanted to know about the man who had swallowed his teeth, and had been operated upon that day. Dr. Agnew liughed and said: "Tell him that if he doesn't go awa from my door there will be another man in Philadelphia to-night with his tecth down his throat."

In the Medical Neres of July 28. 1883, under the head of "Correspondence," are a couple of letters on a publication, entitled "An Epitome of Medicine. Surwery, and Obstetrics, by Alfred Stillé. D. Hayes Agnew, and R. 1. F. Penrose. Published by Samuel M. Miller, M.D." The following explains itself:-

\section{To the Editor of the Medical News.}

Sir : I am receiving letters from various sections of the country asking for information in regard to my eonnection witl a little volume published by a Dr. Samnel Miller, aul entitled "An Epitome of Medicine, Surgery, and Obstetrics, ly Dis. Altred stillí. D. IIsyes Agnew, and R. A. F. Penrose." I have no desire to increase my "orrespondence, alrealy too onerons, and, therefore. deem it best to avail myself of the 
columns of your widely-circulated jonrnal to inform $\mathrm{my}$ professional herthen that I lisown any relation whatever with this miserable piece of literary larceny, published entirely withont my knowledge, and only remarkable for inaccuacy, stupidity, and andacity on the part of its author.

Yours, truly,

July 21, 1s83.

D. HAYes Agnew.

An injunction was granted subsequently against Dr. Miller, restraining him from publishing and selling this medical work. On brhalf of the defendant, it was argued by his attorney, E. Spencer Miller, that an oral delivery of matter to persons, who attended such lectures on invitation or otherwise, became common property to those who were present and remembered the subject discused. He said that the students had nerer been notified that the lecturers reserved the right of property in their lectures, brit, on the contrary, directed their students to take copious notes of the lectures. Judges Hare, Mitchell, and Fell refused to dissolve the injunction, saying there was not sufficient evidence shown to induce the court to dissolre it. Still later. in the case of appeal of 1)r. Samuel M. Miller from the decree of Court of Common Pleas, No. :2, the Supreme ('ourt confirmed the decree of the lower court; so that the book was permanently suppresed.

The following incident occured many times in Dr. Agnew's career when he was called into consultation. He would meet the attending phrsician at the house of the patient, examine the case. and retire to an adjacent room in which to talk over the car. As 1)r. Agnew was discussing the problems presented, lie would be at the same time glancing around the room. On crory side he could see cridenees of a long, unsuccessful struggle against porerty. The threadbare arpet; the dingy fumiture; the pinched. wan face of the wife or mother,all told their story of a bitter struggele. When the time came for lim to go. as was customary in these cases, the attending physician would ask 1)r. Agnew his charge. Dr. Agnew would mention the amount of his bill, the physician would confer with 
the mother of the family, and Dr. Innew woukd be paid at once. On the way to the door, Dr. Agnew would find some pretext to see the woman unobserved and slip back into her hand the money which he had just received. In a second he was gone and no one was the wiser of the act, not eren his family or the attending physician.

It has been wisely said that a fool cannot lose his temper, and a wise man does not. Dr. Agnew's control of temper was not due to any inability to see harm done him, or provocation aroused. He could, on occasion, be most stern and decisive in his words and actions. They seemed all the sharper and sterner because they were so far apart. He liad a considerable amount of the old Scottish blood in him. An incident will illustrate this: In his earlier years Dr. Agnew attended a woman suffering from an incurable affection,-chronic tubercular peritonitis. Eventually, despite all that was done for her, she died. In the course of time Dr. Agnew presented his bill to her husband. He knew that the man had been put to considerable expense and was not in the best of positions financially. His bill, even at the moderate charge which he was accustomed to make, came to $\$ 180$, but he divided it by ten and sent a bill for \$18. A year rolled by, and as the bill was still unpaid Dr. Agnew sent his collector, who was subjected to a considerable abuse. Somewhat later this man sent the bill, with a check, to Dr. Agnew, with the following letter:-

Dr. AGNew.

Dear Sir : I enclose your bill with rheck therefor. Kindly receipt it and retum to me. I will saly that I never paticl a bill under greater protest. You promised to cure my wife and you failed to do it. I feel that you are an ineflieient pluysician and incapathe of giving proper medical attention to your patients.

Yours, ete.,

Dr. Agnew sat down, receipted the bill and folded up the eheck, and put them together in an envelope, with the following note:- 
DE.xk sin: I enclose yon the receipted bill, also the eheek which yon sent. Permit me' to say that I never promised to cure your wife. Thal is a power which belongs only to God, and if He does not bless our eflorts our medicines are of no a vail. I will only ask one favor of you. It is that you will never darken my ofliee-door again.

Yours sincerely,

D. Hayes Aanew.

Such discourtesy was most umusual in Dr. Agnew's experience. The receipt of such letters as the following was, on the other hand, a common experience:-

My Dear Doctor: Twenty-three years ago, on the 14th of Mareh, I went ont to $\mathrm{O}-$ in the morning full of health and vigor, and returned in the afternoon a sald cripple, my right ankle-bones broken in pieces, having receired a compound comminnted fracture-the most terrible accident of my life. 'Then it was that, by your skillful and careful treatment and watehful attention, assisted by Dr. Smith, that you placed me mpon my two feet again, and, insteal of ever thereafter limping almo, I have triveled life's journey for twenty-three years longer, soum in both limbs. And as to-day is the anniversary of the accident, I wished to write you a few lines and tell you I hear in my heart the grateful remembrance of all your lindness to me. The poet salys: "A thing of beaty is a joy forever." To me, a kind act is a most mecions memory, and throws a brightuess orer all my after life. Aur can I forget your friendhlip, with all the kindness I have received from rou? Lerer. Years may and do bring many changes, but the heart that is true remains the same.

So, believe me as ever, affectionately yours,

Dr. Lgnew's study of human nature was often most marked, so that frequently he would let drop a remark which would linger for years in the minds of his auditors. For example: a gentlemam, in explaining to him the condition of a pationt, said. "Dortor. my fither is in the habit of taking a remple of omeses of raw whisky before dinner. Do you think he onght to give it up) Do you think it has a bad effect "upon his disonse?" Dr. Agnew replied: "No; a man of seventy should never break up eren a bad habit." 
A gentleman calling on the elder Giross one morning noticed lying on his desk a copy of "Agnew's Surgery," which was then just published. He asked Dr. Gross what he thought of the work. In the impressive style for which Dr. Gross was noted, he said, "I want you to listen to what I am going to say. I sat up nearly the whole of night before last reading this work, and I will venture to assert that 'Agnew's Surgery' will be read and consulted by the medical world long after the dust hats settled forever on the covers of similar works." The risitor atked, "How do you think it compares with your own work?" Dr. Gross modestly replied, "Why, sir, mine is, in comparison, a pigmy."

The following interesting letter, written to Dr. Agnew by Dr. Gross in regard to his "Surgery," shows the friendly relations existing between these two great surgeons:-

I'IIIIA DELI'IIIA.

My Dear Doctor Aanew: I thanked you in adrance list weele for your kindness in sending the second volume of your "Smerery." Now that an opportmuity has been aflorted me of scamning its ample pages, let me thanl you again,_not in a cold and formal mamer according to the world's fashion,-but with all my heart and sonl. Yon have produced a great and noble work, -one creditable alike to yourself, your profesion, and your country.

I hope and pray that the great and good Gorl-the Father of us all-may give you health and strength aud a long life to enjoy the wellmerited fruits of your labors. Ever fathfully your fiend,

S. I. Gross.

Dr. Agnew did not kecp many of his letters or otleer data in reference to his work. IIe was in the habit of destroying everything as soon as he had digested its contents; and althongh he left considerable material, it was not onc-lundredth of the amount which he destroyed. This is unfortmate for posterity, for it limits considerably the outlines of his life.

A Southerner who had (ome to Dr. A griew for advice. after leaving his office, went into a neighboring drug-store to have a prescription filled, asking if "this Agnew orer the way was the 
celebrated Agnew." Being assured that it was, he seemed to hesitate, and then said, "I came from far south and brought a thousand dollars in my pocket to have Agnew give an opinion upon a makady of mine, but I got that opinion and he only charged me three dollars, and I don't understand it." The druggist asked if he was slighted in any way; he replied, -. Slighted! No; on the contrary, he could not have treated me better; but why he did not charge me more I don't know. Ie merely said that that was his regular charge for office advice." This discegard of Dr. Agnew for possible advantages that he might take of those who came to him and his excecding fainess toward all people were strongly marked through his whole career.

Dr. Agnew said one morning to a friend, "I saw in my office this moning forty patients. How much money do you suppose I charged and received for my molning's work?" The firiend being unable to estimate, Dr. Agnew said, "Twenty dollars." In other words, he charged only one out of four or six patients. If he had only collected what even his moderate charges were, his estate wonld have been at least three times larger than it was at his keath. 'This hald an mexpected effect on the other physicians in the town. If Agnew charged so little it was difficult for other les well known practitioners to charge more. Fudoubtedly. I)r. Agnew's scale of fees had a bearish tendency in the wreat medical market. 'This cireumstance did not always, howerer. deter other physicians from charging their usual prices. (Men when called into consultation at the same time that 1)r. Agnew would also be called. For example, for seeing a pationt outside the city, Dr. Agnew presented a bill for $\$ 50$, while another professional gentleman, who accompanied him al-1) to see the case, younger and less well known, sent a bill

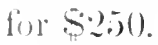

There were a number of incidents which occurred in Dr. Lnew: work at this period which are of sufficient importance to demand attention. One of these was the occurrence of a death; the only one which happened to Dr. Agnew in the whole 
course of his professional carecr, in which the patient died while under the influence of ether. As the case is of ereat value as a lesson in etherization, its outlines are briefly presented. Althongh the death was proved to be mavoidable, it is most lortumate for the medical protession, not only from the rareness of the incident, that it occurred at all, but that it fell to the lot of Dr. Agnew, and not to some less well known operator.

After forty years of surgical work, often of the gravest character, and sometimes requiring prolonged anesthesia, without a single accident, Dr. Agnew liad come to believe that the exhibition of ether, unless recklessly administered. was entirely free fiom danger. He was aware that several deaths had been reported from time to time from its use, even in the hands of the most careful operators, but he conld never divest his mind of the idca that in these cases there was some undertected element inrolred more influential in the issue.

Dr. Agnew was engaged in preparing to operate on a gentleman, tj years of age, for the removal of two nlerrating hemorrhoids. The paticnt was in good hoalth, the heart and kidneys not being diseased. One year before 1)r. Agnew had operated for fissure of the sphincter ani on this same patient, at which time he had done well nunder the ether. At the time of the second operation, nothing ocomed during the arty stage of the inhalation other than what is witnessed every day when ether is exhibited. In the course of fiftecn mimutes the patient was placed across the bed, one of the tmmors was drawn down, transfixed, and ligated with a donble ligature. When abont to seize the second, the breathing. which hat been strong and fiee, suddenly ceased. The operation was immodiately snspended, and the nsual methods for resuscitation instituted. Notwithstanding these measures were persisted in for at leant three quarters of an hour, during twenty-five minutes of which time the pulsations of the leart could be reeognized, not a single effort of natural respiration occured. 'lhe post-mortem, made by Dr. Formad, the coroner's physician, revaled complete col- 
linpse of the lungs; marked traces of an old meningitis, attributed to a former smo-stroke; and what satisfactorily explained the sudden termination of life, the rupture of a calcified ressel in the floor of the fourth rentricle, the recognized physiological centre of respiration. All the ressels comprising the circle of Willis were in a similar state of atheromatous degeneration.

It was crident, therefore, that the increased rascular tension of these ccrebral ressels, cansed by the ether, determined the lesion, - a result which might have followed any unusual mental or phrical excitement. Under the circumstances this sad disaster could not have been aroided by any human foresight. The ether was pure, not more than five ounces had been inhaled, and there had been a sufficient admixture of atmospheric air. Juring life it was impossible to ascertain the state of the blood-resicls of the brain as disclosed at the autopsy,-a very improbable condition in a man of 45 years.

1)r. Lgnew had, curiously, about the same time, a case in which he was called to see a woman more than 70 years of age, who was suffering from strangulated hernia. They were just preparing to give her the ether, when the patient gave a sudden convulsive movement and expired in a moment. Had the etherization been commenced or the operation begum before the death of the woman. the fatal result would have been attributed cither to the anesthetic or the linife.

The following tribute of respect to Dr. Agnew's memory was writen by a former patient. It expresses two such good points that it is quoted :-

- Ilis mamner in the sick-room is worthy of study; he wonld firt shake hands with his patient in the most kindly and courtly manner and it down as quictly and composedly as if he had mot another patient in the world, and evidently intended to remain until ererything had been discussed and considered. He woukl listrn patiently to the explanations of his patient, give his derisions and adrice quickly and incisively, and then refer to some topic of pleasant conversation which he knew 
would be of interest to the patient. When he went, he had made all feel that nothing had been left musaid or undone. Frepuently. after he was gone, my wife would say, $\cdot$ Olı, dear, the doctor never sees me when I am bad'; the fact being that she foret her suffering, and, after the questions as to her treatment had been decided, she had been endeavoring to entertain him hy showing him whaterer new shell, butterfly, or beetle she had rereived.

"Of Mrs. Agnew but little has been written. The world should know what a loving and kind-hearted woman she is, and what a help-meet she was to her husband. Is a matter of fict, he owes a large part of his success in life to her,-not, of course, his professional success, but it was by her great and unceasing watchfulness over him in sickness and in health, and relieving him from all business matters, from all petty anmoyances, that enabled him to derote his undivided attentions and ('nergies to his professional work. Never was there a couple better suited to each other."

Dr. Agnew's influence as an expert in medico-legal casces was a natural outgrowth of his work in other directions. His appearance on the witness-stand was always a somrec of impregnable strength for the side on which he testified. for his rast erudition and experience, combined with his well-known honesty and conscientionsmess, made it posible for him to relut any testimony contrary to his own which might be offered by an opposing attoner.

Dr. Agnew's testimony as an expert led him frepuently to testify in cases in which he felt that he should place on record his experience, especially when such expert testimony was wiren that he believed was domg an injuntice in any way to an inmocent person. For example, he went to New England in the spring of 1886 to testify in a case of a peor colored mant who had been charged with murder, in which the case turned upen the point, whether it is possible for an indivilual with suicidal intent to inflict a shot wound in the brain and another in the heart. 
Dr. Agnew was so honest that he frequently failed to see the intrigues of others; in consequence, he allowed himself occasionally to be the source of adrertisement to those who were seeking to adrance their own interests. This tendency on his part increased as he grew older; in his later years he permitted many things to pass which, occurring carlier in his life, he would have quickly stopped. This tendency was recognized by his friends, and it did not create the surprise which might have otherwise naturally arisen.

All through this decade Dr. Agnew was endeavoring to decrease his work; he resigned, in 188t, from the Pennsylvania Hospital, and in his practice he limited his work as far as possible. Still, he did far more work than he had outlined for himself.

When Dr. and Mrs. Agnew came to Philadelphia, they joined the church of the Rer. T. II. Beveridge, at Twentysecond and Race Streets. This was an Associate Presbyterian Church, of the same division of Presbyterianism of which Dr. Agnew's parents had long been members. Subsequently, they transferred their membership to the Tenth Presbyterian Church, at Twelfth and Walnut Strects, at that time under the charge of the Rer. IIenry Boardman, D.1). They remained regular attendants at this church until 1865, when they joined the Second Presbyterian Church, where, until his death, Dr. Agnew was a regular attendant.

In 18633 1)r. Ignew began his romantic attachment with the late Rer. Elias R. Bealle, D.D., when he had the pleasure, first. of hearing this gifted minister preach. It was in the Tenth Presbyterian Church where this occurred. Dr. Beadle took charere, temporarily, of the congregation of Dr. Boardman and of 1)r. Crowell dnring the absence of these pastors in the summer-time. Ife entered the church and took a back-seat on a side-aisle, until the hour for service arrived; then he arose, walked with a rapid. nervous step down the aisle, and ascended the pulpit. 'There was something about the man which im- 
mediately awakened Dr. Agnew's interest. The sharply cut features, the deep lines which furrowed a thoughtful face, and the quick, nervous movements, all revealed the fire which flamed beneath the surface. The voice and mamner, the form and force of expression, the elegance of diction, all conspired to make one magnificent harmony. Dr. Agnew, as well as others. at once recognized that in the delicate, wiry body of the speaker God had enshrined a soul full of beatitudes.

Notwithstanding the heat of midsummer and the depopulated state of the city, Dr. Beadle soon attracted large congregations of highly educated and appreciative hearers. The following year Dr. Beadle spent in Rochester, N. Y., supplying a vacant pulpit in that city; but the rigor of the climate compelled him to seek a more congenial spot, and, in 1865 , he was called to the Second Presbyterian Church of Philadelphia, then situated on Seventh Street, between Market and Arch.

In consequence of the drift of population westward and the encroachment of trade, a process of disintegration lad been going on for years in this historic old church which rendered a change imperative. When a few remaining worshipers turned their backs on the church hallowed by so many sacred memories, it was with sad hearts; after leading a nomadic life for some time, this body at length selected the site at 'Twenty-first and Walnut Streets, and there erected, in 1876 , the present imposing edifice, where the last, and not the least, prosperous years of Dr. Beadle's singularly successful ministry were spent.

Dr. Beadle, after his license to preach in 1835 , had been, for several years, a miscionary to India and Srria ; but his health did not permit of his continuance in this work, and he hat returned to America in 1843. From this time he worked in home fields. His intimacy with I)r. Agnew was markerl firom the ontset of their acquaintance. It was partly through I)r. Agnew that he was called to Philadelphia ; sarecly a day passed during the following years that they did not sce cach other. I)r. Boidle was fond of calling on his friend at supper-time; he would run 
in unamnounced at this timc, and these two workers would spend an hour or so in congenial talk.

(On Sabbath morning, Jannary 5, 1879, Dr. Beadle preached with his usual camestness and power, and at the close of the service tonchingly announced the consummation of a longcherished hope, - that he had lived to see cancelled the onerous debt which had hung over the beatutiful temple in which he and his people hatd worshiped, at the same time saying, "My work is now done." The words were prophetic; it was his last Gospel message; his work was done.

One hour later Dr. Agnew was hastily summoned to his aicl. On cutering the room in which he was placed, Dr. Agnew found the poor sufferer scated on a sofa, but, alas! how changed. IIe had been seized with the agony of cardiac angina, and the face that an hour before had been beaming with exultant joy was now shrunken, the wrist pulscless, and, with the desperate chutch of the fingers, wals heard the half-suppressed moan of one in mortal trouble. Shortly after midnight the gentle spirit of Bealle was released from its mortal enrironment and passed from the Church Militant to the Church Triumplant.

In 1880 the Rev. John S. MacIntosh, D.D., of Belfast, Ireland. was called to the empty pastorate. Me had charmed and delighted Philadelphia by his brilliant and feeling sermons the year before, during the Council of the Presbyterian Alliance. 1). Viac Intosh aceepted the call, and was installed in 1881. 1)r. Milchutosh's own worels in the estimate of Dr. Agnew's carecr. and his fimenal sermon, express the relations that existed between 1)r. Ifnew and limself.

These suggestive notes and reminiscenees are furnished by 1)r. Innew's pastor, who. despite the fact that he preached two (romene on I)r. Agnew's life in quick succession, still had left the exalutiful thoughts tonching his dead friend:-

"It was my happy fortune to be thrown very closely with Dr. IIases Innew from the very first moment of my return to Philadelphial, and it is a matter of highest satisfaction to my- 
self that the succeeding years only tightened the bonds of intimacy, until we became the very closest and most confiding of friends. During the later years of I)r. Annew's life, it is, I think, the simple truth for me to say that no man was honored with his closest confidences as I myself was, and no man saw or heard so much of his imner life.

"But a great deal of that which was thus in the freedom of frankest friendship unveiled to my eye must, through the sacredness of affection and a solemn sense of duty to the dead. remain forever sealed up in my own memory and guarded in my own heart. To rest a welcome guest at a man's fireside; to sit at his table; to share his lome-life; to enter into his sick-chamber; to talk with him when laid upon his bed; to read his uncorered spirit-life and enjoy his trustful confidences, and then go ont and talk about him and tell what was nerer expected to be told, and set in cold print what was only opened by a loving heart to a loving eve,--what true man, with tender heart and high sense of honor, can erer bring himself to play such a part! Therefore, it is not for me to say much of this imner life, and open up to the public ere many of these holy conficlenees.

"But times come and calls are heard when speech about your absent friend is the purest loyalty of the loving heart, and there are seasons when bus men and women, strugghing to do the right and to grow better, have a just (daim upon those that knew the purer and truer sonls; linew them not simply for themselves, but for the help of their fellows and for the olory of that God who, by his grace and presence. made these hright spirits very much what they were. 'There are a few cloice souls whom their fellows need to know. and it brightens the work to see them in their home-life and know a little of the play of their great, honest hearts. There are strong and sympathetic brothers whose inner life is the secret of their onter strengeth. The man in his home and the man before (iod explain the man among men and the man at his work.

"The wish to know the hidden man is right. Ever and 
anon there walks among the crowd one whose face shines, thongh he himself wists it not, and his wondering fellows, looking with awe and admiration on him, want to know whence comes that sweet but awful light; and when they learn the screts of the brightness it betters and sweetens their own spirits.

- Since Ignew went away from us there are many feeling poorer by his rery loss, and they are asking those of us who knew him best, whence came and what formed that singular wealth of personality which made richer those who touched our departed firiend. by their very contact with him? Hard, indeed, it is to pack such a man and the secret of his life into a few sentences. Yot were it serious wrong to him if speech were unduly long or pratise grow fulsome. The calm, severe dignity of this modest and self-hiding man demands that words be few and well ordered.

"What manner of man was this, as he hived among his more intimate friends and mored in the sweet circle of his home? He was a man of moral symmetry. Ile was a man of purest kindliness; of most derout piety; of settled faith and strong convictions; of broad eatholicity and spiritual generosity.

"Ilis Monerl Symmety"y.--In the human form what is more winsome thin symmetry; fine balance of parts; harmony; true puportions and perfect anticulation? To see a youth of symmetrie form is indeed a joy forever, but there is a symmetry of sonl, there is a moral balance, an equipoise which is finer and swecter by far than the bodily; a symmetry of soul where great rualities meet and are harmonized. IJayes Agnew carried with him this great and singular beauty of spirit.

"lonked at from the moral point of riew, there were few thing lacking in his spiritual make-up, and there was nothing out of proportion. Ite was marked by chanest truth, by childlike simplicity, by sweet modesty. heroic firmness, steady earnestne. winsome gentleness, unchanging cheerfulness, peculiar conscientiouness, and holiest reverence. Every one who knew 


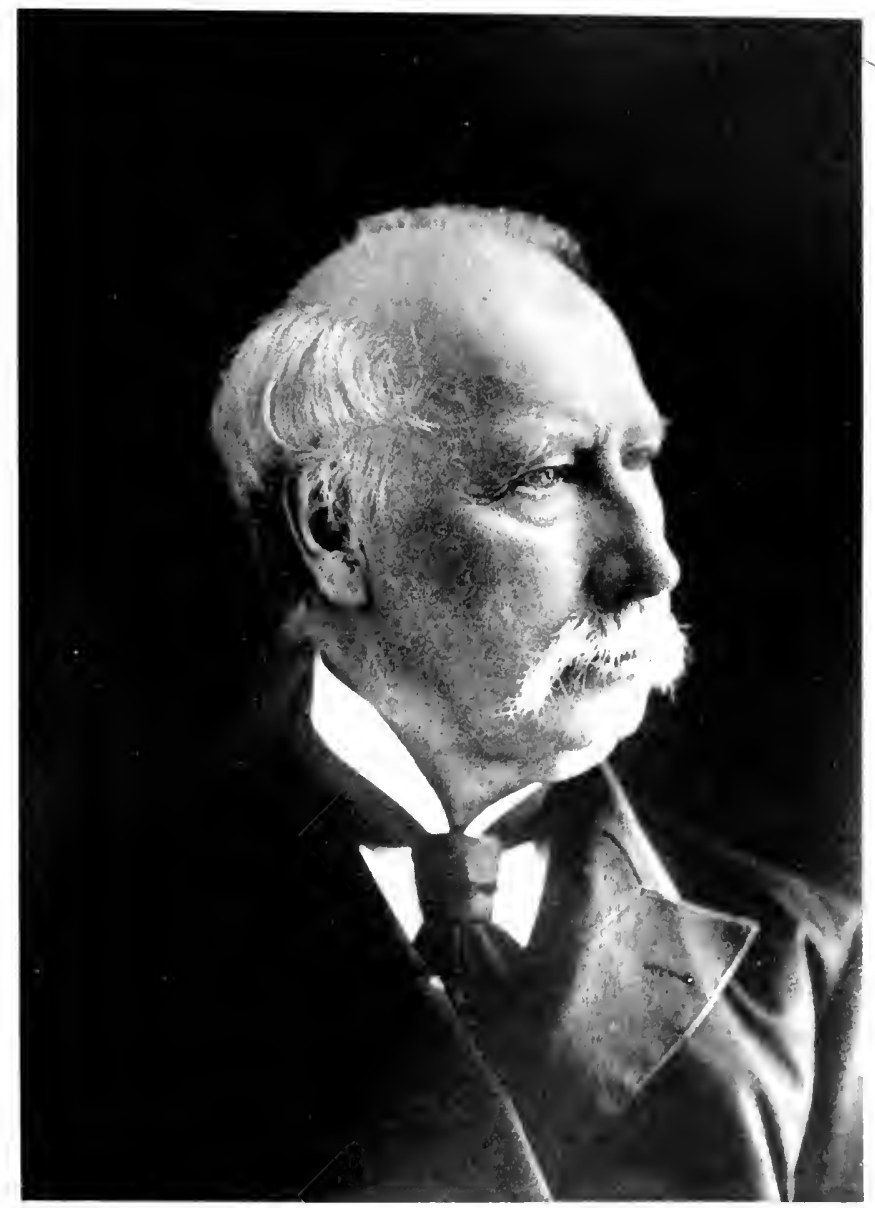

1) R. AgNew IN 1sis. 
him well would admit that each one of these high qualities of mind and heart and spirit was found in him, and that they all made themselves felt by those who came in contact with him, and that they shone forth brightly upon those who lived in the close relationships of near friendships and the home. And yet a singular fact was that you scarcely knew which of these was the master feature, for in him truth and gentleness, modesty and firmness, simplicity and earnestness, conscientionsness and forbearance, cheerfulness and reverence went together. One quality was checked by another; one feature balanced another, and they were combined into a sweet unity of a great, strong, good man. In the number, in the variety of his moral characteristies. lay much of the strength of his character, but the chice power of it was found in the happy balance of his features of soul. It was the strength of his character that tells largely the secret of his remarkable hold upon the community. Confidence in the man himself was, perhaps, as marked as confidence in the surgeon of unrivaled skill.

"His Purest Kindliness.-Agnew's eve was remarkable. Those who knew him well know and recall that fact. There was a steady penetration in it that seemed to go right down to the bottom of the person or the thing le looked at. But there was also in it a serene pity that made you feel you had found not a patron in him, but a fricnd It was a joy to him to do an act of kindness, and that was almost an hourly decel. 1)uring the later years of his life, when it bocame tolembly well known that he and I were very close, intimate firinds, I was eonstantly approached by those who were in need of help of varions kinds and desired an introdnction to D). Asnew. Wherever and whenever such an introduction was given, the applicant. whether in suffering or in want, was sure of a kindly hearing. and, with scarce an exception, receired holp and attention. 'There were three classes whom he recomized as haring what he called 'first claim on my care.' 'llhese were: doctors in suffering, sick and struggling ministers, and those of God's poor who 
were in special pain or burdened with incurable troubles. The most of his own profession hare testified in public to his open hand and open heart in meeting the calls of his suffering bethren, and the generosity with which he oftimes adninistered to the wants of those who, through physical infirmity or some inexplicable breali-down in their professional life, were no longer able to provide for themsches.

"It may be permitted me to say that if he was the doctors' doctor he was also the pastors' physician. Since his death there have multiplied to me singular testimonies of the pure kindliness and thoughtiulness of my departed friend to the members of my own profesion. Just last week it so chanced that public duty called me to a neighboring town, where, in a goodly company of Christian ministers, the conversation drifted to Dr. D. Ilayes Agnew. In the course of that talk this fact was pressed home upon my attention: that every clergyman there present knew sereral instances where Dr. Agnew had, for a longer or shorter time, ministered to some suffering preacher or given advice and lent his skill for the recovery of some nember of a ministerial houschold.

"One witness gave the following illustration: "A brother minister of mine went to Philadelphia to consult Dr. Agnew about a severe trouble of his own. He saw the doctor, who examined him carefully, prescribed for him, and told him when to letum. This care and ministration went on in the case of the suffering pastor for well nigh two years, until, through the blessing of God and the skillfin treatment of Dr. Agnew, the minister was restored to perfect health and strength. Some little time alter his recorery the cleroman wrote to Dr. Agnew, athing lor his bill, and received the following remarkable and touching answer:-

-. Revbirexd axd Dear Sur: That I have heen permitted to mininter to your relief and. through the blessing of God on my efforts, have heen chabler to be of help to you, is a source of greatest gratification to myself. You owe me nothing. 'To your Master and my own I owe 
all things, and to serve one of His poor, suflering messengers is but a little service rendered to Him who gave Himself for me. All I ask is that yon pray for me; that is the richest return that you can malie.

" I am yours in Christian fremelship,

\section{". D. IITES AGNEW.'}

"Another minister present at the table said: "Well, I know a preacher who was tended by Dr. Jghew for norly a year, and when he was quite better asked the loctor what he was in his debt. With one of those kindly smiles that marlied Agnew and a gentle tone Dr. Agnew asked him: " How much do those people down in the country give you?" The preacher named a very modest salary. "Oh, well." said Dr. Agnew, "when they quadruple your salary come back and tell me and we'll talk about the fee.",

"I can myself testify that on very many occasions I lave spoken to him about some poor man or woman whose peculiar case demanded special advice, and I have never so spolien to him that he has not either gone to see the sufferer or had the patient come and see him, and it was all done with a sweet courtesy and a tender sympathy that showed that Dr. Agnew felt himself blest and honored in being permitted to help any of the deserving poor.

"His Devont Piety. - If there erer were a simple-minded, humble, devout Christian man, it was 1). Hayes Agnew. Ife was a man of prayer. For himself he felt and owned the need of daily and close communion with ciol. An arly riser, the first part of the day was consecrated to this fellowship of the Spirit with his Father in Ifeaven; and it was a rane thing, indeed, when he allowed the most sudden and rrent call. (renent an unusually early hour, to take lim firom his home without first bending at the fomily altar, and loading with cancest tone and reverent spirit and loving heart the thonghts of his family up to God, and secking for them the Divine blessing and for himself the Divine gutemes in his work and the help of the Great Physician in the discharge of his own profensional dutios. More 
than a score of times have we talked together upon the power and necessity of prayer to men living public, noisy, professional lives. It is the close hold of a man's soul upon the unseen God that malies him strong for duty and kindly among his fellows. That was a realization of Dr. Agnew's experience.

"He was a diligent student of the Bible. IIs habit for rour had been regularly and systematically to read through the cntire Word of God. This work was not done as a mere piece of routine. It was not done for the mere sake of doing it. He rad thoughtfully; compared scripture with scripture; searched the scriptures, and had the Word of Christ dwelling in lim richly. in all wisdom and spiritual understanding. If you made 1)r. Ignew a present of a book, there was no gift that he wolromed so ghaly and with so profuse thanlis as some work cating fresh light upon the Word of God. Travels in the Holy Lind. descriptions of Biblical life and customs, accounts of explorations maling more intelligible hints and references contained in the Ohd lestament, were all cagerly hailed by him and arefully studied. He was one of those who mertitreter on Godt's word. It was a rery common thing for him to have for his more intimate elerical frients a number of very difficult guestions in romection with the meaning of seripture, and as le would put the e to you you felt immediately that you were draling with a man who hat thonght very depply upon the mbjert presented to you for explanation. One of the last topies on which he and I ronversed together was the nature and meaning of the demoniaral possessions referred to in the New tortament.

-Hr. war a lover of the Sibbath. He did, indeerl, comnt it an homor and a delight, and resolutely and reverently set it aprat for yoritual rest and refreshment. As he himself said, he hart an abhormance of P Sunday physic.' He regretted exceedingly whenever necesity and the supleme all of merey required him to give up to profesional work and duty any part of the sacred hour of the Lord's Day. And with that quiet dignity that so 
strongly marked him when he chose to show it, he resented anything like an impertincnt interference with his quict cnjoyment of his time of rest and worship. The imner circle that knew him best knows full well the pained look that ame across his face when some one with abundance of leisure intruded himself upon the quiet, thoughtful, Christian man, enjoying the calm of the Sabbatic afternoon, to obtain advice that could just as easily have been had upon the morrow.

"He was a constant attendant upon church ordinances, and moming and evening his tall, ereet form was seen in the House of God, and from the begimning to the end of the service his reverent attention never faltered, and his manifest enjoyment was clearly written upon his countenance.

"His Settled Fuith and Conrictions.-He was a man of settled faith and of strong convictions. He knew what he believed and why he held his faith so fist. He had searched and tried himself in the realized presence of God. Te had carefully compared scripture with scripture. IIe had earnestly and steadily faced and fought his doubts and difficulties. He had groped through many an hour of thick-set darkness. IIe had plumbed the deep, sullen waters of perplexities and seeming contradictions. He had pushed his way through stormy seas of controversies, and the end of it all was: 'I know whom I have believed, and I am persuaded that IIe is able to licep what I have committed to Him against the day.'

"In the closing years of his life, his mind was at perfect rest in the clear, serene light of established trunt and conrictions, yet was he ever ready to face and fairly consider every new question reverently put and backed up with areuments of secming strength. During these past ten years not a single sulject of debate has come up upon the confeswional fickl. or within any of the great ecclesiastical lines, on which he and I have not talked frequently and filly. Ife had thomght anch one of them out for himself, and arrived at chean-ent and definite condusions. He rested implicitly in the Word of (iod. IIC was satisfied that 
when the lant fill word was spoken by science, it would be in acrord with the Mord of God, or, at least, in no antagonism to it. He held firmly by the unity of truth, full truth, simple truth.

". Is to his creed and church, he was a positive Presbyterian. Privately and publicly, with great gladness of heart, and yet with no offensireness. he arowed himself a lover of the old blue banner. Ile honored her history; he loved her simple ways. He delighted in the direct and mimpeded intercourse which she wave the sonl in her address to God and her mamner of communion with ITim and the seeking of His face. In the later questions, stirred within the pale of his own communion, he took a very lively interest, and held strong, clear opinions.

-Ihis Brourl Cutholicity of Spririt.-He was settled in his own convictions, but he was tolerant of the opinions of others, and eatholic in the true sense of the word. He loved his own chureh best, but was generous in thought and kindly in feeling toward all. He had many friends in all the churches, and in all the communions of Christ he recognized admirable features. He was intelligently acquainted with their doctrines, with their history and their forms of worship, and he recognized the good that was in each of them. Standing firmly upon his own Preshyterian fomblation, he said, from the depth of his heart: 'I beliere in the commmion of the saints.' He preferred the charareteristic ror hip of the chureh of his fathers, but felt by no means a stranger in any of the sanctuaries of his Christian brethren. Wherever the message of his Master came to him, he received it reverently and lovingly, no matter what mouth spake it or in what pernliar form of worship it found its place. Thus I recall him. the man who anthered unto himself and sweetly combined and hamonized so many moral excellences; the man of gentle spreceh and lindly spirit; the man of deep, humble pioty, of settlod faith and broad catholicity; and, as I think of him. I sec him in the hipply quiet of his summer lome, in the early hours of the Siabuth morn, with his open Bible by 
his side, wherein for a good, long hour cre I came upon him he had been reading; the still, serene light of a happly. restful soul lying softly on his comtenince, and the deep, calm joy of a Christ-kept spirit shining through his eyes, and the sugggestive, quiet speech of a God-tanght believer coming to me helpfully when I entered on the duties of the day.

"Once again I see him, a sick and suffering man, leaning back, weak, in his arm-chair; lifting his wasted hand to take mine, and raising his lindly eyes to me and thanking me for a simple prayer which, he said, 'has done me the most good. and has made my heart to rest.'

"Thus I bid him farewell, until the shadows flee away and the morning breaks for both." 


\section{CHAPTER XIII.}

The Jubilee of Dr. Agnew.

Ox the 10th of April, 1879, the confières of Dr. Gross, in commemoration of the fifty-first year of his entrance into the profession, gave him a complimentary banquet at the St. George Hotel, at which 1)r. Agnew presided. The number of subscribers was limited to one hundred. Among the invited guests were many of the most 'prominent surgeons and physicians in the United states. The Committee on Arrangements originally consisted of Drs. D. Hayes Agnew, Thomas G. Morton, and Richard J. Levis, to whom was afterward added Dr. J. Ewing Mears, as sccretary. The undertaking had its origin in the Surgical Club of Philadelphia, a private association which met once a week during the autumn and winter for mutual improvement and the cultivation of lindly feeling. It had been the intention to extend this compliment to Dr. Gross the year before, on the oceasion of his semi-eentemial professional birthday, but the celebration had to be postponed on account of the death of his wifi.

"P'roferior Annew' amnounced the first toast of the erening, 'Our (ine-t.' and. addressing Dr. Gross, indulged in the followinge cloquent strain, which wats repeatedly applauded during its delivery:-

"The lomer of speaking to this toast devolves mpon myself, and I ma! -a! that it gives me areat pleasure to he the melim of extending (1) you, on this aceasion, the friendly congratulations of your profes-

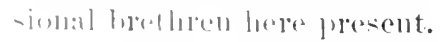

"liftrone years is long time, my dear sir, for a man to labor in

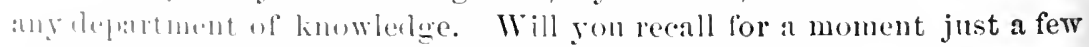

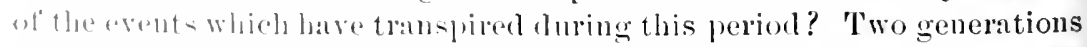
have playoul their part in the great drama of life, and have left the stage.

'The rematmine of the report of this banquet is taken from Dr. Gross' autobiography. $(\because)())$ 
Dynasties which bid fuir to rival in perpetuity that of Roure itself have risen, flomrished, and passed into decay. Engineers have struck their levels, aml laid down great iron roalways from one emd of this continent to the other, minting together the ratters of the Atanticand the lancific. The most distant palts of the eallh have been reached hy thicathis of iron, over which pass the thoughts ol men in chariots of electric fire. The

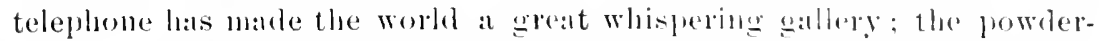

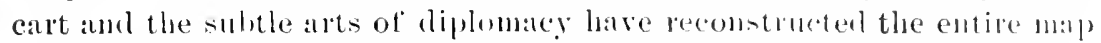
of Europe; and an American medical and surgieal literatme has grown up to which you have been one of the largent contributors, - a literature which is not only read on this side of the Athutice, but in every civilized comntry on the face of the globe. And get here youl still remain, my good friend, sturdy and stromg as a gleat oak of the forest; or, like Moses, with eye undimmerl and strength mabated.

"It is, I fear, too commonly thomglat, in these days of mad haste for preferment, place, or power, that men, when they have passed threescore and ten years, should gracefully retire to the shades of private and inactive life, learing the tield to youmere athletes.

"This is a great nistake. Look at old Plato, at oighty-one, delying away at his stulies with all the cuthusiasm of youtl ; at leorelates, alelivering his great Panathenaic oration at ninety-six. No. no! 'lere is something in the grace and dignity of ace. Its serene complaterncy of mind, when coupled with an alluent wealth of knowlenge and rich stores of observation and experience, remeles the prenence of old men in our midst pillars of strength, not only in a profession like our own,

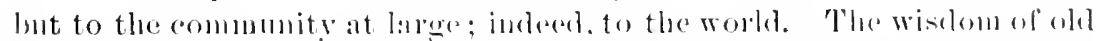
Fahius was mole than a mateh for the trabed legions of the pouthluland wily Hambibal. It was not for men like Milo, or Ajax. for which the Captain of all the Greeks prayed, an order that le might lumblule the froud hattlements of 'Troy, hut for men like Nestor. Long mal you pet live, my dear sir, actively to engage in the dutios of the profession which

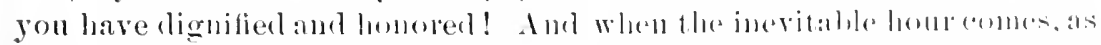
come it must to each and all of 11 s. - that supreme homr. on which all the

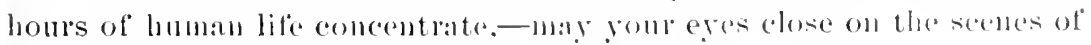

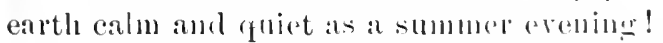

"It omly remains for me to place on the lapul of yom cont this little

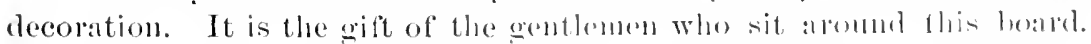

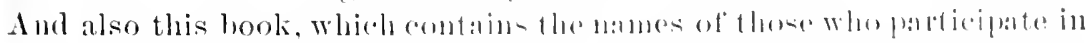

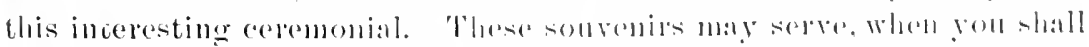
have laid aside the halluess of eonflict, to recall some pleasant mumolies of the past; and they may also fond lo line the ambition of your sons to emulate the ambition of their noble: sile. 
"When Profesior Agnew had finished his address, he attached to the lapel of Dr. Gross' coat a gold medal, having on one side the monogram, ·s. D). G.,' in diamonds and brilliants, and on the other this inscription: "Presented to Dr. S. D. Gross by his medical friends in commemoration of his filty-first year in the profession, April 10, 1879.' The memorial book, containing leares of tinted paper on which were written the names of the in rited guests and subscribers, was presented at the sallie time."

Nine years later Dl. Agnew celebrated his own jubilee; he had graduited ten years later than Dr. Gross, although he was thirteen years younger. In those nine years much had happened-Dr. Gross had died; Dr. Agnew had given up the larger part of his hospital work; he had cut down his practice, and was conchuding arrangements by which to retire from the University. It was the nine years filled with the most momentous rhanges in his life.

As the spring of 1888 approached, it was felt by the members of the medical profession that some public recognition slould be given Dr. Agnew for the completion of so long and so remarliable a professional career, for on a spring day tifty years before he had graduated from the University of Pemsylvania. For the purpose of carring out this intention. a preliminary meeting was leet in the Council-room of the College of Physicims. 'luesday. January 31 st. This preliminary call was signed by 1)rs. S. Woir Mitchell, Ellwood Wilson, John H. Brinton. J. Rolis Cohen, J. M. Da Costa, William Pepper, James H. Inutehinson, and Thomas.J. Yarrow. At this meetine. ledd Jannary 31, 1sis, on motion of Dr. S. W. Gross, Dr. S. Wrir Mitrhell was chosen chairman of the meeting, and Dr. Horace Y. Evans secretary. I)r. II. (. Wood moved that the form of the testimonial be a public reception; Dr. John Ashhumet. Jr., amended the motion, with the suggestion that it be made a banquet by the mombers of the medical profession, which was adopted hy rote. It was decided, therefore, that a dimer 
be given to Dr. Agnew, the subscription being fixcd at twelve dollars, two dollars of which and the balance that might remain after the dimner to be used in procuring an oil portrait of $\mathrm{I}$ r. Agnew, to hang in the hall of the College of Plysicians.

A Committee of Arrangements of twelve was appointed, which consisted of Drs. J. M. Da Costa, Ellwood Wilson, Owen J. Wister, Richard A. Cleeman, J. Solis Cohcn, Alfred Stillé, John Ashluurst (Jr.), William F. Norris, Samuel Wr. (iross, Lewis Rodman, William Pepper, James II. I Iutchinson, and S. Weir Mitchell. Dr. J. M. Da Costa was appointed Chairman of this Committee.

Dr. Agnew accepted the invitation of the committee, leaving the date of the dinner to be fixed by them. The committee accordingly selected the 6 th of April as the most appropriate date for the banquet. At its meeting on March 3d the committee approved a list of physicians to be invited to subscribe to the celebration in Philadelphia. It was decided that the plysicians outside of Philadelphia to be invited to subscribe be limited to those living in towns in neighboring States, within a radius of forty miles of Philadelphia. It was resolved that certain physicians from other cities be invited as guests, as reported by the same committce. This list was afterward revised by Dr. Agnew.

The banquet was confined cutirely to medical men, with two exceptions, these being the pistor of 1)r. Agnew's church, Rev. D)r. John S. MacIntosh, and his consin, Rer. Dr. Benjamin L. Agnew. More than two hunded physicions promptly accepted the invitation of the committee, and the banquet took place, on the evening of the appointed day, in the foyer of the Academy of Musie. One table was placed paralled witl the northern wall, at which sat the chairman of the committee. 1)r. J. M. Da Costa, with the honored wnest of the evening, I)r. Agnew, on his right, and the liev. 1)r. Machutosh on his left. Three long tables at right angles to this reached nearly to the southern end of the room. 
It no period in his life was there a greater display of the magnetism which surromeled Dr. Agnew's personal presence. Ilis modest manner only seemed to heighten the enthusiasm and love havished upon him by his colleagues and former students. 'These characteristics brought out one of the most curions features of the success of $\mathrm{Dr}$. Agnew, - the remarkable lack of ill feeting and jealonsy which surromeded his advance. Although the attendance at the banquet was male up largely of his lifelong associates in the medical profession, there was no one to begrulge his honors or belittle his fame. It was demonstrated to the public again that 1)r. Agnew was truly, as was said of him later, "the doctor's' doctor."

The opening speech of the evening was made by Dr. J. M. I) il Costa, who proposed the toast, "The Honored Guest of the Evening." He spoke as follows:-

Fifty years ago, on this very day, there stood, with the honors of a Univerwity juat received, a yomm man on the threshold of his life. Ilis thoughtw were the pleasant ones of the occasion ; his aspirations had

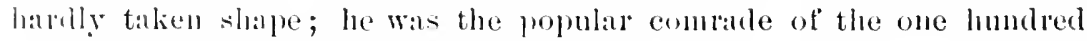
and fifty-live whose real life, like his own, was to begin. Fifty years lave passed, and their Agnew has become our Agnew, of the many thousindis of the medical profesion.

Hommed Guest: In addressing you to-night I feel that I speak not simply for those who are gatherenl aromel you, nor for those in this Commonwealth whe interests will eentre here, hit for the whole proferinon, who hold pon in such esteem, and whose sympathetic thonglits, enuld they reately gon, would come to pou in messares of such good will and allioetion ats to overwhelm youl with their warmth.

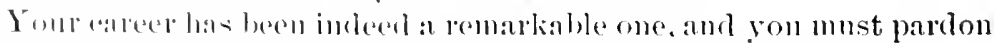

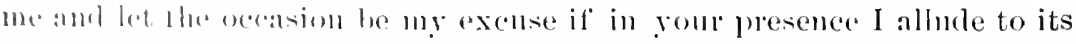

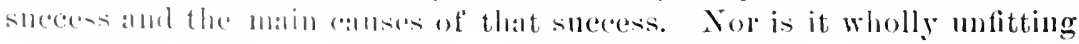

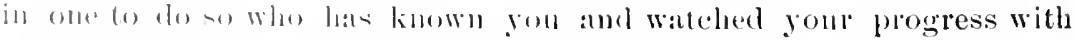

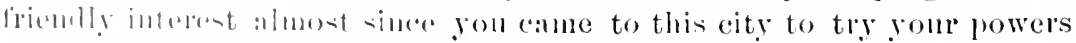
in a wiler liakd. The training you hrought with you as a rual practi-

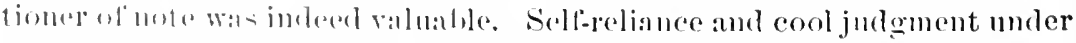
diflicult cincrum-lances are not the least reward of a combtry physician's hatred life.

You enrolled yourself as a teacher of medicine in its most labori- 
ons branch, and fittingly took charge of a school which has heen the nursery of famous anatomists and surgeons, - where fooman's plactical skill was displayed, and Joseph Pancoast laid the fommlation of that intimate knowledge of the human f'rame which mate him alterwad so great a surgeon.

The Philatelphia School of Anatomy, in College Aremue, has, indeed, left its mark in the history of medieine. It has heen to us what the W.indmill Street School was to London, of William and John IInnter, of Hewson, of Cruikshank, of Baille, of Benjamin Brodie, of Charles Bell. Its rickety structure harbored not only anatomists, _some of them your own pupils, who are to succeed you as celehrated teachers, but its dingy walls heand eloquent discomres on direrse blanches from more than one of your future colleagues. In its garret, independent and fruitful researehes on the textures of the borly were pursued; in its eramped lower room, physiological experinents were carried on, which bave made their deep impress on the science of our day.

For ten years, working in this school of anatomy, you lived laborious days and nights, and in its stem training your elasies grew until the narrow quarters would hold them no more, and yon hecame the popular, admirable teacher you have poved yourself nu a langer scale and on a different branch, as professor of the principles and pusctice of surgery in the famed Unirersity with which your reputation is forever identitied.

You learned to present facts plainly and impressively, to teacl nature's truths with mature's simplicily, and without a deadly paralysis of words. But in these ten vais of numitting work rou did something more than teaching,-you laid, by exaet knowledere, ly stouliness of purpose and atfability, the fomndations of that lare pratetice which you have since enjoyed, developing more crepry day into the trusted surgeon, whose deft hand and cool judgment camsed his alvice to be geverally sought.

You have been tried in many a hard ase; in none landel than when

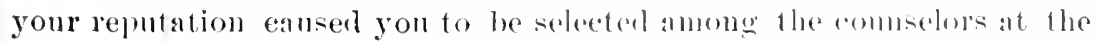

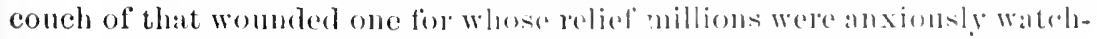

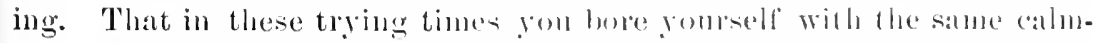
ness and dignity we know in you, every one in these millions lenengized.

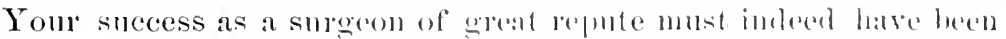
gratifying to you; not only for fle opputumities it allomber pou of

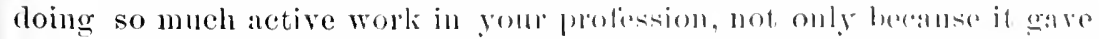
a personal value to your witings, especially lo your opinions expressed in your elabolate work on surery, hut beanse it enablat fon to carry ont a plan of action of which I ma not speali, -one which showed you 
to be prencereet of the same high sense of honor for which Sir Walter seott has receiver the mboumled admiration of mankind.

Maty yon, dear sir, who have these many elaims to distinction and esteem: Maty youl on this the filtieth amiversary of entrance into a profession which you have graced by your industry, your siugacity, your skill, your challacter; maty rou atecept the homage of those who are entalgerl with you in the sime pursuit, as a sign of widely-felt regard and appreciation. May your vigorous frame preserve your power of doing good, of tuaching truths, for many a long year. May there always reman with yon the as-mance that, as age gently lays its hamd upon you, the chilling finger of time will not lessen the respeet nor benumb the tenderne-s of feeling with which young and old alike regard you.

At the close of the speech by Dr. Da Costa there was great cheering for some time, and, quiet finally being restored, Dr. Annew arove. This movement was greeted with enthusiastic cheers. IIe said :-

N18. Cimunuax: When I glance orer this table and see so many distinguished and representative men. of my own profession, who have eome to "lo honor to one of the humblest of their guild, I eonfess it is with a leep sense of embarassment that I wish to respond to the compliment:ury sentiment emborlied in your toast and in your address. I can say, whithout affectation, that, hat it heen the pleasure of my friends, a lese conspicuns demonstration of their good-will than the present woull have heen more in eonsonance with my feelings and taste.

It is a wreat distinction for any man, in whatsoever spliere of life lum mano mo to win the confidence and esteem of his fellows. And it is

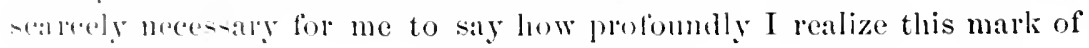

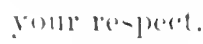

Aly man who has lived long in this world, and has taken a thomehtful retro-pect of his past life, must be foreed to confess that

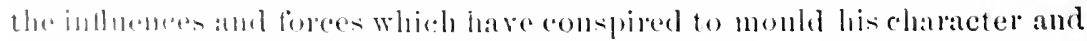

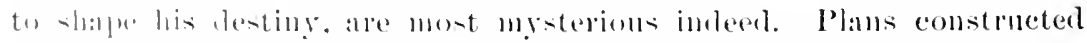
with intinte "are have mi-earled; fombly eherished hopes have been

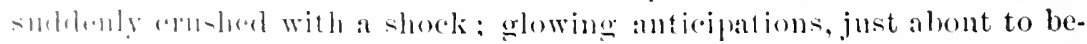

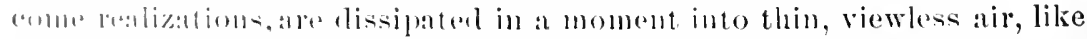

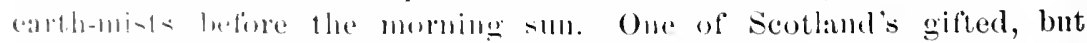
unfintmante solis, hat eomlensed these thonghts into the expressive conllet:-

"The best lail schemes o' mice and men Gang aft arlee." 
And the great bard of England-rather, the bard of all people and all times-has erystallized the same sentiment in those expressive lines :-

\footnotetext{
"There is a divinity that shapes our ends,

Rough hew them as we may."
}

And a greater than either has said: "It is not in man to direct his steps."

Abont thirty-five years ago, I came to this city a stranger. Althongh previonsly enjoying a large practice in a wealthy and populons district, yet the field was never a satisfictory one. 'The horizon seemed too contracted, the prospect uninviting. Possessing naturally strong anatomical taste, I was able to ratify these only to a moderate degree, by dissections of the human body and the bodies of animals; the prejudice against studies of this nature was calculated to render their prosecution unpopular, not to say very embarrassing. The desire, therefore, to obtain a larger field for the gratification of the idol of my thonglits induced me to make P'hilatelphia my home.

The scene of my eally labors, as most of you know, was in College A venue, in the Philudelphia School of Anatomy. 'This inctitution - not a chartered, lut a private one-lad both an ancient am an honorable history. It was here that Godman and Webster and the elder Pancoast and Allen laid the foundation of their reputation. It was, indeed, a sehool of the prophets; a gymuasium in which were trained the great majority of the men who, as teachers and writers, have filled so large a place in the modical world. Among these names may be mentioned that of Gerlard, the pioneer of plyysical diagnosis in America: of Wallace, who became Professor of Obstetries in the Jetherson Merlical College; of Bridges, Professor of Chemistry in the Philadelphia School of Pharmacy ; of Keating, elected Professor of Obstetrics in Jefferson College, but compelled to resign on aceonnt of ill health; of IIenry II. Smith, Professor of Surgery in the University of Pennsylanial of Francis Gurney Smith, Professor of Physiology in the same institution; of your honored ehairman, Professor of the P'rinciples and Pratice of Medicine in the Jefferson Medical College: of Penrose, Protessor of Obstetries in the Unirersity of Pennsylrania; of Brinton, one of the Professors of Surgery in the Jefferson Medical Colluge; Gatretson, the author of a popular work on "Oral Surgery"; and of Keen, l'rofessor of Surgery in the Women's College of Philadelphia. It was here that Brown-Séquarl delivered his lectures on operative physiology and it was here that Mitchell conducted his elassie experiments on snake-poison, and on many physiological problems, which have placed his name alongside that of Ferrier and given him a high place among the scientists of the 
present day. It was in this institution that for many years, summer and winter, night and day, rancly taking a vacation, I studied the mysteries of this womklertul organinm of oms, with a love and a zeal which nerer flagred, and drew allomil me, notwithstanding the hostility of the two great melical schosh, fiom a small beginning of nine meelical students, the landent private classer-only limited hy the capacity of the

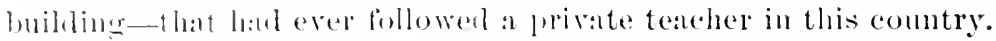

Those were happly diys: yos, I think the happiest days of my life. I was master, then, of my own kingelom. Those oki, dingy rooms load mole attratetions for me than the frescoes and fretted walls of a palace, and those anatomical odors were sweeter firr than those of Araby the blest.

Whan I was imbuced to aceept the Demonstratorship of Amatomy in the Iniversity of Penn-ylvania, it was with reluctance and regret that 1 left the old Philadelplia solnonl of Anatomy. It was entirely natmal

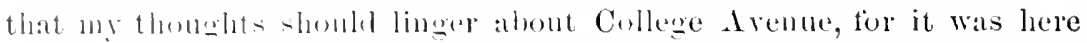
that I formeri those foremh-hipe which, like looks of steel, have bound ne to the merlical men of every part of this combly, and to not a few acerentheseat.

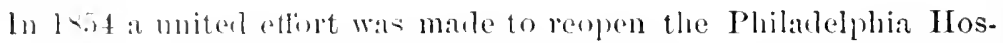
pital for medieal teaching. 'The doors of this institution hat been

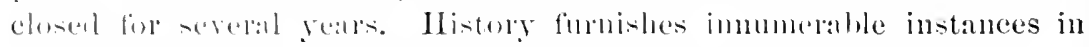
which the mot momentous events lase bern determined ly the most

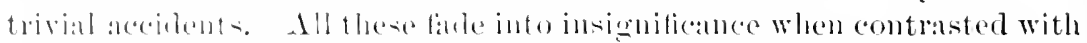

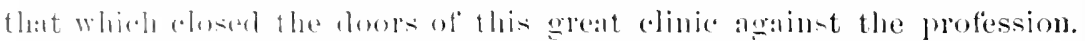

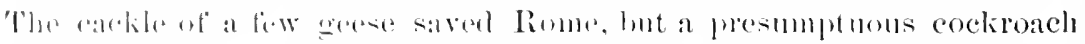

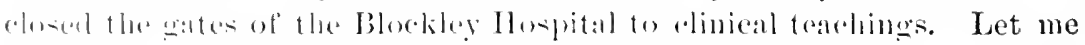

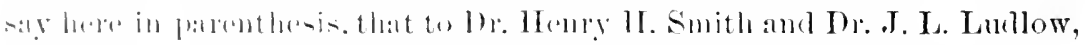

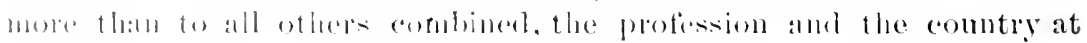

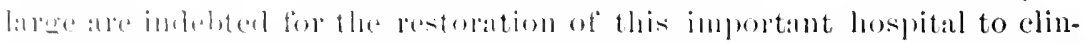

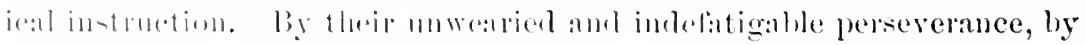
their murature importmity, like the wirlow with the mujust juclge, these

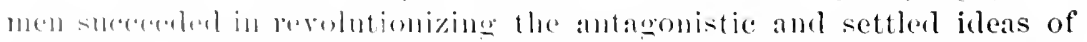

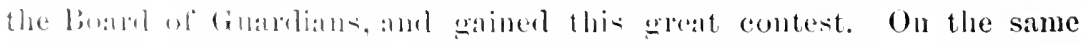
la! that the Ilw-ital Committee mate their firoralle report, Dr. Smitl

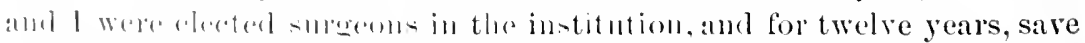

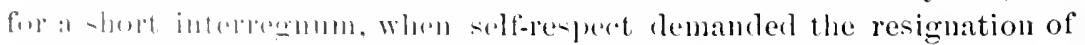

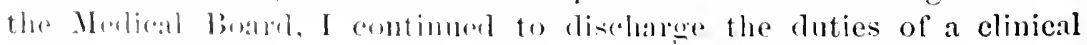

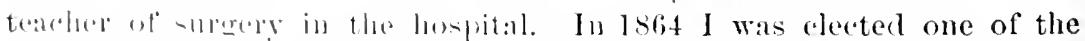

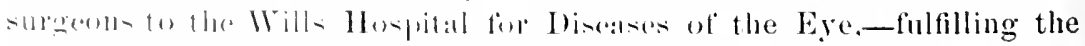
dution of the pripsirem for a perien of six reats. In 1865 I was honored by an alpuintment on the surgieal stati of the Pennsylvania Hos. 
pital, and for alout eleven years continued my sorvice in that venerable institution until the inauguration of a policy which compeller me to resign.

Let me say here that I have tried to malie it al rule of my life never knowingly to violate my sense of duty. Ant, with the help of God's graee, it has never cost me one moment's lesitation to turn my back on any proposition or place, howerer tempting, the aceptance of which would compel me to surender my conscientions conviction of right.

In 1877 the Board of Managers, of its own motion and nusolicited, with a cordiality and unaminity which I (an never forent, re-elected me to my former place on the suloical stall. In lsci I was elected one of the surgeons to the Orthoperdic IIospital, then situater on Ninth Street, which has now grown to be one of the important institutions of the commty for the treatment of aformities. In 1570

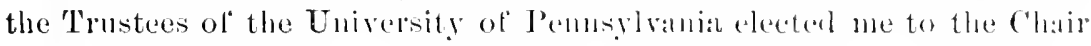
of Clinical Surgery in that institution, and a gear later te the Chatr of

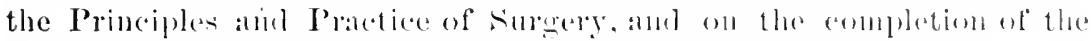
University Hospital Building I was appointed one of the chindal purfessors of smrerery.

Why I should have all these homors thus upon me I do not know. (A voice: "We know.") Othel aum ables men combl have filled them.

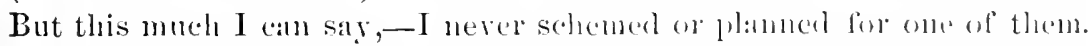

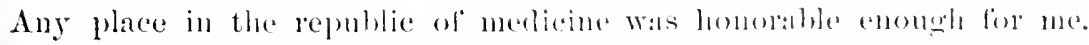

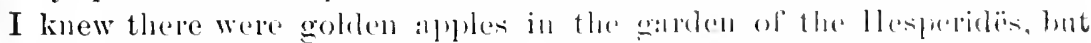
I was too much in love with my own particular study to attempt to play Hercules and the Intagon.

My love for the polession was inborn, wought juto the very fibre of my mental organization, and inspired not by the honors at her con-

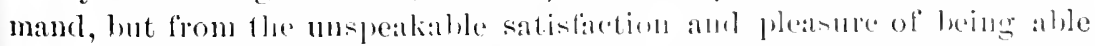

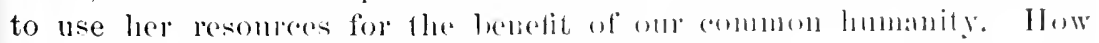
long I may le alule to eontinne in this sorvice 1 know mot. This I leave

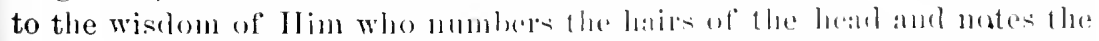

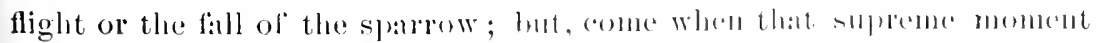
must, I shall be satistied. I have hatd all that l conld wish, - more than I deserve.

And now, gentlemen, this is a ereat. lomor which gon have dome ne; to be the guest of suclu a complum shombl sat is ly the most exacting

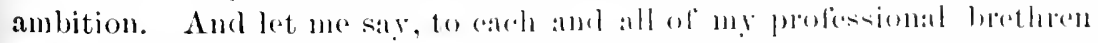

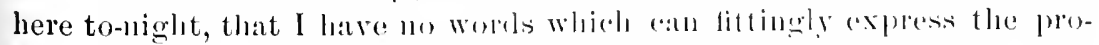
found obligation under which I am placed ly your generosity and lindness. 
1)r. Lewis 1. Sayre, of New York, being called upon by I)r. 1) (onta, spolie as follows, in response to the toast, "Our Invited Guests":-

Mr. Chambax and Gextlenes: I very fully appreciate the distinguished hmor conterred upon me by being requested to respond to the tuant of "Onr In rited Guests" on this momentons occasion, when we have assembled to commemorate the fiftieth anniversary of the profirsional life of one of America's greatest living surgeons, Dr. D. Hayes A wuew. I most sincerely regret that some one more worthy, or at least more competent, lawl not been selected to perform this pleasant duty.

There is no phyrician-and particularly no surgeon-in the broad expanse of this whole comtry who would not most thankfully embrace the opportunity of adding his leaf to the "laurel crown" so riehly earned by our distingui-hed friend, and which, to-night, we so cheerfully accord to hill..

Why is it that, withont a single dissenting roice, the entire profession of this rant eonnty mite in hamony with us in doing honor to Dr. Amew? Many others have lived and practiced the protession for more than filty rears. and yet have not heen singled ont for this distinction. Why is it. then. that this large gathering of the most distinguisined menleers of om profession. and from the most distant sections of our val territory. hak assembled here to-night to do him honor?

It is herance of his pure and monsulied life, his strict integrity,

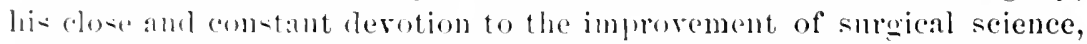

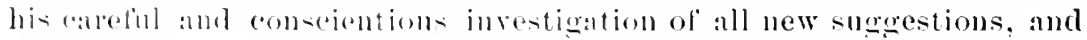
his realy apporo:al and aloption of all such as he could prove to be true, alter $\rightarrow 11$ h hill wertigation.

Another great cham of his character-aud which has endeared

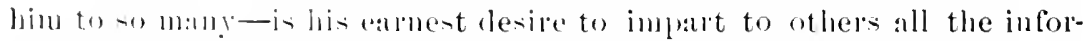
mation that he har whtained him-elf by diligent and eareful application. And he thut harame the disesminator of important knowledge to the thomsanshof sturlents who bistencel with rapture to his eloquent and in-

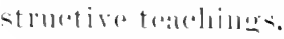

This in wot the fitting tine nor place to review in cletail the immense impurament-in livet. I might almost say the marelous improvemonts-that have ben male in the seience and practice of surgery "ithin the pat hall-century. Yet. I camnot reflain from briefly referrimer to a few.

T'ilie, for in-tance, the eases of compoum comminuted and compheated fincture that were formerly conclemned to amputation, and that ale now successfully treaterl, resulting, in many instances, in useful 
limbs and also in movable joints. Womnds and injuries of the intestines, bladder, kidney, liver, and even of the stomarls, whieh were formerly considered necessarily fatal, are now, by proper antiseptic precantions, snceessfully treated, and, in many instances, with rapid recovery, without any constitutional disturiance, or even the formation of a drop of pus. The exact localization and sucessful removal of tumors and abscesses of the brain; the union of all wounds by first intention, under proper antiseptic precautions,-these are some of the marvelous advances in surgery which, had they been described fifty years ago, would not have been believed.

But our distinguished friend, in whose honor we are assembled here to-night, has kept himself well abreast with all these recent improvements, and taught his recent classes the exact science of surgery, as unclerstood and practiced at the present time.

His has been a great gift,-the gift of the mastery of the mystery of healing; the wielding of the necromancer's wand over hodily deformity and suffering; and the still greater gift, the ability to impart to others, through his instructive teachings, the linowledge he himself possessed.

Our Divine Master, who commanded, "Visit the sick in their aflietions," He who made the blind to see, the lame to walk, the deaf to hear, the dumb to speak, appears in this eapacity in His very sublimest character, that of the "Great Physician,"-the ideal Christ,-Christ, the healer.

And surely, no other comes quite so near the wreat exemplar of Christianity as he who most successfully relieves hmman afllictions.

This, so far as I understand the character of Dr. Agnew, has been the principal or leading olject of his life for the past filty years.

Let us all imitate his noble example.

Dr. S. Weir Mitchell then read a poem in honor of the occasion. It was as follows:-

Poem by Dr. Nitchell. Read at the Ilinner Commemorative of the Fiftieth Year of the Dortorate of i). Mayes Llmmew, M.D., April fi, 1888.

Good Cinarman, Brotuels, Fribust, and Glests, all ye who come with praise

To honor for onr ancieut wuild a life of hlameless days, If from the well-norn roinl of toil I step aside to find A poet's roses for the weatli your kimlly wishes hind, Be certain that their franlance types. amid your lanrel-leaves, The gentle love a tencler heart in duty's chaplet weares. 
I can't exactly set the date,-the Chairman, he will know,but it was on a chilly uiglit, some month or two ago.

Within, the back-log wamel my toes; without, the frozen rain, storm-driven ly the angry wind, chatsherl on my window-pane.

I lit a pije, stirred up the fire, and, cly with thirst for knowledge, I'lumgen headlong in an essay ly a Fellow of the College. But, sis, I've often seen of late that this especial thirst Is not of all the raried forms the lieenest nor the worst. At all events, that gentleman, - that pleasant College Fellow, lle must hate been of all of us the juiciest and most mellow.

Yon ank his name, degree, and fame; yon want to know that rare m:!n?

It wan-11 you,-nor you,_nor you ; - no, sir, 'twas not the Chairman !

For minutes ten I drank of him, runenched was my ardent thirst, Another minnte, and my vins with knowledge, sir, hat burst;

A moment more, my head fell hack, my lazy eyclids closed, Aul on my lap that Fellow's bonk at ecqual peace reposed.

Then I remember me the niglit that essay tirst was reat, And how we thonght it conhdn't all have come from one man's head. At nine the College heard a snore and saw the Chairman start,A more as of an actor shy rehearsing for his part.

At ten, a slameless chorus aromed the hall had run,

The Cliaimam dreamed a feeble joke, and said the noes had won. At twelve the Treasurer fell asleep, the wakeful Censors slumbered, The seeretary's minutes grew to lonrs quite anmmulered.

At six A.M. that Follow paused, perelance a page to turm, A nul up I wot. and eried, "I move the College do adjourn." 'They dirlut, sir; they sat all day. It marle my flesh to creep. All night they sat ; that eonldu't he. Goorhess! was I asleep? Was I anteep? With less eflect that Follow might have tried

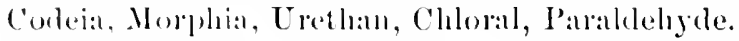

lu vain my servant a "alled alond, "Sir, here's a solemn letter T'u siy they want a song from you, for latek of some one better.

The C'hairman aly his man will wath while yon sit down and write;

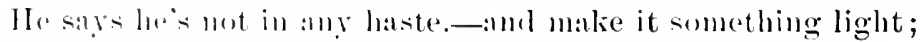
Ha say you needn't rex yourcelf to try to be elfulgent,

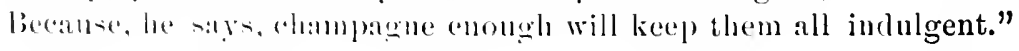
I selent -at leant I think I slept-an hour hy estimation, but, it' I selth. I must hise han unconseions cerebration; For on my desk, the morrow mern. I foume this ordered verse: I'ay talie it at you take your wife,- " "for better or for worse." 


\section{MINERYA MEDICA.}

A golden wekling; ifty earnest years

This spring-tide day from that do satly part, When, 'mirl a learned throng, one shy, grave lad, Inalf eonseious, won the Mistress of onl Art.

Still at his side the tranquil gorless stoor.

Unseen of men, and clatimed the student hoy, Tonched with her cool, sweet lips his rudly cheek, And hade him follow her through gred and joy.

"Be mine," she whispered in his startled ear,

"Be mine to-kay, as Paré once was mine;

Like Hunter mine, and all who nobly won

The fadeless honor's of that shining line.

"Be mine," she said, " the calm of honèst eyes,

The steadfist forehearl, and the comstant soul, Mine, the firm leant on simple duty bent,

And mine the manly gift of selfecontrol.

"Not in my service is the harvest won

That ovilis the child of baster and of trade;

That stead! lamel, that everepity yime tomch,

Not in my lecping shall be thus remaid.

"But I will talie you where the galeat have gone,

And I will set your leet in lomon's wals:

Friends I will give, and length of combled rears,

And crown your manlood witl a nation's prase.

"These will I give, and more; the poor man's lume,

The anguished sufferer in the clutch of pain,

The camp, the field, the long, sarl, wating ward,

Wateh for your kimbly firce, mor wateh in vain

"For, as the sculptor years shall chicel decp

The lines of pity 'neath the brow of thenght,

Below your whitening hair the hurt shall read

How well you laumed what I my lest have taught!"

The busy lootsteps ol your toiling stand

Upon the noisy contury's sharp divide,

And at rour side, to-might. I sere her still,

The gracious woman, strong and temdereyed. 
$O$, stately Mistress of our saered Art,

Ch:mgeless and beantiful, and wise and brave, Full tifty gears have gone since first your lips

'oo noblest uses pledged that forehead grave.

As romud the boand onr merry glasses rang,

IIis golden-wedding chimes I heard to-night; We know its offopring; in a hundred towns

Iis pupil children bless his living light.

What be the marriage-gifts that we can give?

What lacks he that on well-used years attends?

All that we have to give are his to-kay,-

Love, honor, and obedience, troops of friends.

The reading of this poem was followed by an address by I). R. A. Cleeman. to whose energies much of the success of the banquet was due. Dr. ('leeman made a brief but eloquent speech preceding his formal motion to adjonrm, which was afterward withdrawn, at the request of the ('hairman, Dr. Da Costa, to give I)r. Thomas Wistar an opportunity to read his verses written in honor of the guest of the evening:-

Ode to Professor D. Hayes Agnew, M.II., LI.D., on the Fiftieth Anniversary of his Graduation in Medicine, April $6,1898$.

By Thomas Wistar, M.D.

The winter whiteness glorilies thy brow,

'The smmmer smoshine lingers on thy face;

Upon the heart the years have lett no trace,

Warm as it kindled first, we feel it now.

Here are and youtl alike hefore thee bow,

Each rivals each with every kindly art

Tor do suele lonor to thy head and heart,

As lirendly woris and one brief hour allow.

'Thy constint home is in the loving lieart,

sitill loved the most by those who know thee best.

As if the Truth had elamed thee for her own,

'Thy honest soul disrlains ald doubtful art.

by sucla a thou the worlel is richly blest,

For grood men rise from high example shown. 
There are who stand aloft before men's eyes,

Like crumbling eastles better seen afur,

Whose grandenr oft a nearer view would mar, -

Snch dire defect in seeming greatness lies.

The truly great beget no sad surprise:

Humble art thon and gracions to thy kind;

No loud pretense hetrays the little mind,

No affectation weakness mulerlies.

Hippocrates and Galen-conld they rise

From honored tombs and be with us to-day,

With kindred souls who speak the ages through-

The master-minds, the great, the good, the wise-

Glad woull they crown thee with immortal bay,

Beloved by all, because to all so true!

Transcenrlent master in thy noble art!

In moltal throes and danger jmminent

Thy skilled hand needs no other precedent.

Who, like to thee, can bid the pulses start,

Tears cease to flow and wasting fear depart?

When Garfield fell and horror filled the land,

A nation breathed when thon didst slow thy hand,

If not to heal, at least to soothe the smart.

Thon, too, art honored as a teacher great!

Benign, as on a lofty mission bent,

No secret does thy candid boson hold;

But free to all who on thy wislom wait,

A thirst for knowledge and with high intent,

'Thou dlost the riches of thy lore minfold.

Thongh grudging Fate preseribe a narrow bound,-

Though Genius does not kindle with its flame,

Or grant to scale the stary leight of fame

'To all; yet from thy higher ground,

How realy was thy big heart ever found,

At every lesser hother's call in need,

'To give, on the equal terms, the kindest heed,

Though to thyself no vantage should redound!

No empty praises lo we sing to thee:

Could weary hospitals thy goodness teh,

Conld combless homes thy benefits mofoll.

Glad from the skies would Love and Sympathy

With Earth's too sordid ehildren straightway dwell,

Drawn by the story, if the half were told. 
In vain do these too hurried numbers tell

The peaceoul trimmphe of thy lifty years

Vaiu

'llat all muhilien fiom on eyes upwell-

While lovingly we on thy virtues dwell-

Unless to us thy grand achievements give

Some quickining energy like thee to live,

Anl like to these in living worth excel.

The evening shadows lemgthen o er thy way,

Aromel thee falls a mila and mellow light,

surely from care thou neelest some release:

Well mayest thon rest while yet the lingering ray

Of sunset splentor wats upon the night,

And earth and heaven and thy own soul say "Peace!"

The photograph of each gentleman who participated in the Jubilee Dimmer of I)r. Agnew. was taken by the photographer, W. Curtis Taylor, and mounted in a specially prepared allum, and presented to 1)r. Sgnew as a sourenir of the oreasions.

This bronght the formal proceedings of the banquet to a close. althongh the melical men lingered long afterward to listen to the informal speerhes. and to shake hands with Dr. lenew betione he left the daelemy. At a meeting of the committee. Jeld 1pril 2:3. 1888, Drs. S. Weir Mitchell. J. H. Hutchimom, and s. W. (inoss were appointed the committee on the portriat. Bernhard Clule was selected as the artist, and the splendil picture which he produred. and which hangs in the

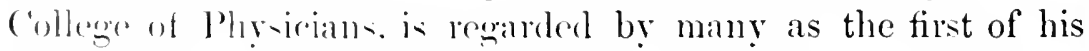
masterpiere. In. S. Wrir Mitchell made the presentation - puech. and the pirture was received by Dr. Wr. Wr. Keen, on Wollalf of the ('ollege, at a dinner leeld April 2:) 1890. Thus was rom-1ummated a mot hrart-felt tribute to a great man, beloved by his rolloagues, and without an enemy in the profession which he had made his lifr-work.

() 11 pril 19. 1890. when the committee met to settle its 
affairs, it appeared that a large surplus remained. It was then resolved that the balance of the find be expended for a portrait of Dr. Alfred Stille, provided that disposition of the money seemed appropriate to Dr. Agnew. Such disposition was sanctioned by I)r. Agnew, and the fine picture of Dr. Stillé was painted by the same artist, Uhle, and hangs near the portrait of Dr. Agnew in the hall of the College of Physicians.

On April 2t, 1888, the Faculty of Medicine and the students of the Medical Department of the University of Pemsylrania, held their celebration of the fiftieth anniversary of the graduation of Dr. Agnew. On this occasion the excreises were held in the Chapel of the University. A reception consumed the early part of the evening, and at 9 o'clock Provost Pepper, of the University, made an introductory speecll. 1)r. Pepper then introduced Professor Samued IT. Gross, of the Jefterson Medical College, who made an address, taking the carcer of Dr. Agnew as an object lesson. He conchuded by saring: . In Fngland they call Gladstone the Grand Old Man ; to me, Agnew is the Dear Old Man. Long may he live to adorn our profescion; long may he live to shed additional lustre upon the institution with which he is connected." Nilliam R. Iincoln, of the Class of 1888 , followed with a speech appropriate to the occasion, and in behalf of the undergraduates presented I)r. Agnew with a gold medal as a souvenir of the occasion.

1)r. Agnew then replied to the remartis which had been made. He pointed out the fiuct that 1)r. Leidy and himself were then the only links that connected the old Lniversity with the new. IIe then spoke earnestly to the students, and in tum addressed himself to the Faculty and Alumni, and urged them all, in his characteristic style, to use their hest cudrasors to further the interests of the Liniversity. The procerelings inchuded a banquet and songs by the Eniversity (ilec C'lub. The committee in charge of the banquet. selected J. II. Adams, of the Class of 1589 , to write a song suitable for the occasion, the 
music to which was the work of Ingh A. Clarke, Professor of Music at the Lniversity. It was as follows:-

$\$ 0 N G$.

Fifty years of strong progression!

Half a century of rise!

Noblest in al great profession.

Highest far, ly all confession,

But gentle, as thy name implies.

In the midst of Time's swift eddy,

Franght with wrecks of human life;

Thy figure stands out strong and steady,

For thy duty, calm and ready,

Never blinded by the strife.

The lone cripple in the aller,

For thy skill, holds life more dear;

And thy students, as ther rally,

Bless thee now from hill and valley,

Indian jungle and wild frontier.

When the Learder of the nation,

Low was laicl by insane will;

From the wide-spreal constemation

Grew the patient resignation,

Trustiug to thy mateliless skill.

With swelling hearts, we meet thee,

Thou, the gricles of om way.

With loving awe we treat thee,

With hmmblest prime we greet thee,

On this, the natal day.

Before the banquet each gentleman present was invited to recrister in a laree memorial allum. which was presented subsequently to I)r. Agnew.

It was regretted hy many non-professional friends of Dr. Annew that there was no demonstration paid him in which they (omlal take part. The demonstration paid Dr. Agnew by his follow-phy-irians was a most remarkable display of admiration. appreriation. and love which was decply and fully appreciated by him. and which had a marked effect upon the public, but many persons in other branches of life expressed a great 
desire to join in some celcbration to his honor. The possibilities of the magnitude and note of such a gathering cam be estimated when the interest of the public, as manifested in his death and funcral, are considered. 'This complaint was rendered partly unjust by the action of the Penn ('lub, which gave a reception for Dr. Agnew in April. 1888. By this means a large number of distinguished Philadelphians were enabled to meet and do him honor. 


\section{CHAPTER XIV.}

\section{Dr. Agnew's Retirenent from the University of Pennsyltania.}

Is contrast with this jubilee banquet was the last didactic lecture delivered by Dr. Annew at the University of Pennsylrania, 1 pril 5. 1889 . This lecture was probably one of the pleasintest and pet saddest experiences in his long career. To understand his emotions we must know the circumstances surrounding the occasion.

The jubilee dinner of the year before lost much of its saddening influences through the warmth of the enthusiasm and love displayed, throngh the flood of pleasant memories that poured their mellowing influence orer alt, like the beanties of a glorions sunset; but. like the sumset, the banquet was simply a grorifiation of the present; it showed nothing of the future.

This last lecture, on the other hand, was the quiet, practical scparation of 1)r. Annew from the most loved portion of his life-work. His chiefest energies had been expended in teaching. Ite had been an actire teacher for 38 years.

As has been shown in the chapter on Dr. Agnew's conneetion with the sichool of lnatomy, he delivered, while connereted with this institution, orer 1800 lectures. As Demon- trator of Anatomy at the Lnirersity of Pennsylvania, a rough calculation shows that he must have delivered at least 600 lectures while holding this position. In his position as Proferwe of Surgery he must have delivered at least 2000 lectures, incluling his cliniques, malking a total, at the University, of about 2600 lertures.

1)uring his ten years' service at the Philadelphia Hospital, and twelve years at the Penmsrlvania, he delivered, probably, $60(0)$ more. malking a srand total of 5000 lectures. In the thirtyeight years that he lectured, thicre were, on an average, 310 (318) 
working days, making a total of 11.780 kiys. 1)l. Ignew's rigorous application to his work is shown when it is seen that he lectured on 5000 days, or nearly every other disy. inchuding winter and summer vacations, holiclays, ete. for 38 years. No better commentary on his application to work than this exists, and, yet, this was only a small portion of his daily work.

In the lecture, which is included in this biograplyy. there are, approximately, 3000) words. As each lecture was about fifty-five minutes long, while this last one was only thinty-five, it is but fair to say that he used about 5000 words in a lereture; so that, in his lectures, he girre enough medical instmetion to fill a series of volumes containing $25,000.000$ words, which would make a fair-sized library, filling orer two humber volumes the size of this biograply. 'The mannitude of this service can be seen when it is shown that these leetures were delivered to about 12,000 students, who subsequently leeame physicians. As there are about 90.000 practi-ing phesicians in the United States, the extent of I)r. Aguew's forese at a latetor in medical education can be entimated approximately.

It made no difference as to the subject of his lecture; his audience at once perceived that he was not merely rehousing to them a lesson which he had himself just leamed for the oceasion, but that he was laying before them the results of pratetical acquaintance with his theme in all its bearings. l'osesing the happy faculty of being able to tell what he linew. impressing it on the minds of his students indelibly, he had spent the lapplyest portion of his life in this work.

He was now resigning from his profestorial chair not because he felt unequal to the work before him. but heranse he feared that such a time might come upon him mawares. As he said in his little speech at the rlose of this lecture, " (iod has given me the sense-the good scuse-to cuable mo to resign while I feel that I am yet in full cujoyment and posicession of all my faculties." He knew well that surgery is a crucl mistress; he knew that when her servants grow old, their minds 
less actire, and their fingers less nimble, she holds these failings up to the pitiless gaze of all. She does not permit that greatest gift of old age,- - the power to rest on the laurels of a life's work, to maintain the present by the memories of the past. On the contrary, she is as relentless to the old, tried follower of fifty years as to the newest tyro of to-day. This is one of nature's cruel but necessary provisions. Nothing earthly is as precions as human life; and when the operator grows unfit for his work, an All-wise Providence proclaims it widely. Dr. Agnew realized this hard side of his profession, and he stood more than ready to accept its conditions.

His students, as usual, singularly in full sympathy with his feelings, had decorated the lecture-room with flowers and plants. A wreath of laurel hald been placed on the central chandelier so as to crown, unconsciously, the head of their belored lecturer.

What risions of the past and future must have swept before the old teacher's eyes! 'There were memories of the dim long ano, when he had been a student in the old Ninth Street school. Then there were the happy days of teaching at the school of Anatomy, followed by the long train of years at the Lniverity. These were all now ended. Ife saw the future too clearly to delude himself with false hopes. He saw that he hat reathed the last great mile-stone in his career; and yet, except for : 11 occilsional hesitancy in manner and speech, and a certain subdued softness, nothing marked his ontward demeanor different from his wont. IIs long schooling in the repression of his feclings stood him in good stead. This modern gladiator, who hard fought the better fight for health and happiness, who land wrmer many rictories from discase and death, as hard fomplit ats that of Ifercules for the life of Alcestis, must have felt, an he gared on those tiers of benches, - so singularly suggestive of the old Roman arena and amphitheatre,-like the gladiators of old, ats they gazed on Chesar with the cry on their lips, "Thowe who are about to die, salute you!" 
So much has been written of Dr. Agnew's lectures that this last lecture is here incorporated. It was a short lecture,twenty minutes shorter than the usual length. IIe always spoke extemporancously, without notes excepting occasional memoranda of the heads of the subjects to be discrussed for the day. This lecture was reported stenographically. and is printed exactly as he delivered it, without additions. As he lectured, he pointed out the various anatomical points on appropriate charts and performed the various operations of tracheotomy on the body of a dead child on the desk before him. 'This ability to work and talk successfully at the same time is a most difficult task, but, as has been said, it was another of Dr. Agnew's accomplishments.

\section{TRACHEOTOMY.}

Last Didactic Lecture Inelivered by Dr. D. Hayes Agnew, at the University of I'ennsyleamia. Almil s, 18s:\%

"Tracheotomy is one of those operations that I think every medical man should be able to perform. There are two operations which, I have frequently said, every practitioner should qualify himself to do, in consequenee of the dinger which results from the loss of time. One of these operations is for strangulated hernia, and the other is tracheotomy; minutes comnt, and comt dearly, when any delay about operations of this nature ensues.

"The subject of tracheotomy is one that requires in the first place, a certain amount of linowledge of anatomy; a knowledge of the relation of the trachea to the two sets of great blood-vessels of the neck, and also to the arteries and veins which are placed immediately in front of it. A fow moments will enable me to call your attention to the leading anatomical facts in comection with this sulject. You will see nuon the blackboard a diagram which represents the trachea and the great vessels which croos it, or are related to it at the root of the neck, and also those which are placed npen its side. I Iere you have the arch of the aorta giving off, as the first blood-ressel, 
the innominate and then the innominate dividing into its two principal trumks, the subclavian and the carotid, and, on the opposite side, the carotid coming off as a primary ressel from the arta.

"Then, here is the trachea disappearing, crossed by this important rein, which is the transrerse rein, a rein which, when there is any difficulty in the respiration, often becomes distended to more than three times its normal size, and therefore is within reach of the knife when you are making an incision into the trachea, provided that the knife is carried down too low. Not only so, but you notice that a portion of the trachea is rovered up by the part of the innominate artery which is a little to the right of the median line, and, consequently. if your knife should run a little too far in this direction this ressel would be wounded. By keeping clearly in your minds the relations of these structures to the trachea itself such errors are not likely to occur.

" The trachea is covered by skin, superficial fiscia, and the platroma, and. joining in the median line, the sterno-hyoid and the sterno-thyroid muscles, with the deep fascia, and, next in order. the tricheal fascia. C'rossing the trachea, we have the thryoid body, which. in consequence of the great size of the midlde portion or isthmus, may sometimes interfere somewhat with the operation.

"There are various operations fone in the median line of the neck, all of which can be explained to you in a few moments if : on will look at the skeleton of the trachea and larynx.

"Alway pals yom biund orer the neck before beginning your opreration. הa as to malie rourself entirely familiar by touch with all the topographinal foatures. This you should do before liscecting any rexion, so as to notice clearly and distinctly all the swoll and depresions. Every part onght to be so elearly recognized that you conld produce a mental image of it at any time if you de-ired. P'iss rour hand down the median line of the neck and you feol first the hard body of the hyoid bone and 
then you feel the most salient portion of the neck, the angle of the thyroid cartilage; then, if you pass a little further clown, you come to another prominence which is not so large, but which gives you the idea of a dense ring; this is the cricoid cartilage. Now, if you let your finger slip down in the median line just below the thyroid, you will find that it drops into a little soft space which separates the thryroid from the cricoid,- - the crico-thyroid space. Below the cricoid cartilage you come to the receding portion of the trachea, the part which leaves the surface and sinks deeper in the neck, and which canses, an it drops beneath the sternum into the chest, this fossa which we speak of as the supra-sternal fossa.

"We come now to consider the operations which may be performed to open the respiratory apparatus. First, there is the operation which consists in opening the crico-thyroid membrane. This allows the free admission of air to the trachea, but it is not a space which gives any great room for removing a forcign body, or in which it is desirable to keep a tube for any length of time. It is only an extemporaneous operation to save a patient from perishing from a foreign body which may have lodged in his larynx, or when you lave not the instruments at hand to do a formal tracheotomy. The next operation is one in which you open below the cricoid; this is tracheotomy, whereas, the one higher up is laryngotomy, becmse it is within the limits of the larynx. 'These operations become necessary from a great rariety of causes. which I shall not stop to-diy to detail, but I will pass at once to the teclminge of the operation itself.

"What ressels are there which must be kept clearly in mind during this operation?

"First, if you perform the operation of larryotomy, - that is, opening through the crico-thyroid space. - there are four vessels, all coming from the crico-thyroid anteries. 'These divide each into two branches and schel one small trunk along the lower border of the thyroid and one along the upper border of 
the cricoid; sometimes these arteries are very large. Here, on this specinen, is one as large as the radial artery. If your knife were to divide that, you would have a furious hemorrhage, and if rou carried your incision far enongh to open the larynx the blood would probably enter and destroy the life of the patient. But rarely is the artery so large as it is here. Still, when you are opening this space, remember the existence of these two branches and make your incision exactly in the middle, neither too near the cricoid nor too near the thyroid.

"Then you have the other small branches which you meet with in pasing down the neck, but which are practically of little import muless you have present that ressel which is called the middle thrroid, or the artery of Neubancr, for the anatomist who first discovered it. It arises from the innominate, rarely from the arch of the aortal, and comes directly up on the middle of the trachea. Before any operation is performed, always examine by the tourch to see if you can find any pulsation there. 'This artery is sufficiently common to make it possible that you may encounter it in an operation of this character.

"At the root of the neek is a plexus of veins called the thryoid plexus. This preparation enables me to exhibit to you all the rascular parts that are of interest in the operation. Here gon have the erico-thyroid arising from the superior thyroid and supplying the crico-thyroid space. Then you come to this, which is the thyroid body, whose isthmus lies directly across the trachea covering in one, two, or three rings, and sometimes more of the trarhat itself. Then from the bottom you see this intricate plexus of veins, with very distensible walls, which berome very much disfended during the difficult respiration which areompanies (comp; so that often, when you have opened the nork and have exposed the tracheal fascia, you will be almost detered from inserting the knife among the large blue veins which cover it,-if you are not familiar with the operation. These voins run down and empty in to the transverse vein. Next you see the trachea covered in by the immominate artery, show- 
ing that it is quite possible to open it if the knifo is carried too far. I saw such an accident once. The knife was carelessly handled by an operator while opening the trachea, and he cut but did not sever entirely the innominate. The patient died, and I had that specimen for many years while I was tearhing anatomy; but it has disalpeared, like many other anatomical specimens, which, you know, are difficult to keep.

"Next you notice the transverse rein, which might be opened, especially if it was greatly distended on accomnt of difficult respiration.

"The great point in all operations here is to lice $\mathrm{p}$ accurately in the median line, for then it is not necessary to divide any muscular tissue whatever. Tou have this linca alba, you may say, or raphe of the neck, separating all the numscular tissues. If you go to one side or the otler and cut into muscular tissue, you become confounded and greatly embarrassed in this simple operation. I say simple, althongh it is not always a simple operation, especially in that class of ases on which you will usually operate,-childeen with short. fat necks, with a movable trachea rising and falling with each difficult respiration.

"The administration of an anesthetic is preparatory to the operation. Many cases clo not require it; the patient is in as.semiunconscions state and will malie very little resistance, especially when operation has been postponed, as it too often is. to so late a period that changes have probably taken place in the lumes, making the operation futike. It is well in ordinary cases to give the child a whiff of chloroform or ether:-chloroform often better than ether, because less likely to excite spasm and more kindly received by the patient,-enough, at least, to doaden the sensibility until you can complete that which is the sensitive part of the operation, namely, dividing the skin and subcutancons tissue.

"The instruments required for that purpose are, first, al scalpel, a pair of forecps,-the ordinary instruments that you have in your operating cases, - and a director, ligatures, and 
tenaculum; and then you are to be provided with such instruments as will enable you to keep the wound in the trachea patulous. We have various instruments for that purpose.

". This is the old tracheal tube, as it is termed. It is sometimes of metal, sometimes of hard rubber,-the latter is not reliable, as it is apt to be broken. This should be largely, if not entirely, a silver instrument, so as to keep it from tarnishing. It is simply a double canula with two shoulders, so arranged that you can introduce tapes or a little sticking-plaster,-preferably the former, -in order to hold it in the opening. One tube comes out of the other. You can disarticulate the inner tube by tuming it half-way around the object of this is that the tube may be kept perfectly clean. With a little serew at the top it is fixed in place. These tubes are curved, and the length of them must depend largely on the age of the patient on whom you operate.

"Then you want something to enable you to guide the cannla in after you have opened the trachea, and, very frequently, this is a difficult maneurre, and is sometimes the most difficult and cmbarrassing part of the whole operation. Your tube is apt to get to one side or the otlier, and it slips in between the tracheal fircia and the trachea itself, but, by introducing something that will act as an obturator and round off the rextremity of the ramula, you can usually get it in withont much difficulty; and -0 , in well-alppointed operative cases, you have this instrument which acts as a pilot. and, by its conical form, serves to combluet the canula into the opening. You can get along very woll.-and conomy is a great matter, especially with modical students and young practitioners, -as a rule, without any in-truments of this kind, by taking a soft catheter and passing it throngh the camnla till a small portion of it projects at the end.

"-Then you requive other instruments. For example: you may need a little dilator to expand the orifice you are making, in case you are operating for a foreign body in the trachea or 
bronchi. That you could do with a pair of forceps; but, still, this is a useful instrument.

"Then you require an instrument to take out foreign bodies that are in the trachea. Yon may introdnce this delicate, curved pair of forceps down till you reach the bronchial tube, if necessary, and take out a coin, for instance, which may be there.

"Then here is another instrument for which rou could very well substitute a feather or a camel's-lair brush. It is nothing more than some bristles twisted into a wire, which is meant to keep the trachea clear from the secretions which accumulate and tend to close up the tube.

"Here are two instruments which will sare you from what is always a dangerous thing to do, but which has been clone as an eridence of the boldness and self-sacrifice of surgeons, namely, applying the mouth to the tube and sucking it clear when the trachea would otherwise have been closed fiom the accumulations in it. Ilere is a syinge by which you can draw out the accumulations that are there, or by which you can kecp up artificial respiration, which is sometimes necessiry from the operation having been delayed so long that the prationt is practically moribund when it is undertaken. By forring in air through this tube, and then compresing the chest again, patients have been revived, by keeping up artificial respiration for some time.

"The retractors are these two instruments which rou see here; and now you have the whole armanentarium which goes to make up a complete case.

"The operation is done as follows: Have an assistant to take charge of the ether and give his whole attention to that. You may stand in one of two positions, either where an etherizel usually stands, at the haad of the patient. or you may take your position at the side and rut cither from below upward or from above downwarl. 'That is a matter of taste altogether. Then, if you are going to open simply the laryx for temporary 
relicf, you palpate and tonch the hyoid bone, the thyroid and cricoid cartilage, and then you retmon and sink your finger into the crico-thyroid space and immediately drive your knife vertically into the larynx; or you may pass it in transversely, which is better; or you may, if you piease, make a crucial cut. In this way you maly save your paticnt's life, though it is an operation of only temporary value.

"It is very easy to expose the whole laryngeal box by an addition to this operation which we have spoken of as laryngotomy. If the knife is turned on its back and you cut directly upward in the median line. you separate the two halves of the laryx and expose it and make it easy to remore a growth from the vocal cords or any other part of the larynx. Sometimes this portion. which we speak of as the angle, is so thoroughly ossified as to require either bone-forceps for clipping it, or the cartilage-linife.

- Put suppose you are going below and are going to open the trachear. for example, for croup. Then your incision should commence at the bottom of the thyroid airtilige. It is a great convenience to gire yourself ample space, so far as the soft parts are concerued, and so begin the incision that you will have a clear view of the median line and carry it down almost to the top of the stemum. The first incision should go down to the superficial fascia; then pick up the superficial fiscia. little by little, and divide, and then the deep fascia next. When you have divided the deep fascia, you have exposed at once the olger of the stemo-hyoded muscles, and then your knife is laid atede and you talie your director and pass it into the median line. whling up and down so as to separate these muscles.

" Son have divided no muscular tissue if you have been ardefisl to maintain the malian line.

"l'hen you come to the connective tissue between the stemo-thyroid mureles. Divide that and go down till you come to a boos facria. and in that perhaps you will see the reins bulging up rirectly inte the wound, and you must get rid of them. 
"Sometimes you can press them off with your finger or director sufficiently to enable you to get them ont of the way; but if you cannot there is no use tring them individually, lint you are to take them up in a bunch and put a ligature of catgut around the entire mass. Next, breaking up the tracheal fascia, I put my finger in and feet to sce if the middle thyroid artery is present. If it is not, I go on clearing away the loose connective tissue from the front of the trachea. which is another very important part of the operation, in order that the last steps of it may be successful.

"Many unsuccessful attempts to get a tube into the trachea have been due to the fact that the trachea hias not been reaned. If you have time, clean it till you feel your director rumning freely over the cartilaginous rings.

"Sometimes you are cmbarassed by the midalle lobe of the thyroid gland. Sometimes you can put the director under the whole isthmus and push it up, toward the thyroid cartilage. If you fail to get rid of the isthmus in that way. and it is often very rascular, you are to take a curved needle and palss it murler the isthmus, bring the thread out above, and allow a donble ligatture to remain, tying the isthmus on either side. This is valuable for another purpose, for you can stealy the trachea very much by these two threads; though we have another mothod of doing that. Pass the director nuder the isthmus and divide it between the two ligatures. After having exposed the trachea, the next point is to open it. It is well enough to have all hemorrhage arrested, though there is a certalin amomut of oozinin that will not be stopped by ligatures. but stops the moment you put the tube in.

"You must fix the trachea when you open it. An ordinary tenaculum is to be put in quiclisy, beranse the tracheal is moring up and down. It mily be neressary to have refractors to keep the wound open. Catch the tenaconhm in the collular tissue about the cricoid. Kerpe it stealy for a moment and lift it out of its deep sulcus. 'Then take a sharp-pointed bistoury' 
and make your incision in the trachea by cutting from below upward, for by so doing you are cutting away from danger. 'The linife is dipped into the trachea, and the dirision of two or three rings exactly in the mildtle line is made.

"When the incision is male, the next thing is the introduction of the tracheal tube, which goes through the wound in the neck into the trachea, and it may be secured by tapes or adhesive plaster, the tapes being better. Some put a suture directly through the sides of the wound and through the shoulders of the tube. This, however, is painful to the patient, and is a practice which ought not to be followed.

"Now comes a very important part of this subject, and it is the after-treatment. That treatment consists in having a shilled murse who shall be at the side of the bed-never leaving it for a moment; or, if so, she slaall be replaced by another of equal intelligence. Her duty is, with a feather or brush, to lierep the tube clear of mucus that constantly wells up into it and has to be wiped away. Not only so, but the temperature of the room is a matter of some importance. It ought not to be below serenty dergees, and sometimes it is better to have it a little more. 'Then there is need of something to prevent the intrusion of foreign matter from the air, and even the air itself is harmful until it has been modified a little by passing through some medium. Te usually take a little gauze and place it orer the tube. and we may moisten it with a little boracic-acid solution, so that the air is strained of its impurities and the lume ared from imitation. 'Two or three stitches are put in (n) rlose up part of the external wound and keep the tube in perition.

". T'he length of time the tube is to be retained depends very much on the morlid conditions that have existed before the operation. Ordinarily it is kept in several days, but somefimes sereral wecks. i very good way to tell whether it shomld be taken out is to place your finger over the end of it and compel the patient to breathe through the natural passages; 
and if he breathes with ease for a considerable period, it is time to remove it.

"These constitute the leading points in connection with the operation of tracheotomy."

After this lecture he addressed the class as follows:-

"And now, gentlemen, I have delivered the last of the lectures that it has been my privilege and my pleasure to deliver to yon. In taking my leave from the associations of nearly my whole life-time, I camnot do so without dwelling for a moment on the reflections that this occasion gives rise to. I have been connected with this Institution since its earliest days, through its rapid growth to where it stancls to-day, in the front rank of the medical institutions of the conntry. With a fecling of satisfation that I can thus hehold this Institution which we love so deary, I turn to eontemplate the retirement which I have songht,

"There comes at time in the life of every man when he wants to be free, when he feels that even the pleatint duties and congenial talsis which have heen his lot grow heary, - I have reacherl that time. I foel like the galley-slave, who, with manacles thrown off, hreathes the air of freedom. For over forty years I have heem. as they say in theatrical parlance, on the boards liefore the publice, and, an I grlance backwal over that long period of almost a life-time, three most delighthiul thoughts eome to me. The first of these is, that at no time hatre I erer becoll received ly any act of discourtesy or mkindnese by any of the whothen whom I have had the honor to address here (prolonged applanse). The second is, that the post of responsibility which it has been my cherished privilege to hold here was one that I had never solght. It came to me unbidden. And the thirl thonght is, that God hats given mo the sense-the good sense-to enalle me to resign it while I freel that I :11u yet in the fun enjoyment and possession of all my firculties. These I have endeavored to strengthen, to bromen, and to renter useful in the sphere of my professional life, for I feel that I liare lived to sery little atecomut if I have not lived to learm.

"In a few days we part, some of us, perlanps, to meet no more. How eagerly and reeply would I implese on your youl duties ats phy"sieians. Yon have chosen a profession which is one of the highest and noblest that a man can make his calling. See that, ly your firthlul zeal and application, you enlearor to maintain it in all the dignity that belongs to it.

"As we take this leave, I wish that all of you may" prosper; that it ma be your aim to elevate your lives and to romul them ofl in the full- 
neses of an underiating regard for duty and high purpose; that, in short, roll may be good men and true, good physicians, and pure, good, and homorable citizens. I trust, in the effort to attain these high marks in the life that stretches ont before yon, that you may contiune in a reverent regard for the firith that has sustained yon, guarded you from the praths of evil. I can say no more. God he with you."

No one realizes, until he attempts it, how difficult it is to talk to medical students in the strain as that shown by Dr. Annew in this little speech. IIc knew, of course, that the class represented the most diverse religions beliefs. There were all kinds and divisions of Cluristians, as well as Agnostics, Israelites, Persians, Mohammedins, Japimese, ete. To be personal and appealing without wounding their religions feelings is a very tactful and difficult task.

A few days later, at the One IIundred and Fifteenth Annual Commencement of the Department of Medicine of the Cuiversity of Pennsyrania, held May 1, 1889, at the Academy of Music, a painting of Dr. Agnew was presented to the University by the three undereraduate clasies of the Medical Department. It has been the arstom from time immemorial to present the portrait of a professor retiring from his department, to hang in the hall of the Wistar and Horner Musenm. This rollection has grown to be the most ralued possession of the Molinal Sichool, as was shown at the fire in May 1888, when the students, at the risk of their own lives, saved these paintings, althongh wamed by the firemen not to attempt such foollatidy risks.

'The invitution-carts cngraved for this commencement had in the enruer a representation of the head of I)r. Agnew, in honor of the ocrasion. Dr. Joseph Allison Scott, of the graduating rlase, in a few appropriate words male the presentation. "This

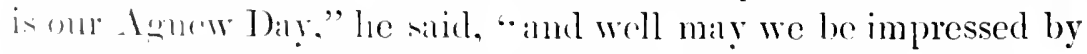
its solemuity for it is the last time that we shall see our belored proferesor before us in his official caparity."

'Then the veil, which had concealed the portrait, was 


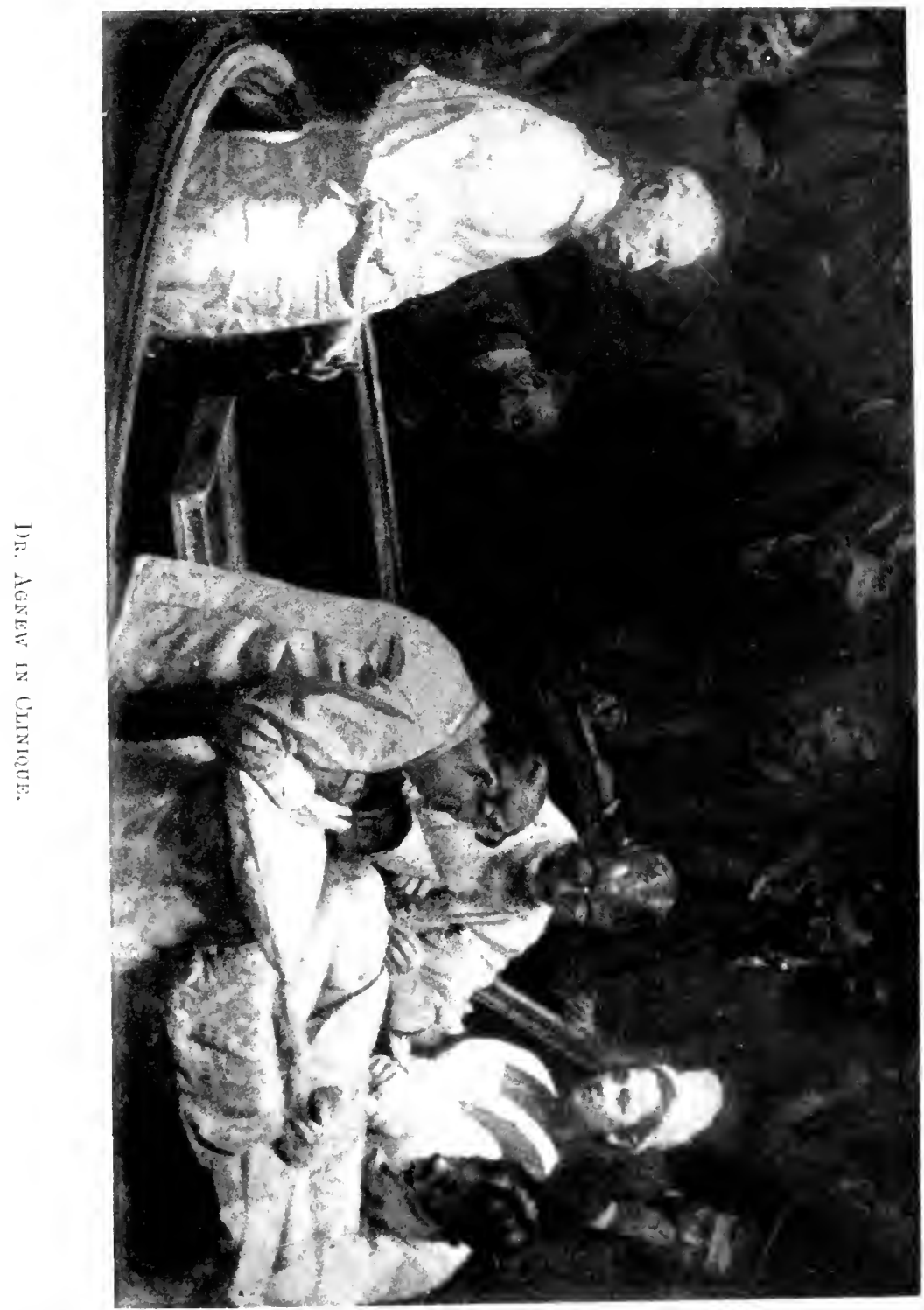


slipped off, showing a life-size likeness of Ir. Agnew standling in the clinical amphitheatre, laving just completed an operation,-removal of a cancer of the breast. All the fignres in the group were taken from life. IIis assistants are chressing the wound, while Dr. Agnew has stepped to the rail of the cliniqueseats and is explaining what he has done, and its motiomele.

The painting is seven by eleven feet withont the frame, and is regarded as one of the masterpieces of that famons artist. who has made a specialty of medical subjects, 'Thomas Ealkens.

The treatment of the subject is an amplification of the portrait of 1)r. Gross done by the same artist. The pirture incidentally shows an interesting change in surgery, the white garments of Dr. Agnew and his assistants being an innovation due to antiseptic surgery, mknown in Dr. Gross' time.

'This picture has been criticised, not for the ability of the artist, or for the artistic merit of his work, for the portrait of Dr. Agnew is as life-like as is possible and the delincation of the clinique-room is perfect, but for the idea embodied.- - that of presenting Dr. Agnew in the art of operating. While a surgical operation is rarely pleasant to a layman. and. consequently, such a subject must be more or less repulsire to the general public, yet at the same time it was this work which made Dr. Agnew famons. This picture. intended to be humg in the Medical School, is certainly not unworthy. as it represents the most important side of 1)r. Agnew's life-work; for its resting place it is perfectly proper.

While engaged in painting this pieture, the antist discovered forcibly one of Dr. Agnew's peruliarities. 1)r. Inow had been represented with blood attalded here and there to his hands; noticing this point. at once he objected most stremuously, and, despite the artist's protests for ficlelity to mature, he ordered all the blood to be remored.

1 The following is the inseription on the frame of the painting: "1). Hayes . Innew,

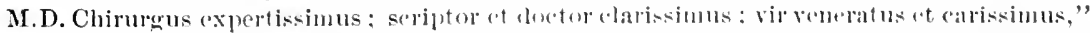
which, being translated, reads: "The mont experinced surgeon, the elearest writer and teacher, the man most beloved and venerated." 
The criticism is made that surgeons grow brutal, but here was a surgeon, who had been acenstomed to worling in blood for tifty years, who had not had his sense of propriety blunted in the least.

The portrait was received on behalf of the trustees by Dr. S. Weir Mitchell, Chairman of the Medical Committee of the Trustees. In a brief speech he accepted it in his usually happy style, concluding: " Whenerer you become involved in doubt and uncertainty, think what Dr. Agnew would have done, and You will be sure to have done the right thing."

When Dr. Mitchell sat down, there was a lond cry of "Annew" from all parts of the house. In response to the call, Dr. Agnew rose slowly and stepped to the foot-lights. This was the signal for a miversal burst of applanse and a deafening clapping of hands. When the noise had subsided, Dr. Agnew turned smilingly to his comnterpart in oil and said that thongh he had often heard of "speaking likenesses," this did not hold in the present instance, however cxcollent the representation, for he wonld be compelled to do the spealing himself. Continumg. he atid: "Perlaps yon have not all heard the story of the old woman who had spent her life toiling in a kitchen in London. Finally. being plared in a position to follow out her inclinations. she determined to free hersolf from all the tronble and turmoil of this life, and arecoldingly she built for herself a mansion onteide of the city. fitted ont with every modern huxy. But erery once in a while she became tired of her comforts and an mugovemable longing came over her, and she would rome barelis oreasionally to London to her old kitehen, to 'smell its greace.' So, now that I have retired into comparative eave. if life should berome unbearable to me. I shall still wain the (onnelation of going across the river occasionally to lexil the loow' vell."

It thi- I)r. Annew "heard the boys' yell" where he stoul. and surhe was the din that he was mable to proceed for several minutes. When the louse laad quieted down finally, 
he addressed a few words of carnest advice and cxhortation to them, and he was just turning to his seat when he staggered. A thrill of horror ran through the house, but he caught himself almost immediately, and before Provost P'puer, with his usual tact, could go on with the program, to conceal the occurrence, he reeorered his equilibrium and, tuming again to the students, said, in a firm, distinct voice, " I wish you all suceess in your profession." He did this to assure them that nothing serious had happened.

He had been suffering all the morning from a very arcute attack of indigestion, which brought on a consilerable amount of dizziness. This, with the glare and heat of the foot-lights orer which he was standing, the moving sea of upturned fares, and, possibly, with some natural cmotion under the circumstances, caused this momentary indisposition. It gare the students a chance to study that imperturbability of manner under the most startling circumstances which Professor William Osler, in the valedictory address a few minutes before, had declared so necessary in the young physician.

Dr. Agnew, by his resignation from the teaching force of the University, sought more time for leisure. It was his intention to derote less time to work and more to recreation. Is he said in his specele, he had reached the time when he wished to be free from the exarting duties of his life, and. morcorer. lis experience as a physician had tameht him that he had reached that time of life when he must matumally experet to leseen his output. Tis life became more sordial. he besan to spend more time with his family, and his home-life, which had been serions!y interfered with throughont his whole life, was now fuller and more satisfactory. I)r. and Mrs. Innew were able, at lengeth. to devote considerable time to rach othere.

Thus quictly and mostentationsly I)r. Agnew's life sperd on, broken only by such oceasional incidents as those junt related. He souglit rest more and more from his labors. although his nature and obliging disposition led him to work 
far more than he intended, and far more than he should have done. He found it impossible to slake off a large part of his work. He was still wanted at operations, and even if he would not operate many physicians wanted him present, simply to give his opinion and sanction as to the course pursued.

I). Agnew's reputation, at this period, had grown so great that it was no longer an honor for him to be associated with an institution, hut, on the contrary, an honor to the institution. By this time he had been made consulting or honorary surgeon to nearly all the hospitals and dispensaries in town, such as the Ginecein IIospital, the Kensington Hospital for Women, the Philadelphia Dispensary, etc.

In these later years Dr. Agnew took more interest in politics. II had been a life-long Democrat, although never active in political work. The rejuvenation of the Democratic Party by l'resident Cleveland aroused his flagging interests, and he eacerly watched and commended the beliefs and actions of this Democratic Moses.

A reprenentative from the University of Pennsylvania, who visited, in the course of his duties, a large proportion of the universities of Europe, had the curiosity to inquire of the different officials. pofessors, and students what men at the University

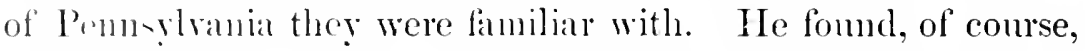
that in their own lines of work the different Emropean scientists were anduinted with the men doing that line of work at the Eniremity, but le found that there were but two men who were miremally known, and their career and deeds recognized and alpuesiated. There were Leidy and Aenew. Knowing that

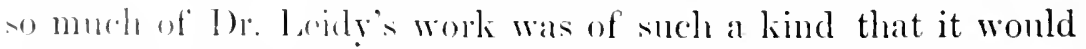
be distributed throunhout the edurated world. it was not a surprise to find hiv nane so familiarly quoted, but, as I)r. Agnew worlicel in a tickl and in a way which was naturally far more local. his constant perognition was rather surprising.

Curloubtedly. if J)r. Innew had gone abroad in the last few years of his life he would have received many honorary degrees from Emopean miversities, as did Dr. Gross. 
The degrees which he received were fow in number: as has been said, in 1861 he received from Princeton College the honorary degree of A.M., which was followed, in 187t, by the conferring of the degree of Doctor of Laws by the same institution. On June 6, 1888, the University of Pemnsylvania conferred on him the degree of LL.D.

Dr. Agnew's last appearance at a public meeting of any sort was at the Musical Fund Hall, February 27, 1892, on which occasion he responded to a toast on the professors of his youth, at the first triemnial banquet of the combined Alumni of the University of Pennsylvania. He found, when he began to speak, that his roice, which was usually so distinct, would not respond to the demand made upon it, and, although the hall has excellent acoustic properties, it was only by the strictest silence that his remarks could be heard. He spoke on a favorite topic,the outlining of the characters and areers of his early teachers. In such delineation as this he was peculiarly happy. Like the artist who, with a few quick, bold strokes of his peneil, gives the outline of a figure, in which what is left out is suggested, so Dr. Agnew, in a half-elozen terse phrases. could eteh the personality of one of these former giants. He felt rery much dissatisfied, after his speech, with what he had said, althongh to his anditors it was an unusnally interesting and absorbing narration. He was compelled, on account of feeling ill, to hurry home that night, directly after the delivery of his speech.

Judge M. Russell Thayer, who also replied to a toast at this same banquet, brought out a curious and beantiful coincidence in his own carcer, which applied unconscionsly, but equally well, to Dr. Agnew. The substance of what he said is as follows: "Fifty years ago I grachuated from the University" of Pennsylvania. The Commeneement exereises were held in this hall. During this long period of time the course of events has carried the University far to our westward, and for many years this old historic buikding stood alone and deserted in this rather disreputable portion of the eity. Now that the westem por- 
tion of the city has been built up, attention has been turned back agrain to this old site, and it has been rejuvenated, and our alumni banquet is held within its walls, and here I am speaking again in the hall which I left as a graduate fifty years ago. It seems as if the cycle of $m y$ life has been made complete and I have returned to the spot from whence I started, after a life's journey." 


\section{CHAPTER XV.}

\section{Dr. Agnew's Final Sicheses, Death, and Funeral.}

Dr. Agrew's death came as he desired it,-a quick transition from a busy life to an eternal reward. IIe found in later years that, after undue exertion on his part, he was subject to slight attacks of angina pectoris, due, as was afterward proven, to the ossification of the coronary arteries. If had, in the winter of 1889-90, a serere attack of epidemic influenza, from which he never fully recovered. Following this, he had an attack of broncho-resicular catarrh, of moderate severity. On several occasions he had passed renal calculi, and there had been slight manifestations both of diabetic and albuminuric conditions. On Wednesday, the 9th of March, 1892, after operating, he returned home at 3 o'clock. when, remembering that he had forgotten to see a case. he went out.

During this last operation, which he performed on this day, it was necessary to give him brandy a number of times, although the operation lasted but half an hour. Immediately after the operation, before he left the honse of the pationt, the attack became so severe that he became firmly possessed of the belief that he was going to die then and there.

On his retum home the second time, he was seized again with anginose symptoms, and was compelled to remain in his office for a number of hours before he conld be remored to his bedroom. For the next two or three dars he improved to such a degree that he saw several of his friends. In the erening of Saturday, March 12th, he became much worse. Itis condition from this time until the day of his death was simply a fluctuation from slight hope to positire hopelessness. During this time he was thoronghly conscious of his physical condition. and controlled largely the treatment of his case. On Sunday, March $20 t h$, he fell into a comatose condition, in which he remained 
until the moment of his death, which was at twenty minutes of three on the afternoon of March 22, 1892. The immediate rance of his death was uremia, due to the failure of the kiduers to perform their usual functions.

In antopsy was held on March 23, 1892, at which time there were revealed the conditions which had been diagnosed before death. Ite had met with a severe fall a couple of years before his death, and the members of his family were anxious to determine whether the injury at the base of his skull could be in any way connected with the diabetes which subsequently appeared. There was the trace of nothing abnormal in his brain; it was rather small in size, but the convolutions were mont tremendously marked and totally dissimilar in each lieminplere.

The American Anthropometric Society desired to secure his brain, that it might be placed in their collection alongside of that of I)r. Leidy. The object of this society is to place the study of the human brain upon a satisfactory scientific basis. (crobral topography is in many respects incomplete; brains of low. if not degenerate, type lare furnished, for the most part, the reults which have thus far been obtained. It is evident that this is not desirable. Knowledge should be drawn from -omeres which indicate, so far as it is possible so to do, the permliarities of brain-structure of all classes of society. Thile it is comparitirely easy to secure the brains of criminals and those who have been inmates of city hospitals, it is quite difficult to obtain brains of a higher expression of cerebral structure, and to stuly such with the aid of complete histories. To meet and orereme these difficulties, the society has appealed to the chlucated clinses for ansistance. They request the members of the ligher classes of America to bequeath their brains to the une of the sorietr.

Li I)r. Lnnew had not joined the society, although he was cognizant of its existence, Mrs. Annew did not feel that it was his wish to have his brain added to this collection; and as she felt, 
personally, a great repugnance to such an idea, she did not consent to their request.

On March 24 th a plaster-cast was talien of I)r. Agnew's head, face, and hands by Mr. Thomas Eikens, the artist, and Mr. Samuel M. Murray, the sculptor. On the evening of March 23d the Philadelphia County Medical Society held a large meeting, at which appropriate resolutions in regard to his death were passed. The following evening the College of Physicians called a meeting for a similar purpose.

On Friday, March 25th, Dr. Agnew was buried. At halfpast 1 P.x. private services were held at his residence, 1601 Walunt Street, by the Rer. W. Hamilton Miller, I).I)., pastor of the Bryn Mawr Presbyterian Church, which I)r. Agnow attended in the summer months. The funcral cortege then moved out Walnut Street to Twenty-first Street, where the funeral services were to be conducted in the Second Presbyterian Church. Eight members of the Agnew Surgical Socioty bore the body to the hearse. Probably never has there becm a more impressive and solemn procession on Wilnut Sitreet tham this one. As the long, stately line moved along in the bright sunshine of a glorious spring day, it semed as thougl Nature were rejoicing to receive into loc embiace all that was nortal of him.

"Not since the burial of Lincoln has there been in this city such a demonstration of distinguished homage as was manifest at the funeral of I)r. Invid Ilayes Ienew. The enreat church was crowded to its onter doors with a pationt congregation, glad even to be near a scrvice in which they could not all participate by reason of their multitusle. Ifundreds tried in vain to join those who filled all the arailable space within, and many lingered near at hand on the sidewalk to the close of the services. Of those who filled the body of the churels. representing all classes of socicty. the majority were men of all the learned professions beside those of medicine and surerery. In weight of character, in wealth of learning, in dignity of 
exalted position, a nobler or more notable array of the living never joined in such a tribute to the honored dead."

No mere professionil and scientific eminence would have drawn out such a tribute. Behind the physician, behind the man of takent, learning, and skill there was a personal character which gave ath these a value higher than their own. His professional fidelity and success were such as to command the respect and admiration of his associates and the lore and confidence of the subjects of his skill. He lad the incommunicable gracionness of one who humbly recognized and leaned on a higher than human power in all he learned and achieved. He wielded to the full an influence which mere ability and skill will never possess. By professional brethren and pupils, no less thin by unlearned and trustful patients innumerable, he was consulted, cherished, revered in a way possible only toward one who is at once a Christian and a phrsician.

Such a man deserves to be set before the community, and especially before the rising generation of medical students and prartitioners, as an ideal and an inspiration. Unhappily, there is often a dirore between the dual ministrations of soul and body, althongh God has wedded them in a mion sacred and lanting as life. Jesus Christ was himself a plipsician alike to the physical and prechical discases of men. He was the divine lecaler alike of the sick and the sinful. And while, in the conomy of grace, there is properly a difference of function between the medical dortor and the Gospel minister, they represut the two silles of one and the same work. The physician who is wise enough not to ignore the pharmacy of grace, and the minister who is wise enough not to ignore the potency of uncedicine. in so fir filtills the ideal of his rocation. Occasionally the two alre combined in one. as in the case of St. Luke, "the belored physician." They are divinely futfilled in one glorious ideal in the permon of "the son of Man."

The large congregation mouming the death of Dr. Agnew were but the imner group of a rast multitude scattered every- 
where throughout the land, who, in their indebtedness to the great physician for themselves or their lored ones, mourn that they shall see his face no more. And whether they conscionsly recognize the secret of it or not, there can be no question that they largely owe their debt of gratitude to the personal virtue going out of him as a Christian physician. Others of the great throng, sincerely mourning his loss, will cherish him as an illustrious instance of one who combined the most eminent scientific ability and culture with unfaltering hath in rerealed religion and in Jesus Christ as the Divine Ifealer of all the ills of man.

Clustering in chairs on the centre of the platform were the Rev. Moses D. Hoge, of Richmond, Virginia. a life-long friend of the dead master; the Rev. J. Addison Henry, D.D., Moderator of the Presbytery of Philadelphia ; the Rer. C. A. Dickey, D.I., representing the Presbyterian IIospital; the Rev. George Dana Boardman, D.D., as Chaplain of the University of Pemsylrania ; and Dr. John S. MacIntosh, Dr. Lgnew's pator.

When Dr. MacIntosh entered the pulpit, he uttered a brief prayer, and then announced the hymn begimning,

"Come unto me when shadows darkly gather";

When the sad heart is weary and distressed,"

and added that all the hymns to be sung during the service were very dear to Dr. Agnew.

Praver was then offered by the Rer. J. Addirom IIenry, in which he feclingly spoke of the death of the eminent surgeon, saying: "We thank There for this beantiful lific taken from us,so faithful, so true, so loving, so wise. IIc calred for us in om" sickness; watehed most temlerty over our loved ones who hane passed away. So true to the interests conficled to him. we rejoice that he was so faithenl to There. Ifrelowed the Mianter and served Him most faithfully all the dars of his life, and he loved the Church of the living God. 'Thon hast taken him to 'Thyself; to the society of those who loved and frared l'lhee when on earth." 
The Old Testament Scripture lesson was read by the Rev. George Dana Boardman, and, by request, he selected the 39th and 23d Psalms, the former begiming: "I said I will take heed unto my ways."

Then in sweet, low tones was sung the familiar hymn, "Nearer my God, to Thee." This was followed by the reading of the Epistle of the Resurrection by the Rer. C. A. Dickey, who, by special request, selected the Scripture commencing: "If the daid rise not, then is not Christ risen."

Following the Scripture lesson, Dr. MacIntosh delivered an address, fommled on the 31 st verse of the 16th chapter of Proverbs: "The hoary head is a crown of glory when found in the way of righteousness." He said :-

- Crowned with glory is his hoary head! Yes, that hoary head we all knew so well and loved so deeply through these many years is crowned to-day; crowned with the mournful respect of this sore-stricken community and this saddencel land; crowned with the tearful love of comntless bereaved friends, many of them the best and foremost of our time; crowned by the sincere affection, love, and high-heaped honors of the noble and cmobling profession wherein he stood foremost and was wrereded at a fither ; crowned by his church and the broad Cluistian brotherhood that huew his earnest, simple piety, his sinererenvidions. and his life-lone manifestation of Christ-like virtues arowned by un all, and light worthily, for this man of srinece and of skill was a man of goodness and of God; and he. if ever another. Was always found in the way of righteousness. So, tis fitting that we should think of him who was to us so helpenl and inspiriug.

"Another firend has gone! Ah! how true he was to all he lored! Anotlere helper passed away from strugghling humanity! Lh! how ready he was with words of cheer and works of merey! Another master foremost in wisdom silent forever! Als! how fondly loved for his own unique worth and his stored wistom that we may use no more! And another 
member gone out of this flock of Christ that needed him so much; but gone from us to the light and peace of the eternal fold, the welcome reward of his Father and his God.

"He was one over whom we may well lift our praises, both for his own sake and still more in honor of Him who, as our friend himself was ever first to say, had made him all he was. For this belored physician ever stood forth the conscions steward of the good gifts of God, humbly owning the Hand that had guided him, lovingly tracing the wisdom so manifest throughout his life, and daily recognizing his supreme obligation to his Eternal Judge.

"He was a gift, a glory, and a benediction.

"He uus a gift! Yes; a right royal gift he was from the Giver of every good and perfect gift. There is the gift of healing. Let us recognize it, and let us own Him ont of whose hands we get it for our health and our comfort! If with clear eye we behold in the Aholiabs and the Bezaleels of the plastic fingers and the witty inventiveness; if we find in the statesmanship and leadership of a Moses and a Joshua; if we greet in the righteousness of a Samuel and the poesy of a David; if we own in the farsighted philosophy of a Pand, or the high-soaring genins of an Isaiah or a John, a gift firom God to man, slall we not als truly, as wisely, and as reverently find a lıarenly gift in a Lulie, who, as 'beloved physician,' comes with healing powers to stricken, suffering humanity, to troubled louseholde, to greato usedinl lives that need to be kept alive and made whole for the communities in which they are strengths and lighth and joys, and so reveals himself to us as a very gift from on hight Right worthily does the Great Apostle class with the "Mrond of wisdom' and the 'Word of knowledge' the · Gift of healing.' and rerogurnes in it the hand of the administrative and cmithing spirit of cod. And such a gift we had in this student of tireless pritience, who started with no special adrantages of position; in this strong soul of thoughtful resolution. who honestly willed that nothing to be learned in lis profession or in the gathering lights of 
adrancing science which might minister unto human help should be for him ynknown; in this keen-eyed investigator, who was as busy, as eager and humgry for the last facts of real knowledge in his riper years as he was in the days of adrenturous youth; in this erer-growing man of power, so quietly won and honestly deserved and sweetly used; in this modest spirit, so firm, so gentle, who by his rare capacity for tireless application, by his life-long. yet intensifying derotion to a beloved and entrancing calling, by his pure and monselfish surrender to the exacting dimands of an enormons practice, and by his embracing all the lare possibilities of his lofty professional chair, has risen, without stimine joalons or cury amid the plaudits of his brethren, and the enlad heart of the community in which he was a member, to be a mater in medicine and our chict in surgery ; in him shall we not own a gift-res, here, and in this hom recognize a gift loanced for a while and now recalled? And in doing so we only talie what I can here, as his pastor and his closest friend, all solemuly affim to have been his own riew of himself and his work. For, he owned himself a steward of the good gifts of God; acknowledged himself the servant of all, bound to go about continually doing what good he might, and openly confesed and worshipped and lifted up before him as his model that one Divine Master, the Great Physician, who Himself went about rontinually doing good.

- Will do I remember how, on one occasion, as I was speaking of the relation of Jesus (hrist to the medical profession, and calling Ifim the idcal for all to whom the work of healing was rommitted as a life-task, the strong face of my friend flushed and his eyes luightenced and the lofty form grew more ereet! And the next morning lorought me, as was not musual, the loving mote ol thankfinness that told me how the man's heart hand answered to the preacheres words. So wonder the community to-dialy feeds poor and we stand bereaved.

"Ire wes "glory! Agnew, of Plitudelphiat! 'That was his name. The name and the man were an honor and an ornament to our city and to our University. 
" Well do I recall the days abroad, when in Edinbureh and Glasgrow, and in Belfast and I)ublin, in Paris, in Berlin and Viemna, my Philadelphia heart has bounded within me and swelled with generous pride as the great sureons of those great schools would name him with praise, and tell of his achicrements and repeat some of his words of wisdom. To-diy however, is not the season, for long time must not be talien, to speak at length of what a glory, and dignity, and attraction, and inspiration he was to those ardent youths. to those thronged and eager classes that, year after year, crowded the old room. ever so dear to himself, back of St. Stephen's. and to those who, in later days, from packed University benehes, watched the marvelously swift sweep of those mique hands right and left.—carch firm, both sure and quick,-and listened almost breathlesty to the mrivaled cleamess and briefness, but comprehensiveness, of his own luminous discourse, and gave him not infrequently the outbursting cheer that male cren the old man once more a boy, and bound 'the boys', as he loved to all them. closel to himself and made them love him as a fither; and not a few of them weep over him, as I myself have secn, with a gried that unfitted some of them-not the wakest of men-for inmerliate duty. and made them seek their offices for thought, if not for prarer.

Himself and his University are indisohnhly wodeled. She. the great and growing Triversity, gave to him the splendicl arena where, before the New World and some repurencutatives of the Old, he proved his arknowledered greatuess ats an operative surgeon; she placerl him. year after your. in those fresh circles of young, eager life, which, in his rlinire, freshened and

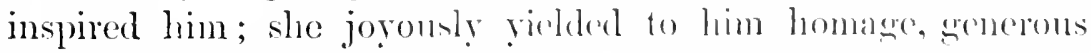
praise, and laresest encouragenent; she opened to him a clear

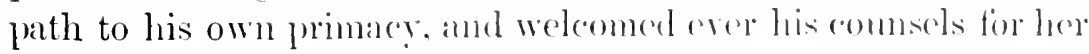
wise changes and contimmens anlargement. And he, on his side, lent to her much of his own alm and clevated dignity, graced her with a laree meature of his own honor, smmmoned hundreds to her halls year by year, made her light more brilliant, 
and threw about her much of his own rich and pure renown. The city and college were proud to call him 'ours,' and each was better, stronger, nobler, and more widely known because he was one of ourselves and in our midst, - a glory and a safeguald!' Yes; he was a glory.

"And he ras a benediction. There are men who, by their very presence, confer a benefit upon all who know them. He was of sucll a very foremost chief. There are men who can see moral greatness; there are men who can picture greatness; but there are men themselves so great they think not of it, yet ever stamp on all they meet some of their own overflowing greatness, and make moral strength beautiful to all who touch them. Of such, he wals one. There are men who are bettered by a noble profesion; there are a few men who better even the two noblest calling on this side of the grave, and among the latter he whom we have lost stood very high-raised indeed.

"Xuw, such a surgeon and physician as was Dr. Agnew,joining a whole-souled self-surrender to his profession with a wholly unselfish fulfillment of its exacting and lofty duties; joining a majestic calmmess of judgment with piercing and instantanenus insiglit; joining the sympathetic tenderness of a fatherly luart to the singular coolness of the most perfect self-control; joining the daring comage of a fearless operator to the soberest "antion of superenely-felt responsibility; joining the broad, comprensive wisdom and knowledge of a great physician to the shill and puwer of the manter-sureon, and lifting all this splendid and singular (ombination up into the mity of his own dignified, molent. wentle. and renponsive personality, - such a man is a rare benedirtions. Inencelietion.- yes; one of the rarest, if he stand in hiv crem-wilening circle of influence, ready to pour out the triatures of his shill, to derote the forces of his sonl to all who

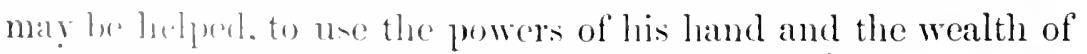
his genim and rharacter upon his younger brethren of his own protexions and upun any sick and womnded ones who, on the Jericlio roal of our common distress, appeal to him for succor 


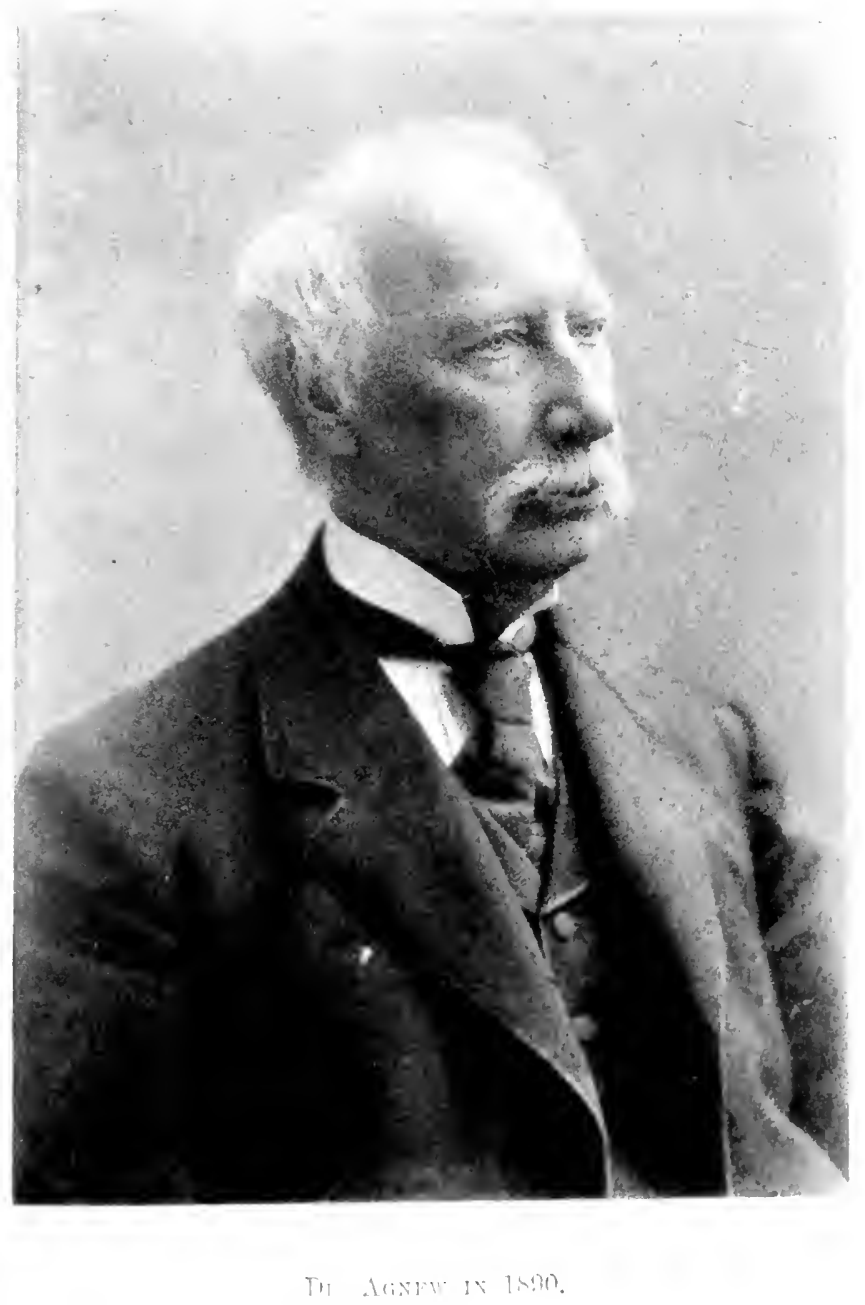


and sympathy. All this, yea, more, do we all know that he was, and for long years proved himself to be.

"Ah, what a gap he leaves! As great as he was good, and better, even, than great! But we yet stand too close to take aright his measure, and so learn our loss. Yes; he was a gift, a glory, and a benediction.

"Brethren of this glorious profession, still so dear to me because of many a precious memory; young men, candidates for fellowship in this goodly guild; Christian men and women gathered in this silent sorrow, what calls to holy living are sounding in our ears! What thrilling inspirations come in this sad hour of parting! What a cloud of witnesses from the spiritworld group themselves in cheering circles round us! Rise to these stirring summonses; answer nobly to these voices; throw your heroic manhood into the good fight; make your womanhood lovelier by sweeter services and more Christly charities. Let us not forget that out of this pew passed the purc-souled Lenox Hodge, and out of that has just gone the princely Agnew ; and mored by their bright examples, and moulded into saintly symmetry by the same spirit's hand, and mastered by the same Lord and IIis love, let us as heavenly (hildren work the will of our Hearenly Father while it is called to-dily."

The Rer. Moses 1). Hoge, 1).1), of Richmond, Va., an old-time friend of the lameuted surecon, who hard been rery dear to him all his long life, closed the services with an address and with a benediction.

"As the vears wear on," he said. "all true ministers of Christ are conscious of an ever-increasing desire to comfort those who need consolation. The Pastor has to bear the sorrows of a great multitude. Erery time a member of lis flock is afflicted his heart is smitten, and there are times when he fects how inefficient all his efforts are to console those who need consolation. But sympathy will not accomplish crerything. What could we do, my dear ministerial brethren, were it not our privilege, when we go to homes made dark and desolate, to say:- 
". 'Come, ye disconsolate, where'er ye languish,

Come to the mercy seat, ferventy lineel;

Here bring your wombled hearts ; here tell your anguish;

Eatrth has no sorrow that IIearen cannot heal.'

" When I look over this vast assemblage, hushed and still, and see the tears not only of bereared relatives, but of a bereared community, I cammot but feel that we all constitute one sorrowing brotherhood and need consolation. Not only in this city, but in how many lomes in this great land, from the Sorth to the south and from the East to the West, are there those who to-day stand before God smitten and afflicted! I know it is true in the home I have left to come and pay this loving tribute to one who was dearer to my heart than any man north of the Potomac.

"But I come here not to speak of the good citizen, nor of the successful teacher, or the eminent author; not even of the man, cudeared as he was to us by his many attractive rirtues.

"I come to spcak of the humble ('hristian, the servant of God, and for His sake the servant of the church he loved so well; and to the Pastor, who to-day mourns a loss which even his words camnot give us an adequate conception of. I come to speak of one who was an honest servant of the Church and of the community whose throes he felt so keenly, and to which he ministered with a tenderness of his own.

- I come to mannify not the man, but the grace of God that most cmobled his life, and that made so tranquil and peaceful lis dath.

- Physical strength may be entwined with the most charming erare of character, but the time will when even that strength will fail. The only staff is the one the preacher alluded to in the 'Twenty-third l'salm, that of the Good Shepherd. 11 onor and power give no joy to the heart that lies still in the coffin, and all the music of the world's applause fails to penetrate the dull, cold ear of death.

- As I look over this andience and see in it such a large 
proportion of young men who have in view one of the noblest callings of life, I am reminded of the propricty of saring a word in regard to the bearing of science and Christianity. I know very well that the heart of our friend was often troubled at the skepticism which prevailed among scientific men. and I stand here on this occasion to bear testimony to the fict that, the more he investigated the ideas and teachings of the scientific studies to which he gave his life, the firmel berame his confidence in religion. In one of the last letters he wrote to me he said: "Christ to me is all, and my aspiration is for the immortality to come.' His testimony is something worth treasuring in your memories.

"His was a complete life. Do you know of anything in which it was incomplete? There are very few complete, symmetrical, well-rounded lires.

"How often it happens that the historian does not live to complete his final volume, or the sculptor his final work of art! Not so with this complete life-an honored life, a peaceful end, and heaven to crown it all.

"And now we are to follow him to the tomb and lay him there, in the sure and blessed hope of a certain resurrection; and in the midst of our grief let us be grateful that the ties of friendship, when sealed by the blood of Jesus, are ties which nothing can finally sever. For these associations shall hare a resurrection beyond the grave. It is but a little time, and we look forward to the season of muion and recognition in the everlasting glory. In the midst of onr gric we can saly: 'Glory to the Father, and to the Son, and to the Holy Ghost, als it was in the begimning, is now, and erer shall be, world without end. Amen.',"

Under Dr. MacIntosh's instructions the great throng which crowded the aisles and the scats slowly passed the casket, and many were there who sobbed as they looked their last upon him they knew well and loved.

Memorial sermons were preached on Dr. Agnew by several 
ministers. Dr. MacIntosh, on Sunday, April 3, 1892, delivered a memorial address, taking as his subject, "The Beloved Physician," his text being Colossians, iv, 14. The Rev. 'Thomas A. Hoyt, 10.1)., pastor of the Chambers Presbyterian Church, preached, on the same day, from the same text. On Sunday, March 27th, Rer. W. C. Rommel, at the Gaston Presbyterian Church, preached a sermon on Dr. Agnew, taking as his subject, "The Blessed Physician." On this same date, Rev. T. 1)e Witt Talmage, of Brooklyn, also delivered a sermon, taking Dr. Agnew and his life as his subject.

'There were innumerable other sermons preached which contained more or less reference to Dr. Agnew and his career. On April 13, 1892, Dr. De Forest Willard read before the Philadelplia Comty Medical Society, by invitation, a paper on Dr. Agnew's life and surgical work.

The newspaper notices on Dr. Agnew's death were tremendous. Out of the eighty thousand periodicals in this comntry, orer nine-tenths contained considerable accounts of his life and work. It was surprising to note the familiarity of each joumal with his name and life-rork.

After I)r. Agnew's death there were a number of suggestions made that a suitable permanent memorial should be made in his name. Certain of his almirers went so far as to offer, through the columns of the Public Ledger, large sums of money if some one would take hold of this movement. A number of letters received from different portions of the comtry also gare voice to the same sentiment. As yet this movemont has not taken shape, but nudoubtedly, if it were pushed prepeny, a snitable memorial could be made for him.

I manoleum has been erected in the beautiful cemetery of Went Ialurel Hill, sacred to I)r. Agnew's memory, and here, ncill the country home he had loved so well, his ashes will rest in peare. 


\section{CHAP'TER XVI,}

Estimate of Dr. Agnew's Position in Surgery.

Dr. AgNew was undonbtedly fortunate in the time of his birth. It occurred just as modern medicine was beginning to grow; during his life-time medicine developed into a great science, and his death did not come until surgery-his principal life-work-stood on a well-nigh perfect foundation.

This century, which has seen so many other professions and industries spring. Minerva-like, into full-grown existence, has been as fully acquainted with wonderful strides in medicine. It is no exaggeration to say that medical study las made a greater advance in the past ninety years than it did in the entire previons history of the world.

There was a culmination of conditions which brought about this wonderful change. The phenomena of disease are so varied and require such a tremendous range of observation over such long periods of time, that no one man, or eren set of men, could arrange them on a scientific basis. It required the simultaneous and continued action, for a long series of years, of a large body of scientific observers, working under the most favorable circumstances, to bring medicine anywhere near the condition of a science. Taking up the application of remedies for the cure of discase, the discovery of the proper drugs was a slow, uncertain, and discomraging work; for, even when applarently powerful remedies were discovered, the proper means to determine the efficiency of these agencies were mknown.

The crude manner in which this inrestigation was carried on, as a brilliant therapeutist has said, was somewhat as follows: When Adam was sick, Ere-for undoubtedly the first physician was a woman-administered to him some preparation made from an herb, plant, or shrub. If Adam recorered from his illness, the data were jotted down in the old lady's memory, 
- for she must have been old by this time, -and when Adam was sick again and presented the same symptoms she gave the same remedy. 'The fact that Adam recorered was sufficient proof to her of the efficacy of her treatment. The suggestion that he might latre recovered from his illness despite her medicine, or that lue drugs had had no effect upon him either way, never entered into her derision of the case. Seeing the disease, giving the remedy, and getting the relief was the natural method of primitive therapeutists. Thus there grew up in every community a system of empiricism or treatment based upon experience, which, as seen to-day, could easily be wholly and radically wrong.

Not only was the work, even when done in a natural and practical mamer, misleading, but there were also a number of fictors which retarded medical progress terribly. One of these was the attitude lodd by the olden masters of medicine, who ronstantly looked for curious solutions to medical truths. For the lumin mind, ever eager to find great governing laws of nature to control the phenomena of disease, was not content with these slow, uncertain processes of discovery. Hence bewan that fruitless search for some hidden law which should gorem the application of drugs in discase. For example, there sprang up in the Middle Ages the doctrine of the "Law of rigniture," which tanght that a drug should be given which resembled in appearance the organ which was supposed to be diverad. For cximple: in liver diseases there should be given aloes, from its fanciod resemblance to this organ. Through coincidence alecs diel do good occasionally, by its purgative action; hener. on such dereptive diata as this, the therapentists of the Middle Lees felt that they had established a great law in medirine. In a similar manuer there arose other absurdities, such as Perkin's 'luartor', the law of "Similia Similibus Curantur," etc.

'Tlue result of these "mions rlelusions was that clear-headed obververs became diesusted with the efforts which they were making for the cure of discase, and so the natural reaction to 
this misleading tendency came at last; it was secn to its fnllest extent in the Viemese school. 'The masters of this areat rentre of medieal education swong to the othere extreme of the pendulum, and became therapentic nihilists, believing that medieines were of no arail whaterer in rliscase.

This unconsciously wave the great opportunity which was to adrance medicine, for under the sway of these teachers the natural history of discase, $m$ influenced by the effects of medicine, was studied for the first time. The pure phenomena of diseased conditions were seen and described at last, as a basis for all future medical study and comparison.

The real condition of affairs in medical circles two centuries ago was seen by many clear-headed obserrers. For example: when Boerhare, the great Leyten physician, died. he left a handsomely embellished rolume, in which he sidel woukd be found all of the real medical litcrature of the world and all of the valuable precepts of medical teaching. When the book was opened it was discovered that it con-isted almost entirely of blank pages. Only one page rontanined any statement; on this it was written, “ Keep your foet wam, your heand cool, and your bowels open." Thiss did the werat Intch physician aptly express the real extent of medical teaching at that period. It is true that a great many facts and a great many disconnected points mating to medieme were ahearly kinown, but they projected here and there. like disconnected mombainpeaks, and there had been thrown hetween them no commecting links of joining knowlelge. 'Ther wore naches to the profession.

Here and there a far-sighted practitioner. living in aldrance of his agre, such as Bonjamin limh or John Ihunter, saw far enough into Nature's truth to prescribe rourses of treatument which, even to-day, must be renalded as quite sciontifice and proper; but at the begimning of the century the ereat choud of superstitious linowledere still humg orer the mass of the medical profession of the world. 
Thus it was that at the begimning of the nineteenth century light was beginning to break on medical fields. Medical men were slowly emerging out of the mists and uncertainties of this strange search for specifies in disease. They were just beginning to learn that the way to acquire Sature's truths is to study Nature's phenomena. It seems a curious thing that it required so many luundreds of years to reach this apparently obvious and natural method of studying disease. Pathology was beginning to be comprehended; obstetrics was being elevated into the dignity of a distinct branch of medical study; gynecology was discovered; while surgery was making a few bold, incisive intrusions into a largely unknown region, and therapentics, the basis of all medical work, was begimning to grow into an accurite science through the medium of experimental study upon animals. In all this adrancing work the American physicians were cagerly pushing to the front, although they were terribly handicapped by the fact that the majority of their number were dependent for their livelihood upon their practice, and hence conld not spare the time for original work or laboratory inrestigations.

It was at this time that Dr. Agnew was born. There was growth in every direction at this period thronghont the civilized worlel. America was rapidly spreading out her domains farther and farther in every direction. The growth of railroads, the introduction of the use of steam, the use of electricity, the extension of the use of the printing-press, and all the varied farcors which make up modern life were just budding into artive existence.

Thre same conditions which caused Dr. Agnew to fail as a business man were to extend a thousand-fold his opportunities as a physician.

The medical jommals of the day were becoming important; their pages were filled with the new successful work which was being poured forth by many encouraged workers. Dr. Agnew grew up with this inspiring condition of affairs surrounding him. 
Following his graduation came the most wonderful discorery, as far as he was concerned, that erer occurred in medicine. It shaped his future career after he felt that he had decided it for himself. This was the practical application of the use of chloroform and ether in surgery. The power of these drugs to produce a condition of unconsciousness had long been known, ${ }^{1}$ but whether they could be safely used had not been determined. This does not detract from the fame of the bold men whose names are associated with their introduction. These operators, unenlightened by any precedent, who pushed the application of these drugs on their patients until they sank into that profound stage of unconsciousness which is necessary for surgical work, were as bold as Columbus when he dared to push his vessel's prow persistently to the westward in search of the Indies.

To us of the present day, who are so familiar with anesthesia and anesthetics, it is scarcely possible to estimate the importance of these discoveries in the ficld of surgical activity. On them is dependent the present condition of surgery. The existence of the pains of consciousness prevented the great majority of the major operations in surgery, while those that were done were performed only through the greatest courage on the part of the operator and patient. 'Time was so valuable, on account of the intense agony of the patient, that only a few hurried euts conld be made in the course of an operation; in consequence, no careful work could be done, no dissecting out of tissues, or removal of any considerable amount of Hesh ; for example, in the removal of the breast for cancer, it had to be cut out in two or three quick strokes. All that was done had to be done almost instantaneonsly. No careful dissection of diseased tissues, or of glands in the neighborlood, which might be infected, was possible. Dr. Agnew was so rivilly impressed with the horror of these operations that, quite frequently, in

1 For example: Dr. J. Jarion Sims relates that in Georgia, long before the introluetion of surgieal anesthesia, the young people engagel in "ether frolirs," in which the use of ether was pushed to a great extent, even occasionally to unconsciousness. 
describing an operation performed before the introduction of anesthesil, his manner and words showed that even the lapse of fifty yours, and familiarity with thonsands of operations in the meantime, had not lessened the lorror of these memories.

The surgeons of that day were obliged to reduce the patients to as near a state of unconsciousucss as conld be safely done; in oriler to accomplish this they were frequently narcotized with linge doses of daudanmm, or they were even bled until conscionsuess was nearly lost. 'Then, limp and weak, the patient was placed on the operating-table, his limbs being strapped down so that in his strugegles he could not move sufficiently to interlere with the acrumacy of the surgenn's linife, while the operator hurriedly made the few cuts which were essential.

In consequence of this state of affiairs, the reputation of the sureneon wh that day was dependent largely on his ability to work with ereat rapulity; while his operations were companatively fow in number. 'The surgeon of that day, of necessity, must have been far more dextrous than one of the present. His work was far harder than at present, and the results he obtained were fur les attisfartory. It las been said that Physick's reputation as a suresen depended largely on his quick and accurate cut throngh the perinem in operating for stone in the bladder.

'The introduction of the use of ether and chloroform into smrerey dhangered all this condition of affairs. The possibility of the production of a state of unconscionsmess, in which a surwenn conld opreate on his patient as painlessly as if it were on an inamimate ol,jeret. made it possihle for the rapid and thorough adrance of sureveal training and ability by giving him complete control of the patient for a companatively long period of time. 'This terrific impetus given to surery ocemred just as Dr. Agnew wats mereing into the wreat stream of the medical profession.

1)r. Ignew saw the great future opening in surgery, and the fact that he determined to take advantage of this opportmity is shown in his attempts to commence dissecting in the country under such unfirorable circumstances as have been 
described. He knew that such work must make him unpopular and his immediate finture most uncertain. The opposition aroused among his country friends and pationts and the consequent loss of practice only urged him to seck such a field where he could continue it at a still greater alvintage and to a fuller extent. This ability to grasp and liecp ny with the current progress of medicine in every department was erer a most marked characteristic of Dr. Agnew's disposition. He used, to the last, the latest instruments and the newest drugs.

It has often been remarked, as a matter of smrprise, that in a prescription of I)r. Agnew would often be seen a drug or preparation which had been before the profession for a comparatively short time, and which many men hall his age had not yet learned to use. In no point was there a sureater sign exhibited of this tendeney on his part than in his relation to the introduction of antiseptic surery. Dr. Asnew. at the time of its introduction to the profession, was. nundonbtedly. in a position as a medical anthority eitler to aid or to retard it comsiderally. The weight of his ereat experience and taining would have had areat fores not only with his stmelents, but with the medical

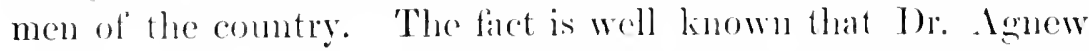
was one of the first to adopt thoromehly and finly all the preecpts and practices of antiseptic surerery. Ilo salw at onee the great alvantages to be derived from its applieation, and le wa its most enthusiastic adrocate.

The advantages of the training of such a selhool as the School of Anatomy to a surerem have been stated drewhere.

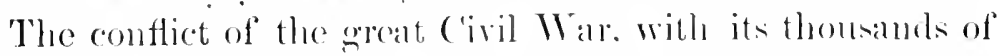
wounds and injuries, with its immmerahle discatses ransed by the life nocessarily led by soldiers, was another great oppontunity to 1)r. Ignew. It ame also. fortumately at a time of life when he was fully prepared to meet its tremendons exactions, and when his reputation was sufficient to enable lim to grasp readily the positions necessary to cxoreise his skill. It the begimning of the War he stood as a clear-headed and carcful 
anatomist and a skillful surgeon. His appointment at the Mower IIospital, Chestnut Hill, where he saw constantly thousands of gumshot wounds daily, and where their course and treatment were brought thoroughly to his mind, was but a natural selection of the most eminent man for the position. He was, at that time, only about forty years of age, but already one of the leading surgeons of the country.

Again, in other connections, Dr. Agnew was fortunate in the time of his birth. In his early days there was no such strict division between medicine and surgery as exists to-day. In consequence, Dr. Agnew's medical training was fully as thorough and complete as his surgical, and he was valued until his deatlı as a most skillful and competent consultant, in many conditions purely medical in their nature. At the same time, somewhat later in his career, there was yet no division of the specialties among surgeons, and Dr. Agnew was at one time a distinguished grnecologist, ophthalmologist, a genito-urinary specialist, and a syphilographer, as well as a leading authority on gunshot wounds, on orthopedies, -in fact, on everything in surgery. Undoubtedly, the ficld of general medicine and general surgery has grown too broad for such specialists on everything to exist again. Those who are pursuing specialties are going so deeply into their subjects, and are becoming so musnally expert at their work, that, doubtless, no one man can hope to compete with them in their special lines of work. This was one of the corollary results that followed the admission of Dr. Agnew into medicine.

IIis pre-eminent position in surgery was shown to the American world when le was selected as President Garfield's chief consultant. The rhance for such a demonstration, fortunately, nerer ocemred before in the history of American surgery. Of conse, his fortunate time of birth and his fortumate career camnot be ascribed in any way to luck. He reached his goal through the most distressing and discomaging of circumstances. The first fifteen years of his professional life seemed 
to him to have been spent in a fruitless and msatisfactory search for a proper field. The fact that such great opportunities existed should not blind our eyes to the equally important fact that Dr. Agnew was great enough to seize his opportunities. To show how rare a combination this was, it is only necessary to note how few of his colleagnes accomplished similar results.

As a man and as a physician he was thoroughly honored. His calm, grave face, so ready to light into a smile, and never wanting its kindly aspect, will ever remain in the hearts of his admirers. He was never morose, never discouraged; always calm exteriorly, yet, after forty years of continuous teaching, he was agitated by an approaching lecture. He was very reticent and undemonstrative, yet always cheerful-a cheerfulness born of his love of God, his profession, and his fellow-men. It was pain for him to be unable to do a friendly act.

Dr. Agnew was thoroughly honest in thought, in speech, and in action. He was honest as a surgeon; he always did the thing which he believed to be the best for his patient. He had no jealousies. His hand was erer ready to assist the weak and struggling practitioner, and the profession of Philadelphia was, through him, raised to a higher plane. His success in life was achieved not by any sudden tum of fortune, but by patient industry, by tireless application. by wise judgment, by thorough knowledge, by consummate skill. and by honest purpose of word and act. He was never ostentations in anything.

One point in Dr. Agnew's dharacter which strikes most forcibly is the fact that he had but few qualities considered in this day to be necessiry to sucess. Young men are admonished that the way to be successful is to be grasping, selfish, and pushing, and insensibly they grow mp with the idea of each man for himsolf; but here was a man who achieved success in life by a diametrically opposite course. II wals modest, retiring, kind, gentle, and deroid of all ambition. Truth was the object of his search; he endeavored to ascertain 
the facts and draw the right inferences; justice was the bedrock of his character.

There was a singular purity about his very presence; God wave him natural gifts of a high order, and he had a perfect hody. Ile owed his success largely to a singular balance of mental and moral qualifications. Novelties never too much tempted nor too much repelled him. He was intellectually very honest. The surgeon is sometimes apt to become dramatic, to love display of his own skill. Dr. Agnew had none of this. Ile onee said that " the immense amount of unpaid service to physicims and their families was hard on bus people; but then," he adled. $\cdot$ it is, alter all, a wreat help to one's self. We ought to be thankinl that we are not always making mere money."

Many men change radically as life goes on; but Agnew war. fiom first to last. yomng or old, the same man. A certain simplicity was in all his ways: the outcome of action from belief was foarless and unquetioning.

In our American world. given to laste, to pressure, and to longing for speedy results and quick retums, he stood a crowning example of those patient and persevering powers which mored steadily to an appointed end withont haste and withont rest. In a sell-secking. arasping age he never swerved from the high stancland of a self-sacrificing profession. In days given to self-aldrertivement he pationtly waited, without selfawertiem. mutil time anme as the fit frout of the mion of genius aml rharacter. Vearswere neded to make his worth known and to romel ont the full measure of public and professional recognition. lut it came. in later years, in an overflowing flood.

I)r. Isnew always intimated the idea that his profession was ". a whine." that the healing of his fellow-men was not only the practier of medicine, but a sacred duty. He folt himself, in a sense, a tmotere of his vast knowledge and wonderful skill. Ile did not reand them as commodities commanding, by reason of their rarity. the highent malliet-purice. He did not, in short, make his fees parallel with the inflection of his reputation. 
Undoubtedly, if he conld have afforded it, he would have done his work without remuneration.

He was possessed of great natural ability and strong common sense; these traits would have giren him cminence in whaterer vocation he might have followed; hatd he continued in business he would ultimately have become a great and farseeing financier; had he tumed to legal pursuits he wonld have been a judge on the bench, learned in the law ; or, drifting in a political life, a senator; had he been a theologian he wonld have been a moderator of assembly, or, in other church relations, would have graced an Episcopal Chair.

In no profession or vocation in life are there more varied. or different, or stronger attributes required than go to make up the elements necessary for the production of a successul practising physician. Many professions or vocations overtalp. in their requisites, the essentials in medicine; but none require more. In the first place, a phyician requires a great matumal condowment of intelligence. Without it, under the reneer of pleasint or polished mamers, a certain degree of sucess can be attinined, but no commanding height can be reached.

Again, a great degree of mannal dexterity is needed. especially in the surgeon. A great surgeon must be a great mechanic. He must be as adept in the une of his hands and in the various laws of mechapies as a carpenter, a sculptor, or a mechanical engineer. Again. he must powess the most imperturbable manner,-must not be upere or disturbed by anything. He is experted to be cool, collerted. and aretive in the most startling or sudden energencies. II te must posens more or less of

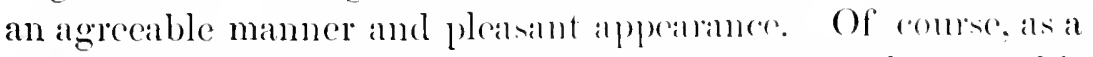
physician grows older and his real worth is better linown. this is not so essential; but in the young physician this is alwolutely demanded. He must possess concentration. Ho must be alble to reach conchusions definitely and quickly. from the alrions data which are presented to his mind. Ile must procesel to formulate his diagnosis like an arthmetician working out a problem. He 
must be willing to work at all times, day and night ; to expose himself to all sorts of dimgers and hardships,-in short, to live a life in which the precepts which he teaches are almost entirely disregarded. IIe must expect to do a large proportion of his work without hope of remuneration,-in fact, he can never look forward to any extraordinary degree of income.

As he becomes more in demand he will be able, only to a slight extent, to use assistants or substitutes. It is himself and his own opinion that are wanted; and he is unable, as in other rocations, to employ a corpes of workers to aid him in his daily work. Of course, to a certain extent, this can be clone, but not at all ats it is done in many other professions.

On the other hand, the advantages of such a position as that held by Dr. Agnew were equally great. Ife was beloved by every one; lis words, decds, and thoughts were quoted and copied everywere as almost infallible. To the American world, who dearly loves a hero, he stood the idcal of the prowess of the American surgeon. The name of Agnew has always been associated with the description of the great Iarrey, the French surgeon, by Nalyoleon: "He was the best man I ever linew."

The extraordinary reputation, honor, and romantic position of Dr. Agnew in the world of medicine was not without its effect upon his profession. Ite placed the ideals of the profesion upon the highest levels, where they will permanently remain. For his life-work, the accomplishment of this object was enongh in itrli alone. 'The American public have been taught by his example what a physician can be.

Ilis fanc, attracting the eye of young America, has created a great furope for surerere. The aspiring collegian looking for a profession is fiequently influenced to talie up medicine, and particularly surery as a lifi-work, simply from his impressions of I)r. Agnew. Lndoubtedly. Dr. Agnew's reputation has caused the surcical world to be filled to overflowing by aspiring applicants. It has given an impetus to American surgery which will redound forever to the credit of the New World. 


\section{APPENDIX.}

\section{Credits for Material Used in the Agnew Biography.}

In preparing this biography it was the olject of the writer in all cases to go to the original sources for obtaining data. In all calses where it has been possible this las been done. In obtaining this material it las been verified or disproved by parallel comparison as fully as possible. This was possible to do, as nearly every bit of information has heen reeeived from two or more wholly different sonrees.

Of course, the greater part of the material comes directly from Dr. Agnew himself, or from material furnished by Mrs. Agnew. In all cases of dispute Mrs. Agnew lats been the jumge. and to her judgment has been sulmitted every point of dispute. 'Thanks are dne to Mrs. Annew for this service which she has rembered, especially as, being in poor health, she has fuldilled the painful duty of examining and verifying the story of her husband's life, in orrler to get it into proper shape for this biography. Without her assistance much of the record would be totally watiting.

Dr. Annew's lectures, prirate notes, books, and letters have been carefully gone over in orler that nothing might be misicel which conld be with propriety inchured.

Credit is dne to the following books from which information was obtained :-

The Homes of Family Names, hy H. B. Guplyy.

'The Origin and Signifintion of seottish Surnames, by Clithor Stanley Sims.

The Genealogieal and Irualdic Genealogy of the Peerage and Baronetage, by Sil Bernard Burlie.

Debrett's Peerage, Barometage. Kuightage, and Companionage, 1892 , 179 th year of pullication.

Men of Mark of Cumberland Valley, Penusylvania, 1776-1876, by Alfied Nevin, I).D., LL.D.

Strong Bow's Conquest of Ireland, edited by Francis P. Bamard, M.A., London, 1888.

English History from Contemporny Writers.

Colgrave's History of the Norman Compliest.

Cliambers' Lives of Eminent Seotehment.

Dictionary of National Biograplyy, MacMillan \& Co. 
Biographical Enerclopedia of Pemnsylvania of the Nineteenth Century.

Jereclitary Sheritfs of Galloway, by Sir Andrew Agnew. For a copy of this extremely rare and interesting book, thanks are due to the son of the anthor. the present Sir Antrew Noel Agnew. The book has heen given to the Historical soeiety of Penusylrania, where it may he consulted ly those desiring to stuly the history of the Agnew fomily more in retail.

T'he Bioglaphical Outline of the American Agnew Family, compiled by smith Agmew (unpublished). For the opportunity to study these sets of remalkibly complete genealogical tables, thanks are due to his gramkiom, Mr. smith Agnew, of l'ittshurgh.

Cartons llintory of the Medical Department of the University of Penm-ylramial.

Catalognes of the University of Pennsylrania, 1830-1892.

Philadelphia Itospital Report, vol. i.

Iieports of Philatelphia Hospital to Board of Guardians, 1856-1870.

Ilistory of Chester County, hy J. Smith Futhey.

IIi-tory of Laneaster Comnty, by Franklin Ellis and Samnel Evans. Ilistory of Philadelphia, by Scharf and Westeott.

Itistory of Delaware, by scharf.

Hintury of Jullerson College.

Giross" Amtohiography.

sim stom of My Life.

In whition to these works, thanks are due to Mra. Mary A. Wallace,

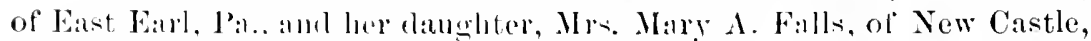
Pa., Dr. Agnew's half-sister, and her danghter, and to Mrs. Mary Irwin Agnew, niece of Dr. Agnew, and Miss Martha A. Agnew Stuart.

In the rleceription of the sturlent life at the University from 1835 to 1860. thatuk alde due to Dr. Alfred Stille, of Plailadelphia, ant Dr. Traill

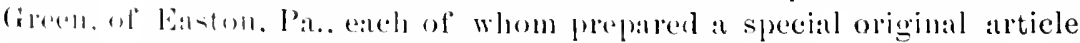
ont this sul,jecet for this hiograplyy.

Thankis are also due to Dr. James L. Tyson, of Penllyn, Pa., who prepareed the deseription of Dr. Agnew as a student at this periot. Dr. II. $\therefore$. W. Runchemberwe also supplied sume interesting reminiscences

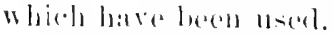

('berlit is due to Lron Making and Coal Mining in Penusylrania, ly James . W. swank, for rerification of muclu of the material collected from fimily stories and from a survey of the business world of this perierl.

'The IIintory of the Philatelphia School of Anatomy, a lecture delivered hy D. W. W. Keen, Mareh 1, 1875, at the closing of the school, 
forms the basis from which has been prepared the history of the eonnection of the different teachers of this school, with the exception of I)r. Agnew, down to 1875 . 'The story of Dr. Agnew's eonnection with this school has been prepared from many different sources: anong them, from a paper prepared on this subject by 1)r. James E. Gatretson, and from information furnished by two of Dr. Aguew's former demonstrators of anatomy, Dr. Robert Bolling, and Dr. John W. Lodege. 'The history of the selool since 1875 is compiled from the owners of the school at the periods mentionel.

The account of Dr. Agnew's connection with the Philatelphia Ilos. pital was prepared from his own clata, am from the original reeords of the hospital, through courtesy of Dr. Charles K. Mills.

The oflicial report of Dr. Agnew's services during the Civil War was furnished from the records in the Surqeon-General's oflice in Washington, throngh the courteș of Dr. Joln S. Billings, U. S. A., and Deputy Surgeon-General Charles R. Greenleaf. Drs. Lodge and Morton also finmished data in this comnection.

Dr. Agnew's connection with the University of Pennsylrania was prepared from the minutes of the meetings of the 'Thustees of the Lniressity of Pemsylymia, thromgh the combes of the Rev. Jesse Y. Burke, and from the minutes of the mertings of the Faculty of the Medieal Department, furnished throngh the comtery of the gentlemen composing this distingnisher body. To Mr. William II. Sal vathor thatuks are alwo due for the use of his inexhanstible supply of information on this suljeet.

The areomt of Dr. Agnew's connection with the Wills Eye IIospital was prepared from data furnislsed by I)r. Chandes $A$. Oliver.

Dr. Agnew's connection with the P'musplvania Hospital was witten from material furnished hy Mr. Benjamin II. Shoemaker, President of the Board of Managers of that institution.

The acconnt of Dr. Aenew's connection with the Orthopedic IIospital was prepared from data fumished ly Dr. Frank S. Pearee.

The estimate of Int. Agnew's services in the Faculty of Medicine was written hy Dr. Willitum Peprer.

The article by Dr. De Forest Willand on the life of Dr. Agnew hats been freely quoted, as has also a similar one by Dr. Johm Ashlumrst, Jr., puslished in the International Clinims for July, 1892.

The material used in the Garfield ease was prepared from the original notes of the case as written by the attenling plyysicians. 'T', Dr. Robert Reyburn thanks ald due for the privilege of examining these documents. Dr. Bliss' article in the New York Hedical liecord and the editorial comments in the same jourmal have also been used when essential. 
The acconnt of the jubilee of Dr. Agnew was taken from the original manuseript in the hands of the speakers and writers.

For various ficts and dati, thinks are due to Drs. Wharton Sinkler, Frederick P. Henry, Wm. M. Capl', James Tyson, J. M. Da Costa, Francis E. White, Lewis A. Sayre, Wm. Goodell, H. C. Wood, Johm Marshatl, R. A. Cleeman, S. Weir Mitchell, Thomas S. Neilson, J. Ewing Mears: also to Messr's. Coleman Sellers, Craw ford Aruold, J. Simpson A frica, Hon. Andrew G. Curtin, Gregory B. Keen, Col. A. J. Rockwell, Ilenry Chapman, A. J. Cassatt, Mrs. James A. Garfield, Jos. H. Swain, Rer. E. R. Craven; Frederick D. Stone, Librarian of the Historical Sucietr; Manzo Kushida. 


\section{INDEX.}

Abolishment of hereditable jurisdictions, 16 Agnew family, coat of arms of, 19

Abohition of slavery, speech on, 129

Abolitionists, $12 \mathrm{~s}$

Abrahan buncoln, 129

Acadeny of Surgery 271

annual oration before, 271

Accident, run-iway, 73 while fox-hunume, 57

Adams, J. H1 , :315 Margavet Agnew, 250

Address, at band lint to Dr. Gross, 298 at funeral of 1)r. Antew, 34t-351 by Dr. Annew on retirement trom Univerity, 331 valedictory, $110-126$

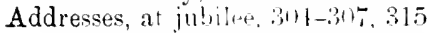
by Dr. J. M. Dit Cinta, 302 by Ir. Hewls 1 sayre, $30 \mathrm{~s}$

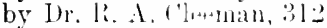
by Prot. samulu II. Ciross, 315

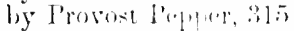
l,y Wilh:am li. L,mmaln, 315

before Amersan Surgeal Ascocration, $197-2] 9.20 \%$

Agneaux, a villate in X rethern France, 1, 2 derived from the Latm tem agnus, 1 fanily namt: derreel from, 1

Norman Frombl for "lamb," 1

Agneaux, d', Jean Jacines Fiene de Ste. Marle, 1

Marqus de ste. Marie, 2

Sir liulke, +1

Sir John, 4

Sir Philip, 4

Sir Welliam, 1

Ste. Marie, 4

Agneaux, heralclic achievernents of the, 3

Robert and Autoine, t

Agneaux de l'lsle, 3,6

descentants of 1

Agnew, a town un Nebraska, 1

Andrew, 10

Benjamin S., $: 3$

Cornelius R, $3 t$

Daniel, 3.1, 135

David, 2t, $1: 3$

descendants of, $2 f$

David llayes, 21, 25, 39

Dr. D. IIaves, vear of birth, 19 year of ileathi, 19

Erwin, 33

family, American branch of, 23 baronetage of, 17 earliest recoril of 1

great lowght and splendid physique of. ‥?

knightloon of, 17

lineacen of 1

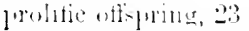

prommence 11 religions matters, 23

frombent an early history of Americal, 21

rovil inesent of 11

scinth bram ha of is

Gencral James, 11, 204, 30

James, 2t, 是

dememlants of :-1

John 1lulnes, 识, 41, 126, 135

John l', +tis

Patricki, 11

Prot. John Holmes, 135

Lire. latiol C. A., :3

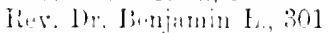

liev. duln lloher. 11, 12ti

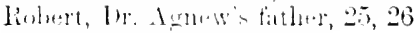

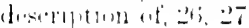

S:IIIII) $: \geq 1$

Sur Anlew 10, 11, 14, 1013

Sir Ambew Nool, la

Sir l'atriek and denerntants, 18

Sunth, 2:;

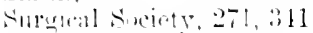

its bannuets $2-20$

vitume watys of "splling, 1

Agnow, a brillumt contretsitionalist, 253

a "borm lector," "iti, :

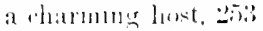

a consistent chostian, 2til

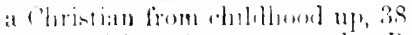

a consulting surgesen to the f'resbytortan Ifosital, 证)

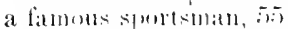

a Fellow of the Aneruan Surgical $A$ ssinciatsing,

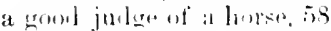

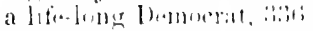

a member of Buard uf birertors of tho lomon Trust cimpany, 271

a member of the . Lmemin lhilosoph-

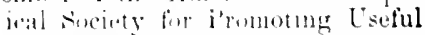
kinowherlen

a meminler of the. Franklin Institute, 27

a memler in the Bund of Nanagers of

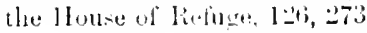

$(369)$ 
Agnew, a member of the Phladelphia/Agnew, elected Attending Surgeon at Penn-

County Medical society, 126

a member of the American Colonization soclets, 120

a menter of the Melical Examining Board for Volunteer Surgeons. 131

a mmber of the Merlual society of the State of l'enusylyania, 268

a menter of the A II II $\Omega, 273$

a nember of the Faculty of Medicine in the Cniversity of Penneylyania, $139,152,156$

a society named after, 271

a strict Calyn Presbyteran, 258

a student at Jetlerson College, Cannonsburgh, Pa., 10

a student at Newark College, Del., 41 recorl of his experience there, 41

a stulent at the Cniversity of Pennsylrania. 42

a tireless worker, 2in

a Trustee of the Phuladel lun Dental College, 275

alstemions with fool and drink, 252 agan locates in l'hilateluhla, 73 anbinlextrons, 14:9

an ilual teacher of surgery, 157

an example of punctuahty, 169

an early riser, 2:51

appointen surgeon of Tolunteers, 131

ayprowe of fure humor, 253

as a lecturer, $-19,139,155,166,3 \mathrm{I} 8$

as a fublisher, $193-196$

as a sureon, 161

as a sylinlograjher, lon

as a writer, $113-116,193-219$

as Arting Asstant surgeon in the ['nited statw Army, 1:31

as an expert in medico-legal cases, 245

as an reprator. 16 t;

as consultug surgenn, 131, 152, 165

at MI, whe cimerat Hospital, 131

as Curator, 113

as bummeman of Anatomy in the [onversts. 135

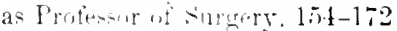

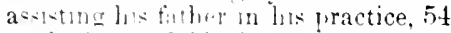

at the hattit-tinll of diettroburg, 133

attracten to eltrerymen, 258

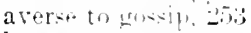

bantplet to. : : (x)

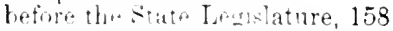

clanges his r+sulfothes, 153

comes to lluilately hat iz

death of, 340

decides to lecome a surgenn. 70

description of in $18,54,51,52$

disluked by cuntry lifolle because of his method of stmdying anatomy, 71 duck-shooting, 57,55 sylvania J Iosfital, 144, 145

Attending Surgeon at Wills' Eye Hospital, 142

Professor of Clinical and Demonstrative Surgery, 139, 141

Emertus Professor of Surgery at University, 276

establines the Pathological Museum, 113

fond of bymns, 263

of medical stmilents, 271

of reading, 252, 254

fox-hunting, 66

funeral of, 341

gives ul' practice, 55

reasons for, 60

gold nedal presented to, 315

had friends every where, 254

Honorary Professor of Clmical Surgery at Lniversity, 276

Honorary Surgeon to the Presbyterian Hospital, 275

in the Garfiell case, 204,249

Orthopedhe Hosnital, 108, 149

Pennsylyania Hosl,ital, 107

Philarlel y,ia Hos Iital, 107

School of Anatomy, 76

Lniversity Hospluta], 108

Wille Eye Hecputal, 108

joins the College of Plis:reians, 126, 267

locates in soudersburg. 73

loved to entertain his friends, 253

made Fmeritus Surgeon to Wills' Eye Hosprital, 14:

meets with a run-away accident and is seriously mjured, 73

not oplosed "in the higher education of women, 148

one of the fommlers of the Atheneum Literary Society, 41

operating at Geneva, 250

plain m lis drese 250

jractising at Cochranville, 70

at Nobleville, 5o

at Pleasant Garlen, 55

President of the American Surgical Assoclition, 2his

of the Medical Society of the State of Pennsylvania, 268

progressive, 359

receires bonorary degrees of A.MI. and LL.D. from Princeton College, 159

returns again to meslicine, 70

seemerl alwars young, $256^{\circ}$

sickness of, $339^{\circ}$

speaks on the abolition of slavery, 129

studying anatomy, 52. 71

Surgeon-in Charge at Hestonville General Hospital, 1:31

" the ductors' doctor," 302 
Agnew, tolerant in religious beliefs, 258

town of Agnew, Nebraska, named in honor of, 1

tribute of respect to, $28 t$

Vice-President of Alumni Society of Medical Department of University of Pennsyliania, 275

well acquanted with theology, 258

well known to the prolession in Earope, $335^{\circ}$

well received in Philadelphia, 106

Agnew's address, at banquet to Dr. Gross, 298

before the American Surgical Association, 268

on cranial and heart wounds, 197-206

on retation of sucsal life to surgical disease, $207-219$

on retirement from the University, 331

addresses at jubilee, $304-307,315$

annull visit (1) parents, 69,70

appointment as Professor of surgery at the Unicersity, 15t

at the Orthoperlic Hospital, 119

attendance on (ieneral Winfield s IIancock, 18:;

on Presilient James A. Garfeld, 221249

Mrs. Ciarfielil's estimate of, 247

belict' nn divine gurdance, 257

birth, 25

birthilace, 28

boyss life in the country, 39

business venture, rio, 75

calun exterior, 3 in

chertuhess and forbearance, 261, 202

classicial erfucation, $3: 4$

class-mates and follow-graluates, in , 51

connection wath hospital ruties, log

with the Phitaldelitic Sohoul of Anatomy, 7t; los

woth thr Pleasint Garden Iron-Works, 150-69

courtshy and marriage, 51, is

degrees, 337

dislike for complunents, 259

towam the mixul clinique, 119

duty to his patients a sacred trust, 2.09

early lile, $33^{3}$

in Philaloluia, 10r-1:27

education at Jefferson College, Cannonsburgh, Pa. fo

European trip, 250

experiemes as a conntry justrian, his

first appointment at the Universy of Pennsytrania, 136

first meeting with has futhre wife, 38

freshness and enthmsiasm, 20,

graluating thesis, 53, , it

destroyed during fire at Lniversity, 53
Agnew's graluation, 50

Hasertord home, 251

home-hife, $2: 31-2015$

mgenuity, 17t

jubilee, zigs

kmelness of heart, 1:22, 205

last ajpearances at a public meeting, 337

last didacte lecture, 321-3:31

later life, $2157-297$

life from 1560 to $14,70,128-1,33$

love for his wife and fanily, 35, 261, 265

love for thes suty of anatomy, j2

magnificent cousitutution, $254 i^{\circ}$

most infurtant posituon in operative work, 113

oljecton to fiemale sturents, 145

observance of the Lorit- Day, 257

orisinal investigations, $17-\overline{-j} 92$

work in surgery, 17\%-19z

prapents, 25,89

descrution of, $29-29$

personal appearance, bis

fortratt (trontesinect), 314

position an surgery wtmate of, 353-364

presents from lis" atmirers, as9

progress, 107

relatives prominnat in history of Pennsylviniat, $2 ! 9-31$

respect for dum man melicine, 251

retirement from the l nuversity of P'ennstrantia, $: 31$ -

return te Xobleville, is

school litys. 37

separation from the Schoul of Anatomy, 105

servimes as a streron, entimate of, 171

sicknes, whath, atm finteral, 339-352

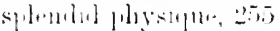

summer trifis, sit

"sturers," liju, 201

ralulutory allineses, $116-126$

writusers 193

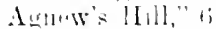

Ann'W, Anteriean, genealngy of, 23

of Jonlonaw, lo, 2.:

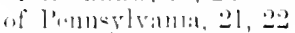

of the simuth, -1

Narice, I:3

Alenceurts, line of the t

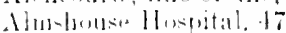

Alummi Sielety of Mndieal Department of

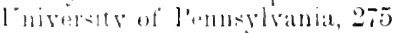

Anbirlexterter, 17i

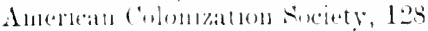

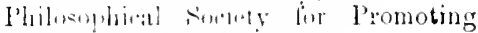
liseful kinwledion, 证

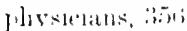

sirmery, Nestor of 209

sumat Asseriatum, addresses before, $197-2420$

Amuing sury of " Blockley," 109 
Anatomical lisections, 53

"Anatmor Acts," (4)

Ambew $\mathrm{I}-\mathrm{m}+\mathrm{W}, 10$

Anectoles $27 i$

if Ir. Anuew's boyhood days, 36-39

Anesthesia, $3 \pi$

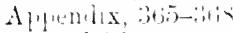

Armorial hearmes. 3,4

"Armorial de bamee," 4

Aptules and lumk publishen by Dr. Agnew. $1: 1,1-1+4 ;$

Atheman Literary fociets, 11

Allee, Ir. Wialter F, 25:

Antorit on J'mulent James A. Garfield, (i)

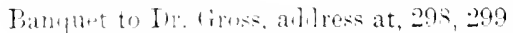

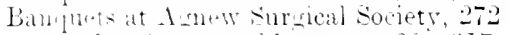
to 11. A-11.W. a blenes at, $300-317$

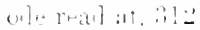

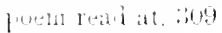
- wereven liy J. H. Adams, 315 $: 11 ;$

mu-i tu, hy IIngls A. Clarke, 316

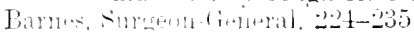

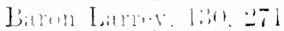

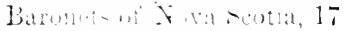

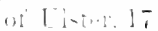

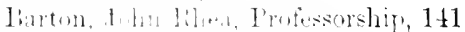

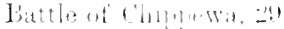

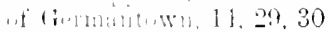

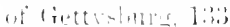

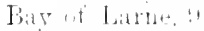

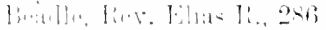

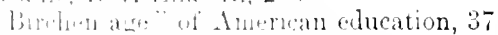

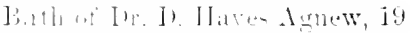

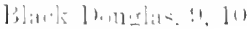

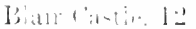

$$
\text { 1]. }
$$

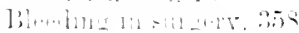

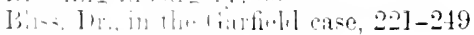

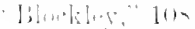
intm-ing tom of jog

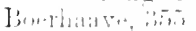

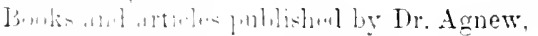
$1+3-1+n ;$

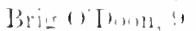

"Thmon hint" "f Sir Anlrew Agnew, 15 lammentestaly of 15

Brum. Iilwarl, 7

Jials. I5

litiditt 7

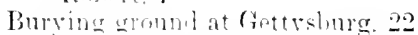

Busimess rentur" lm. Aintew's, 40

Camp-meetmo, ::T

Camp-stors, It

Castle of Lorhnaw A. 7 abturew by one diclellan, 8 retaken by one of the Agnews, 8, 9

Charles I, 17
Charles II, 18, 20, 21

charles $r:$, I

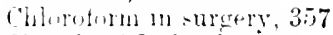

rhureh of I leland, -2i

Cw1 War, ts, 91. 10s, 113, 131, 359

l'leman. Dr. R. A., aldress by, 312

Clinical m-tumctum at the Lniversity, 139$1 \cdot 1.2$

Surgery. Chatr of, 139

Chul, Fridar-Evenme, $26 !$

Xomiay-Eveming, 269

Pend. Pectition to Dr. Agnew, 317

Saturhas Night, 273

sorlal suruseal, 270

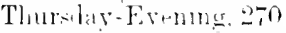

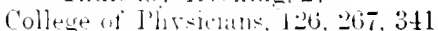

Colonsatwe if the Nonth if Jreland, 20 statetr, Ime+ran, 12s

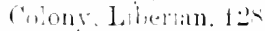

Cimmenement eve at Musical Fund Hall, in)

Comment voms lurtez rous, 15

Cimplater of Eliter. 6

(in-tilile of Luhluaw. T, 9

Consulting sureon. Ir. Agnew as, 131

Coneliu- Li. A guew, "4t

Comer IVienwo. 5,21

Iterehtary shertit of 5

Cranial and lifart wommls, medico-legal as-

Cromment], 1s

lects of, $1917-206$

Curator. 1). Annew as. 113

D'Aeneallx, see Auneaux.

lit (ista, I)r. J. .I., alliess by, 302

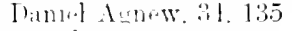

Jarlul A

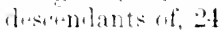

Thril Itares Ampw, 21, 25, 36

Dentle w Ir. 1). Inves Asnew, 340 of llusilent lanes A. Garfield, 232

Dhelaware ('ollectot, 11

Domartment of Mamehe, 2

Inolvitum of fimmly name of Agnew, 1

Inomeras. Biack. 9, 10

larl, s. 9

Sir Willian, 9

Dr. D. Halyes Agnew, rear of birth, 19 rear of leath, 19

Durk-shooting, 57, 58

Dukes of Argyle, 16

Farl Douglas, 8

Earl of Morav, 7 of Strigul, 3

Farliest record of the Agnew family, 1

Earls of Rothes, 10 of Trrmes and Tyrconnel, 19

Early life of Dr. Agnew, 36-59 in Philarlelphia, 106

Edward Bruce, 7 
Eels as assistants in studying anatomy, 7I

Emigration to l'ennsylvania, 20

Erwin Agnew, 33

Ether in surgery, 283, 357 frolies, 357

Exiles from France, 3

Faculty of the University of Pennsylvania, $43,47,137$

Family name of Agnew, derivation of, 1 trailition, 3

Favorite Galloway story, 11

"Fax mentis honestre glorie," 18

Female students, Dr. Agnew's objection to, 145

Ferdinand de Soto, 123

Feulalism, essence of, 6

Fire at the University of Pennsylvania, 53

Firth of Clyde, 7

Fox-hunting, $5 t^{\circ}$

Franeklyn Cottage, $23 \mathrm{I}$

Franklin lustutute, 25: Medual (w) bege, 95

French husalue, kuights of, 3

Friday-Evening Clul, 269

Frolies, ether, ist

Funeral of Dr. D. Hayes Agnew, 341 address at, by Dr. Macintosl, 34 services at, $313-352$

Gallowar, $5,7,8$

Jordsliu, of, 10

Sunts of , is

sluerifit of 5,19

story, farorite, $1 \mathrm{~L}$

Garfielel case, 2:20-219

disension on treaturent in, 236-242

incident on the, fis

physicians in attentaner, 221, 221

Geneabury of the Antrican Annews, 23

General Janes Aenew, 11, 29,30

Wutiellis. Ilanevel, 133

"Cienthenen's Jaw," B

Gettysture, Battle of, 133

"Ginny students," ts

Gold medal presentel to Dr. Agnew, 315

Goldsmith, l1s

Grarluating thesis, Dr. Agnew's, 53, 54

"Green Box," or "Cireen Tirom," 50

Gross, Prof. Sammel VV., alluess by, 3 I5

Guitean, $2 \cdot 20,212$

Gunshot wounds, 132

Hamilton, Dr. Frank II., 221-249

Henderson, James N.. 2.9, 37 Rev. Elbentzer, 25

Heraldic achievements of the Agneaux, 3 bearing of Agneaux de l'lsie, $3,+4$

"Here me is," 38

Hereditable jurisdictions, abolishment of, 16

Hereditary Slieriff of Wigtown, 5, 8
Herenditary Sherifts of Galloway, 18

Hestonvilie lieneral l[osultal, 13]

Hoge, liev. Mowes D., 2is, 343, 349

Hosputal, Almslouse, 17

blocklere, 10s

Ilestonville General, 131

Nower linneral, 131, 133, 360

()rthoperlin, fon, 119

l'tousylyant $16,17,107,143$

Phuardelua, 17, 9(1), 107, 108

Preshyerm, 2-5

catterlet General, 1:31, 133

Univerenty 1 is

Wills Lie, 107, 143

House of Refuge. 124, 28

Huguenots at thme of Lieformation, 3

Hunter, Lr. 'harles 'T', lis Jolin, 355

Hymn, Wesley's latst, 263

Infidele, services atramst, $t$

Instruments derised by D)r. Agnew, 17t-177

lown industry of P'om

lrwm \& Anew, form name, 167 failure of , tit, (is

Irwin tianty is M.umatet Creighton, 35, 5.t

Jamis din+w, 21, 2:? deveenlants of, 21

Janes 1, 1!, $\geq 0$

Janes 11, 20, 21

Jean tacidues Rurno de Ste. Marie d'AgH1:at1x, I

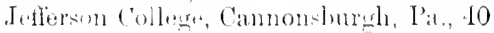

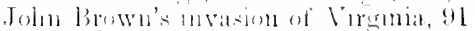

Toln IInlmas Aentw, $: 3,11,126,135$

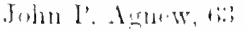

"John lihea Iarton I'rofesorship of Surgerry," 111

Iommals, mialinal, in

Juhilee of Dr. Adruw $258-317$

Julge M. Russell Thayer, 337

K:11m, 121

Kiver, 1.5

King Thavil II, 7, 9

King fanes I, 10,17

Kng oi trelame, 7

Kinir liolure Bruce, 7

Kirkemblingt, is

Kuights of French chivalry, 3

La Manchr, 2

"Lav"(n1,"l2t

Lady liruce, 15

Laird of Lorhuaw, ?

I.amb, I)r. I). \&., 233,235

Lamminmir lion, It

Lancalster County Medical Society, 266

Larne, bily of, $y$ 
Larne, Lord of, 6, 7 longh of 7

Latta, Rev. Franeis, 39, 40

Lamlanum in surgery, 358

Law of Simnatures, sist

Leetures, in. Aunew's, 19, 139, 155, 166, 318 last didactie lecture at the Unversity of Pensylvania, :221-331

Leidy, 1)r, at the' lniversity, 78

Liberian colony, I:y

Lile, Dr. Annew's early, 36

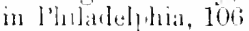
of 1)r. Annew from 1860 to 1870,128

Lincoln, Aliaham, les Dr. N. S...2.1

William R., athlese by, 315

Eine of the Alencourts, 4

Eineatge of tha Agnew family, 1-35

Loclinaw, 6, T [at te of , B, $7,9,10$

Constable of 7,9

hairl of, :)

loch of ?

Lord of Alenesurt, 1 of Jiame, 6, 7 of l'J alo and Anral, 3 the heralla hearing, 3

Iorels of $($ liter, 7

Lomlation of harme,

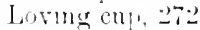

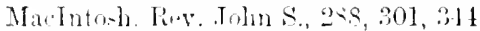
hins remunacences of Dr. Agnew, 288-

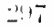

Mate Teand, Wayme, 2.-1

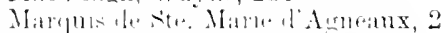

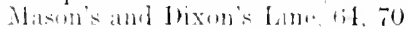

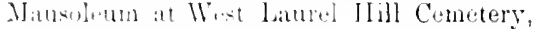
20

Malual instrutum of fifty years ago, 45-50 Institut, $1: 1,9+;, 110$

jemmits, :in

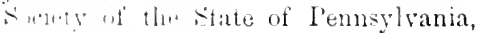
2is

Mermorial aromons :

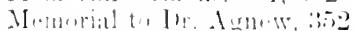

"Memhant of l'onlen" |l!

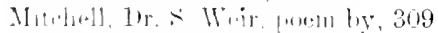

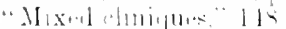

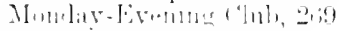

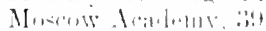

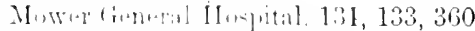

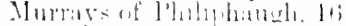

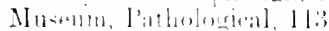

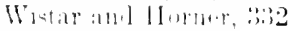

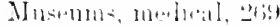

Name, Agn+w, mum rons ways of spelling, 1 derivation of

Namelen, fo, 12:;

Nestor of Anerlean surgery, 269
Newark College, Delaware, 41

Noble family, 26

Norman conjuest of England, 3

Normans, or Norsemen, $\ddot{2}$

Nova scotia, lraronets of, 17

special honors granted to, 17

Ole by Dr. Thomas Wistar, 312

Odertleet Castle, 7

Urigin of name of Agnew, 1 of town of A gnew, Nebraska, 1

Original investigations, 177-192 work in surgery, 173

Orthopectic Hospital, 108, 149

Painting of Dr. Agnew, 332

Iresentation remarlis by Dr. J. A. Scott, 332

reception speed by Dr. S. Weir Mitchell $\quad 334$

reply of Dr. Agnew, 334

Pathologreal Nuseum, 143

Patrick Annew, 11

Y'tmi ('luit receltion to Dr. Agnew, 317

I'enmsylamal emlgration to, 0

I'enmsylvamat Aralerny of Medicine, 101

líosital, 16, $17,10 \overline{1}, 143$

Medical Collecte 110

Pepuer, l'rovent, andress by, 315

l'trlin's tractors, 354

Philitlelpha Anatomseal Rooms, 78, 82, 83

Assoriation for Medical Instruction, 96, 17

County Melical Society, 110, 126, 149, 267.311

Dintal collegre, 275

Hospitil, $47,90,117,108$

Polyelinn ant college for Graduates in Mielicine, 95

Sehrob of Anatomy, $7 t-156$

its hustory, $76-$ tits

receilite from, (12)

Schnol if Oprative Surgery, $8 t$

fees from, ? 2

Univerwity of Mealicine and Surgery, 154

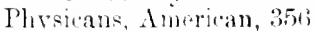

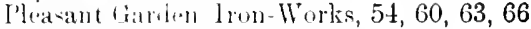
ruins of tis

Portrait of $\mathrm{br}$. Annew (frontisplece), 314 of I) Alfremi stille. 315

Post-morten of bily of I'resident Garfield, $3: 3:-3,5$

Probsterian ] [ospital, 275

Princens Marnaret, 10

Nary 10

Princeton Collexe. 159

"P'rintinles and I'rattice of Surgery," 160 translatel into Japanese, 163

Private classes, 48, 4!

I'rotestant exiles from France, 3

P'roviderice, 116,127 
Quiz classes, 49, 76

clubs, 49

work, 95

Rebellion, War of the, 128

Record of the Agnew family, earliest, 1

Reminiseences of Dr. Agnew, 288-297

Resurrectionists, 89

Retirement from the University of Pennsylvania, Dr. Agnew's, 318-338

Rev. David C. A. Agnew, 3

Elias R. Beadle, 286

Francis Latta, 39, 40

John I[olmes Agnew, 41, 126

John S. MacIntosh, 288

Matthew Brown, to

Reyburn, Dr. Robert, 224, 235

Richard de Clare, 3

Robert Agnew, Dr. Agnew's father, 25, 26 description of, 26,27

Robert and Antoine Agneaux, 4

Robert Bruce, 7

Robert III, 9

Royal descent of the Agnews, 11

Rush, Benjamin, 355

Sabbath, Dr. Agnew's observance of the, 126,257

Saint-Lo, city of, 2

Samuel Annew, 21

"Sapientia cum latitia," 272

Satterlee Genera! Hospital, 131, 133

Saturday-Night Club, 273

Savre, Dr. Lewis A., address by, 308

School, Viennese, 355

School of Anatomy, 52, 7t, 116 of Medicine, 96

of Operative Surgery, 84,92

Scotels branch of Agnew family, 5, 8

Scots of Galloway, 8

Sermons, memorial, 351, 352

Services agamst the infidels, 4

Sheriff of Galloway, 5,18 of Wiutown, $5,8,9,16$

Sickness of Dr. D. Haves Agnew, 339

Signatures, Law of, 354

"Similia Similibus Curantur," 354

"Sinister hand of Ulster." 6

Sir Andrew Agnew, 126

Sir Andrew $\Lambda$ nnew, a famous soldier, 11, 18 "broad lints" of, 15 camp-story in reference to, 14 favorite Galloway story of 11 his prejudice against the French, 15 incidents of, described by Sir Walter Seott, 12

Sir Andrew Agnew, Bart, M.P., 10, 18

Sir Andrew Noel Agnew, 19

Sir Fulke l'Agneaux, 4

Sir John d'Agneaux, 4

Sir Philip d'Agneaux, 4
Sir William d'Agneanx, 4

Sir I'atrick Agnew, 18 descendants of 18

Sir William Douglas, 9

slavery, the subject of, 52 address on, by Dr. Agnew, 129

Sinith dunew, 2:3

Social life, relation of to surgical disease, $207-219$

Song, written l,y J. H. Arlains, 315, 316

music to, liy Hugh A. Clarke, 316

"Southern Agnews," "21

Southern sturients, 91, 129

Specialties, 360

Speech on abolition of slavery, 129

Ste. Marie d'Agneaux, it

Stillé. Dr. Alfred, portrait of, 315

Library, damaged during fire at University, 5:;

Story, favorite Galloway, 11

"Strong Bow," 3

"Summer Association," 97

brilliant teachers and writers, 100

Surgeon of Volunteers, Dr. Agnew, 131

Surgeons, distinguished, fifty y'ears ago, 4740

“Surgeons' House," 256

Surgery, lleerling in, 358

chloroform in, 357

ether in, 28:i, 357

laudanum in, 358

Surgery, Clinical Chair of, 139

Dr. Agnew's origrinal work in, 173

position in, 353-361

John Rhea Barton Professorship of, $1+1$

“Principles and Practice of," 160, 281

translater into .Jananese, 163

Surgical Club, Sorial, 270

Surgical lisease, relation of social life to, $207-219$

operations before introduction of anesthesia, 17

Thayer, Judge M. Russell, 337

Thursday-Evening ('lub, 270

'Tractors, Perlin's, 354

Tradition, family, 3,8

Translation of "Virgil" into French in 1582,4

Ulster, baronets of, 17

conquest of 6

lords of, 7

sinister hand of, 6

Union Trust Complany, Dr. Agnew a Director of, 27.1

University of 'ennsylvania, 42, 47, 52, 108, 137,151

Alumni Society of, 275

clinical instruetion at the, 139-142 
University of Pennsylvania, Dr. Agnew at War of 1812,32 the, 13 is

atcliess on retirement from, 331

last dilactic lecture at, $821-331$

retirement from the, $315-335$

Dr. Leedy at the, $7 \&, 137$

faculty of mediche at, $13,47,137,156$, 20

descrution of $43-15$

hospital of, insugurated by Governor Hartranft, 15t

removal to West Philadel hia, 151

Talerlictory aldress, $116-126$

of the Rebellion, 128

Warburton Anatomy B Bll, 90

Washington to Elberon, 231

Westey's last hymn, 263

West Laurel Hill C'emetery, mausoleum at,

Wigtown, 5, 21

Sheriti of $5,8,9,16$

William the Conqueror, 3,6

Wills' Eve Ilospital, 107, 142

Wimimili Street School, London, 76, 303

Wistar and Horner Museum, 332

Wistar Asworiation, 2-9?

Varions ways of slelling the name of $\mathrm{Ag}$ new, 1

Tenture in hu-iness, Dr. Agnew's, 60

Tiennes: show, 355

Voltaire, 121

Volunterer, Dr. Agnew surgeon of, 131

Wales, Surcmon-Genral, 221, 200

Wallace Mary A., 29 , 69

War, Civil, 42, 91, 100, 113,131

Wistar, Dr. Thomas, ode l, 312 Parties, $27: ;$

Women's Aferlical College, 1 tt

Woolwarl, sureen J. J., 22t, 233, 235

Wonds, cranial and heart, medico-legal aspects of, $197-206$

Writings, Dr. Agnew's, 113-116, 193

"Wynârift," 251

Xenophon, 117 




\section{UNIVERSITY OF CALIFORNIA LIBRARY}

Los Angeles

This book is DUE on the last date stamped below.

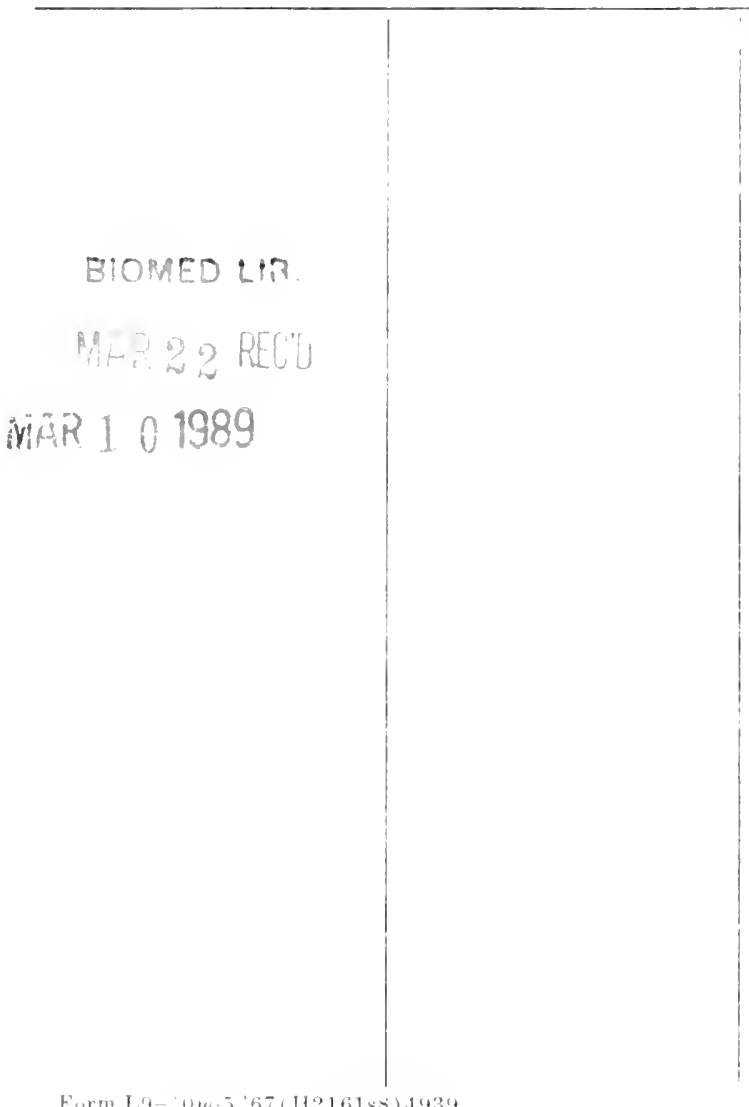

Furm Lo- 1) 5,57 (112161s4) 493! 


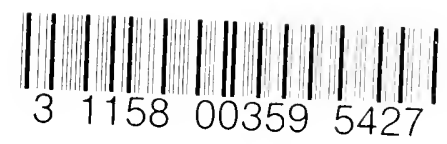




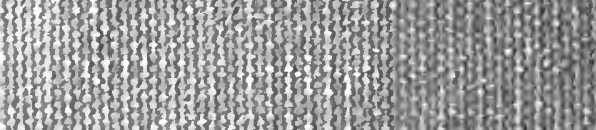

mit

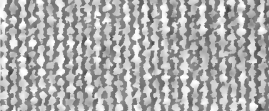

H.

W

ํํำ

W

W.

H.m.

min

mom

m.t.m

z.t.

m.t.

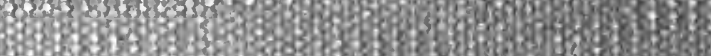

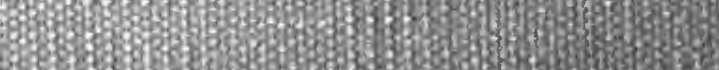

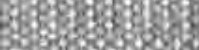

3 3.

3.

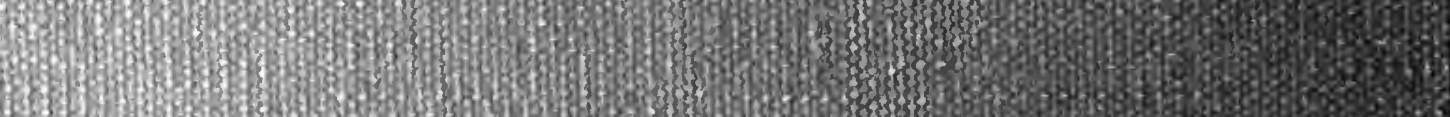
3.

33 3.

H.

H. \{

(3) 3 III 3.5. III) 